\title{
The Need for Competition in International Securities Regulation
}

\author{
Roberta Romano*
}

\begin{abstract}
This paper advocates opening up international securities regulation to greater regulatory competition than the scant competition that exists at present. After sketching the contours of an international regime of regulatory competition in securities laws and the reasons why such competition is desirable, the paper provides a detailed response to objections that have been raised to a proposal for a competitive securities regime that was principally focused on the United States, objections that would accordingly also be raised against this paper's proposal. These include whether the U.S. securities regime is directed at mitigating problems regarding disclosure of interfirm externalities and whether international competition will result in a regulatory race to the lowest level of disclosure. Because the analysis in support of regulatory competition in securities law draws upon the learning regarding competition across U.S. states over the production of corporate law, which has been successful in creating a regime that, on balance, benefits shareholders, the paper concludes by demonstrating that recent critiques of the efficacy of statecharter competition are unfounded.
\end{abstract}

\section{INTRODUCTION}

Although there is a significant international regulatory regime for banking institutions, ${ }^{1}$ there has been no successful effort at international harmonization of the regulation of securities transactions. This paper contends that the absence of a uniform international regulatory scheme is, however, a benefit for investors in securities because it allows for some competition among securities regimes. Moreover, elaborating on a position that I have previously advocated with respect to U.S. securities laws, ${ }^{2}$ the paper maintains that international securities

* Yale Law School and National Bureau of Economic Research. This paper was prepared for the Cegla Institute for Comparative and Private International Law of the Tel Aviv University Law School Conference on Protecting Investors in a Global Economy, June 27-28, 2000. I would like to thank Yakov Amihud, Ian Ayres, Stephen Choi, Robert Daines, Allen Ferrell, Henry Hansmann, Marcel Kahan, Ehud Kamar, Michael Klausner, Jonathan Macey, Paul Mahoney, and participants at the Conference for comments on earlier drafts and in conversation.

${ }^{1}$ The regime, established in 1988 under the auspices of the Bank for International Settlements and known as the Basle Accord, fixed capital requirements for international banks based on a formu laic treatment of credit risk. For one of the many articles assessing the efficacy of the Accord, see John D. Wagster, Impact of the 1988 Basle Accord on International Banks, 51 J. Fin. 1321 (1996). The regime has been subsequently amended to include in the required level of capital an adjustment for market risk. Bank for Int'l Settlements, Amendment to the Capital Accord to Incorporate Market Risks (1996), available at http://www.bis.org/publ/bcbs23.pdf.

${ }^{2}$ Roberta Romano, Empowering Investors: A Market Approach to Securities Regulation, 107 Yale L.J. 2359 
regulation should be opened up to even greater regulatory competition than the scant competition that exists at present.

The contention that competition in securities regulation would be for the better has been questioned by some commentators. ${ }^{3}$ This paper responds to those commentators. Notwithstanding assertions, there is no evidence supporting the claim that competition would result in a race to the bottom, with issuers choosing the lowest level of disclosure possible. Indeed, there is uncontroverted data to the contrary, that issuers subject to choice frequently disclose more information than required. In addition, there is an absence of evidence in support of the rationale for a single national regulator offered by some opponents of competition, that the content of the disclosure mandated by the single regulator regime in the United States includes significant interfirm externalities.

The paper proceeds by sketching the contours of an international regime of regulatory competition in securities laws and the arguments why such competition is desirable for investors, an analysis that I have made in greater detail in the context of recommending that the U.S. securities regulator, the Securities and Exchange Commission ("SEC"), should be exposed to competition in a significant domain of its activities - the regulation of issuers of securities. ${ }^{4}$ The paper then rebuts the objections that have been raised to that proposal. Because the analysis in support of regulatory competition in securities law draws upon the learning regarding competition across U.S. states over the production of corporate law —-which has been remarkably successful in creating a regime that, on balance, benefits shareholders - the paper concludes by demonstrating that recent critiques of the efficacy of state-charter competition are unfounded.

\section{The Desirability OF COMPETITION In INTERNATIONAL SECURITIES Regulation}

Most people, and not simply economists, find the statement that consumers are protected from producer exploitation by competitive product markets prosaic and intuitively obvious. But a number of legal commentators blanch at the suggestion of applying this wisdom to securities regulation. Upon analysis, however, the analogy is entirely apt. In today's global financial markets, which are dominated by sophisticated institutional investors, competition among securities regulators would not only protect investors, both large and small, but also would provide a superior regulatory regime.

\section{A. Regulatory Competition in International Capital Markets}

(1998).

${ }^{3}$ See, e.g., Merritt B. Fox, Retaining Mandatory Securities Disclosure: Why Issuer Choice Is Not Investor Empowerment, 85 Va. L. Rev. 1335 (1999); James D. Cox, Regulatory Duopoly in U.S. Securities Markets, 99 Colum. L. Rev. 1200 (1999). 


\section{The Need for Competition in Securities Regulation}

In competitive capital markets, issuers of securities have incentives to select regulatory regimes that protect investors from exploitation by insiders, because such choices lower the cost of capital. Even though individual investors may be poorly informed regarding what level of disclosure or other protective mechanisms are necessary, because the distribution of equity returns is pro-rated by share ownership and there is one price for shares, informed institutional investors dictate the regulatory choices of issuers and less-informed investors are thereby also protected. ${ }^{5}$ There is no realistic conflict between the informational requirements of institutional and individual investors. Institutional investors rely on public information ${ }^{6}$ and prefer its disclosure. For example, in the private debt market, in which the SEC permits lower disclosure because it is restricted to sophisticated (institutional and wealthy individual) investors, such investors demand disclosure of approximately the same information as is required to be disclosed in the public debt market. ${ }^{7}$ Similarly, in the European equity issues market, the level of disclosure for international-style offerings whose purchase is limited to institutional investors is higher than the disclosure required by European countries. ${ }^{8}$

In the context of sophisticated consumers of securities regimes, providing issuers with a choice of regulatory regimes - a market - is a mechanism superior to a single regulator or a regulatory cartel of internationally harmonized regimes for ascertaining what information disclosure is in investors' interests (i.e., the information that satisfies a cost-benefit calculation). This is because there will be a net flow of capital to firms operating under the regimes investors prefer and, hence, a feedback mechanism for regulators to ascertain which rules are cost effective. This input is especially important in the international regulatory setting because there are plausible reasons for concern that the product of international negotiations over regulatory cooperation will be even less responsive to investor interests than domestic legislation: as Paul Stephan notes, international lawmakers do not stand for election and hence are more susceptible to rent-seeking because they are subject to less political discipline compared to national legislators. ${ }^{9}$ While Stephan's examples are the international agreements and model laws drafted by international organizations that he considers "private legislatures," whose nation-state members

\footnotetext{
${ }^{4}$ Romano, supra note 2 .

${ }^{5}$ To the extent that there might be segregated investor markets for certain small stocks, individual investors would be protected by a disclosure requirement regarding the issuer's domicile's regime as discussed at infra text accompanying notes 36-39.

${ }^{6}$ The best evidence that institutional investors do not trade on private information is their inability to outperform the stock market. See, e.g., Stephen A. Ross et al., Corporate Finance 330 (5th ed. 1999).

${ }^{7}$ See, e.g., Luis F. Moreno Trevino, Access to U.S. Capital Markets for Foreign Issuers: Rule 144A Private Placements, 16 Hous. J. Int'1 L. 159, 195 (1993).

${ }^{8}$ See Howell Jackson \& Eric Pan, Regulatory Competition in International Securities Markets: Evidence from Europe in 1999, 56 Bus. Law. 653, 684-85 (2001).

${ }^{9}$ Paul B. Stephan, Regulatory Cooperation and Competition: The Search for Virtue (University of Va. Sch. of
} 
send representatives to periodic conferences to review and approve the work of task forces, and of other international bureaucracies that have adjudicative functions, ${ }^{10}$ the international regulatory organizations associated with securities law-IOSCO (the International Organization of Securities Commissions) and IASC (the International Accounting Standards Committee)—have similar features. Neither is comprised of elected officials of the nations they represent, and any uniform rules or harmonization schemes they devise are not typically presented to national legislatures for approval.

Present-day international securities regulation, however, offers firms only a limited choice of regime. Regulation follows the location where the securities trade. This jurisdictional rule does provide some firms with some choice: the regulatory regime for the many Israeli high-technology firms that have chosen to list on the New York Stock Exchange (NYSE), for instance, is that of the United States, administered by a U.S. government agency, the SEC, rather than an Israeli government agency. It is not obvious whether these firms list on the NYSE precisely to obtain the U.S. regulatory regime as a means of quality commitment to investors ${ }^{11}$ or whether the U.S. regime is simply a cost borne in order to access the deeper U.S. capital market and, in particular, to obtain coverage by U.S. financial analysts, a group far more numerous than the Israeli analyst population and with considerably more exposure to technology stocks, which produces improved investor information about the firms. ${ }^{12}$ But an Israeli firm cannot trade in the U.S. and remain subject solely to the Israeli regulatory schema; it automatically is subject to the U.S. regime upon listing on a U.S. exchange.

Furthermore, the choice to come under U.S. law is a one-way street: U.S. firms cannot opt for non-U.S.

Law Working Paper No. 99-12, 1999).

${ }^{10}$ In separate articles, he elaborates this point by reference to specific examples of such organizations. Paul B. Stephan, The Futility of Unification and Harmonization in International Commercial Law, 39 Va. J. Int'1 L. 743, 753-57 (1999) (discussing examples of international private legislatures, such as the Hague Conference on Private International Law and the United Nations Commission on International Trade Law); Paul B. Stephan, Accountability and International Lawmaking: Rules, Rents and Legitimacy, 17 Nw. J. Int'1 L. \& Bus. 681, 684-85 (1996-1997) (discussing examples of international adjudicative bureaucratic bodies, such as the International Monetary Fund and World Trade Organization).

${ }^{11}$ See, e.g., Oren Fuerst, A Game Theoretic Analysis of the Investor Protection Regulations Argument for Global Listing of Stocks (1998) (unpublished working paper) (providing bonding argument for issuer choice of exchange listing); Edward B. Rock, Securities Regulation as a Lobster Trap: A Credible Commitment Theory of Mandatory Disclosure (1999) (unpublished working paper) (providing bonding explanation for securities regulation). Israeli firms listing in the United States did not also list on the Tel Aviv Stock Exchange because they did not want to comply with two sets of disclosure requirements. See William A. Orme, Jr., Israelis Ask if Their Exchange Is an Endangered Species, N.Y. Times, Feb. 29, 2000, at C4. This requirement was recently removed, see infra note 34. Because the Israeli regime entails stricter disclosure than the U.S. regime on some dimensions, id., the bonding rationale for a U.S. listing by Israeli firms, see Fuerst, supra, Rock, supra, is an open question.

${ }^{12}$ See, e.g., Eli Amir et al., What Value Analysts? 3 (Paine Webber Working Paper Series No. PW-99-12, Nov. 1999) (examining analysts' earnings forecasts over 1982-1997 for a total of over 18,000 firm/year observations, they find contribution of financial analysts to equity valuation is largest in high-tech industries), available at http://www.columbia.edu/cu/business/wp/99/pw-99-12.htm 
coverage. That is, a U.S. firm is unable to sidestep the authority of the SEC by listing on the Tel Aviv exchange and selling those shares to U.S. investors, for example, because a firm with a substantial U.S. presence (as measured by business activity and investor residence) is subject to U.S. securities law no matter where its securities are purchased. ${ }^{13}$ As U.S. firms and U.S. investors comprise a large proportion of the international capital market, regulatory competition is thus severely circumscribed.

To create a truly competitive regime of securities regulation, present restrictions on regime choice must be removed. This requires that issuers and investors be able to choose their regulators independent of firm or investor residence or securities transaction location, that is, independent from where they are raising capital. The central proposition is this: only when parties to a securities transaction are able to select their regulatory regime without restriction will government authorities be subject to meaningful competitive pressure. This is because in such circumstances, if firms and investors find a particular regulatory regime burdensome, they can select another one without undoing their financing choice.

\section{The Benefits of Establishing Regulatory Competition}

Regulatory competition subjects government agencies to fluctuating inflows and outflows of regulated entities as firms transfer their activities to come under the jurisdiction of the regulator whose regime they prefer. Such competition is desirable because it reduces the possibility that a regulator will be able to transfer wealth across different regulated entities or redistribute wealth from the regulated sector to preferred individuals or organizations. ${ }^{14}$ The U.S. securities regime, for instance, has historically transferred wealth across constituents, the most notable example being the SEC's longstanding acceptance of fixed commission rates, which benefited individual investors and exchange members at the expense of institutional investors. ${ }^{15}$ Firms' ability to engage in regulatory arbitrage and switch regulators to a lower cost regime in a competitive regulatory environment restricts regulators' ability to engage in such implicit taxation.

Regulatory competition also more quickly corrects for policy mistakes than a single regulator can,

${ }^{13}$ See, e.g., Merritt B. Fox, Securities Disclosure in a Globalizing Market: Who Should Regulate Whom?, 95 Mich. L. Rev. 2498, 2610-11 (1997) (discussing the current U.S. approach in which U.S. jurisdiction is triggered by sale of securities in United States or by status as a U.S. issuer). It cannot be doubted that the SEC would assert jurisdiction over a foreign-exchange-listed domestically-incorporated firm with a substantial number of U.S. investors, despite its current emphasis on U.S. markets over U.S. investors in conceptualizing its transactional jurisdiction. See, e.g., Stephen J. Choi \& Andrew T. Guzman, The Dangerous Extraterritoriality of American Securities Law, 17 Nw. J. Int'l L. \& Bus. 207, 221 (1997) (criticizing long-standing extraterritorial reach of U.S. securities law and noting SEC's announced shift in basis for jurisdiction, from domestic investors to markets, when promulgating Regulation $\mathrm{S}$ relating to offshore public offerings).

${ }^{14}$ See, e.g., Edward Kane, De Jure Interstate Banking: Why Only Now, 28 J. Money, Credit \& Banking 141 (1996). 
because in a competitive market, there is a built-in self-correcting mechanism, as the actions of numerous actors aggregate information efficiently. Namely, the flow of firms and investors into and out of particular regulatory regimes provides information concerning which rules are thought to be more desirable by investors; this is an instance of the concept from consumer demand theory referred to as "revealed preference."16 When two products are both available for purchase (that is, affordable) to a consumer, the consumer's choice is an indication that the utility she obtains from the selected product is greater than what she would have obtained from the product that was not selected: observed choices are evidence of unobservable preferences. The transaction flows provide a feedback mechanism to regulators regarding the efficacy of their regime; under the plausible assumption that regulators prefer to have within their jurisdiction more rather than fewer regulated firms and transactions, ${ }^{17}$ when a regulator finds that its jurisdiction is subject to a net outflow, it will reassess its regulatory regime so as to stem the decline in its jurisdictional sphere. Where the choice of regime is bundled with the source of capital, in contrast, the signal regulators receive from transaction flows regarding the desirability of their legal regimes is much more attenuated, because issuing firms must trade off the adequacy of the regimes against access to capital.

In addition, regulatory competition can be expected to foster innovation, since the feedback mechanism of interjurisdictional flows that reduces the possibility of regulatory error also provides an incentive for regulators to improve their regimes. ${ }^{18}$ Further feeding back into that process, when the choice of jurisdiction is restricted to products meeting particular criteria, regulated firms have incentives to devise new products to come under the preferred regulator. In the United States, for instance, wherever there has been regulatory competition, there has been significant innovation in products, ${ }^{19}$ institutional practices, ${ }^{20}$ and in legal rules. ${ }^{21}$ Indeed, the SEC has

\footnotetext{
${ }^{15}$ See Susan M. Phillips \& J. Richard Zecher, The SEC and the Public Interest 72, 88-89 (1981).

${ }^{16}$ For a technical discussion of the theory of revealed preference, see Marcel K. Richter, Revealed Preference Theory, in 4 The New Palgrave: A Dictionary of Economics 167 (John Eatwell et al. eds., 1987).

${ }^{17}$ For the classic theoretical contribution on regulatory behavior that makes such an assumption, see William A. Niskanen, Jr., Bureaucracy and Representative Government 38-41 (1971).

${ }^{18}$ Susan Rose-Ackerman develops a model in which local governments may not innovate because they cannot capture the benefits of an innovation as other governments can freely copy it (legal reforms are not patentable). In her model, risk-averse local politicians, to ensure their reelection with risk-averse voters, therefore do not take on the risk of innovation. Susan Rose-Ackerman, Risk Taking and Reelection: Does Federalism Promote Innovation?, 9 J. Legal Stud. 593 (1980). Although one condition that decreases politicians' incentives to innovate in her model, restricted mobility of voters, is not present in charter competition and would not be present in securities regulation competition, since corporations are far more mobile than voters because a domicile change entails solely a paper filing and no physical relocation, even if the model was fully applicable, Rose-Ackerman does not maintain that a single government would innovate more than multiple governments. Rather, she suggests that a national government might adopt programs to encourage innovation by local governments (such as through subsidies to innovators) and notes that the same political incentives dulling risk-taking will be present at both government levels, as the same citizens elect both sets of officials. Id. at 615-16.

${ }^{19}$ For instance, much of the extraordinary growth in financial derivatives can be attributed to the competitive
} 
eliminated specific disclosure requirements for issuers where it has encountered competition-foreign equity issues and domestic debt issues (the Eurobond market)—but not where it has exclusive jurisdiction—domestic equity issues. ${ }^{22}$

Finally, if there are significant differences in firm characteristics such that the most suitable regulatory regime differs considerably across firms, then when firms and investors can choose their regulatory regime, they can self-select the more appropriate regulatory schema. ${ }^{23}$ There are alternatives to competition to achieve regulatory diversity: although securities regimes today consist of mandatory rules, which offer no appreciable diversity for public issuers, a shift to an enabling regime could have the effect of firms opting out of the default regime and result in regulatory diversity.

Jurisdictional competition would, however, be preferable to a single regulator with an enabling regime. First, it could reduce issuer transaction costs. If significant diversity in regulation were desirable, there would be many firms opting out of the single regulator's default regime. With multiple regulators, each could offer a different regulatory package and firms could adopt one of those packages rather than have to craft their own. ${ }^{24}$

regulatory regime. See, e.g., Edward Kane, Regulatory Structure in Futures Markets: Jurisdictional Competition between the SEC, the CFTC, and Other Agencies, 4 J. Futures Markets 367, 380 (1984); Merton H. Miller, Merton Miller on Derivatives 52-53 (1997); Roberta Romano, The Political Dynamics of Derivative Securities Regulation, 14 Yale J. Reg. 279, 370, 382-83 (1997).

${ }^{20}$ See, e.g., Paul H. Kupiec \& A. Patricia White, Regulatory Competition and the Efficiency of Alternative Derivative Product Margining Systems (Board of Governors of the Fed. Reserve Sys., Finance \& Econ. Discussion Ser. No. 96-11, June 11, 1996) (describing the impact of regulatory and market competition on development of an optimal margining system for options).

${ }^{21}$ In the competition for corporate charters among U.S. states, Delaware, the leading incorporation state, engages in significant, and continual, legal innovation. See, e.g., Roberta Romano, Law as a Product: Some Pieces of the Incorporation Puzzle, 1 J.L. Econ. \& Org. 225, 240 (1985).

${ }^{22}$ Roberta Romano, The Genius of American Corporate Law 97 (1993). For a detailed discussion of this trend and a proposal advocating that the SEC use its exemptive power to make the disclosure regime for new domestic issues optional, see Alan R. Palmiter, Toward Disclosure Choice in Securities Offerings, 1999 Colum. Bus. L. Rev. 1. Palmiter advocates an SEC exemptive approach because he does not believe that states will offer effective disclosure regimes given past experience with state securities regulation and corporate law's use of ex post liability for fiduciary duty violations rather than ex ante disclosure requirements. Id. at 107. Because prior experience with state securities regimes did not occur under a competitive regime due to a non-domicile-based choice-of-law rule, there is no reason to assume, as does Palmiter, that the states will be incompetent in competing for securities registrations. In addition, it is difficult to draw conclusions from corporate law's emphasis on ex post liability over ex ante disclosure, because the federal disclosure regime preempted state action on that front. Of course, competitive federalism does not guarantee any state's regulatory success: if states are ineffectual competitors compared to the SEC, then federal registrations will predominate.

${ }^{23}$ For an analysis favoring regulatory competition because of firms' need for diversity in regimes, see Stephen J. Choi \& Andrew T. Guzman, Portable Reciprocity: Rethinking the International Reach of Securities Regulation, 81 S. Cal. L. Rev. 903 (1998).

${ }^{24}$ One critic of the need for diversity in securities regimes defends his position by means of an example with two countries, in which he does not obtain the desired diversity in regimes, by manipulating the number of firms desiring particular rules in the two countries. Fox, supra note 3 . With more than two regulators, this claim is 
This is not a determinative consideration, however, in that the single regulator could offer a menu of default regimes from which issuers could choose, and in such a scenario, transaction costs might not be appreciably higher. Second, if the optimal regulatory mix consists of some mandatory and some enabling components, a single regulator would have greater difficulty ascertaining the optimal mix compared to a competitive regime, in which issuer choice across regime packages provides a ready and reliable source of information concerning investor preferences. ${ }^{25}$ Again, a single regulator adopting a menu of regimes could achieve diversity of regime choice. But it is doubtful that a single regulator following a menu approach would be subject to the same feedback mechanism of firm inflows and outflows that facilitates identification of the desirable amount of regime diversity by competing sovereigns. Namely, since all firms would be under the single regulator's jurisdiction regardless of the number of choices it offers, the single regulator would have less of an incentive to be as responsive to changing business conditions in devising alternative regime choices and updating its menu than would have competing regulators, who can increase the number of regulated entities under their jurisdictional reach by innovation.

The potential need for regulatory diversity as a justification for facilitating securities regulation competition, as is true of most arguments in support of competition, is also an argument against regulators' topdown efforts to effect international regulatory harmonization. ${ }^{26}$ In fact, if substantial regulatory diversity is not preferred by issuers and investors, then competition will produce uniform regulatory outcomes without a need for governmental agreements mandating harmonization. In the United States, for instance, there is considerable uniformity across state corporate law, notwithstanding the competition for corporate charters. ${ }^{27}$

It should further be noted that the proposal for regulatory competition should assist the development of

problematic, because a smaller number of firms will be sufficient to support a regulatory regime. Even if there were significant network effects in securities regulation to justify a two-country example, networks serving speciality or niche-markets need not be disadvantaged by a small number of users (i.e., by network effects) to sustain product use. See Stan J. Leibowitz \& Stephen E. Margolis, Network Effects and Externalities, in 2 The New Palgrave Dictionary of Economics and the Law 671, 673 (Peter Newman ed., 1998). For a discussion of network effects, see infra Part IV.C.

${ }^{25}$ It should be noted that while Lucian Bebchuk suggests that there must be a single federal regulator to have mandatory rules, see Lucian Arye Bebchuk, Federalism and the Corporation: The Desirable Limits on State Competition in Corporate Law, 105 Harv. L. Rev. 1435 (1992), there are, in fact, mandatory rules in corporation codes that are subject to state competition, such as the liability of directors and officers for breach of the duty of loyalty. However, as I have maintained in greater detail elsewhere, these rules are only mandatory in the sense that if investors did not desire the presence of such rules, they would not be in the codes, that is, they are non-binding constraints. Roberta Romano, Answering the Wrong Question: The Tenuous Case for Mandatory Corporate Laws, 89 Colum. L. Rev. 1599, 1601 (1989).

${ }^{26}$ For the development of such an argument in the private (corporate and commercial) law context, see Uriel Procaccia \& Uzi Segal, Thou Shalt Not Sow Thy Vineyard With Divers Seeds? The Case Against the Harmonization of Private Law (2000), at www.econ-pol.unisi.it/scdbanc/CONFERENZA/FILE_PDF/12-Procaccia.pdf.

${ }^{27}$ See, e.g., William J. Carney, The Production of Corporate Law, 71 S. Cal. L. Rev. 715, 729-34 (1998); Romano, supra note 22, at 47. 
capital markets in small emerging-market nations that do not have the requisite resources to engage in effective securities regulation: their domestic corporations will be able to subject themselves to a developed nation's regime. The potential to so benefit is not purely speculative. Some scholars have contended that differences in the securities regimes between Poland and the Czech Republic led to significant financing difficulties for Czech issuers and the contraction of its capital market, as well as losses to investors. ${ }^{28}$ Had corporations in the Czech Republic been able to select their securities domicile, this problem would have been mitigated, for they would have been able to select a more stringent regime and thereby raise capital more effectively, because investors would have been able to infer firm quality (here, propensity for self-dealing by management) by the domicile choice. An increase in registrants from emerging markets would, no doubt, place an additional burden on developed nations' regulators, as the emerging market issuers would be registering with a regulator without necessarily listing on a market within the regulator's geographic borders. Higher registration fees could be charged such registrants to defray the increased regulatory cost. In addition, private enforcement of compliance with securities laws could also absorb some of the potential regulatory burden.

\section{Feasibility of International Competition}

It is not possible, however, to establish a fully competitive international regime without multilateral government action. Nations must agree to alter their present territorial jurisdictional approach to securities regulation and recognize instead a statutory securities domicile, as selected by an issuer. Although regulatory agencies enter into cooperative agreements, such as the SEC's numerous memoranda of understanding with foreign regulators concerning the sharing of information and enforcement operations ${ }^{29}$ or the Basle Accord on capital requirements signed by central banks, ceding a territorial jurisdictional rule is not a matter that is unambiguously within an agency's purview. In the United States, for example, such rules are legislative or judicial in origin. Mutual recognition of statutory securities domicile would therefore have to be effectuated by a treaty or other executive agreement approved at a higher governmental level than the securities agency. This undoubtedly complicates the implementation of a competitive international regime.

There are avenues for circumventing implementation of a statutory domicile, and, hence regulatory competition at the treaty-level, by agency-level action, such as the SEC's recent proposal to consider permitting

\footnotetext{
${ }^{28}$ See, e.g., Edward Glaeser et al., Coase Versus the Coasians, 116 Q.J. Econ. (forthcoming 2001).

${ }^{29}$ See, e.g., SEC, Memorandum of Understanding with the Government of Switzerland, 1982 SEC LEXIS 2631
} (Aug. 31, 1982) (insider trading law enforcement cooperation agreement); Canada-United States: Memorandum of Understanding on Administration and Enforcement of Securities Laws, 27 I.L.M. 410 (1988) (MOU between SEC and Ontario, Quebec, and British Columbia Securities Commissions on cooperation in enforcement matters). 
foreign firms to list on U.S. exchanges without complying with U.S. accounting standards. ${ }^{30}$ The SEC could, in fact, unilaterally implement a competitive system for U.S.-listed securities under its general exemptive authority, which permits it to "unconditionally exempt any person, security or transaction, or any class or classes of persons, securities, or transactions, from any provision or provisions" of the securities laws.31 But such action would not seem to be in the realm of the politically probable: with the notable exception of the Civil Aeronautics Board, which enthusiastically put itself out of business when it deregulated the airline industry in the 1970s, federal government agencies have not voluntarily abandoned their regulatory domain and the SEC's past behavior is no exception to that general rule. It has consistently sought to expand its authority over equity derivatives, 32 and its new proposal considering relieving foreign firms from following U.S. accounting standards would actually expand its jurisdiction by attracting more foreign listings onto U.S. exchanges. Moreover, that release contained not even a hint that it would ever reconsider the accounting standards applicable to domestic firms, and it has only increased, not decreased, the ongoing disclosure requirements for those firms. The discretionary power of nonU.S. regulators to implement regulatory competition without a treaty is undoubtedly more limited than that of the SEC. European Union regulators, for example, must recognize Member States' firms trading in their jurisdictions under their home states' regime, but a series of directives has mandated minimum standards of harmonization

${ }^{30}$ See SEC Release No. 33-7801, 17 C.F.R. pts. 230, 240, 2000 SEC LEXIS 256. (Feb. 16, 2000). The firms will be permitted to comply with international accounting standards instead. It is not clear whether this proposal will be adopted. U.S. issuers are expected to object to competitors being permitted to follow cheaper accounting standards, and other opponents fear that it will lead to a weakening in U.S. accounting standards, as domestic firms lobby to be subject to the same lower standard as foreign listings. The SEC had long opposed any substitution of international for U.S. accounting standards; the change expressed in the release is most likely a result of the recent decision to change the organization of the entity determining international accounting standards, the International Accounting Standards Committee (IASC), in which the SEC expects to exert greater influence over decision-making. The approach in this release stands in contrast to the more limited reach of the SEC's heretofore broadest mutual recognition agreement, the Multijurisdictional Disclosure System accord it signed with Canadian securities regulators, which permits Canadian firms to list in the United States while complying solely with Canadian disclosure rules, but mandates the reconciliation of their financial statements with U.S. accounting standards. Multijurisdictional Disclosure and Modifications to the Current Registration and Reporting System for Canadian Issuers, Exchange Act Release No. 6902, 56 Fed. Reg. 30,036 (July 1, 1991).

${ }^{31}$ Securities Exchange Act of 1934, § 36, 15 U.S.C. $§ 78 \mathrm{~mm}$ (2001) and Securities Act of 1933, § 28, 15 U.S.C. § 77z-3 (2001); see Palmiter, supra note 22, at 89-91 (advocating that the SEC should, and could, use its statutory exemptive authority to permit corporations to select their own disclosure schemes for new issues, but not extending his proposal to ongoing disclosures). Congress imposed only one constraint on the use of that authority, that no exceptions could be made regarding the regulations applicable to government securities brokers and dealers, see 15 U.S.C. $\S 78 \mathrm{~mm}($ b), a limitation not relevant to competitive securities regulation for private issuers. Otherwise, the agency has the sole discretion to issue exemptions that are "necessary or appropriate in the public interest," and "consistent with the protection of investors," 15 U.S.C. $\S \S 77 \mathrm{z}-3,78 \mathrm{~mm}(\mathrm{a})(1)$, criteria that the proposed regime of securities regulatory competition would easily satisfy.

${ }^{32}$ See Romano, supra note 19, at 354-369. 
across the EU, and mutual recognition does not extend to firms from non-EU nations. ${ }^{33}$ Non-U.S. regulators may also not wish to endorse a competitive approach, regardless of their statutory authority. In Israel, for instance, Israeli firms trading on U.S. exchanges did not cross-list on the Tel Aviv exchange in order to avoid having to comply with additional requirements of the domestic disclosure regime, because the Israeli Securities Agency did not provide an exemption for compliance with U.S. disclosure requirements. ${ }^{34}$ Hence, resort to action at the agency- rather than treaty-level is only a partial, less than ideal solution. As negotiating multilateral treaties on securities regulation may well be time-consuming, certain unilateral action could jumpstart the process. In particular, given the importance of the U.S. market, if Congress were to alter the jurisdictional rule for securities regulation to eliminate the SEC's monopoly over issuers and adopt a statutory domicile approach for all firms issuing public shares in the United States, this would be a significant step toward introducing competition in international securities regulation. An additional benefit from regulatory competition for U.S. firms, which is not relevant in many other nations, is that it would permit the integration of corporate and securities law, as a firm could select the same domicile for both regimes. ${ }^{35}$

In conclusion, it should be noted that a shift from the present system of territorially based jurisdiction to a statutory securities domicile regime, which is at the heart of the competitive approach to securities regulation, is not a farfetched proposal for international securities regulation, as it may initially appear. In the new world of electronic and Internet trading, territoriality is rapidly becoming an empty concept. Physically-located centralized securities exchanges are also on their way to becoming relics. The most well-known example of this phenomenon involves trading in futures on German government bonds: the creation of an electronic futures exchange in

\footnotetext{
${ }^{33}$ Council Directive 87/345, 1987 O.J. (L 185) 81 (directive requiring mutual recognition of a listing approved by any Member State's competent authority if the listing meets the EU's minimum standards for securities regulation); Council Directive 80/390, 1980 O.J. (L 100) 1 (directive setting forth minimum disclosure standards); Council Directive 79/279, 1979 O.J. (L 66) 21 (directive setting forth minimum requirements for exchange trading of a security).

${ }^{34}$ See Orme, supra note 11 . The Israeli legislature changed the law to permit such cross-listings in July 2000, and the regulatory authority issued implementing regulations in December 2000. See Amir N. Licht, Managerial Opportunism and Foreign Listing: Some Direct Evidence 15 (2001), at SSRN Electronic Paper Collection, http://papers.ssrn.com/paper.taf?abstract-id=256653. It appears that the push for this change to recognition of U.S. listings was not solely related to the Tel Aviv Stock Exchange's loss of high-technology firm listings but also to rebellion over the new national corporations law that led Israeli firms to reincorporate in Delaware; the new corporations law was also revised at the time of the securities law change. As might be expected, the Israeli Securities Agency was not the prime mover behind the diminution of its authority.

${ }^{35}$ For a discussion of the desirability of this possibility, see Romano, supra note 2, at 2409-10. International competition would have the opposite effect for firms in other nations that trade domestically in that it would permit them to select a foreign securities regulator when presently the same national sovereign regulates both the securities and corporate laws under which they operate. But foreign firms trading in the United States are in a position similar to that of U.S. issuers, in that competition will permit them to be under the same national sovereign for securities transactions as they are for corporate law.
} 
Frankfurt eliminated the longstanding dominant physical London market for the instrument, and as a result, the London futures exchange itself went electronic. Given such sweeping technological change, regulation by issuer domicile is more viable than regulation by trading location, as it will become far more problematic to identify a territorial location for a transaction.

\section{B. Investor Protection Concerns under International Competition}

To be sure, a non-territorially based securities regime may create new complications for investors. An investor purchasing a security listed on an exchange in his or her own state will no longer be assured that the home state's securities rules apply to the transaction and subsequent acts by the issuer. This uncertainty over the applicable regime raises three key issues: will investors be able to discern a security's regime (a premise of the effectiveness of regulatory competition); will they be able to enforce their legal rights under a non-domestic regime; and will they be exploited by insiders' changing securities regime midstream? To minimize these investor-protection concerns, two procedural requirements are proposed as preconditions for effective regulatory competition: disclosure of the relevant securities regime and investor approval of a change in securities regime. A third requirement, directed at local judiciaries rather than issuers, is also proposed: recognition of forum selection, including arbitration, clauses for the resolution of private securities lawsuits. These requirements would best be effected by inclusion in the multilateral treaties creating the international competitive regime.

\section{Disclosure of the Securities Regime}

To minimize any potential investor confusion concerning what regime governs a purchased security, in my proposal to inject competition into the U.S. regime, I advocated requiring disclosure of the applicable regime at the time of a security purchase, by the issuer in an initial public offering ("IPO") and by the broker in a secondary market transaction. ${ }^{36}$ This disclosure must make plain that the domestic civil and criminal liability regimes do not apply to the transaction. In the international setting, such a requirement should be included in the treaties establishing competition as a condition for mutual recognition, to be implemented, correspondingly, in each nation's conforming legislation. A domicile disclosure rule could, however, also be effectuated by exchanges as a listing requirement. Adopting such a policy would be advantageous for an exchange because by reducing the transaction costs of determining domicile, it would be of value to investors and thereby increase trading volume.

In addition to disclosing the securities domicile, if, in the remote event that a domicile has no issuer liability for fraud or no financial disclosure requirement, disclosure of these features of the regime's content

\footnotetext{
${ }^{36} I d$. at 2413-15. The requirement was to be effectuated as a condition to opt out of the federal regime in the
} 
should also be required at the time of purchase under the international agreements establishing regulatory competition. Disclosure of a regime's lack of capacity to prosecute issuers violating disclosure laws or otherwise engaging in fraud should be required as well. ${ }^{37}$ The disclosure requirement concerning a regime's content is limited to the notice of the thoroughly aberrant case of no fraud liability or no financial disclosure requirement in order to minimize the possibility of significant litigation over whether appropriate disclosures regarding a regime's content were made at the time of a securities transaction. The disclosure regarding the regime's capacity to prosecute violators is necessary to eliminate an obvious means of circumventing the content disclosure requirement: a regime with an antifraud provision that cannot be enforced is equivalent to a regime with no such provision.

It is inconceivable that a securities regime would have no liability for fraud or no financial disclosure requirement when investors have even a modicum of sophistication, as such individuals would not invest in securities under such circumstances (or they would pay a trivial sum for shares). More important, as no reputable issuer would register under such a regime, it would not be adopted in a nation with public or multinational corporations that desire domestic registrations. A deviant regime with regard to fraud and disclosure regulation would therefore be imaginable only in a small country catering to small firms with unscrupulous promoters targeting exclusively unsophisticated investors, that is, firms trading in a segmented equity market in which institutions do not participate. This hypothetical regime would be the international market analogue to penny stocks in the U.S. domestic setting. Promoters of this sort presumably would choose such a regime in order to defraud unsophisticated investors. In this regard, regime content disclosure under regulatory competition is a safeguard that is unnecessary for the vast majority of public stock issues, where markets are not bifurcated for institutional and individual investors.

The problem relating to antifraud protection under a regime of regulatory competition is limited to small firms whose equity is not purchased by institutions or sold in the regulating state, and whose promoters could thereby choose a regime facilitating fraud on the assumption that the targeted individual investors would be unaware $f$, or otherwise misperceive, the characteristics of the relevant securities regime. Two general approaches could be taken to mitigate this problem: mandatory disclosure of an investment's securities regime

federal legislation authorizing competition.

${ }^{37}$ No such disclosure requirements were contained in my proposal for introducing competitive federalism into U.S. securities regulation because their absence from any state securities regime is not in the realm of the probable. For example, all U.S. states have antifraud statutes, and competition will not alter this regime feature as no state competing for charters has eliminated the analogous type of misconduct in the corporate law setting-the duty of loyalty. It admittedly may be difficult to measure enforcement capacity; expenditures below a minimum level of resources allocated to government enforcement activity, adjusted for market size, number of listings, or population, are possible benchmarks. 
and the prohibition of specified (foreign-regulated) investments.

The protection of individual investors through the provision of information, a requirement of disclosure of the regime at the time of securities sales, follows the approach of U.S. securities regulation that disclosure, rather than product quality restriction, is the most appropriate mechanism for government intervention in capital market transactions. The notice investors receive when informed that their investments will be regulated by an obscure nation, particularly one with no rule against fraud or no resources allocated to enforce an antifraud law, should temper gullible individuals' purchases, which will reduce the profitability from offering and, hence, deter the emergence of deviant regimes catering to unscrupulous promoters. Moreover, under regulatory competition, only regulators whose regimes appeal to institutional investors will succeed in obtaining numerous registrants and thereby be engaged in issuer, as well as broker, regulation. Because many regulators will have a marginal role concerning issuers-none or very few firms will be registered with them--these regulators' efforts at individual investor protection will therefore necessarily be focused on broker, rather than issuer, regulation and, they can focus particularly on assuring that brokers comply with the disclosure rule regarding the features of the domicile of the securities that they are hawking.. This shift in regulatory focus would certainly be beneficial for small nations with limited regulatory resources. It should also aid unsophisticated investors by directing agency resources toward what is the more common source of such investors' losses, broker misconduct.38 The abuse in small stock offerings, for example, as Alan Palmiter notes, is by securities professionals, not issuers, evidenced by the fact that the SEC's enforcement initiative against small-stock fraud "focused on penny-stock brokers, not issuers." 39 There is no reason to assume that the situation would differ in the international securities setting. Required disclosure of the absence of rudimentary investor protections-liability for fraud and financial disclosure - should alert even unsophisticated individuals of the danger entailed in making an investment in a

\footnotetext{
${ }^{38}$ Although casebooks emphasize antifraud (insider trading and disclosure) cases, complaints against brokers are a more significant source of individual investor losses than the texts would suggest. The leading casebooks have at most one chapter on broker issues, and sometimes no coverage at all, e.g., Richard W. Jennings, Harold Marsh, Jr. \& John C. Coffee, Jr., Cases and Materials on Securities Regulation ( $7^{\text {th }}$ ed. 1992); David L. Ratner \& Thomas Lee Hazen, Cases and Materials on Securities Regulation ( $5^{\text {th }}$ ed. 1996); James D. Cox, Robert W. Hillman \& Donald C. Langevoort, Cases and Materials on Securities Regulation (2d ed. 1997). In contrast, the SEC allocates considerable enforcement time to broker misconduct, often more than it does on issuer misconduct. See,e.g, SEC 1998 Annual Report: Program Areas 1-6,10 (the vast majority of what the agency deemed "significant enforcement actions" for 1998 involved broker-dealer activities and not issuer disclosure or insider trading cases, and the over 50,000 investor complaints to which the agency responded, recovering over $\$ 1$ million, involved broker-dealer claims) (formerly also available at http://www.sec.gov/annrep98/ar98main.htm);SEC 1999 Annual Report 1-10, 140 (approximately half of what agency deemed "significant enforcement actions" for 1999 involved broker-dealer activities and not issuer disclosure or insider trading cases; by percentage broker-dealer cases were $20 \%$ and newsletter cases were $6 \%$ compared to $18 \%$ for issuer/financial statement cases and $11 \%$ for insider trading cases; securities offering cases which can involve both brokers and issuers were 24\%) (available at http//www.sec.gov/pdf/annrep99/ar99full.pdf).
} 
company subject to such a regime and deter unscrupulous promoters from preying on the unwary. Apart from prohibiting specified citizens' investment opportunities to, for example, domestic firms or firms domiciled in regimes with specific protections, a state cannot undertake more regulation in the case of a foreign issuer besides regime disclosure to protect unsophisticated investors without generating significant costs for the overwhelming majority of investors (who, it must be recalled, in the most developed public markets are institutions) and reputable firms, who have the capacity to select the most appropriate foreign regime. Even a senior SEC official has candidly acknowledged that there are limits to what the government can do to prevent investors from inappropriate trading (and this is, of course, investment under what is considered to be the most stringent securities regime in the world). In an interview, Laura Unger, an SEC commissioner who has been active in the agency's activities regarding online trading, was asked and responded:

Interviewer: "For example, let's say I'm signing up for an account with a brokerage firm, I don't have a job, and I want to trade away the only $\$ 5,000$ I have in the world-I can probably do that. Do you think I should be able to?"

Unger: "I do think you should be able to. I wish you wouldn't but the industry and the commission are not here to guarantee that everyone is going to make money in the stock market. ${ }^{, 40}$

Such reasoning is equally applicable in the context of trading in foreign securities. Indeed, quite apart from being ineffective, investor protection regulation beyond minimal regime disclosure could communicate to unsophisticated individuals the false impression that unscrupulous promoters have been eliminated from the market, creating perverse, unintended consequences of moral hazard, in which individuals adopt higher-risk investment strategies because they believe that the regulatory apparatus will protect them from possible loss.

Countries could restrict individuals' investment choices to securities registered in domiciles with minimum regime content or enforcement capacities, to protect the unsophisticated from unscrupulous promoters. There are two severe, and in my judgment fatal, problems with such an approach, compared to the regime disclosure requirement advocated here. First, there is a substantial danger that such an approach would become, in due course, a transnational regulatory regime with all the costs associated with such a regime. National policies that restrict citizens' investments to issuers registered under regimes with specified content are undesirable, in short, because they provide an avenue for regulators to undermine competition by specifying requirements that are not cost-effective for the investors whose preferences under competition direct issuers' choice of regime.

${ }^{39}$ Palmiter, supra note 22, at 37.

${ }^{40}$ Stacy Forster, The Cop: An SEC Commissioner Talks about the Challenges of Battling Online Fraud, Wall St. J., June 12, 2000, at R18. Palmiter further contends that individual investors are not as unsophisticated or in need of protection as proponents of regulation make out, and that they are not systematically less capable of prudential investments than intermediaries. Palmiter, supra note 22, at 18-20. 
Second, successful crafting of adequate investment prohibitions would be problematic. The regulator must determine what foreign investments to prohibit and to whom the restrictions apply, classification choices that will inevitably generate definitional problems of over- and under-inclusion. In addition, because financial markets are dynamic, investment restrictions will need frequent updating or investment flexibility will be lost and investors' returns will suffer. Experience confirms this concern, as the use of investment prohibitions has not been a successful regulatory strategy. For instance, U.S. states have abandoned restrictions on private trust and public sector investments, 41 and the performance of public funds operating under investment restrictions that were difficult to amend has suffered.42 Moreover, restricting investments to locally-regulated issues could create additional problems as legal lists can be employed for political purposes that can have unintended adverse financial consequences: in the United States, for example, some public pension funds that were directed to engage in socially responsible investments favoring local investments experienced sizeable losses on those investments.43 Undoubtedly, there is a cost to implementing a regime disclosure requirement over regulators' use of investment prohibitions as the mechanism of investor protection under regulatory competition: both the gains and losses on investment strategies could be higher for unsophisticated investors when their investment choices are not restricted by the government and they can end up purchasing a security registered under a regime that facilitated fraud. But even when investors are limited to issues regulated by the SEC, which is considered the most stringent securities regime in the world today, they have not been immune to fraud. In truth, the SEC has not eliminated, and it is questionable whether it, or any government regulator, ever could eliminate, all investment fraud. In fact, in one of the most spectacular contemporary fraud cases, the insurance Ponzi scheme undertaken by Equitable Funding Corporation of America, the SEC ironically "repeatedly missed opportunities to investigate Equity Funding" and instead sued the investment analyst who uncovered the fraud for insider trading. ${ }^{44}$

${ }^{41}$ See John H. Langbein, The Uniform Prudent Investor Act and the Future of Trust Investing, 81 Iowa L. Rev. 641 (1996) (detailing change in state law regulating private trusts from restricting specific investments to following general fiduciary standards, as modern portfolio theory changed the concept of a suitable investment by altering the conventional understanding of investment risk); Roberta Romano, Public Pension Fund Activism in Corporate Governance Reconsidered, 93 Colum. L. Rev. 795, 800 (1993) (noting state approaches to public pension fund investments).

${ }^{42}$ South Carolina prohibited public funds from investing in equity, and it was estimated that its pension fund would have earned an additional \$5 million per day between 1994 and 1997 if it had been permitted to invest $40 \%$ of its assets in stocks, or $\$ 1$ million per day if the equity allocation had been $10 \%$. See Susan Barreto, Lost

Opportunities: South Carolina Ends Long Day's Journey into Equity, Pensions \& Investments, May 3, 1999 , at 35. The South Carolina restriction was in the state constitution; similar restrictions in other states were repealed prior to 1997 because, located in statutes, they were undoubtedly easier to change.

${ }^{43}$ Romano, supra note 41, at 803-808.

${ }^{44}$ Dirks v. SEC, 463 U.S. 646, 652 n.8 (1983). In particular, the analyst began investigating Equity Funding in March 1973 on a tip from an insider and within weeks verified and disclosed the fraud, leading to regulatory action against Equity Funding and its bankruptcy filing. Yet "as early as 1971, the SEC had received allegations of 
A better solution to the problem of unsophisticated individuals' investing in inappropriate financial instruments under regulatory competition than enacting investment prohibitions is, in conjunction with the regime disclosure approach, for national regulators to encourage those individuals, through educational programs and information campaigns, to use the expertise of financial intermediaries, such as by investing through mutual funds, rather than to engage in their own stock-picking. Encouraging individuals to use intermediaries not only will provide them with greater investment opportunities than restricting their securities purchases to firms registered under specific regimes, but also will place less of a burden on a national regulator to monitor continuously and minutely the status of other regimes to determine whether they are acceptable domiciles for citizens' investments. It also will reduce the burden of domestic broker regulation, which is an important component for enforcing the regime disclosure requirements, as well as reduce the benefits to issuers of locating in deviant regimes; for as individuals shift to institutional funds for their investment vehicles, informed investors-intermediaries such as mutual funds - will be the ones examining securities' regimes before their purchase. At the same time, by not impeding the flow of firms under regulatory competition, it will maximize the probability that those informed investors obtain the securities regime that they prefer.

\section{Litigation Rights}

Another difficulty for investors under a competitive international regime is the enforcement of individual legal rights against a firm whose securities' domicile is not the state in which they are traded (that is, where the investor resides). ${ }^{45}$ The question is where would the investor be able to sue, for a lawsuit prosecuted abroad is obviously more costly than a domestic one. U.S. investors could, for instance, bring actions in U.S. courts, which would apply the foreign domicile's law rather than the law of the forum. This is a disadvantage in that U.S. judges will not be well-versed in another nation's law and the investors will need legal counsel with foreign law expertise, which may be expensive if there are not sufficient profits from bringing such suits domestically to induce the creation of a specialized local bar. Of course, few federal judges are well versed in domestic securities regulation, so this disadvantage can easily be exaggerated. U.S. judges will, nonetheless, be better able to obtain and master the relevant U.S. legal sources as opposed to foreign law. ${ }^{46}$

fraudulent accounting practices at Equity Funding," but failed to take action or otherwise uncover the fraud. $I d$. at 650 n.3.

${ }^{45}$ Government enforcement is less of a problem: existing agreements between regulatory agencies, see, e.g., supra note 29, call for information sharing and cooperation across agencies in enforcement actions, and there is no reason to expect the abandonment of such arrangements in a competitive international regime.

${ }^{46}$ There is a further disadvantage with local enforcement: it splits the legislative and judicial authority of the securities domicile, and this could limit the efficacy of competition. Regulatory competition is most effective when these two functions are under the same sovereign. Canada, for instance, has not developed vigorous charter 
In addition, if a firm has no other contacts in the United States besides its listing, for such a lawsuit to proceed, the firm might have had to agree to be sued in the United States. ${ }^{47}$ This is not a worrisome problem, however, for it can be expected that foreign-domiciled firms selling shares in the United States will contractually agree to such a requirement in their offering and listing documents in order to induce U.S. investment. If there is sufficient cause for concern that firms will not voluntarily contract to permit local litigation, consent to service of process and personal jurisdiction, analogous to the requirements in U.S. corporation codes that foreign firms wishing to do business in a state must designate a local agent for service of process, ${ }^{48}$ could similarly be mandated by the treaties and conforming legislation establishing mutual recognition of securities domicile.

Issues regarding litigation rights against foreign-domiciled firms should be similarly resolvable in other countries. If they are not, it could limit the effectiveness of international competition, as firms might have to select the listing site as their domicile to satisfy the concerns of such nations' investors over litigation rights. But because securities litigation is far less pervasive and recoveries are smaller outside of the United States, litigation rights are less likely to be a significant issue for investors elsewhere.

Given the difficulties of enforcing litigation rights cross-border, a superior approach to liability issues, were regulatory competition to become firmly established internationally, would be the development of a specialized system of international securities arbitration substituting for securities lawsuits. This is not a novel

competition across its provinces in large part because the provincial governments do not control the adjudication of corporate law disputes: securities administrators of any province and the national Supreme Court share that authority with the incorporation province. See Ronald J. Daniels, Should Provinces Compete? The Case for a Competitive Corporate Law Market, 36 McGill L.J. 130, 182-84 (1991). This renders it impossible for a province to guarantee a responsive legal regime to prospective incorporators, a key factor in U.S. charter competition, see Romano, supra note 22, because other authorities can impose obligations on firms countermanding provincial laws. Although under securities competition, the U.S. courts would be applying foreign law and thus not directly in a position to impose their own law, with less expertise than the relevant foreign court, they might issue disparate rulings from those of the foreign adjudicator. This would have an adverse affect not only on the litigants but also on other parties until the foreign sovereign could act to reverse the U.S. court's action by legislation or by the fortuity of its own court hearing a case posing the same issue. This potential difficulty would be mitigated if U.S. courts were to certify the issue to the foreign court and the latter were willing to accept the certification and promptly decide the legal issue. In addition, in the international securities regulation setting, the cost advantage to investors of litigating locally may well offset the potential cost to them of less perfect competition from this action. But if this were not the cost-benefit calculation made by the majority of investors, issuers could prevent a minority from bringing a securities claim in a court located outside of the securities domicile by inclusion of a forum selection clause in the corporate charter and securities purchasing agreements. To the extent that the validity of such clauses is an issue in some legal systems, the multilateral accord on regulatory competition should include a requirement that national laws implementing the agreement instruct local courts to respect forum selection clauses.

${ }^{47}$ It is, however, quite plausible that the sale of a security would be sufficient under the Supreme Court's "minimum contacts" doctrine to justify in personam jurisdiction over a firm. For a general discussion of the jurisdictional question in corporate law, see, e.g., Harry G. Henn \& John R. Alexander, Laws of Corporations 209-14 (3d ed. 1983).

${ }^{48}$ See, e.g., Del. Code Ann. tit. $8, \S 371$ (2001) (in order to qualify to do business in the state, a foreign 
idea. In international business transactions, arbitration is already the dominant mechanism of dispute-resolution. Arbitration eliminates problems surrounding litigation rights, and it comes with a further important advantage: arbitration judgments are more readily enforceable internationally than those of courts, because virtually all nations have signed the international convention recognizing arbitration awards, while there is no such global treaty on the enforcement of judgments. ${ }^{49}$ For arbitration to replace securities litigation on a global level, however, other nations would have to follow a policy similar to that enacted by Congress and endorsed by the U.S. Supreme Court that explicitly permits the use of arbitration to resolve securities disputes. ${ }^{50}$ In addition, some features of U.S. securities litigation practices might need to be adapted to the arbitration process for it to be an adequate substitute for litigation, such as the use of representative actions, because despite the lower cost of arbitration compared to litigation, the profitability in most securities lawsuits comes from the ability of an attorney to aggregate claims. But since it is not clear-cut whether under present rules, arbitration or litigation would be preferred by most investors, the most appropriate mechanism for ensuring the availability of litigation rights under regulatory competition is to require instead, in the international accords adopting the competitive regime, all states to recognize forum selection clauses, including those selecting arbitration over litigation, for the resolution of private securities disputes.

\section{Investor Approval of Midstream Regime Changes}

A final potential concern for investors under competition might be that after they acquire their securities, the firm changes its securities domicile, to their disadvantage, such as by moving to a regime with a lower level of required disclosure. The concern is that if the change was not anticipated at the time of the stock purchase, the price the investor will have paid for the shares will not reflect the firm's lower value under the new regime, and opportunistic insiders can thereby change domicile and transfer wealth from investors to themselves. This is not, however, a severe problem. Because investors will be aware that a domicile change can be effected midstream, they will discount the shares for the potential opportunism, and hence management will bear the cost. ${ }^{51}$ Indeed, management will have an interest in guaranteeing that they do not engage in subsequent opportunistic behavior regarding domicile, in order to lower the cost of capital when they issue shares. Moreover, appropriately structured incentive compensation aligns managers' and shareholders' interests, reducing further the benefit from

corporation must designate a registered agent in the state to accept service of process).

${ }^{49}$ See Andreas F. Lowenfeld, International Litigation and Arbitration 332 (1993).

${ }^{50}$ For the change in U.S. doctrine resulting in validation of arbitration clauses to resolve securities law disputes, see Rodriguez v. Shearson/Am. Express, Inc., 490 U.S. 477 (1989); Shearson/Am. Express, Inc. v. McMahon, 482 U.S. 220 (1987); Scherk v. Alberto-Culver Co., 417 U.S. 506 (1974), overruling Wilko v. Swan, 346 U.S. 427 (1953).

${ }^{51}$ For evidence that shares subject to opportunism have lower values, see infra note 65 and accompanying 
such opportunistic behavior. In this regard, one study found that the extent of firms' discretionary disclosure policies is positively related to the proportion of salary received in stock by the chief executive officer. ${ }^{52}$

Besides relying on management's self-interest to draft securities contracts that restrict any subsequent domicile change or on stock-based incentive compensation to align management's and shareholders' regime choices, the potential for midstream opportunism can be mitigated by requiring shareholder voting approval before a domicile change is effected as a condition of mutual recognition under the treaties establishing the competitive international regime. ${ }^{53}$ Managers would therefore not be able to switch to a regime with a lower level of disclosure unless their investors prefer such a regime and vote for the move, which would be compelling evidence that the regime shift did not adversely affect them. Although such a voting requirement may not be necessary to protect investors from midstream regime changes adverse to their interest—competing regulators would include such a voting requirement in their regimes if it were desired by issuers and investors, or individual issuers' corporate documents would contain such a requirement—its inclusion in treaties establishing securities regulation competition could make policymakers who are unfamiliar with regulatory competition because they do not operate in a federal system more comfortable with the proposed regime change.

Some commentators contend that shareholder voting is not an effective safeguard against insider opportunism because an individual shareholder's cost of becoming informed in order to vote his or her interest outweighs the pro rata benefit he or she will receive from a correct outcome. ${ }^{54}$ As I discussed in my prior article, with respect to the United States, this contention is erroneous. ${ }^{55}$ In a capital market dominated by institutional investors holding portfolios of stock, issues are repeatedly raised across the investors' portfolio firms, reducing the information cost significantly for any one vote. Moreover, organizations have developed in the United States that provide institutional investors with considerable information regarding how to vote on proxy issues, such as Institutional Shareholder Services and the Investor Responsibility Research Center, further reducing the cost of becoming an informed voter. In addition, many institutions have websites publicizing how they vote their shares,

text.

${ }^{52}$ See Venky Nagar et al., Compensation Policy and Discretionary Disclosure 20-21, $23-24$ (2000) (frequency of voluntary earnings forecasts and analyst ratings of disclosure quality, controlling for other determinants of disclosure, are significantly positively correlated with proportion of CEO compensation dependent upon stock prices, and concluding this evidences optimal contracting between shareholders and managers), at SSRN Electronic Paper Collection, http://papers.ssrn.com/sol3/papers.cfm?abstract_id=224143.

${ }^{53}$ My proposal for regulatory competition in the United States includes such a requirement. See Romano, supra note 2, at 2415-16.

${ }^{54}$ See, e.g., Jeffrey N. Gordon, The Mandatory Structure of Corporate Law, 89 Colum. L. Rev. 1549, 1575 (1989).

${ }^{55}$ Romano, supra note 2, at 2416, 2416 n.181. 
and some even encourage use of their sites to facilitate individual shareholder participation in an activist agenda. ${ }^{56}$ Hence, as with the initial domicile choice, in the absence of bifurcated investor markets, less-informed individual shareholders will be protected by informed voters.

Shareholder activism surrounding the voting process is more developed in the United States than in other countries where there are fewer institutional investors, particularly pension funds, which are the most activist institutions in the United States. This suggests that voting rights may be a weaker protection for non-U.S. investors against opportunism. But there are trends indicating that shareholder voting is developing in other countries, approaching that of the United States. ${ }^{57}$ In particular, U.S. institutions are investors in many non-U.S. firms, and the leading activist investors among U.S. institutions have adopted global corporate governance guidelines, mirroring for foreign firms their policies toward U.S. firms ${ }^{58}$ Indeed, shareholder activism in the EU has increased in direct conjunction with U.S. institutions' greater equity investments. ${ }^{59}$ But U.S. institutions are not the only active investors. The major pension funds from around the world created the International Corporate Governance Network, which has met annually for several years to devise global governance standards and develop governance strategies of concern to institutional investors. ${ }^{60}$ These activities are beginning to have an impact: shareholder proposals at non-U.S. firms have increased in recent years. ${ }^{61}$ Moreover, non-U.S. firms have started to respond to these developments: some Japanese firms, for instance, have scheduled their annual meetings on a date different from all other firms and have moved toward better disclosure of executive compensation, in

${ }^{56}$ See New Websites Post Proxy Voting Activity, 10 IRRC Corp. Governance Highlights 65 (Apr. 16, 1999) (Domini Social Investments, a socially responsible investment fund, is posting how its Equity Fund has voted shares in its 400 firms, as well as adding an investor activism center with information on social issue proxy proposals and permitting e-mail to CEOs of targeted firms); Steve Hemmerick, Internet Helps Link Shareholders, Pensions \& Investments, July 27, 1998, at 3 (discussing how networking on the Internet has linked individual and institutional shareholders on corporate governance issues). Large organizations with websites detailing their corporate governance activities include the California Public Employees Retirement System (CalPERS), the AFL-CIO, and the Council of Institutional Investors, an organization of public and private pension funds that serves as a clearinghouse for the funds' corporate governance activities.

${ }^{57}$ For a view that the German system will evolve toward a proxy -voting system similar to that in the United States with the adoption of registered shares by major companies, see Gregor Bachmann, Registered Shares, Proxy Voting, and German Corporate Governance, 53 Wertpapiermitteilungen 2100 (Oct. 1999), abstracted on Legal Scholarship Network, Corporate Law Abstracts, 2(8) Fin. \& Corp. Gov. L. Accepted Paper Series (June 16, 2000).

${ }^{58}$ See TIAA-CREF Follows Calpers Lead to Adopt Global Guidelines, XVIII IRRC Corp. Governance Bull. Feb.-Apr. 2000, at 23.

${ }^{59}$ See, e.g., Steve Hemmerick, CalPERS Takes New Active Role in U.K., Pensions \& Investments, Jan. 12, 1998, at 2.

${ }^{60}$ Carolyn Brancato \& Michael Price, The Institutional Investor's Goals for Corporate Law in the TwentyFirst Century, 25 Del. J. Corp. L. 35, 68-69 (2000) (comment of Dr. Carolyn Brancato of the Conference Board).

${ }^{61}$ Decline in Capital Proposals, Continued Increase in Other Proposals Mark Global Proxy Season 2000, XVIII IRRC Corp. Governance Bull., May-July 2000, at 13. 
order to stem institutional investors' voting protests over those issues. ${ }^{62}$

It is altogether possible, if not probable, that shareholder activism and the exercise of voting rights are less developed outside of the United States because in other countries, the level of shareholder rights is lower than in the United States. In such circumstances, while voting may not provide significant protection against midstream opportunism, the shares will already be steeply discounted and opportunism over the choice of securities domicile would be a far less important concern than more direct forms of expropriation under corporate law, illustrated by some nations' courts' apparent lack of scrutiny of controlling shareholders' self-dealing transactions in corporate assets. ${ }^{63}$ Indeed, in addition to the lower level of shareholder rights in many countries other than the United States and United Kingdom, in those nations a substantial number of publicly traded firms have controlling shareholders unlike their U.S. and U.K. counterparts. ${ }^{64}$

To the extent that the presence of controlling shareholders makes opportunism regarding a change in securities domicile to the minority's detriment more probable, this is no different from the higher probability of expropriation of a minority by such shareholders under existing domestic corporate and securities law. Similarly, the potential for such opportunistic behavior will be impounded in the stock price. There is, in fact, suggestive evidence that shares trade at a substantial discount in the presence of controlling shareholders and the absence of legal protections for the minority, with significant variations in the discount across countries depending upon the legal opportunities for self-dealing. For instance, the difference in price of the low- or non-voting shares in dual class stock firms compared to the voting shares is substantially larger in countries that provide less legal protection for the minority shareholders (countries where the private benefits of control are large) ${ }^{65}$ In addition, firms in countries with greater shareholder protection trade in deeper capital markets and therefore have better

${ }^{62}$ Japan's Proxy Marathon 2000 Shows Hints of a Sea Change, XVIII IRRC Corp. Governance Bull., MayJuly 2000, at 17 .

${ }^{63}$ See, e.g., Simon Johnson et al., Tunnelling, 90 Am. Econ. Rev. 22 (2000) (describing various forms of permissible expropriation by controlling shareholders in the EU).

${ }^{64}$ See Rafael La Porta et al., Corporate Ownership Around the World, 54 J. Fin. 471, 491-95 (1999).

${ }^{65}$ See Luigi Zingales, The Value of the Voting Right: A Study of the Milan Stock Exchange Experiences, 7 Rev. Fin. Stud. 125, 125-26 (1994) (the premium on voting shares of dual-class firms in Italy is over 80\%, compared to premia of 5\%-20\% in the U.S., England, Canada, Sweden, and Switzerland, and the difference is due to higher benefit of private control in Italy, that is, to greater ability of controlling shareholders to dilute minority property rights); Tatiana Nenova, The Value of Corporate Votes and Control Benefits: A Cross-country Analysis (Harvard Univ. Mimeo, Sept. 2000), available at SSRN Electronic Paper Collection, http://papers.ssrn.com/sol3/papers.cfm?abstract_id=237809 (estimated value of control for 661 dual-class stock firms in eighteen countries, based on model of predicted takeover premia, ranges from $0 \%$ to $50 \%$, and $75 \%$ of crosscountry difference is explained by quality of minority investor protection). See also Andrei Shleifer \& Robert W. Vishny, A Survey of Corporate Governance, 52 J. Fin. 737, 748 (1997) (collecting studies indicating dramatic differences in average voting premia across countries). 
access to external finance. ${ }^{66}$

The possibility of benefiting from minority expropriation (by, for instance, receipt of non pro-rata distributions) distinguishes controlling shareholders from institutional investors, whose presence protects individual investors regarding regime choice because institutional and individual investors share cash flows equally. Controlling shareholders' initial and midstream regime choices may therefore not be the same as those of institutions: they may prefer to trade-off greater secrecy against the price received for shares sold to the public since they obtain benefits from the firm independent of cash dividends. This difference would be eliminated if controlling shares were excluded from the domicile vote, as the securities domicile would then be selected according to the preferences of outside shareholders. But there are two reasons for not mandating such an approach. First, a domicile voting rule excluding controlling shares would, in all likelihood, not be a feasible requirement for an international accord on securities competition, given the political influence controlling shareholders are likely to wield in the many countries in which group control is the predominant corporate ownership structure. Second, individual investors are not likely to be harmed by the difference in securities regime choice made between controlling shareholders and institutions, because stock prices will be discounted for the in siders' choices, just as prices are presently discounted according to the opportunity for insiders to obtain private benefits under existing corporate and securities laws. Since the controlling shareholders bear the cost of potential opportunism, they could, if they wish to increase the price paid for public shares, seek to commit to not changing domicile opportunistically, by placing in their charter a supermajority domicile voting rule, locked-inbya supermajority vote for repeal, or by otherwise contracting to vote their shares in proportion with the votes of outside shareholders.

To the extent that either supermajority charter provisions are not permissible or voting agreements are not enforceable in particular countries, controlling shareholders would not be able to commit to only value-enhancing domicile shifts. Although the public would not bear the cost of opportunism over domicile changes in this situation, there would be a welfare loss, as both sets of shareholders would be better off if commitment were possible and share prices were higher. However, if the politically influential controlling shareholders have a preference for commitment devices that are not achievable under domestic corporate law, they could lobby their governments either to sign treaties with provisions that facilitate pre-commitment strategies, such as excluding controlling shares from voting on domicile changes, or to revise domestic law to enable the use of effective commitment devices.

\footnotetext{
${ }^{66}$ Rafael La Porta et al., Legal Determinants of External Finance, 52 J. Fin. 1131 (1997) (across forty-nine countries, firms in nations with greater shareholder protections have better access to external finance, i.e., capital markets are larger and deeper).
} 
Voting is not a foolproof protective mechanism against a midstream domicile change, whether or not there are controlling shareholders. But voting approval of domicile changes is undoubtedly preferable to the alternative of prohibiting midstream changes in a firm's securities domicile. Prohibition has obvious disadvantages, for as business conditions change, so do firms' needs, and an initial domicile choice may no longer be the optimal regime. Moreover, unless firms can choose a different regime for each security issue to circumvent the prohibition of a domicile change, an option that could unduly complicate the regulatory regime, such a prohibition will seriously undermine the efficacy of regulatory competition. This is because such a restriction reduces the type of firms available to influence transaction flows across regimes to only newly-traded firms and thereby greatly attenuates regulators' incentives to adapt their regimes in response to investor preferences (the number of firms they could attract by being responsive would be small).

\section{Criticisms of Regulatory Competition}

Critics of competition in securities regulation often blur the true issue by referring to their position not as a defense of a single regulator but as a defense of mandatory disclosure, on what is, in my judgment, a fantastic premise, that there would be no significant disclosure component in a competitive international regime. Objections to competition have, accordingly, often been inseparably intertwined with a defense of the SEC's mandatory disclosure regime. In order to promote the goal of achieving regulatory competition, this Part therefore addresses the efficacy of the SEC's regime.

The two principal rationales that have been offered against regulatory competition and in defense of the SEC's monopoly over U.S. issuers (as well as over foreign firms selling shares in the United States) are that there are significant interfirm externalities regarding information, such that investors will not want their firms to disclose the socially optimal amount, and that choice of regime will result in a "race to the bottom" with minimal or no disclosure. At the time of the enactment of the federal securities laws in the 1930s, there was a further argument for regulation at the national level: concern that fraud could not be prosecuted across state lines. ${ }^{67}$ This concern is not relevant under modern long-arm jurisdictional doctrines, and there is a pattern of well-established cooperation in enforcement actions by state authorities; correspondingly, it has not been the focus of critiques of regulatory competition and is not discussed in this paper. ${ }^{68}$

Among critics of regulatory competition, Merritt Fox has most strenuously questioned the proposal I

${ }^{67}$ See Joel Seligman, The Historical Need for a Mandatory Corporate Disclosure System, 9 J. Corp. L. 1, 21 (1983).

${ }^{68}$ For a discussion of the antifraud rationale for the SEC and the data regarding the SEC and investor protection against securities fraud, in relation to the need for retention of a single regulator in the United States, see Romano, supra note 2, at 2368-69, 2381-83. 
advanced to open up U.S. securities regulation to competition. ${ }^{69}$ Fox emphasizes the interfirm externalities rationale for a single regulator. The race-to-the-bottom rationale endorsed by advocates of the $\mathrm{SEC}$ regime ${ }^{70}$ is in essence a restatement of the view of competition, advanced most prominently by William Cary, to describe Delaware's dominance in U.S. corporate law, as a "race to the bottom" in which managers select regimes that facilitate their exploitation of shareholders. ${ }^{71}$ Both of these objections to regulatory competition-the importance of interfirm externalities and a race to the bottom over disclosure policy—were addressed briefly in my prior article. ${ }^{72}$ Fox thereafter published a lengthy article in criticism of the arguments in my article that questioned the information disclosure rationale for a single regulator. This Part responds in detail to Fox's critique, as well as to critics espousing the race-to-the-bottom characterization of competition, demonstrating that the case for a single regulator is deeply problematic.

\section{A. The Information Failure Rationale for a Single Regulator}

The conventional economic explanation for governmental intervention in the allocation by markets of goods and services concerns conditions under which market pricing will not produce the optimal output because the product's marginal cost and benefit cannot be properly equated by private parties. These cases include the presence of externalities, where costs and benefits accrue to parties other than the contracting parties and thus are not internalized or priced in a market transaction, and public goods, whose marginal cost of production is zero and hence the value to additional users is not captured by the producer under the pricing mechanism of a market.

Firm information used in investment decisions has often been characterized as a public good, although

${ }^{69}$ See Fox, supra note 3; Fox, supra note 13.

${ }^{70}$ See, e.g., Cox, supra note 3, at 1233-36; Fox, supra note 13, at 2626-27 (contending that nations competing for securities transactions will engage in a race-to-the-bottom due to political pressures to reduce disclosure); Fox, supra note 3, at 1410 (contending that under competition managers will choose "as low a level of periodic disclosure as possible"); Joel P. Trachtman, Regulatory Competition and Regulatory Jurisdiction in International Securities Regulation, in Regulatory Competition and Economic Integration 289 (Daniel C. Esty ed., 2001) ("under [competition] some state, such as the Cayman Islands or Mongolia, would move to the reductio ad minimum: imposing no substantive obligations"), available at SSRN Electronic Paper Collection, http://papers2.ssrn.com/paper.taf?ABSTRACT_ID=193688. In addition to his express "race to the bottom" criticism of regulatory competition regarding managers' "self-interested" behavior quoted above, which he maintains will not be checked by investors, Fox, supra note 3, at 1411, Fox's externalities argument entails a "race-to-the-bottom" form of objection to competition because his rationale for regulation is that issuers disclose less than the optimal level and therefore competing regulators who are responsive to issuers will necessarily reduce the level of mandated disclosure, beyond what they would otherwise require. Merritt Fox, The Political Economy of Statutory Reach: U.S. Disclosure Rules in a Globalizing Market for Securities, 97 Mich. L. Rev. 696, 796 (1997) ("given the preferences of the persons making these choices [choices of securities regime under regulatory competition] issuers will generally choose regimes requiring a lower than socially optimal level of disclosure.”).

${ }^{71}$ See William Cary, Federalism and Corporate Law: Reflections upon Delaware, 83 Yale L.J. 663 (1974).

${ }^{72}$ Romano, supra note 2, at 2368, 2374-75, 2380-81, 2420-21. 
whether it is under- or overproduced is subject to debate. The conventional public goods analysis suggests that information about a security will be under-produced by the issuer, ${ }^{73}$ but because sizeable trading gains can be captured by the first person to discover private information about a firm, such information may instead be overproduced. ${ }^{74}$ Both explanations can be used to advocate government intervention to mandate disclosure at the optimal level, but supporters of securities regulation typically rely on the underproduction rationale. ${ }^{75}$

It is, in fact, implausible that there would be a significant underproduction of firm information in the absence of a single securities regulator, that is, under a competitive regime in which firms have a choice among disclosure regimes. Firms have a strong incentive to distinguish themselves by providing information about their projects to obtain capital. Firms with unfavorable information also are forced to disclose information about their projects, because an adverse signal will be drawn by investors concerning firms that do not disclose information (no news is bad news). ${ }^{76}$ Fostering this phenomenon is the principle of conservatism in accounting: the preference of accountants to "require a higher degree of verification to recognize good news as gains than to recognize bad news as losses. ${ }^{\prime 77}$ This preference is not simply one held by regulators but also a preference of market participants: a study of departures from U.S. accounting standards in private debt covenants, for instance, reports that all such departures were conservative. ${ }^{78}$

The signaling hypothesis regarding information disclosure is a plausible scenario in today's capital markets in which the majority of investors are sophisticated institutional investors. Despite varying assumptions, the formal models of the disclosure that is made in signaling equilibria conclude that information will not be underproduced if a sufficient number of investors understand the significance of nondisclosure. ${ }^{79}$ It is therefore theoretically difficult for advocates of mandated disclosure to maintain their normative claims, as they cannot

${ }^{73}$ See William H. Beaver, The Nature of Mandated Disclosure, Report of the Advisory Committee on Corporate Disclosure to the SEC, 95th Cong., 1st Sess. (1977).

${ }^{74}$ See Jack Hirshleifer, The Private and Social Value of Information and the Reward to Inventive Activity, 61 Am. Econ. Rev. 561, 565-66 (1971).

${ }^{75}$ E.g., John C. Coffee, Jr., Market Failure and the Economic Case for a Mandatory Disclosure System, 70 Va. L. Rev. 717 (1984).

${ }^{76}$ The classic signaling model of securities disclosure is Stephen A. Ross, Disclosure Regulation in Financial Markets: Implications of Modern Finance Theory and Signaling Theory, in Key Issues in Financial Regulation 177, 185-89, 213 (Franklin Edwards ed., 1979).

${ }^{77}$ Sudipta Basu, The Conservatism Principle and the Asymmetric Timeliness of Earnings, 24 J. Acct. \& Econ. 3, 7 (1997). Basu provides empirical support for this view of the effect of conservatism in tests of the relation between stock returns and earnings, which indicate that firms' earnings reflect bad news more quickly than good news.

${ }^{78}$ Richard Leftwich, Accounting Information in Private Markets: Evidence from Private Lending Agreements, 58 Acct. Rev. 23 (1983).

${ }^{79}$ See, e.g., Ronald A. Dye, Investor Sophistication and Voluntary Disclosures, 3 Rev. Acct. Stud. 261 (1998); Michael J. Fishman \& Kathleen M. Hagerty, Mandatory vs. Voluntary Disclosure in Markets with Informed and Uninformed Customers (Kellog Graduate Sch. of Mgmt. Working Paper No. 233, Aug. 1999). 
advance a supportive formal model. They can, however, seek to revive their position empirically, by disputing whether there will be a sufficient number of investors who will interpret silence as indicative of adverse information for a signaling equilibrium to emerge. But this line of analysis is not terribly promising either, because it is not a credible contention in today's institutional marketplace. Hence, the underproduction of information rationale for securities regulation does not provide a reason for opposing the introduction of regulatory competition.

In contrast to other defenders of the status quo in securities regulation, Fox, in his critique of my position, does not rely on the conventional public goods rationale to advocate the need for a single regulator. Rather, he adopts the position suggested by Frank Easterbrook and Daniel Fischel, which is an information failure with a twist. If there is a problem regarding the voluntary production of information about securities, in this perspective it does not concern information of interest to the firm's investors - that information will be optimally produced by the firm voluntarily — but, rather, concerns information that is of value to third parties not investing in the firm: the firms' competitors. ${ }^{80}$ Fox maintains that social welfare requires the disclosure of such information; his premise is that the lower welfare of the disclosing firms and their investors is offset by the increased welfare of the disclosing firms' competitors. Because disclosure is unambiguously bad for the disclosing entity in this scenario, firms will not voluntarily disclose such information and there is a market failure calling for government intervention.

Although Easterbrook and Fischel were the first to offer the third-party externality rationale for federal securities regulation, in contrast to Fox, they are, in fact, agnostic concerning the efficacy of the SEC's mandatory disclosure regime. In particular, they, as do I, find the empirical data more damaging to the $\mathrm{SEC}^{81}$ than Fox does. In addition, they put forth the third-party externalities argument more as an aside and a possible explanation for the U.S. status quo, among other explanations, ${ }^{82}$ whereas Fox rejects other explanations and uses

${ }^{80}$ See Frank H. Easterbrook \& Daniel R. Fischel, The Economic Structure of Corporate Law 290-91 (1991).

${ }^{81} I d$. at 314 .

${ }^{82}$ It should also be noted that a key factor underlying Easterbrook and Fischel's thesis was the belief that a competitive regime could not resolve jurisdictional problems such that only one state's rules would govern a firm's disclosures, as is true of a firm's "internal affairs" (the statutory domicile approach of corporate law). Their concern here appears, however, to be different from Fox's regarding the disclosure of information to rivals: they fear interstate exploitation without a national regime. Namely, in their example, an investor in a firm incorporated under an efficient disclosure regime of state $\mathrm{D}$ sues in her home state $\mathrm{N}$ for the firm's noncompliance with $\mathrm{N}$ 's inefficient disclosure rules, and state $\mathrm{N}$ can thus extract a wealth transfer for its citizens from the firm's investors in the other forty-nine states. Id. at 301-02. If, as an effective competitive securities regime requires, a sole securities statutory domicile is recognized, this objection concerning the possibility of interstate exploitation under competition disappears. It is somewhat puzzling but not a complete surprise that Easterbrook and Fischel did not consider this simple solution to their hypothetical problem - the possibility of changing the choice-of-law rule for securities transactions. The overarching concern motivating their book was to rationalize the existing regime where possible, and as I discussed in my earlier article, it would most likely require an act of Congress to implement securities regulation competition and 
interfirm externalities as a centerpiece to develop a proposal regarding the appropriate regime for international securities regulation that would lessen the scope of the SEC's jurisdiction over foreign issuers, by allocating jurisdiction to the regulator of the issuer's physical domicile, rather than the listing site.

\section{B. Why the Information Failure Rationale Does Not Make for a Successful Case against Regulatory Competition}

Fox adopts Easterbrook and Fischel's rationale for the SEC's monopoly over U.S. issuer regulation, but without the caveats they raise concerning its persuasiveness. He maintains that the presence of significant interfirm externalities regarding information about a firm's projects requires the SEC's mandatory disclosure regime and that disclosure of such information cannot be duplicated by a competitive regime. I noted three objections to this contention in my prior article, which Fox found inadequate. ${ }^{83} \mathrm{I}$ therefore elaborate upon them here. First, theoretically, the presence of such externalities does not render a mandatory regime optimal, compared to a voluntary regime. Second, in practice, a majority of investors hold diversified portfolios and will, in contrast to issuers, therefore be able to internalize the externalities with which Fox is concerned, such that a single regulator regime will not clearly dominate multiple regulators. Third, even if there were a theoretical basis for advocating a mandatory disclosure regime due to interfirm externalities, this does not mean that such a regime could be effectively implemented. There is no evidence that the information the SEC requires is of the substantive sort that Fox envisions is significant for rivals' competitive position, and there are highly suggestive data that the SEC, in fact, does not require the disclosure of such information.

\section{Does the Presence of Interfirm Externalities Require Mandatory Disclosure?}

Ronald Dye has modeled the policy choice between voluntary and mandatory disclosure in the presence of interfirm externalities, precisely the context motivating Fox's (and Easterbrook and Fischel's) theory of securities regulation. ${ }^{84}$ The model indicates that mandatory disclosure is not always superior to voluntary disclosure and would, in fact, be difficult for a regulator to implement optimally. It thus is a serious challenge to the persuasiveness of Fox's position. I referred briefly to Dye's model in questioning Fox's position in my prior article, and Fox thereafter spent considerable time and effort critiquing the model. Fox's objections to Dye's model are, however, insubstantial. In addition, a more recent model by Anat Admati and Paul Pfleiderer of

change the jurisdictional rule, see Romano, supra note 2, at 2411, action that would undoubtedly encounter substantial political resistance by state securities regulators and the plaintiff's bar, as well as the SEC.

${ }^{83}$ E.g., Fox, supra note 3, at 23 ("Romano does not explain her assertion").

${ }^{84}$ Ronald A. Dye, Mandatory Versus Voluntary Disclosures: The Cases of Financial and Real Externalities, 65 Acct. Rev. 1 (1990). 
disclosure policy in the presence of interfirm externalities avoids several of Fox's criticisms of the limitations of Dye's model, but has the same key result, namely, that mandatory disclosure regulation does not always improve social welfare. ${ }^{85}$

a. Dye's model of optimal disclosure policy in the presence of interfirm externalities. Dye's model distills the choice of disclosure policy to the following simple timeline: the insider manager or entrepreneur chooses a disclosure regime, which is stylized as a revelation of the entrepreneur's estimate of the precision (which is the reciprocal of the variance) of the firm's expected cash flow; and next the estimate of the firm's expected cash flow is revealed and the firm is sold to investors, who then receive the realized cash flow. Thus, it is a singleperiod model in which investors do not obtain information on their own.

Within this setup, Dye considers two types of externalities: financial externalities, where the disclosing firm's information affects solely investor perceptions of the value of other firms; and real externalities, where the disclosed information affects actual value (that is, the cash flows) of other firms. The latter type of externalities is the sort of information emphasized by Fox as requiring regulatory intervention. The model has the following results. When externalities are financial, voluntary disclosure and optimal mandated disclosures virtually always coincide; when externalities are real, however, there is a divergence in firms' disclosure under a mandatory compared to a voluntary regime. ${ }^{86}$

The nature of the divergence depends upon the relation across firms' returns (that is, upon how the specified disclosure affects the returns of other firms as well as that of the disclosing firm). If the firm's private return from a disclosure is negative and the market-wide return (the return to other firms) is positive, then mandatory rules increase disclosure; if the situation is reversed and the firm's private return is positive while the market-wide return is negative, then there is greater disclosure under a voluntary regime. ${ }^{87}$ For a mandatory disclosure regime to produce the optimal disclosure level, a regulator must possess a priori knowledge of the relation between private and market returns concerning specified disclosures. In fact, this is information a government regulator cannot possibly know at the time its disclosure policy is established. The point of this extensive discussion of Dye's model is that it makes plain a serious analytical flaw in Fox's normative position: it is not theoretically unambiguous, as Fox maintains, that the presence of interfirm externalities requires a mandatory disclosure regime. ${ }^{88}$

\footnotetext{
${ }^{85}$ Anat Admati \& Paul Pfleiderer, Forcing Firms to Talk: Financial Disclosure Regulation and Externalities, 13 Rev. Fin. Stud. 479 (2000).

${ }^{86}$ Dye, supra note 84 , at $15,18-19$.

${ }^{87}$ Id. at $18-19$.

${ }^{88}$ It should be noted that whether a competitive regime would approximate voluntary or mandatory disclosure levels is not patently obvious, despite Fox's clear opinion regarding the former; this depends on investor
} 
Fox does not question the specific results of Dye's model; they follow from the setup of the model. Fox instead criticizes the realism of the model on a number of dimensions and thus its relevance for policy analysis. Of course, all models abstract from reality and are therefore unrealistic on some dimension; that is why they are called models. The relevant question is whether the model has abstracted away crucial institutional elements to render the analysis uninformative or misleading.

b. Is Dye's model's timeline an accurate representation of securities sales and the selection of a disclosure policy? Dye's model adopts the following timeline of events: the entrepreneur selects a disclosure policy before he has complete information about the value of the firm and before he sells shares to investors. Fox objects to this timing of disclosure as unrealistic. ${ }^{89}$ Selecting a disclosure policy prior to the receipt of information about the firm and the sale of securities is, however, quite consistent with the operation of securities markets. As Dye notes, in the real world, firms commit to a disclosure regime, which includes a commitment to making subsequent disclosures, before they have the information that will subsequently be disclosed about them $;^{90}$ this occurs in the decision to list on a particular stock exchange or to go public and be subject to the SEC's continuous disclosure regime (or under the proposed competitive securities regulation approach, in the choice of regulator). This decision is made before specific information about the firm is known; it cannot be otherwise, because the firm is an ongoing entity that continues to operate after the disclosure regime is chosen.

A concrete example of the stickiness of accounting policy choices that indicates the aptness of the model's structure of a disclosure choice as a pre-commitment device involves the selection of the frequency of segment reporting. Over the past decade, once firms decided to disclose segment data on a quarterly basis, which was a voluntary disclosure because such reporting was mandated only on an annual basis, they continued to do so and did not abandon the practice. ${ }^{91}$ In addition, accounting rules typically require consistency over time, whereby once a firm has committed to specified disclosures, it is prevented from changing that disclosure, despite receipt of new information concerning operations that might render it desirable to alter the information being provided to investors. Again, segment accounting provides an illustration: the original segment accounting rule required consistency in segment definition, such that once a firm committed itself to a specific set of segment disclosures, it could not alter its segment reporting based on new information rendering a different definition desirable. ${ }^{92}$

preferences, as discussed in infra Part III.B.2.

${ }^{89}$ Fox, supra note 3, at 1347-49.

${ }^{90}$ See Dye, supra note 84 , at 5.

${ }^{91}$ See Chris tine A. Botosan \& Mary S. Harris, Motivations for Changes in Disclosure Frequency and its Consequences: An Examination of Voluntary Quarterly Segment Disclosures, 38 J. Acct. Res. 329 (2000).

${ }^{92}$ See Financial Accounting Standards Bd., Statement of Financial Accounting Standards No. 14: Financial Reporting for Segments of a Business Enterprise (1975). As discussed at infra note 445, this rule was changed to require segment reporting that was consistent with internal evaluations, which eliminated the need to require time- 
In addition, presale disclosure is, of course, precisely what happens in he real world of equity investments: in an IPO, investors do not buy shares prior to receiving information about the firm (whether there is an SEC mandating such disclosure prior to purchase or not). Indeed, whenever an investor buys a security, the purchase is made, and the price is set, on the basis of existing information about the firm and knowledge of what its future disclosure policy will be, not on the basis of the specific content of future disclosures. It cannot, of course, be otherwise; neither insiders nor investors are clairvoyant or omniscient. Fox cannot truly object to this timeline construction.

However, to demonstrate that Dye's assumption on disclosure occurring before a sale is unrealistic, Fox states that before an issuer goes public, it has no reason to disclose any information. ${ }^{93}$ This claim completely misses the mark. The sale of a security is not simultaneous with information disclosure: investors decide to purchase shares after receiving information about a firm. This is the very timeline of decision-making in the model. The firm makes a decision regarding disclosure in the model because it has decided to sell shares. Thus, Fox's objection to modeling disclosure occurring before sale because a firm would not make disclosures before it sells shares is misplaced. Once the firm is going to sell shares, it will adopt some form of disclosure before the sale is undertaken. If Fox is correct and a firm does not disclose any information at all, including information about future disclosure policies, it could not induce investors to purchase its securities at a price at which the owner would be willing to sell, because such securities would have little value to outside investors. Fox is correct that a firm that has no intention of seeking outside investors will, in all likelihood, not disclose any information; but such a firm is not in the universe of firms of interest to the model or to anyone thinking seriously about securities regulation.

Either recognizing that his objection is a nonstarter or arguing in the alternative, Fox next states that if a firm does disclose information before selling shares, there can be no commitment to a truthful disclosure policy if the manager does not know the content of disclosure to be made under the policy, and hence the model is still unrealistic. ${ }^{94}$ This, of course, is an admission that dispenses with the objection that Fox had previously made regarding the realism of the model's timeline with respect to disclosure and sale. But this new objection is also a groundless objection. The mechanism of commitment is not technically necessary for Dye to analyze further, because in his model, there is no private information-after the entrepreneur's disclosure policy is chosen, he reveals the information and the information is public, commonly known to both the entrepreneur and investors, so there is no truthfulness problem.

consistent definitions.

${ }^{93}$ Fox, supra note 3, at 1348.

${ }^{94}$ Id. 
Dye uses the convention of public information to be able to investigate the disclosure policy choice in the simplest setting, eliminating the need to model a more complicated signaling game. ${ }^{95}$ As Dye notes and as I have already mentioned, the signaling literature shows that firms have an incentive to disclose truthful information to avoid adverse selection problems, so abstracting away the possibility of inside information is not a serious limitation, because retaining it does not raise an interesting modeling issue. Dye's setup is comparable to a disclosure policy choice, which firms make all the time, such as their selection of an accounting rule that will be applied over the years of the firm's financial reporting in the future, without knowing what the actual financial results will be when the rule is applied.

Given that he questions the model's assumption regarding the entrepreneur's ability to commit, rather than its lack of signaling capacity, Fox's objection to Dye's setup implies that in the absence of a mandatory disclosure regime, commitment to truthful subsequent disclosure is impossible and firms will make false statements with impunity. Assuming that a mandatory disclosure regime is equivalent to a rule against fraud is not only incorrect but it begs the entire question of interest in the model: What is the appropriate disclosure regime when interfirm externalities are present? More important, the assumption of the unavailability of commitment and the identification of mandatory disclosure with an antifraud regime does not comport with any world in which we can imagine investors transacting. In all the states of the worlds in which one would model stock purchases, there will be a rule against fraud and hence there will be a mechanism for commitment regarding the accuracy of disclosed information prior to the specific disclosure.

In Fox's setup, firms disclose information and are sued if the information they provide is false; but this is not the only possibility regarding disclosure practices. Firms can also commit to following specific disclosure policies in the future and can be sued if they do not do so, for the failure to disclose the promised items could be considered a fraud on the purchaser (either a material misstatement or omission). Fox's contention that it is impossible to make a commitment to engage in future disclosure without knowing the content of the disclosure is implausible given real-world disclosure practices, and hence his corollary, that Dye's model is irrelevant, is incorrect. To repeat, a pre-commitment to disclosure without knowing the content is typically the form that a firm's selection of its accounting disclosure policy takes. Commitment explanations of behavior, in which one party to a transaction commits to following a course of action without advance knowledge of the details and effects the course of action will have except that it will require subsequent disclosure, and in which another party

${ }^{95}$ The Admati-Pfleiderer model of third-party effects, discussed in infra Part III.B.1.e., is closer to a signaling model as the firm has private information, and it does not produce dramatically different results with respect to the determinateness of normative conclusions regarding mandatory disclosure. But this model also assumes that all disclosures are truthful and that the chosen signal does not depend on the realized value of the firm. See infra text accompanying notes 124-125. 
(or parties) reasonably relies on that commitment, are in fact, quite common, the most relevant application being commitment explanations of firms' listing decisions. ${ }^{96}$

Fox also recognizes that accountants can certify financial statements; ${ }^{97}$ this again indicates that the claim that the model has no connection to the real world because there would be no means to commit to information in the absence of a mandatory disclosure regime is incorrect. For such a commitment is exactly what the firm is making when it agrees to provide audited financial statements to investors. Fox then qualifies his objection to the commitment feature of the model by stating that accounting certification violates the assumption in Dye's model that the insider does not have specific information before committing to a disclosure policy. Here too, Fox is wrong. The commitment to use a certified accountant occurs both prior to the knowledge of firm-specific information (such as when a firm lists on an exchange that requires audited financial statements or subjects itself to a disclosure regime that does so or adopts a specific accounting method in the many instances entailing a choice and this method is maintained into future years) as well as at the time of a certified financial statement's release. The use of accountants is thus not an example of a mechanism outside of the model or a "stretch," as Fox claims; ${ }^{98}$ it is a straightforward commitment device within the model's setup.

Finally, Fox objects that the model is unrealistic because the commitment to a disclosure policy regarding the accuracy of the estimate of the firm's expected return will not affect the price investors pay, as it does not provide information about the price. ${ }^{99}$ This objection is mistaken. Fox has simply misunderstood the timeline. In Dye's model, after commitment to a disclosure policy, investors learn the value of the firm as estimated with the precision the manager has chosen in advance, and then they set the price they will pay for the firm, which depends upon the estimate and, hence, the disclosure policy (the precision) chosen. ${ }^{100}$

A more problematic feature of the model's timeline is that it is a one-period model, while firms operate and, hence, engage in disclosures over many periods. This is not, however the concern that Fox has articulated.

${ }^{96}$ See, e.g., Fuerst, supra note 11; Jeffrey N. Gordon, Ties that Bond: Dual Class Common Stock and the Problem of Shareholder Choice, 76 Cal. L. Rev. 2 (1988) (discussing NYSE listing as a commitment device to following a one-share one-vote rule).

${ }^{97}$ Fox, supra note 3, at 1348.

${ }^{98} I d$.

${ }^{99}$ Id. at 1349.

100 Technically, the firm's future cash flows have a normal distribution with an unknown mean $\mu$, the entrepreneur's disclosure is represented by $x$, an unbiased estimate of $\mu$, and his disclosure policy consists of a specification of the precision, $r$, which is the inverse of the variance of the sample estimate, $x$. Because there is no private information in this model, the choice of precision $r$ and the realized sample estimate $\mathrm{x}$ are publicly known; the only information the entrepreneur receives about $\mu$ is the sample estimate $\mathrm{x}$. The two extreme choices of a disclosure policy are $r=0$ (no disclosure) and $r=8$ (full disclosure). If the entrepreneur chooses $r=8$, he must reveal $\mu$, and if he chooses $r=0$, his disclosure reveals nothing and will not affect investors' beliefs about the distribution of cash flows. Dye, supra note 84 , at 4. 
A multi-period model would surely be more realistic than Dye's single-period model, and the results of multiperiod models can differ significantly from those of a single-period model. But the possibility that a multi-period model might produce different results from a single-period one does not mean that no insight can be derived from the latter model. To the contrary, the most famous finance model, the capital asset pricing model ("CAPM"), is a single-period model. Researchers have used the CAPM model for decades for the insights it provides into portfolio selection and stock pricing, despite its theoretical limitation. More important, there is no reason to believe that a multi-period version of the model would further Fox's position, as such models are typically far less tractable than single-period models and hence even less apt to produce determinate results. ${ }^{101}$ In any event, to the extent that we conceptualize the choice of a disclosure regime-such as occurs with the choice of going public or the choice of an accounting method-as a one-time event, which is a plausible interpretation given the stickiness in firms' accounting choices as well as reporting consistency requirements, a single-period model is entirely appropriate.

c. Fox's objections regarding the stylized transaction in Dye's model. Fox raises two objections to the structure of the disclosure choice in Dye's model, unrelated to the model's timeline of events. First, he contends that the model is irrelevant because the entrepreneur, rather than the firm, is selling the shares. ${ }^{102}$ Second, he contends that the model is irrelevant because its disclosure policy concerns information regarding the riskiness of returns and the transfer of risk between entrepreneurs and investors, and in the particular setup, investors are risk-averse. ${ }^{103}$ Both of these objections, on inspection, are insubstantial.

There is, in fact, nothing unrealistic about a model in which an insider sells his ownership of a firm to public investors. Many IPOs are accompanied by insider sales. For example, in a sample of 310 firms that went public over 1994-1997 studied by Robert Daines and Michael Klausner, insiders sold shares in $40 \%$ of the IPOs. ${ }^{104}$ Hence, Dye's model is capturing a large number of transactions. Moreover, Fox does not limit his

${ }^{101}$ One of the better-known examples of the complication resulting from the extension of a single- to a multiple-period model is the prisoner's dilemma in non-cooperative game theory, in which a multi-period structure without a known final period produces numerous equilibria in contrast to the unique equilibrium of the single-period game. See, e.g., Robert J. Aumann, Game Theory, in 2 The New Palgrave: A Dictionary of Economics 460, 469 (John Eatwell et al. eds., 1987). See also infra text accompanying note 131.

${ }^{102}$ Fox, supra note 3, at 1348.

${ }^{103} I d$. at $1348-49$.

${ }^{104}$ The study is Robert Daines \& Michael Klausner, Do IPO Charters Maximize Firm Value? Antitakeover Protection in IPOs, 17 J.L. Econ. \& Org. 83 (2001) (information concerning insider sales provided by Robert Daines to the author). In Daines and Klausner's study, the average percentage of shares sold in the IPO by the firm was $35 \%$, with the average percentage shares sold by insiders $12 \%$, and the CEO's ownership declined on average $7 \%$ after the offering. Id. at 93 (Table 1, Panel B). In another study of 1019 IPOs issued over 1988-1992, the average percentage of shares offered as a fraction of outstanding shares was $32.5 \%$ and the average shares offered by insiders as a fraction of shares offered was 15.5\%. See Laura C. Field \& Jonathan Karpoff, Takeover Defenses at IPO Firms 31 (Aug. 30 , 1999) (Table 1), at SSRN Electronic Paper Collection, http://papers.ssrn.com/sol3/papers.cfm?abstract_id=236043. 
normative argument regarding the need for mandatory disclosure to IPOs that do not include insider sales of securities, nor would it make sense to do so. Accordingly, it is puzzling why Fox would think that a model of such transactions is irrelevant to disclosure regulation. In addition, given the model's other structure regarding the timing of the choice of disclosure, information release and sale of securities, modeling a partial sale would not illuminate anything important beyond that provided for in the model's complete sale setup, with respect to the issue regarding the efficacy of a mandatory disclosure regime. Finally, Fox does not provide any theoretical or empirical basis for expecting the results of the model to change in any significant way if the seller of the shares was denominated the "issuer" rather than an "entrepreneur."

Beyond calling this feature of the model—modeling the transaction as a sale of the insiders' shares unrealistic, Fox suggests that sales of securities that transfer control are not as important to the economy as those that fund new projects. ${ }^{105}$ But there is evidence to the contrary. For instance, a key explanation for the extraordinary success in the most vibrant and innovative sector of the U.S. economy, the high-technology sector, compared to other countries, is the ability of entrepreneurs and their financiers to sell their shares by going public. $^{106}$

The full-ownership sale is a simplification consistent with the model's single-period assumption. A more complex model involving multiple periods would facilitate the modeling of partial control sales and would certainly be of value. But to assume, as does Fox, that a more complex model would demonstrate that interfirm externalities are only positive and optimally resolved by the SEC's regime is farfetched. Fox's attempt at distinguishing issuers and entrepreneurs has no bearing on this issue. To underscore the point made earlier, the more complicated the model, the greater the probability that the results will be ambiguous. ${ }^{107}$ Hence, it is most plausible that a more complex model than Dye's model would not further Fox's position because it would require even more restrictive parameter assumptions for a regulator to get the disclosure regime right in order to increase social welfare.

\footnotetext{
${ }^{105}$ Fox, supra note 3, at 1348 (referring to sales in which the insiders do not sell shares as a "transaction more vital to the economy").

${ }^{106}$ See Bernard S. Black \& Ronald J. Gilson, Venture Capital and the Structure of Capital Markets: Banks Versus Stock Markets, 47 J. Fin. Econ. 243 (1998). Although most venture capital firms do not sell their shares directly in the IPO, undertaking a "lockup" agreement to refrain from selling for several months and then distributing the shares in kind to their investors, who resell the shares in the open market, primarily to avoid SEC restrictions, see Paul Gompers \& Josh Lerner, The Venture Capital Cycle 266 (1999), without the ability to reap the profits from a successful public offering, Black and Gilson suggest that these investments would not be undertaken in the first place. While venture capital sell-outs are not accomplished by means of the simple one-step sale of the Dye model, this does not diminish the analytical point that insider sales are as crucial as firm-level sales for capital formation and economic growth.

${ }^{107}$ See supra note 101 and accompanying text.
} 
Fox also objects to Dye's modeling investors as risk-averse. ${ }^{108}$ However, because Dye indicates that the results regarding the relation between real externalities and mandatory disclosure are unchanged if investors are risk-neutral, ${ }^{109}$ this is a mistaken objection. The assumption of investor risk aversion does not affect the model's results.

Finally, Fox objects to the stylistic choice to model disclosure policy as a choice regarding the precision of the information to be disclosed that affects the distribution of risk across firms and investors. Fox elaborates on this objection by characterizing it as an assertion that disclosure only concerns risk reduction and risk shifting, and he thus dismisses the model as irrelevant. ${ }^{110}$ The objection, however, is false. First, there is absolutely nothing unusual about modeling insiders selling shares in their firms to public investors in order to reduce their risk. The foundational article on the theory of the firm by Michael Jensen and William Meckling, for example, advances this as the explanation for the separation of ownership and control in the modern U.S. corporation, ${ }^{111}$ and their theory of agency costs is one on which Fox relies in building up his argument regarding the optimal regulatory regime, as well as in questioning Dye's article. ${ }^{112}$ Diversification is the essence of modern capital markets, and that is what the entrepreneur uses the capital market for in Dye's model. Second, as already noted, modeling investors as risk-averse is not critical to Dye's conclusion that mandatory disclosure in the presence of interfirm externalities need not increase disclosure compared to a voluntary regime, the conclusion that goes to the heart of Fox's rationale of mandatory disclosure. Of course, underlying modern finance theory is the behavioral assumption that investors are risk-averse; that is why diversification is important. Thus, as a matter of theory, the model's assumption of risk-averse investors and entrepreneurs is entirely unobjectionable.

${ }^{108}$ Fox objects to modeling investors as risk-averse because the CAPM suggests that investors should not be concerned about firm specific risk, Fox, supra note 3, at 1349, an objection that is inconsistent with other arguments in his article. For example, while he relies on the behavior of investors predicted by the CAPM to object to Dye's stylistic set-up, when it is inconvenient for his position, he reverses course and rejects the CAPM in order to dispute my assertion regarding the behavior of institutional investors with respect to the choice of disclosure regime that undermines his contention regarding the need for a single regulator's mandatory disclosure regime. It should also be noted that CAPM is premised on risk-averse investors. In fact, in Dye's model, investors diversify their holdings across the firms in the economy, as do CAPM investors; Dye does not, however, separate firm and market risk, which is a key contribution of the CAPM to finance theory and the motivation for Fox's line of argument. Of course, the premise of the U.S. disclosure regime that Fox is defending in his article is inconsistent with CAPM, as it is directed to disclosure of firm-specific information and not information about the firm's sensitivity to market risk. It is thus puzzling, to say the least, that Fox raises this particular objection to Dye's model.

${ }^{109}$ Dye, supra note 84 , at 19.

${ }^{110}$ Fox, supra note 3, at 1348-49.

${ }^{111}$ See Michael C. Jensen \& William H. Meckling, Theory of the Firm: Managerial Behavior, Agency Costs, and Ownership Structure, 3 J. Fin. Econ. 305 (1976).

${ }^{112}$ E.g., Fox, supra note 13, at 2545-48 (relating securities disclosure to reducing agency costs in relation to the market for corporate control); Fox, supra note 3, at 1355 (discussing agency costs); id. at 1349 (citing agency costs theory to criticize Dye's model). 
Treating the firm's disclosure choice as a commitment to the accuracy of subsequently disclosed information and hence as a risk-shifting device also is not a completely unrealistic assumption. Fox is surely correct that the components of a disclosure policy can be manifold, and Dye's model, to be tractable, models only one such possibility, which may not be the principal component of the SEC's regime. It is a sensible object of a disclosure policy in the context of a risk-shifting game, where insiders, who are making the disclosure choice, as well as investors, use the capital market to perform its essential function to diversify their holdings (that is, to reduce risk). While Dye's specific entrepreneurial investment game may be too stylized to be generalizable to all disclosure settings, Fox offers no basis for believing that a model of disclosure policy in which securities transactions are undertaken for reasons other than risk-shifting would produce a result different from Dye's model. Moreover,

the risk that is reduced by disclosure in Dye's model is systematic risk (that is what an interfirm externality is all about—one firm's disclosure affects the value of all other firms in the economy) and not, as Fox mistakenly contends, unsystematic risk. Hence, disclosure policy in Dye's model effects prices. It is therefore difficult to fathom Fox's claim that Dye's risk-shifting modeling choice invalidates the model. ${ }^{113}$ Disclosure policies that relate to risk reduction and risk shifting when that risk is systematic and therefore affects stock prices are relevant in the real world, and hence the model is as well. $d$. Is the interfirm externality from disclosure a positive externality? Besides his objections regarding the model's structure, Fox claims that the direction of the correlation in returns from disclosure is not open-ended, as it is in Dye's model. ${ }^{114}$ This is a key objection for Fox because it is the open-endedness in the direction of the correlation that produces the model's result regarding the ambiguity in the efficacy of mandatory disclosure, and this result is the basis for my reference to the model as suggesting that Fox's position is not theoretically well-grounded. Fox asserts that the effect is always negative on the firm and always positive on the market (in the model, a positive correlation), which is the one case in

${ }^{113}$ Fox, supra note 3, at 1347-49. Indeed, Fox contradicts himself at this point, as he later contends that reduction of risk was the essential benefit provided by the mandatory disclosure regime created by the U.S. government in the 1930s. E.g., id. at 1375. I discuss whether this is an accurate interpretation of the data on the effect of the federal securities laws in infra Part III.C. Fox's mistaken interpretation of those data is integrally related to his mistaken conclusion concerning the realism of Dye's disclosure model, which, as noted in the text, is a mix-up between firm-specific risk and market risk in Dye's model. The reduction of risk in Dye's model is not related to Fox's subsequent argument concerning the impact of the 1933 and 1934 Acts because in the model, the disclosure policy involving the accuracy of the estimate of returns affects stock prices (i.e., the risk in Dye's model is market risk), and this results in shifting risk across investors (insiders and outsiders). The disclosure policy of the 1930s legislation did not affect stock prices and only affected the variance of total returns (unsystematic or firm-specific risk). Fox rightly points out that firm-specific risk is not of interest to investors under modern finance theory, but he ignores this same point in discussing the impact of the federal legislation.

${ }^{114}$ Fox, supra note 3, at 1350 n.25. 
Dye's model in which mandatory disclosure does better than voluntary disclosure. ${ }^{115}$ Notwithstanding Fox's assertion that the direction is always positive, it is also quite possible that the market-wide effect is negative and the effect on the disclosing firm could be either negative or positive.

Without the benefit of a formal model such as Dye's, it is exceedingly difficult to pinpoint the source of Fox's position regarding the efficacy of mandatory disclosure as dependent upon an assumption regarding the direction of the correlation of returns of firms with respect to a disclosure. Fox does not formally model the relation and instead provides a plot of private and social marginal cost and benefit curves in which the social cost curve always lies below the private cost curve and inversely for the benefit curves. ${ }^{116}$ There is no unambiguous theoretical basis for this location of the curves; this location is correct only if it is assumed that the interfirm externality is positive. The difficulty with Fox's diagram can be illustrated with two simple examples involving a regime requiring disclosure of information regarding new product discoveries and future business plans.

When Computerco announces that it has patented a new microprocessor that will make its computers thirty times faster than existing machines, this announcement will increase the stock price of Computerco and reduce the stock price of its competitors. This piece of information has higher private benefits than social benefits. When Steelco announces that it has acquired property in West Virginia on which it plans to build a large production plant that will triple its capacity, regardless of the effect of this information on Steelco's stock, it will deter competitors' entry or similar expansion into the steel market (and if that would have been a profitable course of action, it will result in a decrease in their stock prices). ${ }^{117}$ Although this disclosure is the epitome of an interfirm externality-it provides crucial information to competitors-its release will have an adverse impact on social welfare by reducing competition and thereby raising steel prices. Fox's diagram rules out these cases because he chooses to define interfirm externalities as information that benefits other firms rather than information that can have either a positive or a negative effect on other firms.

If Fox is truly interested in formulating a securities regime that maximizes social welfare in the context of interfirm externalities, then he must factor in all externalities, positive and negative. Maximizing social welfare when the impact of all externalities is considered does not lead to a policy that maximizes the amount of disclosure as Fox's analysis suggests. Rather, it will require restricting disclosures such as Computerco's discovery that

${ }^{115}$ Id. at 1350 .

${ }^{116} \mathrm{Id}$. at 1345 .

${ }^{117}$ There is an extensive economic literature regarding firms' use of credible commitments in the form of sunk costs that expand capacity in order to limit competition. See, e.g., B. Curtis Eaton \& Richard G. Lipsey, Capital, Commitment and Entry Equilibrium, 12 Bell J. Econ. 593 (1981). The liability rules for fraudulent disclosure under the securities laws materially assist firms in engaging in such a strategy: if Steelco has no intention of building the plant, it can be sued for substantial damages under the securities laws. For an excellent discussion of such an effect of the securities laws - how firms can exploit the disclosure rules to gain strategic advantages over competitors-see 
have a negative impact on other firms that is greater than the benefit to the disclosing firm's shareholders, even though the information would be important to investment decisions regarding shares in the affected firm, as well as prohibiting preemptive disclosures that will reduce competition, such as Steelco's plant expansion plans. Although this is a result surely counterproductive from the conventional understanding of the goal of a disclosure regime (disclosure of material firm-specific information to assist in the decision to invest in the firm's shares), it would be the appropriate outcome under Fox's regulatory approach, which requires consideration of interfirm externalities in the formulation of policy. Therefore, it is intellectually incoherent for Fox to ignore negative externalities and consider only positive externalities if the regulatory goal is, as he states, social welfare maximization and not simply maximization of the amount of information disclosed by firms.

I have so far provided only hypothetical examples of a negative externality. I have done so to suggest that notwithstanding Fox's claim that "it is hard to imagine how, as an ordinary matter, a disclosure by one issuer would have a negative effect on the aggregate cash flows of all the other firms," ${ }^{118}$ there are quite common scenarios in which the disclosure of information regarding one firm can drive down the value of all of the firms in the industry. Moreover, such scenarios are not merely hypothetical. Empirical support for this contention regarding the direction of the correlation can be found in stock price studies that indicate disclosure of adverse events experienced by one firm in an industry, such as product tampering, airplane crashes, product liability litigation or product recalls, on occasion have negative stock price effects on rival firms. ${ }^{119}$ It is therefore not at

Marcel Kahan, Games, Lies, and Securities Fraud, 67 N.Y.U. L. Rev. 750, $780-82$ (1992).

${ }^{118}$ Fox, supra note 3, at 1350 n.25.

${ }^{119}$ See, e.g., Mark L. Mitchell, The Impact of External Parties on Brand-Name Capital: The 1982 Tylenol Poisonings and Subsequent Cases, 27 Econ. Inquiry 601, 616 (1989) (documenting substantial stock price losses to Tylenol manufacturer after product tampering, as well to all over-the-counter drug marketers); Severin Borenstein \& Martin B. Zimmerman, Market Incentives for Safe Commercial Airline Operation, 78 Amer. Econ. Rev. 913, 931-32 (1988) (small but significant negative price effect and demand effect after ten large plane crashes on rival firms); David Prince \& Paul H. Rubin, The Effects of Product Liability Litigation on the Value of Firms (Emory Univ. Dep't of Econ. Working Paper No. 00-08, Apr. 2000) (finding product liability litigation for firms in automobile industry had negative stock price effect on competitors, whereas such litigation for firms in pharmaceutical industry did not); Gregg Jarrell \& Sam Peltzman, The Impact of Product Recalls on the Wealth of Sellers, 93 J. Pol. Econ. 512, 521, 532 (1985) (finding drug and auto recalls have negative stock price effects on stock prices of competitors of producer of defective product); David Dranove \& Chris Olsen, The Economic Side Effects of Dangerous Drug Announcements, 37 J.L. \& Econ. 323, 331 (1994) (significant negative stock price effect on competitors as well as manufacturer of recalled drugs in the 1960s). However, some researchers have not found statistically significant spillover effects from product recalls in contrast to Jarrell and Peltzman's findings. See George E. Hoffer et al., The Impact of Product Recalls on the Wealth of Sellers: A Reexamination, 96 J. Pol. Econ. 663 (1988) (finding no price effect on firm subject to recall or on competitors for a subset of Jarrell and Peltzman's automobile recalls they considered cleaner because recall overlaps were eliminated as were government actions not deemed true recalls); Brad M. Barber \& Masako N. Darrough, Product Reliability and Firm Value: The Experience of American and Japanese Automakers, 1973-1992, 104 J. Pol. Econ. 1084 (1996) (examining automobile recalls over a longer period than Jarrell and Peltzman and including Japanese firms and finding negative price effect on firm subject to recall but no effect on competitors). Although Dranove and Olsen find significant negative stock price effects on competitors from drug recalls in the 
all "out of the ordinary," as Fox contends, to consider that there can be negative, as well as positive, externalities from one firm's disclosures.

Although expending a great deal of effort, Fox provides no explanation why it should be assumed that the information that is relevant to third parties that will be disclosed under a mandatory regime will constitute only good news to rivals (such as information indicating wide profit margins and hence market opportunities), as opposed to bad news (such as information indicating the business is not as profitable as believed). Just because Fox defines an interfirm externality to be a positive externality does not make it so. Disclosure of information regarding costs or policies that bear on a firm's profit margins cannot be assured to have a positive, as opposed to negative, impact on competing firms' returns.

Finally, it is altogether possible that in the case of a positive externality, the harm to the disclosing firm would be greater than the benefit to rival firms from disclosing information. If this were the situation, then the social welfare maximizing policy would not be to mandate disclosure. In this scenario, Fox should not call for disclosure, although this conclusion is far from certain because he has defined away such possibilities. To the extent that this is true, however, Fox's analysis does not provide a reason why a government regulator would be able to make this laborious calculation correctly for each piece of information for each firm. Moreover, realworld disclosure regimes do not prohibit the disclosure of information that could adversely affect other firms. I will return to flesh out this theme- the inadequacy of U.S. disclosure regulation as a means of correcting interfirm externalities - as an empirical matter. ${ }^{120}$ The point here is to explain why Dye's article is pertinent: It indicates that Fox's regulatory rationale works only if the externality is in the direction that he posits for all information for all firms. Dye's model thus highlights the enormous burden Fox's position would place on a regulator. A regulator would have to be able to estimate the impact that information will have on the returns of the disclosing firm and all other firms, in order to get a mandatory disclosure policy right.

Without question, firms have stronger incentives to release voluntarily information generating negative rather than positive externalities. Although Fox insists that there is only one direction (positive) in which interfirm externalities can arise, he could have taken the position that a mandatory regime cannot solve the negative externality problem of over-disclosure by firms of items that harm rivals (unless it prohibits such disclosures), but can do something about the positive externality problem of under-disclosure by firms of items that benefit rivals.

1960s, they do not find a decline in competitors' actual drug sales after the recalls, and examining only a subset of Jarrell and Peltzman's drug recalls in the 1970s (7 of 26), they find the negative return to competitors is insignificant. This leads them to conclude that the competitor stock price effect is due to investors' anticipation that the cost of compliance with drug-testing regulation would increase in the 1960s and not a true spillover effect.

${ }^{120}$ See infra Part III.B.3. (analyzing whether the SEC regime effectively discloses information bearing on competitors' positions). 
However, even if he had adopted this position, recasting his thesis along these lines would not avoid the extraordinary burden placed upon a regulator from the interfirm externalities rationale: disclosure policies still cannot be uniform for firms (as they are under current regimes), but have to require different issuers to reveal specified items, according to their impact on competitors. It is difficult to conceive of a functioning regulatory scheme so finely honed to mandate disclosure solely of positive externalities.

e. Even if the interfirm externality is positive, is disclosure regulation always welfare-improving? The formidable difficulty of a regulator getting disclosure policy right in the context of interfirm externalities is also the source of the ambivalent normative position on mandatory disclosure in the article by Admati and Pfleiderer, the only other article I could find that models disclosure in the context of interfirm externalities. ${ }^{121}$ Admati and Pfleiderer's objective is precisely to model Easterbrook and Fischel's suggested rationale for a mandatory regime - the presence of an externality not internalized by individual firms (represented as in Dye, by a correlation in firm values) - that would justify a role for disclosure regulation. ${ }^{122}$ In their model, Admati and Pfleiderer assume that the correlation is positive, ${ }^{123}$ but they obtain similar results to Dye's model that make it impossible to conclude that disclosure regulation can be designed that will unambiguously improve social welfare, even if the correlation is, as Fox maintains, only in one direction, positive.

In addition to the assumption that there are interfirm externalities of relevance to disclosure policy, Admati and Pfleiderer's model has the following features: disclosure is costly, ${ }^{124}$ and in particular, there are economies of scale in disclosure such that there is a discontinuity or threshold effect that causes firms' disclosure to jump from nothing to a lot; and there are information asymmetries between firms and investors that reduce firm valueis, in contrast to Dye's model, there is private information. As does Dye, they abstract away the possibility of false disclosures and assume any disclosed information is truthful. They justify the assumption of truthfulness similarly to the rationale offered concerning the realism of Dye's commitment assumption: rules against fraud are

${ }^{121}$ Admati \& Pfleiderer, supra note 85.

${ }^{122}$ Id. at 480.

${ }^{123}$ Because in their model, the absolute value, rather than sign, of the correlation coefficient affects firms' interactions, although they treat the correlation coefficient as if it were positive throughout the article, technically their results would hold as long as the correlation coefficients have the same absolute value. Id. at 493.

${ }^{124}$ It should be noted that in this regard, their model is more realistic than Fox's argument, which never seriously ascribes a cost to firms' disclosure. Fox provides an extended discussion of the social benefits of disclosure, but gives no consideration to the possibility that there is a social cost to disclosure; there is only a reference, passed off in a paragraph, that disclosure entails solely "private" costs, which are asserted to be lower than the social gain, and thus he never discusses the need for a tradeoff; disclosure is assumed always to entail a net benefit. Fox, supra note 3, at 1345-46, 1356-59. In an earlier article, he again emphasizes the social benefits of disclosure, considers the costs as essentially private, but adds a perfunctory sentence at the end of the discussion that the proper calculation of the welfare effects includes balancing all benefits and costs. Fox, supra note 13 , at 2552 . 
enforced, and third parties for whom a truthful reputation is important, such as accountants, often make the disclosures. ${ }^{125}$ Finally, like Dye's model, theirs is a single-period model.

Admati and Pfleiderer's model has, however, two important differences from Dye's model that should render it more acceptable to Fox. First, investors are modeled as risk-neutral, and second, the benefit of disclosure is not risk-shifting but reduction in information asymmetries between the firm and investors. ${ }^{126}$ Both of these features eliminate objections that Fox directed at Dye's model: Dye's treatment of the benefit from disclosure as the transfer of risk between entrepreneurs and investors and his modeling of investors as riskaverse. $^{127}$

Admati and Pfleiderer first investigate a voluntary disclosure game in which firms decide what to disclose. As in Dye's model, disclosure policy involves the level of precision at which the firm will provide information about its value, and it is selected before the firm knows its value. ${ }^{128}$ This timeline assumption is also interpreted non-temporally: the disclosure choice is made independent of value such that the firm cannot change its disclosure choice when it learns its value. In contrast to Dye's model, however, the firm alone knows its own true value; the disclosed signal is the only credible information the firm can provide to investors concerning its value. As Admati and Pfleiderer note, the model could be extended to a situation in which the firm does not learn the true value of its cash flows, but obtains a signal of that value instead, without affecting the results. ${ }^{129}$ Although firms' disclosure choices are unaffected by their knowledge of their valuations, their stock sales are not; if investors will not pay a sufficient price given the signal, a firm does not sell its shares.

This feature of the model - the choice of disclosure before knowledge of firm value or, alternatively, the treatment of the disclosure choice as independent of firm value-would presumably be unsatisfactory to Fox, as he finds such a setup objectionable in Dye's model. Admati and Pfleiderer justify the notion that the firm cannot change its chosen disclosure policy given the realization of its value as reasonable by noting that it is costly and time-consuming for a firm to create a disclosure system, such as hiring an accountant "to produce a report or certify the disclosure made by the firm." ${ }^{130}$ They further note that if the choice of disclosure is modeled as dependent on the firm's value, then the resulting complex signaling game is not easily solvable: there are no pure strategy equilibria; and if there are equilibria, they have unintuitive properties, and in such a context one cannot

\footnotetext{
${ }^{125}$ Admati \& Pfleiderer, supra note 85 , at 481. They also note that this is the standard assumption in the economics literature on disclosure.

${ }^{126}$ Id. at 483.

${ }^{127}$ Fox, supra note 3, at 1348-49.

${ }^{128}$ Admati \& Pfleiderer, supra note 85, at 484.

${ }^{129} I d$. at 484 n. 8 .

${ }^{130} \mathrm{Id}$. at 485 .
} 
analyze disclosure regulation, such as setting minimum precision requirements. ${ }^{131}$

The core result of the model is that regulation is not always optimal. The level of individual firms' disclosure when disclosure is voluntary is less than the socially optimal disclosure level when the correlation of firm values is high, suggesting a role for regulation that sets a minimum disclosure level. ${ }^{132}$ But when the correlation in value is low, the level of voluntary disclosure does not differ from the social optimum, and hence there is no role for regulation. ${ }^{133}$ Moreover, the result regarding the benefit of regulation holds unambiguously only when firms are identical (that is, when they are symmetrical in sale value and disclosure cost). If symmetry does not hold (so that the costs and benefits of disclosure vary across firms), then while it is still generally true that voluntary disclosure is optimal for low correlations and regulation is superior for high correlations, the disclosure requirement must, in fact, be specific to the different firms in order for regulation to produce a higher level of welfare than voluntary disclosure. ${ }^{134}$ This is because the socially efficient outcome is no disclosure for some firms and disclosure for other firms, depending on their varying costs of disclosure. If, as occurs in the real world of securities regulation, the disclosure standard must be uniform across all firms, then because all firms are not identical in the costs and benefits that they accrue from disclosure, regulation will not necessarily improve the situation compared to voluntary disclosure and may, in fact, be unambiguously worse. ${ }^{135}$

Admati and Pfleiderer next examine an alternative form of government intervention to mandatory disclosure regulation: provision of uniform cash subsidies to firms, which reduce the cost of disclosure and, hence, alter firms' incentives to disclose. They provide an example, in the context of asymmetrical firms, in which subsidies can move firms to the socially optimal level compared to voluntary disclosure and disclosure regulation, if the subsidies are chosen appropriately. ${ }^{136}$ This is a big if, however. The result does not hold generally, and while in some cases subsidies can improve social welfare, in others they cannot. ${ }^{137}$ Admati and Pfleiderer thus conclude that they are unable to recommend one form of government intervention over the other. ${ }^{138}$ Their nuanced position is, again, sharply at odds with Fox's claim that interfirm externalities require mandatory disclosure.

I have devoted considerable space to discussing the formal models that have investigated the choice of disclosure regime in the presence of interfirm externalities. This is not because the models are precise portraitures

${ }^{131}$ Id. at 485 n.9.

${ }^{132}$ Id. at 499-500.

${ }^{133} I d$. at 500. In addition, the role for regulation is greater as the number of firms increases, for at lower numbers, the externality is small and the social optimum may not call for disclosure. Id. at 501-03.

${ }^{134}$ Id . at 503-04.

${ }^{135} \mathrm{Id}$. at 505-09.

${ }^{136} \mathrm{Id}$. at $509-12$.

${ }^{137} \mathrm{Id}$. at 512 . 
of the world; they are not. The modeling issues would become intractable were all institutional complexitiessuch as endogeneity in the choice of signal, the number of shares to be issued, and the value of the firmintroduced. But models that incrementally add complexity invariably increase the ambiguity of the results of simpler models, because as earlier noted, the greater the complexity of a model, the more restrictive must the assumptions be to obtain any equilibria, the more likely is the possibility of multiple or no equilibria, and hence the less probable it is that the model will be able to produce any determinate policy conclusions. This is what Admati and Pfleiderer found to be the case in preliminary efforts to extend their model on only one dimension, namely, conditioning the choice of signal on firm value. ${ }^{139}$ There is, accordingly, one conclusion that can be drawn assuredly from the results of the two models of disclosure policy in the context of interfirm externalities, and this is the reason for reviewing the models in considerable detail: it is inappropriate to assert with any appreciable confidence, particularly the certainty that Fox conveys, that government intervention to mandate disclosure in order to remedy interfirm externalities will always maximize social welfare. Fox has committed a common fallacy of disclosure market-failure proponents, which Harold Demsetz terms "the grass is always greener fallacy" and which, he explains, occurs because the proponents assume that the government alternative achieves the optimal output without examining that government alternative as closely as they scrutinize market outcomes. ${ }^{140}$

\section{Diversified Investors and Interfirm Externalities}

Institutional investors holding diversified portfolios could internalize any relevant interfirm externalities so that a competitive regulatory regime could successfully resolve interfirm externalities were that the rationale for securities regulation. Fox attempts to refute this contention, which supports regulatory competition under his rationale for securities regulation, by asserting that investors do not hold more than one firm in an industry. ${ }^{141} \mathrm{He}$

${ }^{138} I d$.

${ }^{139}$ See supra note 131 and accompanying text.

${ }^{140}$ See Harold Demsetz, Information and Efficiency: Another Viewpoint, 12 J.L. \& Econ. 1 (1969).

${ }^{141}$ Fox, supra note 3, at 1352. After making this assertion, citing a textbook by Gilson and Black for the proposition that a judicious choice of twenty stocks achieves efficient portfolio diversification for support (although there is no evidence that any diversified institutional investor holds only twenty stocks or only one firm in any industry sector), Fox states that the only investors who would internalize externalities would be index-funds and they "are notoriously passive concerning corporate governance." Id. at 1352 n.30. Fox is again incorrect. Four of the five most active institutional investors in corporate governance are the pension funds of the State of California and New York City, TIAA-CREF, and the State of Wisconsin Investment Board; the first three institutions are mostly indexed funds, while only the last one, the State of Wisconsin Investment Board, is an active stock picker. See Diane Del Guercio \& Jennifer Hawkins, The Motivation and Impact of Pension Fund Activism, 52 J. Fin. Econ. 293, 297, 301 (1999). Moreover, more recent work suggests that investors need to hold significantly more than 20 stocks, between 50 and 100, to achieve portfolio diversification, given the increase in market volatility since 1960. See Lynn Cowan, Unwise Wisdom: 14. A 20-Stock Portfolio Gives You All the Diversity You Need, Wall St. J., Jan. 29, 2001, at R16 (citing several finance studies finding 50 stocks necessary to achieve portfolio diversification to match risk posed by 
is incorrect. The vast majority of institutional investors, including the major market players, such as TIAA-CREF, the California Public Employees Retirement System ("CalPERS"), and the largest funds in the Vanguard Group of investment funds, hold significant portfolios indexed to the Standard and Poor's 500 and Wilshire 5000 indexes, which include numerous firms in each industry sector of the United States, not to mention the many sector funds that specialize in specific industries. Therefore, in contrast to an issuer, investors can internalize information externalities regarding disclosure policy, just as a regulator can. That is, investors who hold portfolios will desire a regime requiring such information's disclosure (if Fox's disclosure rationale is correct) because by the definition of a positive externality, the loss on their shares in the disclosing firm will be offset by the gain on their shares in the discloser's competitors.

Fox further asserts that portfolio diversification is irrelevant to an investor's assessment of the disclosure regime for a firm initially going public ("IPO" firm). ${ }^{142} \mathrm{He}$ provides an example in which there are investors in only one of two firms, an IPO firm (firm "A") and a trading rival (firm "B"), and maintains that in these circumstances the investors in the IPO firm cannot be benefited by the impact of its disclosure on the rival firm because this will hurt A's stock price. But he does not advance any explanation for why B investors, who would ostensibly be benefited by A's disclosure more than A would lose, a criterion for this to be a social-welfare maximizing disclosure, would not buy the A shares to guarantee that it makes the correct disclosure choice. Fox simply posits that B shareholders cannot purchase A shares and thereby affect the disclosure regime because it is a public securities market. Furthermore, the premise of the example is odd because institutional investors do not hold the shares of only one IPO firm (which would be a foolhardy strategy) or only one non-IPO firm, nor would a disclosure regime be likely to be applicable only to one firm under regulatory competition. In addition, Fox is assuming that the externality benefit goes only one way, from firm A to firm B (that no information about firm B could ever benefit firm A). If it goes both ways, then the diversified investors (who, in the two-firm economy, will hold both firms' shares) should want both firms to select the same, interfirm externality-revealing disclosure regime.

Moreover, underwriters and the institutional investors to which they sell shares are, in contrast to Fox's hypothesized investors, repeat players in the new issue market, as well as active players in the secondary trading market. An IPO placement is not an anonymous market transaction; underw riters test the market for an IPO with numerous institutional investors in advance of setting a price to guarantee the issue will sell. As a consequence, the choice of a securities regime will be negotiated by underwriters, who must be responsive to their repeat

holding 20 stocks 30 years ago and over 100 stocks necessary to achieve portfolio whose risk is within $5 \%$ of average risk).

\footnotetext{
${ }^{142}$ Fox, supra note 3, at 1351.
} 
institutional customers, and issuers, just as the choice of statutory domicile is of interest to them in the current regime. ${ }^{143}$ Thus, in the environment of a competitive securities regulatory regime, institutional investors and market intermediaries will consider the impact of the disclosure regime on all of their investments, not only for one IPO investment, and their valuations of the different regimes will be reflected in the firms' stock prices. If, in fact, in a competitive regime, investors do not prefer regulation that mandates disclosure of the kind of information that Fox deems relevant for interfirm externalities, then that would be suggestive, due to revealed preferences, that Fox is mistaken and has miscalculated the cost-benefit calculation; that is, the cost to a disclosing firm is greater than the gain to its competitors.

Fox also claims that investors in secondary markets have "tenuous" influence over management, being overwhelmed with "vast information asymmetries" and "collective action problems." 144 This is another mistaken contention. Perhaps this was true of the 1934 stock market when the federal securities laws were enacted, but this is certainly not true today. The stock market is dominated by institutional investors who are sophisticated repeat players, and there are organizations that coordinate policies on corporate governance for institutional

${ }^{143}$ Firms that go public move in overwhelming numbers to Delaware before the stock issuance; surveyed firms indicate that the move was suggested by outside counsel and, to a lesser extent, investment bankers, and venture capitalists and leveraged buyout specialists appear to prefer Delaware. See Romano, supra note 21, at 250, 274 (data on reincorporation before going public and survey of reincorporating firms); Robert Daines, Does Delaware Law Improve Firm Value? 16 (Columbia Law Sch. Ctr. for Studies in Law \& Econ. Working Paper No. 159, Nov. 1999) (data on incorporation choices of initial public offerings and of venture capitalists and leveraged buyout firms), available at SSRN Electronic Paper Collection, http://papers.ssm.com/sol3/papers.cfm?abstract_id=195109. In discussing the question whether domicile choice was of concern to a venture capital-supported firm about to go public, participants from the venture capital industry at the University of Pennsylvania Law and Economics Institute Roundtable on May 12, 2000, indicated quite unambiguously that it was desirable for the company to be incorporated in Delaware for the offering. Moreover, as previously noted, many of the most activist investors in corporate governance are primarily indexers, such as, the California Public Employees Retirement System, California State Teachers Retirement System, New York City Employees Retirement System, and TIAA-CREF. See Del Guercio \& Hawkins, supra note 141, at 297, 301 (CalPERS, CalSTERS, NYCERS, SWIB, and CREF sponsored 18\% of all corporate governance proposals submitted in 1987-1993; only SWIB is an active stock picker). All of these facts are inconsistent with Fox's claim that because indexed funds "notoriously" do not engage in corporate governance, they would not care about the choice of legal regime. Fox, supra note 3, at 1352 n.50.

${ }^{144}$ Fox, supra note 3, at 1352. Alan Palmiter raises a similar concern, distinguishing secondary trading from initial offerings, because he thinks managers are less responsive to investor demands in that context, in justification of his proposal to permit the choice of disclosure regime for new issues but not for the regime applicable to those issuers' ongoing disclosures. See Palmiter, supra note 22, at 91, 106. As discussed in the text above and infra part II.C.4, similar incentives exist for managers to respond to investor preferences concerning information production in secondary markets as in initial offerings: for instance, disclosing the information that investors desire will avoid largescale selling by institutions that would depress the firm's stock price and could thereby attract a hostile takeover bid (or avoid the personal discomfort managers experience from the pressure applied by the proxy activism of non-selling indexed institutional investors). It is also a mistake to distinguish, as Palmiter does, across the disclosure regimes in secondary and initial trading markets under regulatory competition, because the investors who direct the choice of the IPO regime will be aware that the same regulator's ongoing disclosure policy will apply to the firm. Consequently, the choice of the ongoing disclosure regime will be embedded in the choice of the regime for the IPO. 
investors that largely mitigate potential collective action problems regarding information gathering and action with respect to firms. Moreover, the sources of information in today's markets for investors are extensive: besides substantial internal resources for private research, financial analysts and other information services abound, and there is a growing amount of investment information available on the Internet, making it accessible even to individual investors. It is not credible to conclude that in this context institutional investors are at a severe disadvantage in assessing the value of a firm such that they cannot possibly correctly assess the value of a legal regime under which a firm chooses to operate. Nor is it credible to assert that the development of this infrastructure is dependent upon the SEC's disclosure policy and would therefore vanish in the absence of a single regulator.

Fox concludes his critique of the contention that diversified investors can internalize interfirm externalities with two strange arguments. He first contends that it would be a breach of fiduciary duty for managers of firms to choose a disclosure regime that benefits a rival firm. ${ }^{145}$ This contention is groundless. Since investors prefer the regime, by choosing it, the firm reduces its cost of capital, and there would be no basis for a lawsuit. As a doctrinal matter, the choice of a disclosure regime is a matter of business judgment, as there is no self-interest (breach of loyalty) issue involved in the selection of a regime that includes items relating to interfirm externalities. Moreover, purchasers of IPO or secondary market shares buy shares in a firm already operating under a particular regime. Consequently, they would not have a valid claim of fiduciary breach for reduced share value due to the preexisting regime choice: the "breach" occurred before they purchased their shares, and hence they have no standing to bring a derivative claim. Indeed, because investors know the regime under which the firm is operating at the time of purchase, if the regime reduces the value of their investment, they will pay less for the shares. Hence, even if a shareholder could circumvent the standing issue by contending that the claim is not derivative in nature, there would be no damages.

Second, Fox contends that if it is correct that the disclosure of interfirm externalities will be priced by investors and, therefore, as resolvable by a competitive securities regime as by a single regulator, then the necessary conclusion is that there must be no sanctions for patent and contract breach by firms because such behavior negatively affects other firms. ${ }^{146}$ This argument is ridiculous. Perhaps under Fox's approach of

$145 I d$. at 1352 n.31. Given this criticism, then, the regime that Fox contends is the present SEC disclosure regime is one that requires managers to breach their fiduciary duty. I seriously doubt that either the SEC or Congress perceives the regime in this light, an intuition that suggests that Fox's characterization of the objective of the SEC's regime is misguided (and not simply that his argument is unfounded). Indeed, if his contention regarding management's duty were correct, at least under a competitive regulatory regime, investors would agree to the misconduct by their choice of a regime requiring such disclosure, in contrast to Fox's approach, which imposes on investors the regime that results in a breach of duty.

${ }^{146} I d$. at 1353. 
maximizing social welfare, cross-holdings of investors should be factored in when determining liability in such cases. But this is irrelevant to the hypothesis that diversified investors will be able to internalize the costs and benefits of interfirm disclosures as well as Fox's preferred single regulator. Institutional investors' ability to perform the cost-benefit calculation on corporate disclosure just as well as the SEC has absolutely no implication for the liability rules for patent infringement and contract breach, and it is a mystery how Fox could possibly make such a connection. The contention that investors can internalize disclosure externalities follows from the point that it is investor preferences that dictate regime choices under regulatory competition and that in contrast to issuers, investors are in a position to behave identically to Fox's single regulator and internalize the social costs and benefits of an individual firm's disclosures. ${ }^{147}$ Were society to determine that the aim of the patent and contract regimes should be to maximize shareholder welfare, then corporate choice of those regimes might make sense; providing corporations with these regimes' choices under the reformulated objective would depend upon whether there are significant third-party effects that would not be included in the cost-benefit calculus undertaken by diversified investors.

${ }^{147}$ It is exceedingly odd that Fox thinks that the claim regarding the equivalency of disclosure choices in multiple and single securities regulator systems where investors are diversified somehow dictates how judges should decide patent or contract claims. The patent regime is not directed at maximizing in vestor welfare but at maximizing innovation, and it is premised upon providing incentives to invention by guaranteeing inventors a return on their efforts through a monopoly of limited duration, in exchange for public disclosure so that their ideas can be used by other inventors. See generally Edmund W. Kitch, Patents, in 3 The New Palgrave Dictionary of Economics and the Law, supra note 24, at 13. Whether investors in the inventor's firm also hold shares in the infringer is irrelevant to this statutory objective and hence would not be judicially cognizable. If there were enforceable competition in patent regimes, investors might take a broader view of infringement, but the desirability of competition in securities regulation does not translate into its efficacy for other legal regimes where there may be substantial third-party effects not internalized by the selectors of regimes, which is not the case of equity investors and securities law. In other words, maximization of shareholder welfare, which would be the objective of a competitive regime selected by investors, may not maximize innovation or, to be more precise, social welfare in the context of innovation policy. It is impossible to discern what Fox has in mind when he claims that the abandonment of sanctions for breach of contract follows from the thesis that a single regulator is not superior to competition when investors can internalize the costs and benefits at stake in the disclosure of interfirm externalities. Investors do not choose the regimes that govern firms' business contracts - this is a matter of ordinary business judgment in management's discretion-nor would they desire to make such a decision, as they would not have any expertise on the relevant issues. They do, however, choose a firm's securities law in a competitive regulatory environment, because firms that disregard investor preferences will have a higher cost of capital. Perhaps Fox is suggesting that investors' welfare would be maximized by firms' selecting for their business contracts a jurisdiction that does not impose sanctions for breach when there is overlapping ownership of the breaching and breached firms and that firms should adopt such choice-of-law clauses. It is not self-evident, however, given the complicated interplay of incentive effects surrounding breach and the measure of damages, which has been the subject of extensive commentary, see, e.g., Aaron S. Edlin, Breach Remedies, in 1 The New Palgrave Dictionary of Economics and the Law, $i d$. at 174, whether share values would be maximized by such an approach and, correspondingly, whether diversified shareholders would benefit from a regime that does not sanction breach of contract as Fox asserts. But if there is a substantial overlap of ownership across contracting parties, it is possible that there will not be litigation over a contractual breach in the first place (the owners with cross-holdings might prod management to renegotiate the contract rather than litigate). 
In sum, the source of Fox's error in concluding that only a monopolist government entity can internalize the costs and benefits of disclosure involving interfirm externalities is his exclusive focus on the incentives of issuers rather than those of investors, whose holdings are diversified and whose preferences will dominate the choice of securities regime under regulatory competition. In a competitive securities regime, issuers' choices of their securities domicile are guided by investor preferences, as this reduces their cost of capital. Consequently, if disclosure of interfirm externalities is cost-effective (the gain to rival firms exceeds the cost to the disclosing firm), then investors will desire such disclosures and they will be a component of the prevalent securities regime. While it is possible that some investors might overvalue the harm to a disclosing firm compared to the gain to its competitors in that cognitive psychology suggests losses figure more prominently in an individual's calculus than gains, ${ }^{148}$ it is implausible that such behavior will prevail systematically in decisions where significant dollars are at stake for sophisticated repeat players such as institutional investors. Moreover, there is no reason to believe that the staff of a single government regulator would make fewer mistakes than sophisticated market participants with substantial wealth at stake in getting the disclosure system correct.

Finally, it should be noted that whether investors or an agency internalizes the costs and benefits of interfirm externalities, there is a further reason why social welfare is not self-evidently maximized with the disclosure of interfirm externalities. The disclosures that Fox advocates are the objective of mandatory disclosure --information regarding firm-level costs and profit margins-- are data that facilitate collusion and, hence anticompetitive behavior. This is, of course, the reason for the longstanding prohibition against firms' informationsharing under the U.S. antitrust regime.

\section{Does the SEC Require Disclosure of Information regarding Interfirm Externalities?}

The third and most important critique of the interfirm externalities rationale for a single regulator securities regime is that the SEC's mandated disclosure does not, and cannot, in practice require firms to disclose private proprietary information such that the released information will significantly assist competitors. In response, Fox states that "almost all potential corporate disclosures have interfirm costs" and that such disclosure is the focus of numerous items in Regulation S-K. ${ }^{149}$

However, as I stated in my prior article, and as Fox ignores, there are express requirements for disclosure items in Regulation S-K that explicitly exempt firms from disclosing information that would "affect adversely the

${ }^{148}$ See, e.g., Russell Hardin, Collective Action $82-83$ (1982). The behavioral pattern is termed "hysteresis"; it is similar to the economic concept of risk aversion, with diminishing marginal utility of income, in which an individual values a one-dollar loss more highly than a one-dollar gain.

${ }^{149}$ Fox, supra note 3, at 1353. 
registrant's competitive position." ${ }^{150}$ Perhaps Fox's thesis is that if the SEC explicitly excludes such information for this specified item - new products and lines of business- then it must be assumed that the SEC intends that the disclosure of the other required items in the document will have such an impact. I draw the opposite conclusion, however. It seems far more plausible to assume that the SEC does not expect significant proprietary information to be contained in mandated disclosures concerning existing businesses compared to new businesses and that where it considered it likely that disclosure could compromise proprietary information, it made explicit that such information did not have to be disclosed.

The interpretation I advance of the SEC's view of proprietary information is supported by the SEC's current disclosure practice. In its most recent substantive addition to the disclosure requirements of Regulation S$\mathrm{K}$, the 1997 rules requiring the disclosure of the market risk of firms' positions in financial derivatives, the SEC adapted its disclosure requirements in response to commentators' concerns that specific detailed disclosures would reveal proprietary information. Namely, in response to the concern that "competitors, suppliers, and market traders potentially may be able to use the information to exploit the registrants' positions in the market," the SEC adopted four provisions that permit the aggregation of the disclosures over instruments and time-periods in order to ensure that the "disclosures do not reveal proprietary information."151

The explicit policy against the disclosure of proprietary information-the information relevant to the interfirm externalities that underlies Fox's rationale for a single regulator regime—suffuses the securities regime and not only the specific issuer mandates of Regulation S-K. In particular, money managers are not required to disclose their entire portfolio holdings so that they can protect the proprietary information of their investment strategies under the agency's established procedure for requesting confidential treatment of such information. ${ }^{152}$ In addition, under the more general disclosure standards of the antifraud provisions of the federal securities laws, both the agency and the courts permit firms to abstain from disclosing information that entails significant interfirm externalities, that is, items of substantial importance to competitors, such as a significant mineral lode discovery made by extracting firms ${ }^{153}$ or preliminary merger negotiations. ${ }^{154}$ If the courts and SEC interpreted their

\footnotetext{
${ }^{150}$ Regulation S-K, Item 101, 17 C.F.R. $\$ 229.101$ (c)(ii) (1999) (providing that an issuer is not required to disclose narrative information concerning new business lines and products "the disclosure of which would affect adversely the registrant's competitive position.").

${ }^{151}$ Securities and Exchange Comm'n, Disclosure of Accounting Policies for Derivative Financial Instruments and Derivative Commodity Instruments and Disclosure of Quantitative and Qualitative Information About Market Risk Inherent in Derivative Financial Instruments, Other Financial Instruments, and Derivative Commodity Instruments, 62 Fed. Reg. 6,044, 6,055 (Feb. 10, 1997).

${ }^{152}$ Instructions for Confidential Treatment Requests, Form 13F (Information Required of Institutional Investment Managers Pursuant to Section 13(f) of the Securities Exchange Act of 1934 and Rules Thereunder), 17 C.F.R. 249.325 (2001)

${ }^{153}$ See SEC v. Texas Gulf Sulphur Co., 401 F.2d 833 (2d Cir. 1968), cert. denied, 394 U.S. 976 (1969) (disclose
} 
mandate as does Fox, namely, to mitigate interfirm externalities, then firms would have to provide competitors with the timely disclosure of information useful in assessing rivals' profitability, and these exclusions would not be a fixture of the securities regime.

Indeed, if the purpose of the federal regime were to mitigate interfirm externalities—Fox's rationale—as opposed to the more conventionally understood rationale of investor protection given firms' underproduction of information, then the system of civil liability for disclosure violations under the securities laws would be dramatically different from its current form. Private rights of action would not be given to shareholders of issuers, but, rather, to the competitors who benefit from the positive externalities that are the ostensible object of mandatory disclosures. Because investor fraud concerns are not at stake according to the interfirm externalities rationale for a single securities regulator, the advocate of such a rationale logically must either consider such matters appropriately left to the states (and thus an area presumably appropriate for competitive regulation) or come up with a completely different rationale for much of the mandatory (non-competitive) federal regime. Fox has constructed an elaborate rationalization of the SEC's extensive disclosure regime based on Easterbrook and Fischel's theoretical justification, which has no connection to the agency's stated goals and agenda or its actual practices. Given that Fox's position is that interfirm externalities are the justification for federal securities regulation, to be intellectually consistent, he should be advocating a radical revamping of securities regulation and not advocating retention of the status quo for U.S. issuers.

But rather than attempt to divine the SEC's intentions from the presence or absence of exemptive provisos for disclosure of proprietary information and from a civil liability structure not in conformance with a regime directed at interfirm externalities, we can ascertain whether the agency's disclosure mandates are addressing such externalities by examining the actual disclosure practices of firms for the items in the Regulation S-K form that Fox identifies as supporting his thesis: "profits and sales of each significant individual line of business conducted by the issuer, future capital spending plans, research and development ("r\&d") spending, cost ratios, liquidity constraints, backlogs, inventories and sources of supply." ${ }^{155}$ Consider first r\&d disclosures, by examining the most recent Form 10-K entry for this item by Merck \& Co., one of the largest pharmaceutical companies, in a sector in which unlike the vast majority of firms, $\mathrm{r} \&$ d expense is significant enough to be included as a line item in financial statements:

or abstain rule for insider trading in context of discovery of major copper strike).

${ }^{154}$ See Basic, Inc. v. Levinson, 485 U.S. 224 (1988) (whether company must disclose preliminary merger negotiations depends on particular facts of case).

${ }^{155}$ Fox, supra note 3, at 1353 . The first item, line-of-business reporting, while theoretically of relevance to Fox's argument, is an even weaker example for his thesis in practice, given the numerous empirical studies that have studied this disclosure, and is discussed at infra notes 173-79 and accompanying text. 


\section{Research and Development}

The Company's business is characterized by the introduction of new products or new uses for existing products through a strong research and development program. Approximately 8,900 people are employed in the Company's research activities. Expenditures for the Company's research and development programs were $\$ 2,068.3$ million in 1999, $\$ 1,821.1$ million in 1998 and $\$ 1,683.7$ million in 1997 and will be approximately $\$ 2.4$ billion in 2000. The Company maintains its ongoing commitment to research over a broad range of therapeutic areas and clinical development in support of new products. Total expenditures for the period 1990 through 1999 exceeded $\$ 13.0$ billion with a compound annual growth rate of $11 \%$.

The Company maintains a number of long-term exploratory and fundamental research programs in biology and chemistry as well as research programs directed toward product development. Projects related to human and animal health are being carried on in various fields such as bacterial and viral infections, cardiovascular functions, cancer, diabetes, pain and inflammation, ulcer therapy, kidney function, mental health, the nervous system, ophthalmic research, prostate therapy, the respiratory system, bone diseases, endoparasitic and ectoparasitic diseases, companion animal diseases and production improvement.

In the development of human and animal health products, industry practice and government regulations in the United States and most foreign countries provide for the determination of effectiveness and safety of new chemical compounds through pre-clinical tests and controlled clinical evaluation. Before a new drug may be marketed in the United States, recorded data on the experience so gained are included in the New Drug Application, New Animal Drug Application or the biological Product License Application to the FDA for the required approval. The development of certain other products is also subject to government regulations covering safety and efficacy in the United States and many foreign countries. There can be no assurance that a compound that is the result of any particular program will obtain the regulatory approvals necessary for it to be marketed.

New product candidates resulting from this research and development program include an injectable antibiotic; an antifungal agent; an oral compound potentially useful for treatment of chemotherapy-induced emesis; an oral compound potentially useful for the treatment of depression and other neuropsychiatric diseases; a second COX-2 specific inhibitor potentially useful for the treatment of osteoarthritis, rheumatoid arthritis and pain; and certain new vaccines. ${ }^{156}$

Contrary to Fox's contention, this entry provides absolutely no details concerning the specific research undertaken, the stage of development, the likely success of the research, and so forth, for any particular drug, information of the sort asserted by Fox regarding SEC mandates that would be helpful to a competitor. The company's filing for the previous fiscal year, 1998, has a specific entry referring to the progress of a drug, Vioxx, produced by its $\mathrm{r} \& \mathrm{~d}$ program, through the FDA approval process, but the report provides no new information because there was a news report issued on the occurrence date of every reported event in the $10-\mathrm{K}^{157}$

${ }^{156}$ Merck \& Co., Inc., Form 10-K for fiscal year ended Dec. 31, 1999 (filing date with SEC Mar. 22, 2000).

${ }^{157}$ Merck \& Co. Inc., Form 10-K for fiscal year ended Dec. 31, 1998 (filing date with SEC Mar. 24, 1999). ("New product candidates resulting from this research and development program include Vioxx, a new antiinflammatory product for the treatment of osteoarthritis and relief of pain, for which the company filed an NDA with the FDA on November 23, 1998. On January 11, 1999, the FDA assigned a six-month priority review to the company's 
The same point can be made regarding future capital spending plans. Consider Merck's 1999 10-K entry under the capital expenditures item identified by Fox as providing useful information to competitors:

\section{Capital Expenditures}

Capital expenditures were \$2.6 billion in 1999 and \$2.0 billion in 1998. Expenditures in the United States were \$2.0 billion in 1999 and \$1.4 billion in 1998. Expenditures during 1999 included $\$ 1.0$ billion for production facilities, $\$ 664.5$ million for research and development facilities, $\$ 101.7$ million for environmental projects, and \$784.4 million for administrative, safety and general site projects. Capital expenditures approved but not yet spent at December 31, 1999 were $\$ 2.5$ billion. Capital expenditures for 2000 are estimated to be $\$ 2.8$ billion.

Again, this entry is of little value to a competitor for assessing the profitability of Merck or industry conditions.

Two final examples will, hopefully, not belabor the point too much. Fox's list of disclosures providing valuable data to competitors includes the item "liquidity constraints." Firms do not typically report much information under this item unless they are in financial difficulty. Merck's entry under "liquidity" simply states that it has enough cash to cover its capital expenditures and notes its triple-A debt rating. Surely, the only time in which such an entry could be valuable for a competitor would be when liquidity matters, that is, when a firm is in economic distress. Consider, therefore, the entry of Paging Network (PageNet), a wireless communications company, which was the largest paging carrier in the United States and had a significant entry discussing such a constraint in its 1999 Form 10-K:

PageNet's deteriorating financial results and defaults under its debt agreements have resulted in significant liquidity constraints. The report of PageNet's independent auditors expresses substantial doubt about its ability to continue as a going concern. See discussion under "Liquidity and Capital Resources."

\section{LIQUIDITY AND CAPITAL RESOURCES}

\footnotetext{
NDA for Vioxx. In February 1999, the company received confirmation that the FDA's Arthritis Advisory Committee meeting for Vioxx had been scheduled for April 20, 1999.") Three examples of news reports and comp any press releases of these facts, which were obviously stale information by the time of the mandated 10-K disclosure are: Robert Steyer, Monsanto Drug Gets FDA Hearing Tuesday, St. Louis Post-Dispatch, Nov. 29, 1998, at E1 (reporting that Merck submitted its application for Vioxx a few days earlier for FDA review, putting it three months behind Monsanto's petition for a competing drug, Celebrex, which is to commence being reviewed by an FDA advisory committee in two days); FDA Grants Priority Review for Vioxx(TM), Merck's Investigational Medicine for Osteoarthritis and Pain, PR Newswire, Jan. 11, 1999; Merck \& Co., Inc., 255 Chemical Market Rep., Mar. 1, 1999, at 19 (announcing that Merck reports an FDA advisory committee will meet on April 20 to consider approval status for Vioxx). It should further be noted that while newspaper reports referred to the earlier start in the approval process for a competing drug to Vioxx, Merck's 10-K made no reference to that drug. This is further evidence at odds with Fox's claim of the SEC's key role in the release of significant information relating to interfirm externalities.
} 
General

PageNet's deteriorating financial results and liquidity have caused PageNet to be in default of the covenants of all of its domestic debt agreements. On February 2, 2000, PageNet failed to make the semi-annual interest payment on its $8.875 \%$ senior subordinated notes due $2006(8.875 \%$ Notes), and its $10.125 \%$ senior subordinated notes due 2007 (10.125\% Notes). As of March 2, 2000 , the non-payment of interest constituted a default under the indentures of the $8.875 \%$ Notes and the 10.125\% Notes. As of April 17, 2000, PageNet failed to make the semi-annual interest payment on its $10 \%$ senior subordinated notes due 2008 (10\% Notes), and does not expect to make additional cash interest payments on any of its Notes. As a result of this default, PageNet's bondholders could demand at any time that PageNet immediately pay $\$ 1.2$ billion of its bonds in full. Should this happen, PageNet would immediately file for protection under Chapter 11 of the United States Bankruptcy Code (Chapter 11).

PageNet is also in default of several of the financial and other covenants of its Credit Agreement. As a result of these defaults, the lenders under the Credit Agreement could demand at any time that PageNet immediately pay the $\$ 745$ million outstanding under the Credit Agreement in full. Should this happen, PageNet would immediately file for protection under Chapter 11.

PageNet is prohibited from additional borrowings and has classified all of its outstanding indebtedness under the Credit Agreement and the Notes as a current liability as of December 31, 1999. As of May 1, 2000, PageNet had approximately $\$ 55$ million in cash. PageNet believes that this cash, plus the cash expected to be generated from operations, is sufficient to meet its obligations, except for the cash interest payments due under the Notes, into the third quarter of 2000. However, if PageNet's financial results continue to deteriorate, PageNet may not have enough cash to meet such obligations through the third quarter of 2000. PageNet is considering alternatives to ensure that it has sufficient liquidity through the completion of the Merger. However, there can be no assurance that PageNet's efforts to obtain additional liquidity will be timely or successful or that the Merger will be completed. As a result, PageNet may have to reduce the level of its operations and/or file for protection under Chapter 11 to complete the Merger and/or restructure its obligations. PageNet is negotiating a debtor-in-possession loan facility with its lenders to be made available in the event it commences a Chapter 11 case. Filing for bankruptcy would have a material impact on PageNet's results of operations and financial position.

PageNet's deteriorating financial condition and lack of additional liquidity indicate that PageNet may not be able to continue as a going concern for a reasonable period of time. PageNet's ability to continue as a going concern is dependent upon several factors, including, but not limited to, the continued non-demand for immediate payment of outstanding indebtedness by the holders of the Notes and the lenders under the Credit Agreement and PageNet's ability to (i) generate sufficient cash flows to meet its obligations, other than the cash interest payments due under the Notes, on a timely basis, (ii) obtain additional or restructured financing, including potential debtor-in-possession borrowings if PageNet is required to file for protection under Chapter 11, (iii) continue to obtain uninterrupted supplies and services from its vendors, and (iv) reduce capital expenditures and operating expenses. PageNet is proceeding with these initiatives as well as also proceeding with its plan to complete the Merger described above. ${ }^{158}$

${ }^{158}$ Paging Network Inc., Form 10-K for fiscal year ended Dec. 31, 1999 (filing date with SEC May 4, 2000). This was the first report identified in a search for a filing with the words "liquidity" and "constraint" of all 10-K filings 
This firm has provided a detailed description of its financial problems. But it does not reveal to a competitor either marginal cost or other key information that could provide information on how a rival would fare in the marketplace, the disclosures Fox considers key for the externalities rationale. More important, this entry does not provide any new information of value to competitors regarding PageNet's liquidity. PageNet's financial difficulties were well-known prior to the release of the annual report: its debt had been downgraded in the previous quarter, and it had, in fact, entered into a merger agreement with its major competitor to stave off bankruptcy, which was also reported in the $10-\mathrm{K}$ filing. ${ }^{159}$ Competitors, particularly its merger partner, did not learn of PageNet's 's liquidity problems, nor acquire crucial data regarding its profitability, from the information available in the SEC's mandated disclosure requirements.

Competitors, in fact, obtain a better sense of industry sector costs and profit margins from their own cost accounting than from information provided in another firm's SEC filings. Fox's thesis would seem more relevant for noncompetitive industries where consumers would benefit from new entrants who are deterred from entry due to ignorance of sector profitability. Few U.S. industries fall into this category, however. To return to the PageNet example, undoubtedly, the relevant players in the wireless communications industry were aware of the company's financial difficulties prior to its SEC filings. As Pagenet's customers found the company increasingly unable to provide adequate service, its competitors would have readily heard the buzz in the industry of its deteriorating position, and this would have percolated into the financial press.

There is nothing to suggest that the boilerplate or after-the-fact disclosures in PageNet's SEC filings could be combined by a rival with proprietary information to glean insight into the profitability of the industry or product line, and Fox does not provide concrete examples of such use. In support of his thesis, Fox states that while he was in practice, his clients did not want to disclose items that were not clearly required and gave as "their most frequent reason ... fear that the information will be used by their competitors." 160 He points to this as evidence that the SEC requires such information disclosure. I do not wish to minimize Fox's experience in practice. However, more probative evidence on the content of the SEC's mandated disclosures than his clients' unwillingness to disclose information when the disclosure requirement was not "absolutely clear" would be if they had informed him that they had spent time pouring over competitors' SEC filings to learn about their competitive

for fiscal year 1999, LEXIS, COMPNY Library, 10-K File.

${ }^{159}$ See, e.g., Antony Bruno, Moody's Lowers Pagenet's Debt Rating, Radio Comm. Rep., Oct. 11, 1999, at 3; Antony Bruno, Tie-up Aids Troubled Industry, Radio Comm. Rep., Nov. 15, 1999, at 1 (reporting merger of Arch Communications Group, the second-largest paging carrier, with Paging Network, its rival and the number-one carrier, and noting analysts saw merger as only way for Pagenet to avoid bankruptcy, a growing concern all year).

${ }^{160}$ Fox, supra note 3, at 1354 n.42. 
positions in the industry and did in fact obtain such information. I doubt whether he heard about such activity while in practice. It is improbable that people engage in such activity, because there is little information of important proprietary (competitive) value to glean from SEC documents.

As a final example, consider the following entries under the "backlog" item on Fox's list. ${ }^{161}$

(1) Capital Pacific Holdings, Inc., a regional builder and developer:

\section{BACKLOG AND INVENTORY}

The Company typically pre-sells homes prior to and during construction through home purchase contracts requiring earnest money deposits or through reservation documents requiring reservation deposits. Generally, reservation deposits are refundable, but home purchase contracts are not cancelable unless the customer is unable to sell their existing home, qualify for financing or under certain other circumstances. A home sale is placed in backlog status upon execution of such a contract or reservation and receipt of an earnest money deposit or reservation deposit and is removed when such contracts or reservations are canceled as described above or the home purchase escrow is closed.

The following table shows backlog in units and dollars at the end of each of the last three fiscal years for each of the Company's residential operations, including unconsolidated joint ventures:

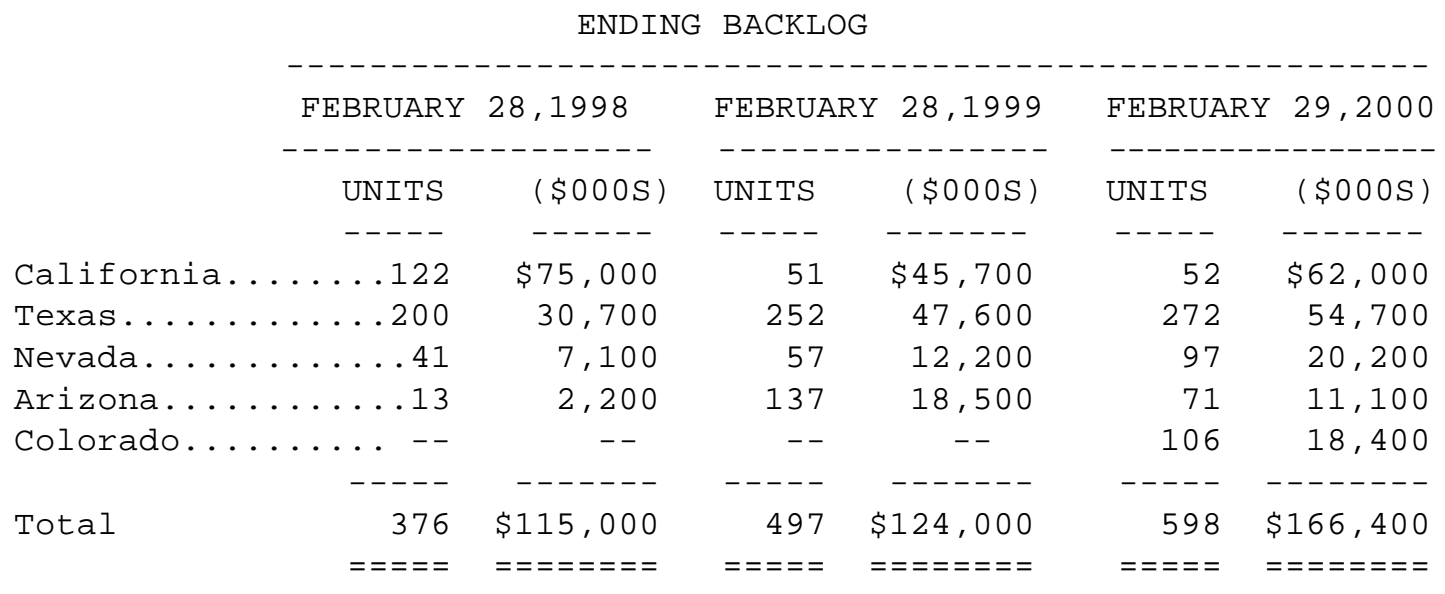

The following table shows net new orders (sales made less cancellations and credit rejections), homes closed and ending backlog relating to sales of the Company's homes and homes under contract or reservation for each quarter since the beginning of fiscal year 1999, including

${ }^{161}$ The following firms are the first five firms that were found in a LEXIS search, undertaken June 3, 2000, of 10-Ks filed in 2000 that included the word "backlog." Because, in contrast to the other items, there was so little meaningful content and so much variety in the entries under this heading, I provide the report of five firms rather than one firm. 
unconsolidated joint ventures. The Company's backlog at any given time is a good indicator of the number of units that will be closed in the four to six months following such date:

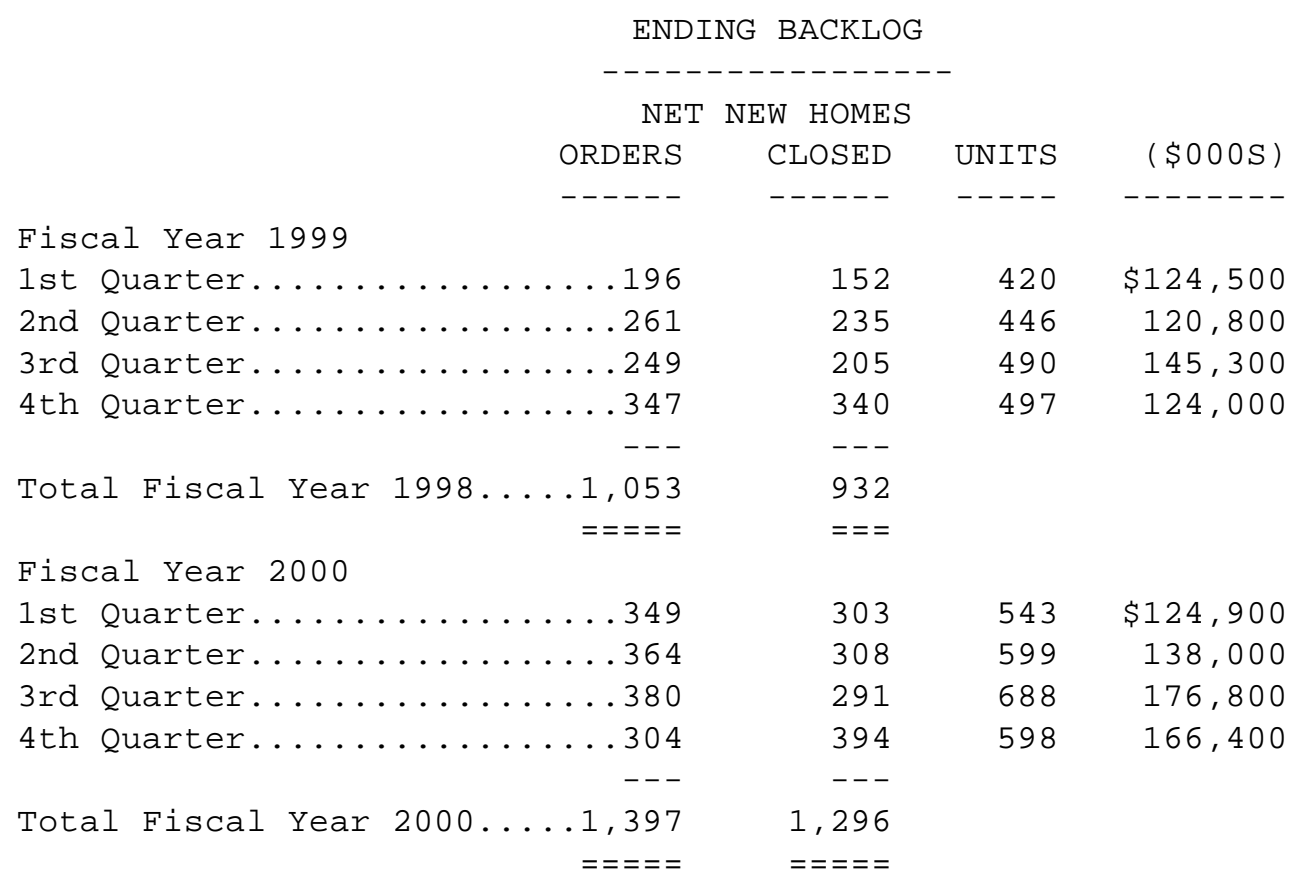

(2) Littlefield, Adams \& Company, a designer and distributor of young men's and boys' active wear products:

\section{INVENTORY, BACKLOG AND PRODUCTION}

The Company maintained an inventory in 1999 substantially in excess of anticipated demands. The total value of such inventory as of December 31, 1998, was $\$ 3,157,000$. As of December 31,1999 , it had $\$ 377,000$ in inventory, after a program of inventory sales started in September 1999.

Approximately $77 \%$ of the goods produced in 1999 were through the services of contract screen printers, with $76 \%$ through one outside contractor.

Generally, Littlefield requires payment for goods within 30 to 60 days after delivery; however, exceptions are made on a case by case basis depending on circumstances such as sizes of orders, anticipated future business and past credit experience. As of December 31, 1999, the Company had trade receivables of $\$ 830,000$, with an average aging period, from date of shipment, of 36 days.

(3) Hirsch International Corp., a supplier of embroidery machinery: 


\section{Backlog and Inventory}

The ability of the Company to fill orders quickly is an important part of its customer service strategy. The embroidery machines held in inventory by the Company are generally shipped within a week from the date the customer's orders are received, and as a result, backlog is not meaningful as an indicator of future sales.

(4) Republic Technologies International Holdings, producer of specialty steel products:

\section{BACKLOG}

The company calculates backlog as those orders received but not yet shipped. Its combined backlog as of December 31, 1999 and 1998, was \$297 million and \$306 million on a proforma basis, respectively. Orders are generally filled within 3 to 14 weeks of the order depending on the product, customer needs and other production requirements. Customer orders are generally cancelable without penalty prior to finish size rolling, and depend on customers' changing production schedules. Accordingly, the Company does not believe that the amount of backlog orders is a reliable indication of future sales.

(5) SMLX Technologies, Inc., a developer of technological solutions for the medical, dental and other industries:

The Company anticipates that it will not be required to maintain significant inventory levels of products until the Company's products are deemed acceptable for sale. The Company does not currently have any material backlog. Until the Company is able to market its products on a broad basis, it does not anticipate that its backlog or inventory level will be material. At that time, the Company intends to cause these products to be manufactured for it shortly before they are required for shipment. The Company does not foresee that an extensive period of time will be required from the time of its manufacturing order to the time of final delivery of its products.

These last illustrations should make the point crystal clear regarding the distance between Fox's claim concerning the content of SEC filings and reality. Of the five firms, the disclosures of four are uninformative if the disclosure's purpose is to improve a rival's competitive position. Only one firm, Capital Pacific Holdings, provided much specific detail regarding the number of backlogged units, but the backlog in question involved a standard accounting practice for housing sales; another, Littlefield, Adams provided the average age of its trade receivables. Perhaps a competitor could conceivably gain some information about the firms' competitive position from the disclosures, but this is hardly the significant proprietary data that inform Fox's characterization of the SEC's disclosure policy. The thoroughly generic disclosures in the mandated items that Fox himself asserts are likely to generate value to competitors indicate that any real benefits to competitors from such disclosure mandates are either accidental or trivial.

When firm-specific information is provided beyond the standard boilerplate disclosures, the information is of such significance to the firm's own investors that it is in practice revealed prior to the SEC's mandated filing, despite its potential value to competitors: it is independently revealed in press releases or reported by financial 
reporters and analysts. ${ }^{162}$ If SEC filings provide any meaningful competitive information about rivals in the context of the information-intensive activities of financial analysts, arbitragers, and other market professionals, as well as competitors' own information about their business, it is surely not by design.

Perhaps Fox would respond to the criticism that important firm-specific information with spillover effects released in advance of SEC filings would not be reported by firms or uncovered by independent sources if the SEC did not mandate its eventual disclosure. But such a contention would not be convincing. Announcements of capital and r\&d expenditures, for example, have significantly positive stock price effects. ${ }^{163}$ Hence managers have a strong incentive to reveal information about such activities because they benefit from their revelation and do not need a government mandate to prod disclosure. Financial difficulties, on the other hand, as revealed by liquidity constraint disclosures, are not matters that management affirmatively benefits from revealing, unless the disclosure would indicate that problems are less severe than investors have anticipated, as silence is considered bad news. Quite apart from the incentive of managers to reveal information to avoid the adverse inferences drawn by investors from silence, market professionals have powerful incentives to uncover adverse information about firms. In addition, financial difficulties affect third-party relations (dealings with customers, suppliers, and creditors), and hence the information finds its way into the business press. Prior to running up against explicit liquidity constraints, for instance, firms' troubles are invariably well known, and they experience downgrades by bond-rating agencies, which are publicized events. For instance, months before PageNet's SEC filings indicated any significant financial difficulties, the press reported that Moody's was considering downgrading the company's debt. ${ }^{164}$

${ }^{162} \mathrm{~A}$ further illustration of the potency of the incentives for revealing such information involves potential takeovers: prior to the announcement of a bid (which will be disclosed under SEC rules), the target's shares advance in price and examinations of the source of the runup suggest that it is due not to insider trading but to information generated by the rumor mill of Wall Street, a "legitimate market for information." Gregg A. Jarrell \& Annette B.

Poulsen, Stock Trading Before the Announcement of Tender Offers: Insider Trading or Market Anticipation?, 5 J.L. Econ. \& Org. 225, 244 (1989). See also id. at 227-29.

${ }^{163}$ E.g., Su Han Chan et al., Corporate Research and Development Expenditures and Share Value, 26 J. Fin. Econ. 255 (1990); John J. McConnell \& Chris J. Muscarella, Capital Expenditure Decisions and Market Value of the Firm, 14 J. Fin. Econ. 399 (1985); SEC Office of Chief Economist, Institutional Ownership, Tender Offers and Long Term Investments (1985).

${ }^{164}$ Pagenet Debt under Review, Dallas Morning News, Mar. 3, 1999, at 3D. I searched all the SEC filings for Paging Network available on line through 1998. The first filing to indicate a liquidity problem was the third-quarter 1999 10-Q, which was filed in November 1999, in which the company noted that it was precluded from further borrowing under the terms of its notes and that there was no assurance that it would be able to obtain additional liquidity, or that its proposed merger would be consummated, and hence that it would avoid bankruptcy. The earliest filing to raise any possible concern was the first quarter 10-Q, filed in May 1999, thus several months after the news report regarding Moody's consideration of a downgrade, in which management stated that the company was in compliance with its credit agreement covenants and that "while no assurances could be given, the Company believes that ... it will remain in compliance." Paging Network, Inc., Form 10-Q (filed with SEC on May 17, 1999), available at 
Besides his specific examples of SEC mandates in Form S-K that evince an objective to disclose interfirm externalities, Fox contends that "almost all potential corporate disclosures" have the effect of a real externality, that is, can affect other firms' cash flows. ${ }^{165}$ This is a fallacy. Most information in fact does not have such an effect. A good example of this fallacy is the very item that Fox cites as evidence of the need for the SEC because of inadequate voluntary disclosure prior to 1934 , namely, depreciation. ${ }^{166}$ Depreciation has no bearing on other firms' cash flows: indeed, it has no bearing on a firm's own cash flows because accountants' measure of book depreciation has no connection to an asset's economic depreciation, except by chance, or any maintenance expenditures by the firm and, hence, no relation to the asset's value (its replacement cost). ${ }^{167}$

Another example from 1934 Fox cites in order to bolster his interfirm externality case is the disclosure of sales, the one major item that the SEC mandated upon its creation that the New York Stock Exchange had not previously mandated of its listed firms. ${ }^{168}$ To Fox, this demonstrates that the SEC's disclosure policy includes valuable interfirm externalities. He is mistaken. The SEC mandated disclosure of gross or net sales and cost of goods sold; marginal cost data, information that could enable competitors to ascertain their rivals' profitability, are not revealed in these disclosures, which instead provide extremely general information regarding a firm's profitability. The sales figures whose disclosure was mandated are not more useful to competitors than to the firm's investors, as they should be under Fox's rationale for disclosure. ${ }^{169}$ Accordingly, this is not a particularly robust instance of mandatory disclosure directed at remediating interfirm externalities.

There is still another reason to be skeptical of Fox's claim that the mandated disclosure of sales by the newly-created SEC revealed important interfirm externalities. Fox's source, a 1939 law review article by two SEC staff attorneys states, consistent with his thesis, that firms did not want to disclose sales information because these figures would give competitors an advantage, and that originally the agency accepted firms' proprietary concerns and granted exemptions from disclosure. ${ }^{170}$ However, the article goes on to state that the SEC changed this policy when an investigation revealed that the "disclosure had little effect upon buying policy" because

LEXIS, COMPNY Library, Filings File. The language in the second quarter 10-Q, filed in August 1999, was identical to that of the first quarter report, $i d$.

${ }^{165}$ Fox, supra note 3, at 1353.

${ }^{166} I d$. at 1378 .

${ }^{167}$ See, e.g., Rick Antle \& Stanley Garstka, Financial Accounting (forthcoming 2002) (manuscript at 15-23) (Chapter 11: Long-Term Assets); William H. Beaver \& Roland E. Dukes, Interperiod Tax Allocation and Depreciation Methods: Some Empirical Results, 48 Acct. Rev. 549 (1973) (estimations providing evidence that accounting depreciation methods were not consistent with underlying cash flows of assets).

${ }^{168}$ Fox, supra note 3, at 1353 n.33.

${ }^{169}$ For a discussion of the benefits of these disclosures to investors, see Maurice C. Kaplan \& Daniel M. Reaugh, Accounting, Reports to Stockholders, and the SEC, 48 Yale L.J. 935, 948 (1939).

${ }^{170}$ Id. at $946-47$. 
“competitors and customers had already obtained the 'confidential' information' (emphasis added)." ${ }^{171}$ This fact demolishes Fox's claim regarding the sales data. For if the information was available to competitors without its being released in firms' financial statements, then the SEC mandated-disclosure could hardly be an instance of remediation of interfirm externalities that are neither voluntarily produced nor discoverable by competitors. Moreover, the discussion in the article is in direct opposition to Fox's hypothesized regulatory rationale: it indicates that when the agency believed a disclosure mandate would adversely affect a firm's competitive position, it did not require the specific disclosure.

The final item that Fox cites as an instance of the optimality of the SEC's mandatory disclosure compared to voluntary disclosure because it concerns interfirm externalities is the line of business or segment reporting standards. These standards were adopted by the SEC in the late 1960s and have been intensively studied by accountants and economists. While, as I noted in my prior article, ${ }^{172}$ information regarding the profitability of a conglomerate by line of business could provide information of value to competitors and produce a real cash-flow effect, the implementation of this reporting requirement under the SEC rules has rendered it improbable that it would ever have such an effect. As Edmund Kitch has cogently indicated, under the segment reporting rules, a firm is accorded broad discretion to allocate costs and group activities, and consequently, the rules cannot be expected to lead to any significant disclosure of private information that would benefit competitors. ${ }^{173}$ Kitch explains this perhaps paradoxical result by the further contention that it is virtually impossible in practice to implement a disclosure regime that includes proprietary information of the sort of concern to Fox: either firms will not meaningfully disclose the information or else they will delist to avoid disclosure. ${ }^{174}$ Kitch's thesis sheds light on the SEC's implementation of its segment-reporting requirement: recognizing the quandary, the agency naturally prefers non-meaningful disclosures to delistings.

The best available data are in accord with Kitch's analysis, rather than Fox's position. Empirical studies of

${ }^{171}$ Id. at 947.

${ }^{172}$ Romano, supra note 2, at 2380-81.

${ }^{173}$ Edmund W. Kitch, The Theory and Practice of Securities Disclosure, 61 Brook. L. Rev. 763, 858 (1995). Economists and accountants have modeled the segment disclosure choice as a strategic game in which the disclosers use the information to disadvantage competitors. A study testing such models found, consistent with Kitch's hypothesis, that the choice to report a segment separately depends on the competitiveness of the industry and the variation in the firm's earnings persistence (profitability) in that sector, such that firms are less likely to disclose segments separately when they are consistently earning abnormal profits. Rachel M. Hayes \& Russell Lundholm, Segment Reporting to the Capital Market in the Presence of a Competitor, 34 J. Acct. Res. 261, 264 (1996) (one model of the strategic disclosure choice and discussion of findings of unpublished empirical study testing the strategic choice models). The recent accounting standard change regarding segment reporting, which was directed at management's discretion, is discussed at infra note 445.

${ }^{174}$ Kitch, supra note 173 , at 874. 
segment reporting uniformly show that it has had no price impact on firms. ${ }^{175}$ Fox states that this is to be expected since some segment information should affect firms positively and others negatively. ${ }^{176}$ However, this rationalization is at odds with his critique of Dye's model, as well as with the basis for his social welfare analysis of disclosure policy, in which he asserts that the externality is necessarily in one direction, positive (that is, the cash flow effect will be negative to the discloser and positive to its competitors). Fox cannot have it both ways and be theoretically consistent. Under his hypothesis, there should be a negative price effect on a disclosing firm because it is releasing proprietary information that will have an adverse impact on its value (otherwise, it would have voluntarily disclosed the information). If Fox meant instead to contend that the lack of a price effect is due to disclosing firms' benefiting from rivals' simultaneous disclosures regarding their lines of business, then again, his rationalization of the data is inconsistent with his theory of regulation: because under his analysis of interfirm externalities, the gains of competitors are, by definition, greater than the losses of disclosing firms, then there should still be a significant price effect for the portfolio of disclosing firms, albeit a positive, not a negative, one.

Fox further contends that the fact that some of the studies of segment reporting show a reduction in the variance of returns after the segment reporting requirement was adopted indicates that such disclosures are an example of the information that he defines as interfirm externalities. ${ }^{177}$ This contention is incorrect. If a piece of information entails an externality such that it increases competitors' value at the expense of the disclosing firm, then there must be a price effect, not a variance effect, from the disclosure of such information. That is the definition of an interfirm externality—it affects other firms' cash flows. Thus, in the formal models discussed earlier, the item of information subject to potential disclosure regulation, which was the precision (inverse of the variance) of a firm's returns, has an impact on the returns of other firms, not on the variances of the returns. Accuracy of pricing is not evidence of a cash-flow impact. Hence a reduction in the variance of returns on the introduction of segment reporting, a change on which there is not even consensus in the literature as to its oc currence, does not indicate that the information released in segment reporting involves interfirm externalities (affected the value of other firms' cash flows).

To the extent that there was a reduction in the variance of prices from the segment reporting disclosures,

${ }^{175}$ See Bipin B. Ajinkya, An Empirical Evaluation of Line-of-Business Reporting, 18 J. Acct. Res. 343, 35759 (1980) (no effect on returns, increased consensus in probability assessments); Daniel W. Collins \& Richard R. Simonds, SEC Line-of-Business Disclosure and Market Risk Adjustments, 17 J. Acct. Res. 352, 372-73, 378-80 (1979) (change in market risk); Bertrand Horwitz \& Richard Kolodny, Line of Business Reporting and Security Prices: An Analysis of an SEC Disclosure Rule, 8 Bell J. Econ. 234, 239, 241-42, 246 (1977) (no effect on market risk or on returns); see generally Rosanne M. Mohr, The Segmental Reporting Issue: A Review of Empirical Research, 2 J. Acct. Literature 39, 45-52, 56-62 (1983) (literature review summarizing general results of no effect on returns, some improvements in analyst forecasts, increased consensus, evidence mixed concerning whether market risk shifted).

${ }^{176}$ Fox, supra note 3, at 1355.

${ }^{177} \mathrm{Id}$. 
this suggests that the requirement resulted in greater standardization in reporting, which increases comparability across firms. While this effect may well benefit investors, ${ }^{178}$ it is not a benefit that entails an interfirm externality of the sort that Fox uses to justify the single regulator regime; that is, it is not a benefit to competitors (standardization of disclosure does not enable competitors to determine more accurately the profitability of their rivals and thereby to adopt more efficient business strategies; indeed, it may even obscure special idiosyncrasies of particular firms as it forces all firms into compliance with a specific format). Moreover, even were standardization to benefit the competitors for whom Fox posits the mandatory disclosure regime exists, Fox provides no evidence that a single government agency is necessary to obtain standardized disclosure. Standardization occurs in numerous contexts where there is no single government regulator; the substantial uniformity of corporate law rules is one of the more prominent examples. ${ }^{179}$ In any event, the benefit of standardization is not Fox's justification for mandatory disclosure under a single regulator, because it has nothing to do with remediating interfirm externalities.

The data on the impact of the SEC's mandated segment reporting disclosures are important indicia that even the context that would appear to fit best with Fox's interfirm externalities rationale for a single securities regulator fails to do so. Contemporary disclosure practices do not support the interfirm externalities rationale, because firms simply do not disclose this type of information under existing SEC mandates. This is not because firms are deliberately ignoring SEC mandates; it is because the SEC does not require them to do so. When a theory of regulation is not theoretically well-grounded and cannot practicably be implemented, as is true of the interfirm externalities rationale for a single securities regulator, then the position ought to be discarded rather than promoted as the basis for public policy and, in particular, for justifying the status quo in securities regulation.

\section{Evaluating the Empirical Data on the Efficacy of the Federal Securities Regime}

In developing the thesis for opening securities regulation up to competition, I sought to make the case empirically - particularly given the ambiguity in economic models regarding the efficacy of government disclosure mandates - by drawing on the finance literature studying the impact of the federal securities laws and the empirical literature on competition for corporate charters in the United States. The finance literature on the federal

${ }^{178}$ A decline in the variance of stock returns is not necessarily an improvement in investor welfare. Namely, in an efficient market, stock prices change frequently as information is released, so the more information that is produced by firms, the higher we might expect the volatility of returns to be. From this perspective, a decline in volatility after a rule change may indicate that in reaction to the rule, there was a reduction in the information produced by firms, with a concomitant reduction in price adjustment. A rule with such an impact does not benefit investors.

${ }^{179}$ For a more detailed discussion of why standardization does not require a single regulator, see infra notes 219-21 and accompanying text. 
securities laws suggests that the regime has not been effective. But because this literature cannot demonstrate the effectiveness of the alternative to the SEC regime, regulatory competition, the literature on state competition for charters is useful to consult, as it provides an existing legal context from which we can project what, in all likelihood, will occur under competition among securities regulators. ${ }^{180}$

Fox takes issue with my reading of the finance literature assessing the federal securities laws. ${ }^{181}$ In this Part, I show why Fox's critique is mistaken.

\section{Benston's Study of the Disclosure Mandated by the 1934 Act}

As discussed in my prior article, the groundbreaking study on the impact of the 1934 Act was conducted by George Benston several decades ago. ${ }^{182}$ Benston investigated the impact of the Act on firms' returns by comparing pre- and post-Act returns of firms affected by the Act—those not disclosing sales data prior to the Act—with those that were not affected—-those already disclosing sales data. Benston examined sales data as the distinguishing feature, because sales, along with cost of goods sold, was the only item mandated by the SEC that all NYSE-listed firms had not disclosed before the Act. ${ }^{183}$ Benston found that the legislation had no significant price effect. ${ }^{184}$ Because new information is impounded into stock prices in capital markets upon its disclosure, we can infer from the absence of a price effect that the Act's mandated disclosure of sales data did not provide meaningful information to investors.

Benston's result is at odds with a characterization of the disclosure regulation mandated by the SEC under the 1934 Act as an improvement for investor welfare over the preexisting voluntary disclosure scheme. Fox maintains that Benston's test is not the correct test of the welfare effects of the Act. This claim has two parts. Fox first turns Benston's study on its head by asserting that to improve investor welfare, the mandated disclosure

${ }^{180}$ The state competition literature is discussed in the succeeding part, which illustrates that despite some commentators' claims to the contrary, e.g., Lucian Bebchuk \& Allen Ferrell, Federalism and Corporate Law: The Race to Protect Managers from Takeovers, 99 Colum. L. Rev. 1168 (1999), the experience of charter competition has, on the whole, benefited shareholders, is better than the alternative, and is quite relevant for an analysis of securities regulation. Fox does not offer any evidence to dispute my characterization of the state competition literature, but cites other commentators who disagree with it and asserts that the interfirm externalities rationale for securities regulation renders the corporate law experience irrelevant. Fox, supra note 3, at 1392-93. Because disclosure of interfirm externalities does not provide a compelling rationale for a single securities regulator, see supra Part III.B., the experience of state competition for corporate charters is instructive for predicting the effect of regulatory competition on securities law.

${ }^{181}$ Fox, supra note 3, at 1370-91.

${ }^{182}$ George J. Benston, Required Disclosure and the Stock Market: An Evaluation of the Securities Exchange Act of 1934, 63 Am. Econ. Rev. 132 (1973).

${ }^{183}$ Id. at 133; see also George J. Benston, The Value of the SEC's Accounting Disclosure Requirements, 44 Acct. Rev. 515, 519 (1969) (table indicating items disclosed by all NYSE firms from 1926-1934).

${ }^{184}$ Benston, supra note 182, at 144-45. See also George J. Benston, An Appraisal of the Costs and Benefits of 
under the Act should have an effect on variance, not on price. He then raises a series of objections to the specifics of Benston's test of a stock price effect. For ease of exposition, I discuss Fox's arguments in reverse order.

a. Why Benston's test for a stock price effect is the correct measure of the effect of the 1934 Act on investor welfare. In critiquing Benston's test of a stock price effect of the 1934 Act, Fox raises several objections. He first objects to Benston's examination of a "single disclosure item." 185 This objection is inappropriate. The "single" item in question, sales, is the only significant financial datum whose disclosure the SEC mandated that the NYSE did not require of listed firms before the Act, as well as the only item of the mandated items that many NYSE firms did not voluntarily disclose before the Act. ${ }^{186}$ Consequently, this is the best piece of information with which to test whether the Act had an effect, for it provides us with a natural experiment: we can contrast the impact of the Act on firms for which it imposed a disclosure requirement compared to those for which it did not.

Fox next challenges Benston's hypothesis that the Act should have a differential effect on prior nondisclosers compared to prior disclosers of sales data. He contends instead that the correct hypothesis is that there should be no effect; that is, the price impact should not differ between pre-Act disclosing and non-disclosing firms. Fox's prediction is founded on the view that the quality of sales information disclosed before the SEC was established pursuant to the 1934 Act was lower than that of the sales information disclosed after the agency's creation, and hence, all firms, regardless of their pre-Act disclosure status, benefited equally from the legislation. ${ }^{187}$ This is an odd hypothesis because it implies that the SEC's mandatory sales disclosure imposed a new disclosure requirement on firms that were already disclosing sales and not simply on firms that had not previously done so. Under Fox's hypothesis, investors would have reevaluated the price of firms that, after the Act, disclosed sales information for the first time the same as they evaluated the price of firms that had already been disclosing sales information prior to the Act. The assertion that the Act's impact would have been no different for disclosers than for non-disclosers is, however, implausible, because if the SEC were remedying a market failure and sales information were important to investors, then they should have reassessed the value of a firm that went from no disclosure to disclosure of sales information after the Act differently from their assessment of the value of a firm that always had disclosed some sales information. Fox does not provide any explanation for why moving from zero to high-quality disclosure would have precisely the same price effect as

Government-Required Disclosure: SEC and FTC Requirements, 41 Law \& Contemp. Probs. 30, $51-51$ (1977).

${ }^{185}$ Fox, supra note 3, at 1373 n.91.

${ }^{186}$ Benston, supra note 182, at 133,142. The SEC apparently copied much of the NYSE disclosure requirements. See Paul G. Mahoney, The Exchange as Regulator, 83 Va. L. Rev. 1453, 1466 (1997).

${ }^{187}$ Fox, supra note 3, at 1373 n.91. 
moving from low- to high-quality disclosure, but such an explanation is necessary given Benston's data (no differential price effect). Moreover, there is no evidence that the quality of pre-Act disclosers' sales figures improved after the Act, data that would also be necessary for Fox's hypothesis to be correct. ${ }^{188}$

The data concerning the disclosure of cost of goods sold cast further doubt on Fox's contention that Benston's results are questionable because of an absolute improvement in disclosure quality after the Act. As previously noted, cost of goods sold, like sales, was an item required by the SEC that was not required by the NYSE. Although there was an increase in the number of firms disclosing cost of goods sold in their income statements after the Act (a rise from 33 to 47 firms), the increase occurred primarily in the disclosure category that is described as the lowest quality, the one that did not include depreciation, selling, and general and administrative expenses in the calculation of cost of goods sold (a rise from 8 to 17 firms). In fact, for the disclosure category described as the highest quality, which included all of these items in the computation, there was a decline (a drop from 9 to 5 firms). ${ }^{189}$ Thus, cost of goods sold is not an item for which Fox's claim of an increase in the quality of disclosure by all firms post-Act holds. Yet Benston's results are identical-there was no price effect—when he uses cost of goods sold instead of sales in his analysis of the 1934 Act's impact. ${ }^{190}$ This suggests that the more plausible explanation of the data is Benston's, not Fox's: there was no price effect because mandated disclosure did not improve upon the voluntary disclosure provided prior to the Act.

There are other reasons to question the claim of the inadequacy of the information provided to investors before the creation of the SEC as a basis for rejecting the significance of Benston's finding. Fox states that the NYSE did not require audited financial statements until 1932 and notes their absence in the Exchange's 1925 manual. ${ }^{191}$ But the information in the NYSE 1925 manual for market practices up through to 1934 on which Fox

${ }^{188}$ Fox's source on the quality of the disclosure of sales data, the 1939 article by SEC staff attorneys, provides the following information on sales disclosures in firms' income statements: Of the 70 firms in Kaplan \& Reaugh's sample, supra note 169, the number of firms disclosing net sales after the 1934 Act approximately doubled (31 compared to 17 firms, including 3 firms that disclosed both gross and net sales either before or after the Act). Id. at 945 n.42. The number of firms disclosing gross sales, "sales" and "sales and operating revenue" is virtually unchanged (a rise from 22 to 23 firms), and 2 firms stopped disclosing net sales after the Act. Id. These data suggest that the quality of disclosure did not significantly increase after the Act. Furthermore, Kaplan and Reaugh do not indicate whether the new post-Act disclosers of net sales were pre-Act disclosers of gross sales, and not pre-Act nondisclosers and, correspondingly, whether the unchanged number of gross sales disclosers post-Act were the same firms as the pre-Act disclosers of gross sales rather than nondisclosers. Yet such distinctions are essential for Fox's hypothesized explanation of Benston's data to be correct. Hence Fox's contention that the 1934 Act should not have had a price effect because it improved the quality of all firms' disclosures is not credibly supported by his data source.

${ }^{189} I d$. at 949 n.59. There was virtually no change in the middle category that included selling, general and administrative expenses (an increase from 16 to 19 firms), $i d$., an item whose disclosure Kaplan and Reaugh consider crucial for computing the cost of goods sold, $i d$. at 950 .

${ }^{190}$ Benston, supra note 182 , at 142 n.12.

${ }^{191}$ Fox, supra note 3, at 1376, 1376 n.99. 
relies is, in fact, grossly misleading. Benston's research indicates that the vast majority of NYSE firms' financial statements were audited before the NYSE required the practice in 1932 (82\% were audited in 1926 and 94\% in 1934, for example), ${ }^{192}$ and other sources from the 1930s indicate that at least $85 \%$ of NYSE firms were audited before enactment of the 1934 Act. ${ }^{193}$ In fact, entrepreneurs have been voluntarily submitting to independent audits for centuries. Ross Watts and Jerold Zimmerman detail the voluntary use of independent auditors dating from thirteenth-century merchant guilds and up through to the earliest known corporate forms, including joint stock companies, for centuries prior to the United Kingdom's codification of the six-hundred-year-old practice in 1844, and they note that audits of U.S. corporations occurred in the nineteenth century as well. ${ }^{194}$ If certified financial statements are a sign of the quality of disclosure, as Fox implies in his claim that they did not exist prior to the creation of the SEC, then Fox is doubly incorrect: not only is his claim that the SEC was necessary for investors to obtain certified financial statements false, but so is the claim that the level of voluntary disclosure was of inadequate quality. ${ }^{195}$

Another example that Fox provides to convey a "sense of the magnitude of the problem" of inadequate disclosure, the failure of the NYSE to mandate disclosure of depreciation, ${ }^{196}$ is equally misplaced as a criticism of Benston's study. Benston found that $71 \%$ of NYSE firms disclosed depreciation in 1926, and this figure undoubtedly understates the level of disclosure in later years, as by 1934, the year of the federal legislation and the thus the last filing year before the 1934 Act took effect, it was up to $93 \% .{ }^{197}$ For instance, we do not know how many investors were able to obtain such information privately nor whether the nature of the assets of the non-disclosing firms was such that providing a depreciation figure would not be informative, compared to the disclosing firms (i.e., the bulk of the firms' assets were intangible and, hence, non-depreciated). Of course, as previously noted, the disclosure of depreciation is not particularly economically meaningful in the first place, given the lack of a connection between accounting depreciation measures and economic depreciation. It is therefore not

${ }^{192}$ Benston, supra note 183, at 519-20. It should be noted that the first required filing of financial statements under the 1934 Act was in July 1935.

${ }^{193}$ See Joel Seligman, The Transformation of Wall Street 48 n.32, 633 (1995).

${ }^{194}$ See Ross L. Watts \& Jerold L. Zimmerman, Agency Problems, Auditing, and the Theory of the Firm: Some Evidence, 26 J.L. \& Econ. 613 (1983).

${ }^{195}$ Another error in this regard is Fox's claim that Benston's only source of information regarding what firms disclosed or were required by exchanges to disclose was inquiries to the exchanges. Fox, supra note 3 , at 1376 . In fact, Benston not only surveyed the exchanges, but he confirmed firms' disclosure practices by using another data source, Moody's Manuals, a publication available to investors at the time, which contained the NYSE firms' financial information. Benston uses the data on firms from his earlier study, cited in supra note 183, in conjunction with his exchange surveys. Benston, supra note 182, at 142. Fox's dismissal of Benston's data by the claim that the NYSE provided self-serving, false information to Benston regarding auditing requirements is therefore irrelevant, as the NYSE is not the only source of information regarding pre-Act auditing practices.

${ }^{196}$ Fox, supra note 3, at 1378.

${ }^{197}$ Benston, supra note 183, at 519. 
apparent why Fox thinks revelation of this information would be of much significance to investors (let alone competitors under his interfirm externalities rationale for mandatory disclosure).

Fox's discussion of disclosure practices before and after the creation of the SEC with the 1934 Act does not, then, refute the validity of Benston's test of the impact of the 1934 Act and the SEC's mandatory disclosure on investor welfare: the proper test for a welfare improvement is whether there is a difference in the stock price impact on prior disclosers of sales information compared to prior non-disclosers. Sales information would have to be of no value to investors-which is inconsistent with Fox's critique of Benston's study that the level of voluntary disclosure before the 1934 Act was inadequate-for Fox's alternative hypothesis to be the correct prediction.

At a later point in his article, Fox restates his objection to Benston's study based on the adequacy of preAct disclosure somewhat differently. Rather than relating the quality of disclosure to the predicted hypothesis of the Act's price effects, Fox maintains that Benston's interpretation of his data-that the Act had no effect on firms' disclosures - cannot be correct because SEC proponents in the 1930s maintained that the SEC had a significant impact on disclosure. ${ }^{198}$ As evidence in support of this position, he cites in particular the finding in the 1939 article by SEC staff attorneys that 4 of 70 firms did not provide shareholders with income statements before the 1934 Act. ${ }^{199}$ However, Fox neglected to state that the same article also reports that 3 of 70 firms did not provide shareholders with income statements after the1934 Act as well. ${ }^{200}$ Not only is this an exceedingly small number of firms not providing income statements, but also the number of non-reporters was, for practical purposes, unchanged by the legislation. Moreover, as the article by the SEC staff attorneys further states, institutional investors and other substantial shareholders "often managed" to obtain financial information not otherwise published from firms prior to the Act. ${ }^{201}$ Since informed traders set the market price, individual investors would not have been harmed by the supposed inadequate financial disclosures that the SEC ostensibly remedied.

${ }^{198}$ Fox, supra note 3, at 1376.

${ }^{199}$ Id. at 1376-77 n.99.

${ }^{200}$ Kaplan \& Reaugh, supra note 169, at 940. Presumably the firms identified as not providing shareholders with income statements filed income statements, as required by the Act, with the SEC, but did not include that information in the annual reports provided to shareholders. As the NYSE also required income statements, it is probable as well that the four pre-Act non-disclosing firms in Kaplan and Reaugh's sample provided that information as required by the exchange but not directly to their shareholders. Supporting this conjecture is Benston's finding that $100 \%$ of NYSE firms reported their net income in 1926 as well as 1934, Benston, supra note 183, at 519, and it is improbable that the number would have decreased in 1930, the pre-Act year in Kaplan and Reaugh's study, as the time series data available in these studies show little aggregate change in disclosure practices. It should also be noted that the income data could have been available to investors without going to the stock exchange or, for that matter, in later years, to the SEC, because Benston's source for firms' financial data was Moody's Manuals. Id.

${ }^{201}$ Kaplan \& Reaugh, supra note 169 , at 937. 
Although many commentators in the 1930s believed that voluntary disclosures were inadequate and the SEC significantly improved disclosure practices, it is perilous to rely exclusively, as does Fox, on the characterization of the state of disclosure quality made by contemporaries of the SEC- most of whom were partisans in a pitched political battle in the midst of an economic depression-to measure its achievement. The assertions of such individuals should be handled with care because advocates of the legislation at the time were working from what have turned out to be mistaken premises regarding the economics and institutions of financial markets. Subsequent research has shown that many of the supposed factual premises that underpinned the rhetoric regarding the harms of the "unregulated" market that produced the federal securities legislation were, in fact, incorrect. Paul Mahoney, for instance, has demonstrated the fallacy of the claims motivating the enactment of the 1934 Act regarding rampant stock price manipulation by trading pools. ${ }^{202}$ In addition, Harold Bierman has investigated the manipulation claims motivating the federal securities legislation and concluded that there was little truth behind the claims. ${ }^{203}$ Finally, Benston concludes with a similar finding regarding the claims of rampant financial statement fraud, that there is little evidence that there were a significant number of cases of fraud in financial statements prepared prior to the enactment of the federal securities laws. ${ }^{204}$

Fox advances one other objection to the formulation of Benston's study of testing the welfare effects of the 1934 Act by examining stock price effects. He criticizes the very object of Benston's study, the 1934 Act, by questioning the significance of the Act compared to the 1933 Act with respect to mandated disclosure. His claim is that because the 1933 Act had more severe civil liability sanctions than the 1934 Act, firms did not have to comply with the 1934 Act, and this is supposed to explain Benston's failure to find a significant impact. Fox makes this comparison in order to conclude that it is "a particular danger" to view a study of the impact of the 1934 Act as suggestive of the value of the legislation today. ${ }^{205}$ In other words, we are supposed to give credence to the argument that even if the 1934 Act had no impact on stock prices, if we could redo Benston's test today, we would uncover an impact, because of an increase in civil sanctions.

Although a counterfactual cannot be disproved, there is nothing to suggest that Fox's speculation is

${ }^{202}$ See Paul G. Mahoney, The Stock Pools and the Securities Exchange Act, 51 J. Fin. Econ. 343 (1999) (finding that the pattern of price changes was unrelated to pool trading and to what we would expect were the pools manipulating prices). See also Paul G. Mahoney, The Political Economy of the Securities Act of 1933, 30 J. Legal Stud. 1 (2001) [hereinafter Mahoney, The Political Economy of the Securities Act] (explanation of the 1933 Act's prohibition of new issue gun-jumping as a means to reduce competition in favor of established investment banks rather than as an investor protection device). In addition, the federal regulation of futures markets, initiated in the 1920 s, was similarly grounded in a flawed understanding of those markets. See Romano, supra note 19, at 293-95, 30710.

${ }^{203}$ See Harold Bierman, Jr., The Great Myths of 1929 and the Lessons to Be Learned 133-45 (1991).

${ }^{204}$ Benston, supra note 182 , at 135 ; Benston, supra note 183 , at 517-18.

${ }^{205}$ Fox, supra note 3 , at 1373-74 n.91. 
correct. First, Fox provides no evidence that firms flouted the 1934 Act, and if they had, it would be inconsistent with his thesis that the Act had an impact on the quality of disclosure. Further undermining this particular critique, it should also be noted that the 1933 Act with its higher civil sanctions also had no price effect. ${ }^{206}$ Second and more important, in today's markets, there is an extensive industry producing information about firms, and the vast majority of investors are sophisticated institutions. These factors render far less important both government-mandated disclosure and the threat of civil sanctions today than in the 1930s, when, according to Fox, firms were ignoring the SEC's mandates with impunity. Hence, if there is a reason not to draw conclusions from studies of the impact of the 1934 Act, it would not be because a change in government sanctions makes the Act more potent today, but, rather, because improvements in information technology and the development of new financial intermediaries and supporting institutions make the Act of far less importance today, which undercuts Fox's position.

Moreover, there is considerable research on the impact of SEC-imposed disclosure requirements post1934, in the more contemporary era for which Fox's objection to empirical data because of a low probability of civil liability is inapplicable. The findings of the more recent studies are, in fact, in accord with those of Benston's study. The numerous studies investigating the SEC's adoption of segment reporting requirements in 1969 have failed to identify any stock price effect. ${ }^{207}$ In addition, studies of the SEC's mandated disclosure of the replacement cost of assets in 1976 find that the change had no effect on stock prices. ${ }^{208}$ Thus, as with the sales disclosure mandate of the 1934 Act, neither of these more recent mandates provided new information regarding firm values. The data regarding the absence of a price effect from SEC disclosure regulation are, accordingly, consistent over time: the SEC's mandates have not been directed at producing information of value to investors beyond what was being voluntarily produced.

$b$. The inappropriateness of the use of variance of stock returns as the standard of investor welfare. In response to the data that the 1934 Act had no impact on stock prices, Fox contends that mandatory disclosure of new information should not effect returns, but, rather, should effect the variance of returns. ${ }^{209}$ This is an assertion that Fox invokes several times in his article. This claim, however, misunderstands and misuses the literature.

${ }^{206}$ See infra notes $222-23$ and accompanying text.

${ }^{207}$ See supra note 175 and accompanying text.

${ }^{208}$ See Ross L. Watts \& Jerold L. Zimmerman, Positive Accounting Theory 174, 174 n.9 (1986) (citing studies).

${ }^{209}$ Fox, supra note 3, at 1375. Indeed, Fox recharacterizes Benston's study as an investigation of the risk of stocks around the enactment of the 1934 Act in contrast to how Benston viewed his study, as first and foremost a study of the Act's impact on prices. See Benston, supra note 182, at 137 ("If the SEC's disclosure requirements are meaningful, the statements they require should contain information and .... [the effect] should be reflected in 
For instance, Fox uses a quote from George Stigler that price dispersion is a measure of ignorance in the market, in support of his claim that a reduction in the variance of stock returns after the enactment of the federal securities laws indicates that they improved investor welfare. ${ }^{210}$ The Stigler quotation is, however, being misused with respect to the findings in Benston's study of the 1934 Act, as well as studies of the 1933 Act, which Fox is grouping together in his reference to Stigler. Stigler was not referring to the size of the variance in the return of a stock over time when he refers to dispersion, but rather, he is discussing dispersion in the price of a good offered by different sellers-the frequency distribution of prices quoted by sellers for a particular good at a single period of time (such as, to use Stigler's example, the asking price of a Chevrolet by Chicago auto dealers in 1959). The use of the term dispersion in the disparate settings as a measure of informativeness to purchasers is inaccurate. An appropriate use in a stock market setting would be the dispersion across bid-and-ask prices of a stock's market makers; a reduction in this dispersion is not, however, what is measured by the stock return variance in the studies being critiqued by Fox.

Stigler's contribution was to show that consumer search reduces price dispersion and that the optimal level of search equates the marginal cost of search and its marginal expected return (a better price). Stigler discussed mechanisms by which dispersion is reduced (or search is subsidized), such as advertising prices and development of specialized traders, and concluded that it would be "wholly uneconomic entirely to eliminate [ignorance's] effects." ${ }^{11}$ Stigler's conclusion is at odds with the view that Fox apparently is espousing, that government intervention is necessary to mitigate a consumer search problem that results in large disparities in a good's prices depending on sale location. Moreover, in Stigler's own empirical research on the federal securities laws, he expressly did not view a reduction in variation in stock prices as evidence that the federal regime had a beneficial impact on investors and, instead, hypothesized that such an effect would be evidenced by an increase in stock returns. $^{212}$

Stigler shares the view that is the consensus among financial economists, namely, that the stock market efficiently processes information such that small investors do not have to engage in a search for price protection. $^{213}$ It is textbook learning that in an efficient market, new information that is of value to investors

changes it its (a corporation's) stock prices").

${ }^{210}$ Fox supra note 3, at 1370 (quoting from Stigler's classic 1961 article The Economics of Information).

${ }^{211}$ George J. Stigler, The Economics of Information, 69 J. Pol. Econ. 213, 224 (1961).

${ }^{212}$ George J. Stigler, Public Regulation of Securities Markets, 37 J. Bus. 117 (1964).

${ }^{213}$ A recent survey of financial economists indicated that there is consensus on the efficient market hypothesis. Ivo Welch, Views of Financial Economists on the Equity Premium and on Professional Controversies, 73 J. Bus. 501 (2000). If a stock has multiple listings, then there might be price dispersion, but this is not relevant to the issue that Fox is discussing, since the stocks investigated in the studies on the enactment of the federal securities laws were single market listings. In addition, price differentials in the context of a multiple listing have little to do with the level of disclosure by issuers, which is Fox's concern, but, rather, have to do with broker execution 
affects stock prices, not their variance. ${ }^{214}$ The relevant measure of risk that affects value in modern finance theory is not firms' total variance, the measure on which Fox focuses, but market (systematic) risk. ${ }^{215}$ Moreover, where firm-specific measures have been found empirically to affect returns, the variance of returns is not a significant variable; rather, price-to-earnings and market-to-book value ratios are significant. ${ }^{216}$ Diversified investors will not pay a premium for a reduction in own-firm variance, and hence information affecting the firmspecific risk of a security will not be incorporated in stock prices, because diversification eliminates this risk.

Fox highlights the 1934 Act's impact on variance rather than return because Benston found that the total variance of returns decreased, although the market risk or sensitivity of returns in relation to market movements (beta) - the only risk of concern to investors in modern finance theory-increased after the Act. ${ }^{217}$ But Benston further found that there was no difference in the change in variance across the two groups of firms in his sample, the pre-Act disclosers and non-disclosers of sales data. Namely, the firms for which the Act's mandate had bite, the pre-Act non-disclosers of sales, did not experience a greater reduction in variance than those that had always disclosed sales. In fact, the variance of the nondisclosers was slightly lower than that of the pre-Act disclosers, in both the pre- and post-SEC periods. Because the decline in variance occurred for both sets of firms and not simply for the firms whose disclosure was impacted by the Act, Benston concluded that the 1934 Act did not affect the variance in stock returns. ${ }^{218}$

Even if we accept Fox's, rather than Benston's, interpretation of the significance of the variance data-that the standard for a welfare gain from a variance effect does not require a differential effect on the variance of preAct disclosers and that of non-disclosers-it is important to note that a reduction in variance across-the-board does not demonstrate that government intervention to mandate disclosure is required to improve investor welfare. Interpreting the data most favorably to Fox's position, a reduction in variance could suggest that the 1934 Act had an effect of standardization - the spread in stock returns decreased because the SEC's disclosure regulation facilitated investor comparison of firms. But such a finding is not evidence that the SEC was necessary for

costs and secondary exchanges' lower costs of operation compared to the primary market such as the NYSE, which is the principal location of price discovery for the shares. See, e.g., Jonathan R. Macey \& Maureen O'Hara, Regulating Exchanges and Alternative Trading Systems: A Law and Economics Perspective, 28 J. Legal Stud. 17, 29-30 (1999).

${ }^{214}$ See, e.g., Ross et al., supra note 6, at 319-26.

${ }^{215}$ See id. at 255-61, 273-81.

${ }^{216} I d$. at 270.

${ }^{217}$ Benston, supra note 182 , at 144-45, 149.

${ }^{218} I d$. at 149. It should further be noted that the decline in variance occurred either in mid-1933 or mid-1936, depending on how one views the scatterplots of the data, neither of which years can readily be associated with an impact from the 1934 Act. George J. Benston, Required Disclosure and the Stock Market: Rejoinder, 65 Am. Econ. Rev. 473, 475 (1975). 
standardization. ${ }^{219}$ To the contrary, product standardization has, for instance, occurred in contemporary financial markets - the unregulated financial derivatives sector developed its own standard form contract for swaps — as well as in numerous non-financial sectors, such as electronics, without government intervention. More importantly, stock exchanges can implement uniform standards for securities disclosure, and when the federal securities laws were enacted in the 1930s, such efforts had been under way at the NYSE for some time. ${ }^{220}$

Government intervention might be called for if the market were to adopt a standard that is sub-optimal. But such an outcome is scarcely to be expected in the securities disclosure context, given the multiplicity of repeatplay financial intermediaries who stand to gain from the choice of a better standard and given the ability of exchanges, a natural source of disclosure standards through listing requirements, to internalize the costs and benefits of uniform disclosure where a single firm would not because exchanges "own" the marketplace on which the firms trade. Most important, even if government regulation is necessary to provide a standard, competing regulators are not an obstacle to the accomplishment of standardization of disclosure. In the United States, for example, there are fifty state corporation codes, but there is substantial uniformity in their substantive content. ${ }^{221}$

${ }^{219}$ Fox appears to be aware that state intervention is not a prerequis ite for standardization, because he does not make such an argument — the need for standardization-when he advocates the necessity for mandatory disclosure by a single regulator; he relies on the need to address interfirm externalities. Standardization involves a financial, and not a real, externality, because it does not have an impact on firms' cash flows. The concern that Fox emphasizes is the disclosure of information relating to real rather than financial externalities. Dye's model suggests that regulation is unnecessary in the context of financial externalities because in that context, voluntary disclosure and mandated disclosure generally produce the same outcome. Dye, supra note 84 , at 15 . The exception is when the utility of a risk-averse disclosing firm's entrepreneur is not equally weighted in the social welfare function with the utilities of other entrepreneurs and investors, but this is an objective function inconsistent with Fox's approach to social welfare, which focuses on the gains to other firms even at the disclosing firm's expense, and would therefore not overweight the disclosing firm's welfare. Moreover, if the undiversified entrepreneur is risk-neutral, then there is also no divergence between voluntary and mandatory disclosure outcomes, regardless of the utility function weights. Id. Admati and Pfleiderer view standardization as of at most "secondary importance" to the issue of mandatory disclosure, because the need for a standard does not imply a need for government action, as firms have incentives to adopt a standard on their own. Admati \& Pfleiderer, supra note 85, at 513-14. Finally, as earlier noted, a decline in variance after the 1933 Act is not a welfare improvement if it is due to fewer price changes because less useful information is being produced. See supra note 178.

${ }^{220}$ See Mahoney, supra note 186, at 1469-70 (discussing turning point for NYSE disclosure requirements beginning in 1910 with the abolishment of unlisted trading).

${ }^{221}$ See supra note 27 and accompanying text. Despite the efforts of the International Accounting Standards Committee ("IASC"), there is, at present, substantial diversity in national accounting standards. Fox contends that this is evidence that each nation's firms are so inherently different that different rules by national origin are appropriate. See Fox, supra note 13. A related argument is made by Stephen Choi and Andrew Guzman, that because of territorial-based regulation, this diversity is an imperfect reflection of a need for diversity in standards across firms, which is not correlated with firms' national origins but firm-specific characteristics. Choi \& Guzman, supra note 23. These contentions may well be true. However, another plausible explanation of the diversity in international accounting standards is the lack of effective regulatory competition: when domestic firms are captive registrants because of a prohibitive cost to transferring regimes (the loss of the home capital market), national regulators can more easily retain inefficient accounting rules as they will not lose firms to a regulator with superior rules. See supra 
In addition, all of the states have accepted the accounting standards adopted by the Financial Accounting Standards Board ("FASB") in the exercise of their licensing power over the accounting profession, while they could have applied different rules for solely local (in-state) businesses, as they have done with respect to the registration requirements for new issues.

It is important to conclude by clarifying what is at issue in the dispute over the findings regarding stock price and variance in Benston's study and, accordingly, the significance of his research for regulatory competition. The issue regarding the efficacy of the single regulator system is not whether a regulator can possibly identify additional items beyond what firms will disclose voluntarily. Because information production is costly, a regulator can always identify an item that has not been voluntarily disclosed by all firms and might be of use to a hypothetical investor. The issue is, however, whether such additional disclosures are cost-justified from investors' perspectives. None of Fox's criticisms of Benston's study are directed at this question, and this is a serious failing. Benston's finding that stock prices did not increase upon the SEC's enhanced disclosure requirements is strongly suggestive that the market's cost-benefit calculation was, in fact, correct, that is, the information was either already available or it was not of sufficient value to investors to justify the cost to firms in disclosing it. This should not be surprising: markets are particularly well-suited for making such judgments.

\section{Event Studies of the 1933 Act}

Several studies have sought to determine the impact of the 1933 Act on the value of new issues, the most celebrated and earliest of which was conducted by George Stigler. ${ }^{222}$ All of the studies, which compare new issue prices before and after the legislation over varying lengths of time thereafter, find that the 1933 Act had no price effect. $^{223}$ Under textbook finance theory, this suggests that as was true of the 1934 Act, the 1933 Act did not provide investors with meaningful new information.

Fox dismisses the significance of the event studies of the 1933 Act, contending that we should not expect to see a price effect from the Act's newly-mandated disclosure, because inadequate disclosure prior to the

notes 14-17 and accompanying text. Thus, the SEC can refuse to implement accounting rules favored by other regulators that are members of the IASC, because U.S. firms must comply with the accounting rules the SEC approves and cannot choose to operate under another accounting system. If there were international securities regulation competition, then there would automatically be competition for accounting standards as well, and uniformity in the standards for at least multinational firms might be reached quite rapidly.

${ }^{222}$ Stigler, supra note 212; Gregg A. Jarrell, The Economic Effects of Federal Regulation of the Market for New Securities Issues, 24 J.L. \& Econ. 613 (1981); Carol J. Simon, The Effect of the 1933 Securities Act on Investor Information and the Performance of New Issues, 79 Am. Econ. Rev. 295 (1989).

${ }^{223}$ The only exception is one subsample in Simon's study, unseasoned issues traded on regional exchanges, which experienced higher returns after the Act. Simon, supra note 222, at 304-05. But this subsample also performed significantly worse in both periods than the other new issues in her study, $i d$. at 308 , so it is difficult to conclude that the Act was of much help even to the investors in this subset of firms. 
legislation would have been impounded in stock prices and equalized returns before and after the Act. ${ }^{224}$ This position is inconsistent with Fox's contention that mandated disclosure was necessitated by the inadequacy of the disclosure produced by the market. For if voluntary disclosure is inadequate, then returns should have improved after the 1933 Act; investors would have no longer been misled about firm values and improperly pricing the securities. The relative rate of return on new issues should have increased after the Act compared to the rate of return on such issues before the Act had the Act solved an information failure in the new issues market.

Fox further contends, as he argued regarding the 1934 Act, that the effect of the 1933 Act should be a reduction in investors' risk and not an improvement in returns. ${ }^{25}$ But as earlier discussed, this contention is incorrect. The impact that would be reasonably expected if a disclosure provides new information-the rationale for mandating disclosure, that the information was not released voluntarily —is an improvement in returns and not in variance. This is textbook learning on the operation of capital markets-they are efficient such that the public disclosure of a new piece of information that affects investors' assessments of a firm's future cash flows will immediately be impounded into the stock's price. ${ }^{226}$ There is only no price effect if the datum s not informative-if it does not alter investors' valuations of the firm. Accordingly, the event studies imply that the proponents of the Act were simply wrong in their assumption of the new issue capital market's serious imperfections or of the remedial efficacy of the legislation.

While the event studies of the 1933 Act do not uncover any price effect, the variance of the returns of new issues declined. ${ }^{227}$ In Fox's view, the reduction in total variance post-1933 evinces investors' ability to estimate firms' futures cash flows improved after the legislation. However, as I discussed in my prior article, there is suggestive data that the reduction in risk after the 1933 is not an indication that investors were able to make better forecasts due to the mandated disclosure, but rather, a result of the elimination of high-risk firms from public capital markets. ${ }^{228}$ In particular, Gregg Jarrell has found that there was a decrease in the proportion of outstanding new issues of common stock to debt after the 1933 Act and that there was a dramatic increase in the private

${ }^{224}$ Fox, supra note 3, at 1382. Fox raises some additional objections to the studies that are not well founded. He wrongly implies that Stigler and Jarrell are comparing new issues with secondary offerings; both compare the returns of new issues before and after the Act, adjusted for the return on the market as a whole. Stigler, supra note 212, at 120, Jarrell, supra note 222, at 630-32. Fox also objects to testing for a price effect from new information by adjusting individual stock returns for market movements, on the grounds that individual rates of returns are equalized so absolute returns should be studied. This objection is inconsistent with elementary principles of modern finance, that stock returns are determined by their relation to market risk and that whether a datum is new information, such that it produces an abnormal return, can be identified by adjusting the return for the simultaneous impact of the market's movement. See, e.g., Ross et al., supra note 6, at 281-83, 319-30.

${ }^{225}$ Fox, supra note 3, at 1370.

${ }^{226}$ See supra notes 214-15 and accompanying text.

${ }^{227}$ Stigler, supra note 212; Jarrell supra note 222; Simon, supra note 222.

${ }^{228}$ Romano, supra note 2, at 2377. 
placement market for debt of high-risk bonds. ${ }^{229} \mathrm{He}$ also has found that there were fewer high-beta (that is, high market-risk) new issues after the Act than before it, a clear indication of fewer high-risk offerings post-1933. ${ }^{230}$ The only explanation that reconciles all of these findings is that the 1933 Act led to a decrease in public offerings with high risk. This explanation is important because a reduction in the variance of returns due to a contraction in investors' opportunity set after the legislation is not a welfare improvement. To the contrary, because investors merely require higher compensation to invest in securities with greater risk, the restricted availability of financing for high-risk ventures by the loss of access to public markets entails a net social loss.

Fox offers no evidence to refute the explanation of the variance decline as due to withdrawal of high-risk issues from the public sector. He instead advances the "suspicion" that the Depression caused an increase in debt. ${ }^{231}$ Fox's suspicion, however, is not pertinent for Jarrell's data, which distinguish across the risk of the debt issues. In particular, Fox does not explain why the Depression, which had begun four years prior to the enactment of the 1933 Act, would have increased the issuance of debt (in hard financial times and with many bank failures, for instance, one would expect that it would have been more difficult for firms to borrow during the Depression and that debt issuance would have declined rather than risen) or why, as Jarrell found, the Depression would have affected the composition of debt across markets, that is, forced higher-risk debt to be privately rather than publicly marketed after 1933. Fox simply does not have an explanation of the data that are at odds with his position regarding the efficacy of the 1933 Act.

Fox's final argument to counter the contention that the reduction in variance post-1933 indicates that the Act adversely affected the public issuance of high-risk securities is to assert that there is no "obvious" reason why the 1933 Act would have shifted the issues with the greatest risk away from the public sector. ${ }^{232}$ In my prior article, I provided one explanation for why risky offerings would have shifted away from public markets after the enactment of the 1933 Act, the hypothesis of Seha Tinic, that the 1933 Act's liability regime deterred high-risk issues from coming under the Act, because the Act subjected underwriters to strict liability and the possibility of poor performance is higher for issues with greater risk. ${ }^{233}$ Tinic advanced this thesis to explain the welldocumented phenomenon that IPOs are underpriced and offered evidence that the new offering discount increased after 1933. But Tinic provided more suggestive data supporting the explanation of the 1933 Act's

${ }^{229}$ Jarrell, supra note 222, at 661, 664, 667, 669.

${ }^{230} I d$. at 648. Simon did not undertake an investigation similar to Jarrell's. But she does note that the unregulated over-the-counter market for stock issues increased significantly after the 1933 Act and suggests that the "extent to which SEC regulation shifted riskier securities to unregulated markets is an important issue to be addressed in future research." Simon, supra note 222, at 313.

${ }^{231}$ Fox, supra note 3, at 1371 n.83.

${ }^{232} I d$.

${ }^{233}$ Seha M. Tinic, Anatomy of Initial Public Offerings of Common Stock, 43 J. Fin. 789 (1988). 
variance reduction as removing issues with high risk from the market: a showing that the new securities that reputable underwriters, who have the most to lose from litigation, were willing to offer shifted after the 1933 Act to larger issues with less risk. ${ }^{234}$

Fox criticizes Tinic's litigation-avoidance thesis as an explanation of the variance results by contending that the discount for a new issue post-1933 is too high to be explained by the cost of liability. ${ }^{235}$ But litigation costs do not have to explain the entire discount of new issues for the thesis to be correct that the new liability standard under the securities laws affected the desirability of underwriting risky issues. Underpricing could be a function of numerous underwriter reputational concerns, of which lawsuit damages is only one component. In other words, Tinic's thesis and data support Jarrell's conclusion regarding the impact of the 1933 Act on market composition, whether or not they explain what Tinic set out to explain, namely, IPO underpricing. Moreover Fox's criticisms are not directed at the more suggestive evidence in Tinic's study in support of the hypothesis that the 1933 Act removed the riskier issues from the public sector, the shift in offering sponsorship by reputable underwriters to less risky issues post-1933.

In addition to the litigation-avoidance explanation already noted, there are other explanations for why the 1933 Act could have pushed high-risk issues out of public markets. For example, another possible explanation involves the restrictions the SEC placed on the accounting information that could be revealed in the documents for public debt. The SEC followed the conventional conservative bias in accounting and required the use of historical cost as opposed to market value of assets, prohibited the use of appraisals and earnings forecasts, and led the campaign to eliminate goodwill from balance sheets. ${ }^{236}$ To the extent that it is more important for high-risk firms to convey such information to investors in order to obtain the best issue price than it is for low-risk firms, the agency's disclosure policy would force high-risk firms into the private placement market, where they could continue to provide the prohibited information.

Suggestive data on this hypothesized impact on high-risk firms of the accounting requirements of the Act are provided in a study by George Benston, in which he investigated which industries used private debt most

${ }^{234}$ Id. at 813 .

${ }^{235}$ Fox, supra note 3, at 1372 n.83. Fox's related criticism regarding Tinic's insurance hypothesis is puzzling. Fox questions why one would give up a dollar today to be sure that one is not sued for a dollar tomorrow. Id. That is what firms generally do when they buy liability insurance. Fox should instead consider questioning the rationale for having a liability insurance industry rather than Tinic's hypothesis of self-insurance; presumably in the 1930s, it was cheaper for underwriters to drop riskier issues than to purchase liability insurance, as insurance would have been quite costly because there would not have been an actuarial baseline from which insurers could set premiums. There are data to support such a speculation: an important factor contributing to the crisis in directors' and officers' liability insurance in the 1980s was increased legal uncertainty. See Roberta Romano, What Went Wrong with Directors' and Officers' Liability Insurance?, 14 Del. J. Corp. L. 1, 21-30 (1989).

${ }^{236}$ See, e.g., Benston, supra note 183 , at 526. 
frequently for new issues after the 1933 Act (a market that largely did not exist before 1934). Benston found that the post-1933 private issuers tended to be in industries for which, according to his rankings, conservative accounting is misleading and, consequently, were those industries for which the SEC's reporting requirements could produce a negative bias in investors. ${ }^{237}$ These were extractive industries, where historical cost of property is less meaningful and appraisals of estimates of oil in the ground are the critical data for valuation, and transportation and retail firms, where intangibles like monopoly franchises and goodwill are major assets. Unfortunately Benston did not measure industry risk, and hence we cannot conclude from his findings that the accounting explanation of why the legislation would remove risky issues from public markets is correct. But as with Tinic's data, Benston's data imply that the federal securities laws affected the composition of offerings.

I will conclude this discussion by noting one other possible explanation for a decrease in the risk of new issues after the 1933 Act. Many of the procedures established for public underwriting in the 1933 Act were directed at protecting the interests of more established sectors of the financial industry (wholesale investment banks) over newer interests (integrated retailers). ${ }^{238}$ The Act's distributional impact on the financial industry provides an even more straightforward explanation for why there would be a decline in public offerings of highrisk issues after the Act. The legislation appears to have driven out of business many smaller regional underwriters, who tended to handle high-risk issues. ${ }^{239}$

Supporters of the SEC such as Fox may find none of the explanations advanced for why the 1933 Act would force high-risk issuers out of the public market (the Act's strict liability for underwriters, the SEC's conservative accounting disclosure requirements, or the adverse impact on regional underwriters) persuasive, but they are all coherent explanations. More important, they are entirely consistent with the data regarding the impact of the Act on stock returns and variances, as well as Jarrell's additional data related to high-risk issues. Fox's explanation of the variance effect of the Act as indicating a change in the accuracy of stock value assessments rather than a change in the composition of public issues, in contrast, cannot explain Jarrell's findings regarding high-risk issues; it only explains the finding of a general reduction in the variance of returns after 1933.

But even if we were to reject Stigler's and Jarrell's market composition explanation of the change in variance around the 1933 Act, in favor of Fox's conjecture, as earlier discussed, finding a variance reduction from the legislation does not demonstrate that the Act (and, derivatively, mandatory disclosure by a single

${ }^{237}$ Id. at 527-28.

${ }^{238}$ See Mahoney, The Political Economy of the Securities Act, supra note 202.

${ }^{239}$ Id. at 28-29. Mahoney, who provides persuasive evidence of the distributional effect of the 1933 Act, notes that Henry Manne suggested that the 1933 Act helped, rather than hurt, the major investment banks, "who underwrote low-risk securities and ... had nothing to lose from a 'full disclosure policy' and much to gain from driving out underwriters of high-risk securities." Id. at 2. 
regulator) was a welfare-increasing policy step. First, the variance reduction detected in the studies of the 1933 Act was a measure of firm-specific risk and not market risk. Textbook finance theory teaches that the risk that is priced is market risk, and hence, investor wealth is not affected by a reduction in firm-specific risk. ${ }^{240}$ Consequently, the reduction in variance of the 1933 Act cannot be characterized as improving investor welfare. Second and correspondingly, if there is no price effect from a mandated disclosure, then the requirement did not provide new information concerning future cash flows. It was either already available in the marketplace or of no value to investors.

A reduction in variance, without a price effect, implies that the 1933 Act at best had the impact of a standardization of the disclosure for new issues - at worst it means that the Act reduced the level of reliable information being produced, which would have lowered stock return variance because prices change less frequently when new information is not revealed in a timely fashion. But it bears repeating that even under the most benign interpretation of the data's effect on investors, standardization does not require a single regulator or a mandatory regime; it can be and is accomplished voluntarily. ${ }^{241}$ Additional evidence in support of this assertion can be gleaned from Carol Simon's 1933 Act study. Simon found that the Act's greatest impact on variance was for the small issues that were not traded on the NYSE. ${ }^{242}$ One explanation for the smaller effect on NYSE firms is that the NYSE was already providing such a standardizing function comparable to the SEC. There is no plausible reason to believe that satisfactory uniform practices would not have been developed by the stock exchanges had there not been the federal legislation.

\section{The Impact of SEC Financial Disclosure and Transaction Review on Stock Valuation}

In addition to the classic studies by Benston and Stigler on the impact of the original federal securities legislation, a recent paper by Kirsten Ely and Gregory Waymire provides further evidence that the SEC's disclosure policy has not been value-enhancing. Ely and Waymire examine the pricing of NYSE shares with respect to financial information provided by firms before and after the SEC. ${ }^{243}$ They find that the explanatory power of earnings and book values for prices in the pre-SEC era is not significantly different from that under the regulation of the FASB and its predecessors, the entities to whom the SEC delegated the power to establish accounting principles. The

${ }^{240}$ See supra notes 215-16 and accompanying text.

${ }^{241}$ See supra notes 219-21 and accompanying text.

${ }^{242}$ Simon, supra note 222, at 309-10.

${ }^{243}$ Kirsten Ely \& Gregory Waymire, Accounting Standard-Setting Organizations and Earnings Relevance: Longitudinal Evidence from NYSE Common Stocks, 1927-93, 37 J. Acct. Res. 293 (1999). They randomly selected one-hundred NYSE firms for each of the sixty-seven years between 1927-1993 and examined the explanatory power of yearly cross-sectional regressions of market-adjusted stock returns on annual earnings changes and levels. Id. at 301-02. 
introduction of accounting standard-setting bodies and changes in the standard-setting process, including the reduction in diversity of accounting practices in the 1960s to improve interfirm reporting comparability, did not significantly improve "earnings relevance," the explanatory power of earnings for the valuation of firms. ${ }^{244}$

The upshot of this study is that the impact of regulatory accounting standard-setting under SEC auspices on the informativeness (what Ely and Waymire term the "value-relevance" of earnings) of financial statements is not significant Ely and Waymire's findings further suggest that a single accounting standard-setter has difficulty identifying what accounting rules will produce relevant information. This goes to the heart of the argument for regulatory competition: its advantage in harnessing market incentives to ascertain cost-effective disclosure requirements.

Finally, an SEC advisory committee analyzed stock price data to determine whether investors benefit from the agency's review of registration documents prior to a public offering by a seasoned issuer. ${ }^{245}$ The hypothesis under study was that if the information generated by staff review is "predominantly negative," following the claims of advocates of mandatory disclosure and the review process that issuers will not voluntarily disclose negative information prior to an offering, then in an efficient market, SEC reviews should be associated with stock price declines during the course of the review, in contrast to offerings that are not subject to such review. ${ }^{246}$ The alternative hypothesis in the study was that the continuous disclosure of information by issuers renders unnecessary the SEC staff's separate review of transactional filings. The advisory committee found that there was no statistically significant difference in the average change in stock prices relative to the market according to whether or not filings were reviewed, consistent with the position that staff review of filings generates no new material information. ${ }^{247}$

The advisory committee's data are additional evidence that the SEC staff is not better able than investment professionals are at assessing the quality of a firm's disclosures, paralleling the conclusion to be drawn from the

${ }^{244}$ Consistent with Ely and Waymire's data, James Davis, Eugene Fama, and Kenneth French show that the relation between stock returns, book-to-market ratios, and size is the same throughout the period 1929-1997. James L. Davis et al., Characteristics, Covariances, and Average Returns: 1929-1997 (University of Chi. Graduate Sch. of Bus., Center for Research in Sec. Prices Working Paper No. 471, Feb. 1999). However, this study is not as probative on the SEC's efficacy as the Ely and Waymire study because Davis et al. group the data around the mid-point year 1963, and this will obscure any difference in the five-year pre-SEC and the twenty-nine-year post-SEC segments of their early period. But if the accounting rule changes to improve uniformity promulgated in the 1960's were more substantial than the other events that Ely and Waymire examine, including the SEC's creation, then the Davis et al. data, which, because they are investigating a totally different question, are centered around 1963, would be as informative regarding a monopoly standard-setter's effectiveness as Ely and Waymire's data.

${ }^{245}$ SEC Advisory Comm. on the Capital Formation \& Regulatory Processes, Final Report app. A at 15 (1996) [hereinafter SEC Advisory Comm. Report], available at http://www.sec.gov/news/studies/capform/.

${ }^{246} I d$. at 14.

${ }^{247}$ Id. at 15. 
previously discussed studies. In short, the agency is no better at determining what information should be disclosed than the market is. Perhaps a diehard advocate of the SEC would interpret the committee's finding as evidence of value added by the agency, by maintaining that all issuers disclose full information because of the threat of staff review. But such an explanation is simply implausible when evaluated in conjunction with all the other studies. It is far more plausible that the threat of liability for fraudulent disclosures is a more powerful motivator of issuers than SEC staff review. Such a threat would persist under regulatory competition.

\section{Studies of Firms' Voluntary Disclosures and Listing Choices}

Fox contends that the changes in the capital market since the enactment of the federal securities laws render studies of the 1930s legislation uninformative and that results of analogous studies of SEC-mandated disclosure in the changed market circumstances would be different. ${ }^{248}$ However, as previously discussed, the SEC's mandates of segment reporting in 1969 and replacement cost accounting in 1976 did not have any impact on stock prices, duplicating the findings regarding the 1930s legislation. ${ }^{249}$ Moreover, the change in capital market conditions since the 1930s ought to elicit genuine doubt regarding the need for a single regulator, because contemporary markets are dominated by institutional investors and there is far greater competition among financial intermediaries, producing information sources about securities that did not exist seventy years ago. Indeed, the private sector provides information concerning valuation beyond mandated SEC disclosures. Financial analysts' earnings forecasts, for instance, provide significant information to the market regarding equity valuation beyond firms' mandated disclosures. ${ }^{250}$

There is, more importantly, a literature on firms' voluntary disclosure choices in contemporary markets that provides compelling support for regulatory competition. This literature not only bolsters the findings regarding the failure of the 1930s legislation to provide information of value to investors that markets did not provide, but also contradicts Fox's additional objection to competition that "managers [will] prefer as low a level of periodic disclosure as possible," as well as related "race-to-the-bottom" concerns of other critics of regulatory competition. $^{251}$

First, there is considerable evidence that firms voluntarily disclose significant amounts of information beyond that mandated by securities regulators. For example, the disclosure accompanying debt issued in the private placement market duplicates the disclosure of public debt, even though that higher level of disclosure is not

${ }^{248}$ See Fox, supra note 3, at 1373-74.

${ }^{249}$ See supra notes 175, 208 and accompanying text.

${ }^{250}$ Amir et al., supra note 12.

${ }^{251}$ Fox, supra note 3, at 1411; Trachtman, supra note 70; see also Cox, supra note 3 (raising the possibility of "race-to-the-bottom" concern over regulatory competition in securities law). 
required. ${ }^{252}$ In addition, European firms listing in London typically comply with U.K. disclosure requirements, which are higher than Continental requirements, even though they could instead comply with their home-states' regimes under the European Union directives. ${ }^{253}$ European firms engaging in international-style offerings in the institutional market, which is not subject to formal disclosure requirements, disclose even more information than is required by any European nation, selecting a level of disclosure closer to U.S. disclosure standards. ${ }^{254}$ Furthermore, the listing requirements of the newly created Neuer Markt in Germany consist of greater disclosure than those of the older stock exchanges, such as the Frankfurt Stock Exchange, in response to shareholder demand, and its market has prospered. ${ }^{255}$ Although the identity of the listings - technology and other growth companies - undoubtedly accounts for much of the exchange's success, the Neuer Markt is actively engaged in satisfying investor preferences, having, for example, amended its listing requirements when investors raised concerns that listed companies were flouting the exchange's lock-up rules. ${ }^{256}$ Finally, in the unregulated hedge fund market, information services have been established that collect investment information from numerous hedge fund managers, calculate the fund values and risk, and then market the information to investors. ${ }^{257}$ Extensive voluntary disclosure is not a new or unusual phenomenon: as earlier discussed, before the enactment of the federal

${ }^{252}$ Trevino, supra note 7. It is possible that these issuers are responding not only to investor desires for more information but also to potential liability under Rule 10b-5, which applies to private placements as well as public issues and could lead the issuers to follow public issue disclosure requirements because precedents involving public securities will set disclosure standards for private issues too. See William J. Carney, Jurisdictional Choice in Securities Regulation, Va. J. Int'1 L. (forthcoming 2001) (manuscript at 8). But regardless of the disclosure motive, as William J. Carney notes, the extraordinary depth of the private market suggests that the SEC regime imposes high costs on issuers, so that they have exited from the regulated public market, $i d$. (manuscript at 9). The cost of the regime may also be perceived by investors, as they no longer require a substantial discount to purchase debt securities offered in the private market, see SEC Advisory Comm. Report, supra note 235, at 52-53.

${ }^{253}$ See Gary K. Meek \& Sidney J. Gray, Globalization of Stock Markets and Foreign Listing Requirements: Voluntary Disclosures by Continental European Companies Listed on the London Stock Exchange, 20 J. Int'l Bus. Stud. 315 (1989) (sample of European companies trading in London); Hal S. Scott \& Philip A. Wellons, International Finance Transactions, Policy, and Regulation 311 (7th ed. 2000) (references concerning Danish and French firms' compliance with U.K. standards).

${ }^{254}$ See Jackson \& Pan, supra note 8 (interviews regarding capital raising practices with twenty-eight European lawyers whose firms included eight of the ten leading advisers to issuers by deal value and eight of the thirteen leading advisers by deal number and who were advisers on over sixty European offerings in 1999).

${ }^{255}$ Vanessa Fuhrmans, Playing by the Rules: How Neuer Markt Gets Respect, Wall St. J., Aug. 21, 2000, at C1.

${ }^{256} \mathrm{Id}$.

${ }^{257}$ Craig Karmin, Investors' Desire for Hedge-Fund Data Prompts New Firms to Peddle Specifics, Wall St. J., Feb. 22, 2001, at C16. Many large investors, such as the World Bank or the California Public Employees' Retirement System, require periodic specified disclosures of the hedge funds in which they are invested. Id. Such developments are a market response to the collapse a few years ago of the hedge fund Long-Term Capital Management, which engaged in minimal disclosure, especially of its unusually high leverage. It was able to operate so secretively because of investor demand to participate in the fund given an initial stellar performance and illustrious staff. For a chronicle of the fund's demise, see Roger Lowenstein, When Genius Failed (2000). 
securities laws, NYSE firms disclosed considerable financial information and provided certified audited statements, as businesses had voluntarily been doing for centuries. ${ }^{258}$

Consistent with these data on voluntary disclosure practices, investment analysts assign rankings to U.S. firms not simply according to the adequacy of their mandatory disclosures but also according to their voluntary disclosures. ${ }^{259}$ This feature of the analysts' rankings indicates that the practice of disclosing more than required is common even for domestic firms subject to the SEC's regime. These data indicate that regulators have not divined the optimal mix of disclosure in their mandated regimes and provide evidence that fears of a race to the bottom resulting in no or little disclosure were firms free to choose their disclosure regime are thoroughly unfounded. ${ }^{260}$

Second, the quantity and quality of firms' voluntary disclosures are positively correlated with stock issuances and stock prices. ${ }^{261}$ In other words, increased voluntary disclosure reduces firms' cost of capital. The

${ }^{258}$ See Benston, supra note 183 (detailing NYSE firms' disclosure and auditing practices before the federal legislation); Watts \& Zimmerman, supra note 194 (detailing voluntary use of independent auditors back to thirteenthcentury guilds and up through the earliest known corporate forms, including joint stock companies, for centuries before the United Kingdom codified the 600-year practice in 1844, and noting audits of U.S. corporations occurred in the nineteenth century as well).

${ }^{259}$ Christine A. Botosan \& Marlene A. Plumlee, Disclosure Level and Expected Cost of Equity Capital: An Examination of Analysts' Rankings of Corporate Disclosure 7 (University of Utah Working Paper, Jan. 2000). (The Association for Investment Management and Research evaluates corporate reporting practices by assigning ranks to firms according to the adequacy of their reporting in three disclosure categories: annual reports and other mandated disclosures, weighted at 40\%-50\%; quarterly reports and other voluntary disclosures, weighted at 30\%-40\%; and "other aspects," which refers to "access to management through presentations to analysts, company-sponsored field trips and interviews," weighted at 20\%-30\%.)

${ }^{260}$ Furthermore, voluntary disclosures often include information, such as improved segment reporting, that ought to be of special interest to Fox, as he believes such information entails interfirm externalities. See Paul Healy et al., Stock Performance and Intermediation Changes Surrounding Sustained Increases in Disclosure Strategy, 16 Contemp. Acct. Res. 485, 495 (1998) (commonly cited reasons for analysts increasing a firm's disclosure ranking include improvements in segment disclosures). These data further suggest either that the private cost-benefit calculation is not as disparate from the social cost-benefit calculation with respect to interfirm externalities as Fox maintains, or that he has misidentified which data contain significant proprietary information.

${ }^{261}$ See, e.g., id. at 498, 503, 508-09 (sustained improvements in voluntary disclosure results in improved stock performance and also is positively associated with stock issuances); Richard Frankel et al., Discretionary Disclosure and External Financing, 70 Acct. Rev. 135, 141 (1995) (firms significantly more likely to forecast earnings if they access capital markets over sample period); Mark Lang \& Russell Lundholm, Cross-Sectional Determinants of Analyst Ratings of Corporate Disclosures, 31 J. Acct. Res. 246, 265, 269 (1993) (financial analyst federation disclosure quality rating increases with security issuance); William Ruland et al., Factors Associated with the Disclosure of Managers' Forecasts, 65 Acct. Rev. 710, 720 (1990) (firms reporting forecasts more likely to issue new capital); Frederick D.S. Choi, Financial Disclosure and Entry to the European Capital Market, 11 J. Acct. Res. 159, 168-70 (1973) (firms entering Eurobond market increase disclosure); Christine A. Botosan, Disclosure Level and the Cost of Equity Capital, 72 Acct. Rev. 323, 344, 346 (1997) (voluntary disclosure in annual report significantly explains cost of capital of firms with small analyst following). Although one could interpret the data indicating that disclosure increases in conjunction with new issues as implying that the incentive for managers to disclose information in secondary trading markets is inadequate, see, e.g., Palmiter, supra note 22, at 107, that would be an improper inference 
numerous studies supporting this assertion indicate that disclosure is valued by investors and that firms competing for capital respond to those preferences. Thus, the market provides incentives for managers to disclose information to investors beyond what is mandated by regulators. There is no reason to believe that this behavior would be any different in a competitive international securities regime and that managers would suddenly move to regimes requiring no or minimal disclosure. Rather, they would shift to regimes with disclosure mandates that are most consistent with the preferences of their investors.

Third, increases in the level of voluntary disclosure, as well as in the overall quality of disclosure, reduce the bid-ask spread in a stock's price and correspondingly improve the stock's liquidity. ${ }^{262}$ Both effects are beneficial for investors and thus lower firms' cost of capital. This is a further reason why managers have incentives to provide information to investors, whether or not there is a mandatory regime. In fact, managers release information voluntarily when there is greater information asymmetry between the firm and investors regarding its value, as measured by the bid-ask spread, in order to reduce that asymmetry and thereby increase the value of the shares. ${ }^{263}$

Increases in voluntary disclosure may not, however, always be beneficial for a firm. A study by Brian Bushee and Christopher Noe finds, for example, that improvements in voluntary disclosure attract institutional investors with a high propensity to trade and thereafter increase the disclosing firms' stock volatility, which the authors consider to be undesirable.$^{264}$ However, it should be noted that Bushee and Noe also find that increased

to draw. Increases in disclosure are also associated with benefits for secondary market trading, such as reductions in bid-ask spreads, see infra note 262, and with managerial equity-based compensation, see supra note 52. In addition, some studies find that increased disclosure comes with a cost of higher volatility related to a change in ownership pool, see infra notes 264-267, suggesting that it could be cost effective to raise disclosure levels only when seeking new capital.

${ }^{262}$ See, e.g., Healy et al., supra note 260 (sustained increases in voluntary disclosure result in increased liquidity); Michael Welker, Disclosure Policy, Information Asymmetry, and Liquidity in Equity Markets, 11 Contemp. Acct. Res. 801 (1995) (firms with high analyst disclosure ratings have smaller bid-ask spreads than firms with lower ratings).

${ }^{263}$ See, e.g., Carol A. Marquardt \& Christine I. Wiedman, Voluntary Disclosure, Information Asymmetry, and Insider Selling through Secondary Equity Offerings 16, 19-20, 22 (John M. Olin Sch. of Bus., Washington Univ. Working Paper No. 97-05, Apr. 1997) (in secondary offerings, managers act as if reduced information asymmetry is correlated with reduced cost of capital, such that their participation in an offering explains the frequency of voluntary disclosure); Maribeth Coller \& Teri Lombardi Yohn, Management Forecasts and Information Asymmetry: An Examination of Bid-Ask Spreads, 35 J. Acct. Res. 1, 6-8, 10 (1997) (firms with increasing bid-ask spreads release earnings forecasts to reduce spread); Shuping Chen et al., Voluntary Disclosure of Balance Sheet Information in Quarterly Earnings Announcements (University of S. Cal. Working Paper, May 2000) (managers more likely to make voluntary balance sheet disclosures when earnings are less informative to reduce information asymmetry), available at SSRN Electronic Paper Collection, http://papers.ssrn.com/sol3/papers.cfm?abstract_id=216469.

${ }^{264}$ See Brian J. Bushee \& Christopher F. Noe, Unintended Consequences of Attracting Institutional Investors with Improved Disclosure (Harvard Bus. Sch. Working Paper No. 00-033, Oct. 1999). They consider increased volatility undesirable because it could increase the likelihood of a lawsuit, increase the firm's perceived riskiness and hence its cost of capital, or make incentive compensation less effective. Id. at 5. 
volatility is positively related to relative stock performance, presumably a desirable occurrence for firms. . ${ }^{265}$

Additional support for Bushee and Noe's interpretation of their data and a negative effect of increasing disclosure can be inferred from a study by Christine Botosan and Marlene Plumlee examining the relation between disclosure levels and the cost of capital. They find, unexpectedly, that in a sample of large firms, in contrast to earlier research on small firms, a higher analyst ranking for voluntary disclosure leads to a higher cost of capital (although a higher ranking for mandatory disclosure leads, as expected, to a lower cost of capital). ${ }^{266}$ Botosan and Plumlee explain this result as consistent with Bushee and Noe's analysis, because the voluntary disclosures leading to the higher rankings are principally quarterly reports, which offer more timely disclosure of information and are of interest to institutional investors who seek to trade on short-term earnings reports. ${ }^{267}$ Although Bushee and Noe are examining the effects of changes in disclosure rankings while Botosan and Plumlee are investigating absolute disclosure levels, Botoson and Plumlee's hypothesis is that the presence of investors who engage in aggressive trading could produce increased stock volatility for high voluntary disclosure firms, which would explain the higher cost of capital that they find.

The findings of the studies by Bushee and Noe and by Botosan and Plumlee suggest that care should be taken in assuming that all increases in disclosure, including voluntary disclosure, will improve investor welfare. When evaluated in conjunction with the rest of the literature, this line of research implies that the benefit of improved liquidity from increased disclosure could be offset by the cost of an increase in "transient" investors who have high portfolio turnover, leading to future increases in volatility. ${ }^{268}$ However, as firms are repeat players in capital markets, we would not expect managers to continue a practice of increased disclosure if such costs were to outweigh the benefits to the firm. Moreover, given the relative incentives of managers and bureaucrats to avoid error in this context, there is little reason for confidence that a government agency would do a better job at cost-benefit calculation than firms.

Ascertaining the net effect of voluntary disclosure on volatility and share value is not, however, the critical issue for regulatory reform. The issue is whether firms persistently disclose only the minimal amount of information that is required and, hence, whether there will be inadequate disclosure in a competitive regulatory

${ }^{265} I d$. at 17 . When disclosure changes in the subsequent year (that is, the year in which the change in volatility is measured) were included in the analysis, while the institutional investor variable was still positively related to volatility, neither period's disclosure variable was significant. Id. at 20. This suggests that the increase in volatility following an increase in disclosure is not simply due to the improvement in market efficiency (more price adjustments) from the enhanced disclosure.

${ }^{266}$ Botosan \& Plumlee, supra note 259 (in a sample of large firms, those with higher rating of required disclosure have lower cost of capital, but greater voluntary disclosure is associated with higher cost of capital).

${ }^{267}$ Id. at 23-24.

${ }^{268}$ Bushee \& Noe, supra note 264, at 6. 
environment, the concern that motivates the parade of horribles recited by opponents of regulatory competition. ${ }^{269}$ The literature on firms' voluntary disclosure practices demonstrates in a convincing fashion, in my judgment, that there is no cause for such a concern. The international and domestic evidence is overwhelming that firms provide a substantial amount of information to investors regardless of the regulatory regime. Firms persistently engage in greater disclosure than regulators require. They also do not migrate, when a choice of securities regime is possible, to the regime requiring the least amount of disclosure. ${ }^{270}$

In the United States, regulation has ironically even hindered the voluntary disclosure of information that is of critical import to investors. For example, the SEC for decades banned earnings forecasts, information far more significant to investors than the historical accounting data that are the focus of SEC mandates. ${ }^{271}$ More economically savvy regulators than the SEC have recognized that market participants are often better informed than they are, and adapted their regulatory strategies accordingly. The Federal Reserve Board and other central banks, for instance, have adopted an approach to capital requirements for market risk that relies on financial institutions' internal measurement models rather than the regulatory style of a governmentally-mandated

${ }^{269}$ E.g., Cox, supra note 3; Trachtman, supra note 70. Fox suggests that disclosure will be too "low" in a competitive regime, but he does not provide the details of what information firms would stop disclosing that investors, as opposed to the SEC, deem important; presumably he is referring to information regarding interfirm externalities. E.g., Fox, supra note 3, at 1396 (“[each issuer] will choose [a regime] requiring significantly less disclosure"). He also maintains that capital will be inefficiently allocated under regulatory competition. Id. at 1362 . These objections are a rehash of his interfirm externalities rationale for disclosure regulation, which, as discussed in supra Part III.B, is not only theoretically flawed but also cannot practicably be implemented. Moreover, there is no evidence that a single regulator allocates capital efficiently. The most vibrant sector of the U.S. economy, hightechnology, for instance, is not initially financed under the SEC's regulatory auspices but, rather, is financed by private placements through venture capital firms. See Gompers \& Lerner, supra note 106.

${ }^{270}$ It should be noted that some commentators mistakenly believe that this fact reveals an absence of effective regulatory competition and not its essence. See John C. Coffee, Jr. et al., The Direction of Corporate Law: The Scholar's Perspective, 25 Del. J. Corp. L. 79, 99 (2000) (foreign firms' choice to come under the stricter disclosure rules of U.S. listing means that regulatory arbitrage does not work) (remarks of John C. Coffee, Jr.). As this paper has repeatedly pointed out, regulatory competition does not result in the lowest level of disclosure. It is odd that commentators who have praised the ability of foreign firms to choose the U.S. regime instead of their home regulator have not sought to extend choice to U.S. firms. There is no coherent rationale for distinguishing U.S. from non-U.S. firms in this manner: there is no evidence that U.S. managers are more likely to exploit shareholders or that their investors are less informed than those of foreign firms, to require mandatory, rather than optional, coverage by the SEC. Just as foreign firms tend not to select the lowest level of disclosure that is available, neither will U.S. firms if they can choose their regulatory regime. Indeed, if the SEC were to lose its territorial monopoly, both U.S. and nonU.S. firms that are under the SEC's regime today might choose another sovereign, which, spurred by the gains from competition, would better calibrate the costs and benefits of disclosure regarding investor needs than the SEC.

${ }^{271}$ This policy was subject to sustained criticism in the 1970 s, with one of the objections, ironically, that it disadvantaged individual investors, as firms could not make public forecasts of earnings but could discuss them privately with analysts and institutions. See, e.g., Homer Kripke, Can the SEC Make Disclosure Policy Meaningful?, 2 J. Portfolio Mgmt. 32, 35-37 (1976). Eventually the SEC modified its position, but its limited safe harbor induced fear of liability and, consequently, did not increase significantly the public disclosure of forecast information. For a brief discussion of the SEC policy regarding forecasts, see Romano, supra note 2, at 2378-80. 
formula. ${ }^{272}$ The proposal for regulatory competition in securities law is motivated by a similar judgment as that which motivated the central bankers of the benefits of harnessing market incentives to the regulatory apparatus.

\section{The MARKET FOR CORPORATE LAW IN THE UNITED STATES AS A PARADIGM FOR INTERNATIONAL \\ SECURITIES REgULATION}

Information concerning firms' voluntary disclosure choices provides insight into what a competitive securities regime would look like. But it is, at best, still very much an educated guess. Even the EU's mutual recognition arrangement for stock listings is not the stuff of true competition, because all EU securities regimes must meet specified minimum standards. There is, however, one context in which firms can and do choose their legal regime without restriction: the choice of corporate law in the United States. The rules governing relations between managers and shareholders are within the jurisdiction of the states, and the state recognized with jurisdictional authority over a firm is the firm's chosen statutory domicile. ${ }^{273}$ The experience of investors under this regime is instructive for the prospect of competition among international securities regulators. This is because the interests and incentives in the two settings are similar: the object of protection of both regimes is the financial interest of investors, and under competition, investors' preferences will dictate the choice of regulator because insiders who require investment capital will bear the higher capital cost of an investor-unfriendly regime choice.

There are compelling data that shareholders have, on balance, benefited from the competitive charter regime in the United States. ${ }^{274}$ This implies that investors would fare equally well under securities regulatory competition. After briefly providing an overview of the empirical literature on U.S. charter competition that supports the case for extending competition to securities law, this Part addresses questions that have recently been raised concerning the efficacy of state competition. These include whether there is effective competition

${ }^{272}$ See Federal Reserve System Ris k-Based Capital Standards: Market Risk, 12 C.F.R. pts. 208,225 (2001) (enacted Sept. 1996) (implementing amendments to the Basle Accord reached by central bankers for market risk, relying on firms' internal methods to measure value-at-risk). The banking regulators adopted this approach because the private sector had information superior to that of the regulators concerning the risk measurement of investment portfolios, as the banks had internal incentives to develop the most accurate techniques and the technology was improving so rapidly that regulators could not keep up.

${ }^{273}$ The United States follows a choice-of-law rule that recognizes a statutory domicile for corporate law, as do most countries operating under the British common law tradition, in contrast to most Continental European countries, which follow a real-seat rule that requires a significant physical presence in the jurisdiction for domicile recognition. The significance of a recent decision of the European Court of Justice, Case C-212/97, Centros Ltd. v. Erhvervs-og Selskabsstyrelsen, 1999 E.C.R. I-1459, upholding a firm's use of a statutory domicile under EU treaty principles, for the continued validity of the real-seat rule will be resolved by litigation in progress (comments by European corporate law scholars at Siena Conference on Company Law and Capital Market Law, March 2000).

${ }^{274}$ The data are reviewed in infra Part IV.A. 
across the states for charters because of Delaware's dominant share of incorporations ${ }^{275}$ and the related question whether there are network effects in corporate law that undermine competition or have led to the enactment of inefficient codes, as well as whether securities law is qualitatively different from corporate law such that charter competition is not an apt analogy. It concludes by responding to a long-standing contention that the experience with state regulation of hostile takeovers is evidence that charter competition should be abandoned in favor of a national regime analogous to the federal securities laws administered by the SEC.

\section{A. The Evidence that State Competition for Charters Benefits Shareholders}

A good proxy for ascertaining whether firm choice of legal regime under competition benefits investors is the effect upon shareholder wealth of a domicile switch. If a change in domicile increases firm value, it would be exceedingly difficult to maintain that charter competition is harmful to shareholders. Of course, because in the United States, reincorporation is subject to shareholder approval, it would be surprising to find firm value declines upon a domicile change. Critics of state competition have either overlooked this fact276 or contended that shareholders are ignorant, irrational, or coerced when they vote in favor of a domicile change,277 particularly when the new domicile is Delaware, which, as the dominant incorporation state, is often cast as the villain in the race-to-the-bottom explanation of competition, as an enactor of laws that facilitate managers' exploitation of shareholders. However, this is not a plausible scenario of the circumstances of voting on domicile changes by U.S. equity holders. As earlier noted, these voters are primarily sophisticated institutions holding large portfolios, who are situated within a well-developed investor communication network and hence are repeat players in proxy votes, such that the cost of being informed about different legal regimes in order to vote intelligently on a reincorporation is quite low. ${ }^{278}$

${ }^{275}$ Delaware is the predominant choice of domicile of publicly traded corporations and particularly of reincorporating firms. For example, in my study of reincorporations between 1960 and 1983 of both NYSE and overthe-counter firms, over $80 \%$ of the reincorporations were in Delaware, Romano, supra note 21, at 244, and in Dodd \& Leftwich's earlier study of reincorporations of NYSE firms between 1927-1977, 90\% were in Delaware, Peter Dodd \& Richard Leftwich, The Market for Corporate Charters: "Unhealthy Competition" vs. Federal Regulation, 53 J. Bus. 259, 263 (1980). In addition, in 1996, 56\% of NYSE firms were incorporated in Delaware (data provided to author by Robert Daines).

${ }^{276}$ Cary, supra note 71.

${ }^{277}$ Bebchuk, supra note 25, at 1471.

${ }^{278}$ See supra notes 55-56 and accompanying text. Reincorporations do not present prisoner dilemma problems that arguably could accompany shareholder voting on dual class stock recapitalizations or bondholder voting on amendments to the indenture in insolvency recapitalizations, referred to as exit consents, see, e.g., Gordon, supra note 87 (dual-class stock); John C. Coffee \& William A. Klein, Bondholder Coercion: The Problem of Constrained Choice in Debt Tender Offers and Recapitalizations, 58 U. Chi. L. Rev. 1207 (1991) (exit consents), because they do not bundle the vote with an increased cash payout that is forfeited if the investor votes no or if the proposal is not approved by a majority. The bundling issues that can arise include the selection of Delaware itself, an 
There have been eight studies investigating the effect on stock prices of a change in incorporation state. ${ }^{279}$ All of the studies find positive abnormal stock returns, with four finding a significant positive stock return at the time of the announcement of the domicile change; ${ }^{280}$ one finding a significant positive return for only a subset of reincorporations on the announcement date with different results on the subsequent shareholder meeting date; ${ }^{281}$

objection raised by Bebchuk and discussed at infra note 298 and accompanying text, or provisions in the new firm's charter that would otherwise have been the subject of a charter amendment, a possibility discussed at infra note 293.

${ }^{279}$ Event studies use standard econometric techniques to determine the impact on stock prices of new information. When the date on which the information is released is known and the sample size is large, the methodology is well-specified to identify abnormal returns of even a few percentage points; for example, the power of the statistical test for a sample of 100 firms to pick up an abnormal return of $1 \%$ or higher is $100 \%$; for 50 firms, the power of the test at a $1 \%$ return is $94 \%$ and $100 \%$ for a $2 \%$ return. See A. Craig MacKinlay, Event Studies in Economics and Finance, 35 J. Econ. Literature 13, 29 (1997). The eight event studies of reincorporations are: Michael Bradley \& Cindy A. Schipani, The Relevance of the Duty of Care Standard in Corporate Governance, 75 Iowa L. Rev. 1 (1989); Dodd \& Leftwich, supra note 275; Randall A. Heron \& Wilbur G. Lewellen, An Empirical Analysis of the Reincorporation Decision, 33 J. Fin. \& Quantitative Analysis 549 (1998); Allen Hyman, The Delaware Controversy-The Legal Debate, 4 J. Corp. L. 368 (1979); Jeffry Netter \& Annette Poulsen, State Corporation Laws and Shareholders: The Recent Experience, 18 Fin. Mgmt. 29 (1989); Pamela Peterson, Reincorporation Motives and Shareholder Wealth, 23 Fin. Rev. 151 (1988); Romano, supra note 21; Jianghong Wang, Performance of Reincorporated Firms (Nov. 1995) (unpublished manuscript). The event dates used in these studies are the date of the proxy statement, filed with the SEC and sent to the shareholders, that notices the meeting at which the reincorporation is being proposed for a vote, with additional tests run using the later date of the actual shareholders' meeting. In my event study, I also examined the price effect on the earliest possible public announcement dates, which are not available for many firms, the date of a board meeting approving the reincorporation, and the date of the incorporation of the shell subsidiary into which the firm is merged to effectuate the domicile change, which typically is the earliest date, preceding the proxy mailing by a month and the board meeting by a few days or weeks. Romano, supra note 21 , at $268 \mathrm{n} .62$. In an event study, it is desirable to identify the first public announcement date of the event under study - here, the reincorporation-in order to determine when investors would have first learned of the proposal, because in an efficient market, the effect of new information is immediately impounded into the price. The statistical tests continue to be well-specified when the announcement date is uncertain, and an interval around the suspected announcement date is used instead of one date. See Stephen J. Brown \& Jerold B. Warner, Using Daily Stock Returns: The Case of Event Studies, 14 J. Fin. Econ. 3, 14-15 (1985). For a discussion why the event studies discussed here--reincorporation event studies-- are the best evidence of the value of state competition compared to others-- event studies of judicial decisions or statute enactments, see Sanjai Bhagat and Roberta Romano, Event Studies and the Law: Part II Empirical Studies of Corporate Law (Yale International Center for Finance Working Paper No. 00-33, Apr. 2001).

${ }^{280}$ Bradley \& Schipani, supra note 279, at 66-67 (significant positive returns on event date and approximately one month before); Romano, supra note 21, at 270-71 (significant positive returns at three-day, one-week, and onemonth intervals before event); Wang, supra note 279, at 14-18, 21 (significant positive returns for full sample over three-day event interval; significant positive returns for Delaware firms over forty days before event; positive returns over three-day event interval significant only at $10 \%$ but significant at $5 \%$ if shareholder meeting date used as event for three-day interval; returns to Delaware firms consistently higher than those to non-Delaware firms, which are negative throughout most of event interval); Hyman, supra note 279, at 385 (significant positive returns four days before event, using difference-in-mean test between price changes or reincorporating firms and the S\&P index rather than a t-test of the abnormal returns).

${ }^{281}$ Heron \& Lewellen, supra note 279 , at 559 (table 6, clean sample of firms reincorporating to limit liability of directors). As discussed at infra notes 287-91 and accompanying text, this study found a significant negative effect for a subsample of firms reincorporating for takeover defensive purposes at the time of the shareholder meeting but not at the proxy mailing date, Heron \& Lewellen, supra note 279, at 557-58, but there is good reason not to place any 
another finding a significant positive return over two years prior to the reincorporation; ${ }^{282}$ and two finding positive returns that are significant at the $10 \%$ confidence level. ${ }^{283}$ These uniformly positive findings, in my judgment, are compelling evidence that competition benefits shareholders. In any event, one certainly cannot read this literature and conclude that state competition for charters is damaging to shareholder welfare.

However, because reincorporations are typically accompanied by changes in business plans, ${ }^{284}$ there is a question whether the positive stock price effects are evidence of the market's assessment of the change in business plan rather than the change in domicile. To examine whether the positive price effect was a function of investors' responses to other changes in business plan accompanying the reincorporation and not their evaluation of the new legal regime, I compared the returns of reincorporating firms grouped by the type of activity accompanying or motivating the domicile change: engaging in a mergers and acquisitions program; undertaking takeover defenses; and a miscellaneous set of other activities including reducing taxes. Although one might have expected the impact to vary across firms, with the antitakeover reincorporations experiencing negative returns, as prominent commentators have viewed defensive tactics as adverse to shareholders' interests, ${ }^{285}$ in fact, not only was the sign on that group's abnormal return positive, but there was no significant difference across the groups. ${ }^{286}$ This finding implies that the signific ant positive returns upon reincorporation are due to investors' positive assessment of the change in legal regime and not a confounding of the impact of reincorporating firms' other future projects.

In contrast to my findings, using a different event date, Heron and Lewellen find a different price reaction depending on whether the reincorporation is undertaken to limit directors' liability (significantly positive) or to erect takeover defenses (significantly negative). ${ }^{287}$ They interpret their results as indicating that some

credence in the result.

${ }^{282}$ Dodd \& Leftwich, supra note 275, at 272-75 (significant positive returns two years before event).

${ }^{283}$ Netter \& Poulsen, supra note 279, at 35-37 (positive returns one month around event that were significant at $10 \%$ level only); Peterson, supra note 279 , at 159 (return on day -1 , day +3 , and day +10 positively significant at $10 \%$ for subsample of 16 firms not reincorporating for takeover defense reasons; insignificant returns for full sample of 30 firms and 14-firm subsample reincorporating for takeover defense reasons).

${ }^{284}$ See Romano, supra note 21, at 250.

${ }^{285}$ E.g., Frank H. Easterbrook \& Daniel R. Fischel, The Proper Role of a Target's Management in Responding to a Tender Offer, 94 Harv. L. Rev. 1161 (1981

${ }^{286}$ See Romano, supra note 21, at 272 (analysis of variance test of cumulative residuals). Peterson also finds that the returns to firms reincorporating for antitakeover reasons are insignificant, while firms reincorporating for other reasons are significantly positive at the $10 \%$ level on a few event days. Peterson, supra note 279 , at 159 . She does not, however, test whether the returns across the different groups are actually significantly different. Given the small sample size (30 firms in total, 14 firms reincorporating for antitakeover purposes), the power of the test for the antitakeover reincorporations as well as the full sample is low. In addition, Peterson also does not indicate what announcement date she is using, which renders it difficult to assess the import of her results, see infra notes 290-91 and accompanying text, although they are consistent with my study's results.

${ }^{287}$ Heron \& Lewellen, supra note 279 , at 557-59. 
reincorporations are undertaken to increase share value (the director liability limitation group) and others to entrench management (the defensive tactic group). There are, however, a number of problems with Heron and Lewellen's interpretation of the data. The takeover defense firms' abnormal returns are significant only on the shareholder meeting date and not on the earlier proxy mailing date. This is odd, given the results of the other reincorporation studies, ${ }^{288}$ which detect significant positive effects on proxy mailing dates, and given the efficient market hypothesis, under which adverse information regarding a move should have been incorporated in the stock price at the earliest public announcement date. ${ }^{289}$ More important, the use of the meeting date as the event date is highly problematic for event study analysis, which throws doubt on the reliability of the finding. James Brickley's investigation of the event study methodology found that random samples of annual meeting dates - that is, a sample on which there is no a priori reason to find a significant price effect—produce significant abnormal returns, in contrast to random samples of proxy mailing dates. ${ }^{290}$ Brickley's explanation of the finding of abnormal returns on randomly selected meeting dates in contrast to mailing dates is that annual meeting dates are well-known in advance and often contain important management announcements (such as earnings forecasts), which can produce abnormal returns because "risk and expected returns can increase around predictable events likely to contain information." 291 This result indicates that Heron and Lewellen's finding of abnormal returns on the annual meeting date, but not on the proxy mailing date, is, in all likelihood, a spurious finding regarding the impact of the reincorporation.

A further shortcoming with Heron and Lewellen's interpretation of their data is that they mistakenly assert in their article that the reincorporating firms' takeover defenses could only have been undertaken in Delaware. ${ }^{292}$ However, all of the defenses they identify as adopted by the reincorporating firms—fair price and supermajority

${ }^{288}$ It should be noted that I found that cumulating the abnormal returns around later dates, compared to earlier dates, resulted in higher statistical significance levels, although there was no change from insignificance to significance in my groups. Romano, supra note 21, at 272.

${ }^{289}$ See Ross et al., supra note 6, at 319-30. One potential explanation of the different results in my and Heron and Lewellen's studies is the different time-periods of our samples. I do not, however, think that this explanation is correct. Heron and Lewellen's sample overlaps with the Netter and Poulsen and Wang studies, which find positive price effects. Although Wang does not classify reincorporation types, Netter and Poulsen separately examine, as a proxy for defensive tactic reincorporations, a sample of California emigrations, which is a better indicator for a move based on a difference in takeover regime than the firm-level defenses in the Heron and Lewellen subsample, since the latter defenses were valid in all states including Delaware, except for staggered boards, which were prohibited in California during the Netter and Poulsen sample period, see infra notes 293, 296, and part of the Heron and Lewellen sample period. Netter and Poulsen found a positive stock price effect significant at $10 \%$, a result that is the opposite of Heron and Lewellen's finding and similar to mine, while their sample period overlaps with that of Heron and Lewellen's and not my sample. Netter \& Poulsen, supra note 279.

${ }^{290}$ See James A. Brickley, Interpreting Common Stock Returns around Proxy Statement Disclosures and Annual Shareholder Meetings, 21 J. Fin. \& Quantitative Analysis 343, 346-47 (1986).

${ }^{291}$ Id. at 347-48.

${ }^{292}$ Heron \& Lewellen, supra note 279, at 554. 
charter amendments, staggered boards, elimination of cumulative voting and poison pills - could have been undertaken in any state at the time of their study and were not exclusively available in Delaware. ${ }^{293}$ This error undermines the claim that the reincorporation was essential for adopting a takeover defense-in contrast, for example, to firms emigrating to a state with a takeover statute that did not exist in the state of origin, as was true for many firms in my study of reincorporations. ${ }^{294}$

A possible explanation for adoption of some, although not all, of the antitakeover charter provisions that Heron and Lewellen identify upon a move to Delaware is that the firms were not adding new protections but, rather, were maintaining existing protections, because the default rules in Delaware are more favorable to bidders than the rules in other states, and hence the firms could require a charter provision to obtain equivalent protection. ${ }^{295}$ Consonant with this critique of Heron and Lewellen's analysis, Netter and Poulsen, using the more

${ }^{293}$ The only exception is for firms emigrating from California, for which staggered boards were prohibited until 1989 (roughly two-thirds of their sample period), when California amended its corporation code to eliminate the mandatory application of cumulative voting and permit staggered boards. See Cal. Corp. Code $\S \S 301,301.5$ (Deering 2000) (providing legislative history 1989 Amended Stat. ch. 876, §§ 1-2). Heron and Lewellen do not indicate how many, if any, of their takeover defense firms were reincorporating from California. Moreover, Delaware's takeover statute could not have been an important motivation for reincorporation, as virtually all states had takeover statutes equal to or stricter than Delaware's statute during the period of the study. See Romano, supra note 22, at 59, 67. Heron and Lewellen's conclusion that the reincorporations accompanied by adoption of takeover defenses are exercises of managerialism may be correct, but it is beside the point for the debate over competition-the managers of these firms did not need to reincorporate in Delaware to adopt takeover defenses. The only relevant concern is the possibility that by bundling the takeover defenses into one vote on a domicile change, rather than subjecting them to separate votes as charter amendments, management is more likely to garner sufficient shareholder support for the defenses. Because the proxy materials for a reincorporation must clearly describe any changes with respect to takeover defenses under the new domicile, including the new charter, it is possible, but, in my judgment, improbable, that bundling the takeover defenses in the new charter of the reincorporated firm enabled management to obtain majority support, which would not have been attained in separate voting on defenses as charter amendments. The increase in shareholder votes against antitakeover tactics probably began after 1987, the year institutional investors began offering shareholder proposals, many of which were directed at defensive tactics, see, e.g., Del Guercio \& Hawkins, supra note 141, at 296-97, which is the final third of Heron and Lewellen's sample period, although a majority of the sample reincorporations occurred during that period. Given institutional investors' opposition to particular defenses in recent years, it seems highly improbable that they would approve a domicile switch if it were to result in a defense, such as a staggered board, that the firm would otherwise lack. Moreover, many of the defenses Heron and Lewellen specify, such as fair price and supermajority provisions, are not considered particularly potent and thus would not be of concern to voting investors. See, e.g., Stuart L. Gillan \& Laura T. Starks, Corporate Governance Proposals and Shareholder Activism: the Role of Institutional Investors, 57 J. Fin. Econ. 275, 286 (2000) (of 2,042 shareholder proposals offered from 1987 to 1994, 249 involved rescinding poison pills while only 24 involved repealing fair price or supermajority provisions). Heron and Lewellen do not provide a breakdown of the sample firms' defenses to resolve this question, and they separately examine only poison pill defenses, the one defense that managers can adopt at any time, without shareholder approval, and hence a defense not relevant to the bundling hypothesis.

${ }^{294}$ Romano, supra note 21.

${ }^{295}$ See John C. Coates IV, An Index of the Contestability of Corporate Control: Studying Variation in Legal Takeover Vulnerability (July 17, 1999) (unpublished working paper) (Delaware has lowest ranking in index based on statutory default rules with respect to ability to defend against hostile bids). For example, Heron and Lewellen refer to 
appropriate proxy mailing date as the event, found that the stock price effect of reincorporations to Delaware from California, the one state arguably more favorable to bidders than Delaware given the fact that it does not have a takeover statute and it prohibited staggered boards and required cumulative voting during the period covered by the Netter and Poulsen study, was insignificantly positive. ${ }^{296}$

The difference across reincorporation subsamples in Heron and Lewellen's study cannot readily be interpreted as evidence that the positive effects of reincorporation found in other event studies are indicia of investors' valuation of confounding events-a change in business plans accompanying domicile changes-- rather than the value of the new legal regime and hence of state competition. The reincorporations in the Heron and Lewellen study for which there was a significant positive price effect were, in fact, undertaken solely to take advantage of the new domicile's legal regime—the ability to limit directors' liability—and were not accompanied by any announced change in business plan. It is possible that investors interpret such moves as an indication that the company is planning to engage in a transaction that typically leads to frivolous litigation that would be prevented by the limited liability provision. But even this explanation of Heron and Lewellen's finding is consistent with interpreting the positive price effects as due to the Delaware legal regime, rather than a confounding event (the expected, albeit unspecified, transactions): it is due to the regime's beneficial effect on the cash flows accruing to firms from particular transactions by reducing the probability of litigation. Indeed, one could extend this logic to question whether we should be concerned about the possibility of confounding events in event studies that consist of a reincorporation and a new business plan motivating the reincorporation. Namely, if the new domicile reduces the cost of undertaking a new business strategy, such as a mergers and acquisition program, that investors consider a value-increasing event, then, because the value to the firm of that new strategy would have been less under the old domicile's regime and it would not have been undertaken without the reincorporation, a positive price effect identified by the event study includes the value of both the strategy and the

the adoption of fair price and supermajority charter amendments, Heron \& Lewellen, supra note 279, at 554; such defenses are part of many states' corporation codes but not Delaware's. In this regard, a negative stock price reaction could be interpreted as disappointment by investors that the reincorporating firms were not obtaining the maximum benefit—facilitation of a bid—of a domicile change to Delaware; but such a reaction should still have been incorporated into stock prices on the proxy mailing, not meeting, date, as the authors provide no evidence that there was any uncertainty surrounding the outcome of the vote, to distinguish this subset of reincorporations from those of all other event studies. Heron and Lewellen state that for a subset of firms they used only firms that gained additional defenses upon reincorporation by adding a charter amendment or opting into a takeover statute, $i d$. at 558, but they do not indicate whether they checked for differences in the default rules in the original state code compared to Delaware that would necessitate a specific provision in a Delaware charter compared to the original state charter.

${ }^{296}$ Netter \& Poulsen, supra note 279, at 35-36. California removed the limitation on staggered boards in 1989, see supra note 293, and in contrast to Heron and Lewellen's sample, Netter and Poulsen's sample of reincorporations all occurred in 1986-1987. 
cost advantage of operating under the new regime.297 Thus one cannot separate out the two effects because the two events are inextricably connected, and both are positively contributing to firm value. The possibility of confounding events poses an interpretive problem only if the hypothesized signs of the events differ (so that a large positive effect of one event could mask a small negative effect of the other)—which is not the case when the destination state's regime reduces the new business strategy's cost. Thus, it is most plausible to conclude that the positive price effects identified in the reincorporation studies represent investors' valuation of the new legal regime and thereby indicate that investors view a domicile change as value-enhancing.

Some scholars question the appropriateness of using event study methodology for assessing the efficacy of state competition beyond the issue raised by the potential confounding in the stock price of a domicile change and a change in business operations at the time of reincorporation. For instance, Lucian Bebchuk has asserted that stock price studies are not probative on whether state competition benefits shareholders, because state competition may produce some provisions that are harmful to shareholder interests even if the overall package of provisions is not, and hence we would not detect a negative price effect upon reincorporation. ${ }^{298}$

Bebchuk's critique is not a troubling objection to the use of event studies in determining whether competition is preferable to a centralized federal statute. This is because his premise of offsetting price effects in which shareholders are being forced to choose between bundles of good and bad statutes would be troubling only if the statistical findings of the event studies were uniformly insignificant, indicating that the bundled codes are in equipoise between good and bad provisions. Yet, as discussed, nearly all event studies report significant positive price effects. His alternative contention that any significant positive results are due to confounding events, as previously discussed, is incorrect as well. Most important, from the perspective of a corporate code and the efficacy of the output of competition, it is the net wealth effect of a code on investors that is important, and that effect is positive.

Although it may be possible for a scholar to identify a specific provision of a corporate code that he or she believes is value-decreasing compared to his or her own proposed legislation, it is difficult to imagine any realworld political process that would do a better job at enhancing share value than the competitive process in which Delaware is the prominent incorporation state. This is what the event study data reveal. Bebchuk does not, for

\footnotetext{
${ }^{297}$ For an explanation that firms reincorporate to reduce the transaction costs of new business undertakings see Romano, supra note 21, at 249-251.

${ }^{298}$ Bebchuk, supra note 25 , at $1449-50$. He also speculates that event studies will not identify a negative effect if the old and new domiciles' laws are the same. Id. This hypothesis is mistaken. The hypothesis could be correct only if the price effect of a reincorporation was insignificant, yet many event studies find a significant positive price effect. Moreover, in contrast to his speculation regarding the content of the old and new legal regimes, reincorporating firms perceive the new regime to differ significantly from the old, and the new and old regimes differ on an objective measure of responsiveness as well, with the higher ranked (more innovative) states obtaining the
} 
instance, offer any plausible alternative when he raises his "bundling" critique. In particular, he offers no empirical support for predicting that a federal corporation code would contain fewer harmful provisions than state codes do. There is, in fact, no ground for believing that the political process producing corporate law at the federal level will differ for the better from that in the states. ${ }^{299}$

Other approaches to ascertaining the impact of the legal regime on investor welfare besides stock price studies have been undertaken. Three studies have examined whether firm performance improves upon a change in domicile, using accounting measures of performance (return on equity and earnings before interest and taxes). ${ }^{300}$ The studies find no significant difference in accounting performance for the reincorporating firms. ${ }^{301}$ The absence of significant differences in accounting performance, despite the findings of some of the stock price studies of a significant positive effect, can be interpreted as suggesting that the charter market is in equilibrium, in that firms are selecting the domicile most suited to optimizing their future performance.

Finally, an alternative approach that has been employed to investigate whether competition benefits shareholders is to compare the value of firms incorporated in Delaware, the state that has been the most successful competitor, to the value of firms incorporated in other states. ${ }^{302}$ The idea is that a significant difference for otherwise similar firms would represent the effect of the Delaware legal regime on firm value. Robert Daines undertook such a test, using as his measure of value Tobin's Q, which is the ratio of a firm's market to asset value and thus is a measure of a firm's intangible assets. The ratio is conventionally interpreted by economists as a proxy for a firm's investment or growth opportunities, and Daines' insight is to note that this

most reincorporations, see Romano, supra note 21 at 258-261, 246.

${ }^{299}$ An examination of the lobbying process in the corporate takeover context, commonly viewed as the most problematic area in state codes, indicates that the federal and state political processes (with the exception of Delaware, whose takeover law is more favorable to shareholders than that of other states) are in essentials indistinguishable. See Roberta Romano, The Future of Hostile Takeovers: Legislation and Public Opinion, 57 U. Cin. L. Rev. 457, 468-85 (1988); and infra Part IV.D.

${ }^{300}$ Barry Baysinger \& Henry N. Butler, The Role of Corporate Law in the Theory of the Firm, 28 J.L. \& Econ. 179 (1985) (comparing performance of firms reincorporating in Delaware to firms incorporated in states deemed to have stricter codes than Delaware); Roberta Romano, Corporate Law and Corporate Governance, 5 Indus. \& Corp. Change 277 (1996) (examining change in performance of reincorporating firms over three years following domicile switch, adjusted for industry average performance and also compared to a paired sample of non-reincorporating firms not incorporated in Delaware), Wang, supra note 279 (examining change in earnings before income and taxes adjusted for industry performance, before and after reincorporation, and comparing Delaware and non-Delaware reincorporations). There are far fewer performance studies than event studies for good reason. Economists consider stock price data more reliable than accounting data because investors are interested in future cash flows (that is what stock prices reflect) and accounting data not only measure past cash flows but also provide very imperfect measures of those flows.

${ }^{301}$ Wang finds that the change in earnings over the year after the domicile change is higher for the firms that reincorporated in Delaware, compared to the firms that reincorporated in other states. Wang, supra note 279 , at 23. This is a very interesting finding, but it does not indicate whether the difference is due to Delaware or to the quality of the firms selecting Delaware. 
should include opportunities added by corporate law rules. ${ }^{303}$ Daines finds that Delaware firms have significantly higher Tobin's Q values than non-Delaware firms, controlling for investment opportunities and a set of other variables known to effect Tobin's Q, such as a firm's business diversification, in order to ensure that he is picking up a legal regime effect. ${ }^{304}$

Daine's finding is important because it uses a completely different methodology from event studies and yet has the same key result as those studies regarding state competition, namely, that on average, it benefits shareholders. The fact that different methodologies produce similar results regarding the efficacy of competition renders it difficult for critics of charter competition to dismiss the empirical research that is at odds with their belief that competition and the Delaware legal regime in particular do not benefit shareholders.

These studies also refute James Cox's and Hal Scott's opposition to regulatory competition in securities law on the grounds that investors will not differentiate securities disclosure regimes and discount stock prices accordingly. ${ }^{305}$ This is because the positive price effects of reincorporations and the higher Tobin's Q values of Delaware firms indicate that legal regimes are, indeed, priced by investors. Further evidence refuting this claim is

${ }^{302}$ Daines, supra note 143.

${ }^{303}$ Id . at 10.

${ }^{304}$ This result holds up under a variety of robustness checks that Daines undertakes. For a sense of the economic significance of his results, consider his 1996 finding that Delaware firms' Tobin's Q value is .07 higher than non-Delaware firms; this translates into a 5\% higher market value for Delaware firms than non-Delaware firms. Id. at 13. Daines offers two explanations of how Delaware corporate law would add value to firms: facilitation of takeovers and superior protection of public investors from exploitation by insiders, compared to other state regimes. Id. at 17. For evaluating the efficacy of state competition, ascertaining the precise reason for Daines' result that Delaware's legal regime enhances share value is not of strict importance; only determining whether it increases or decreases firm value is. But Daines' thesis regarding facilitation of takeovers is consistent with the investor-disappointment interpretation of Heron and Lewellen's finding concerning firms reincorporating for defensive tactics advanced in supra note 295. When considered in conjunction with Daines' finding, Wang's finding of a greater performance improvement for Delaware than non-Delaware reincorporations, see supra note 301, can also be interpreted as evidence that the Delaware legal regime improves firm value.

${ }^{305}$ Cox, supra note 3, at 1233-36; Hal S. Scott, Internationalization of Primary Public Securities Markets, 63 Law \& Contemp. Probs. 71, 75 (2000). Scott asserts in particular that investors "sophisticated or otherwise" cannot know what information they are "missing" and thus cannot discount securities properly. Id. This contention is plainly incorrect. First, investors know what fundamental financial information is and can clearly tell whether a firm's financial statements contain the information of importance to them. This is evidenced by the fact that firms respond to their demands to disclose information that is not required, as discussed in supra Part III.C.4. Second, investors are able to compare the differences in disclosures required by competing regimes and are thus able to discount the securities of issuers registered under regimes that require less disclosure where the omitted information is valued by the investors. The data, discussed in this section, on state competition and bond covenants provide compelling support for this proposition. Third, Scott does not offer any reason for why in the case of what he terms "missing" information - that is, some item that no firm discloses so no one knows the information is "missing" from firms - a government agency would know what sophisticated investors do not know, that an important piece of information is missing, and mandate its disclosure so that the market can price it. Of course, when the ostensible missing disclosure concerns information about one firm that is disclosed by others, sophisticated investors and financial analysts will notice the omission and discount the stock, treating silence adversely, which could prompt disclosure by the firm to 
that bond investors price differences in indenture covenants: bonds with call protection and with event risk protection, for instance, have lower interest rates than those without such protections. ${ }^{306}$

Critics of charter competition have contended that the findings by Daines and the event study literature do not demonstrate that state competition benefits shareholders, but, rather, are evidence that the victor of the competition is simply somewhat better than the rest of what is, in essence, a rotten bunch and that the value of firms would be even higher under a regime of less competition that implements the legal rules the critics prefer to those produced by competition. ${ }^{307}$ However, it should be noted that if, as some of the critics of charter competition acknowledge, the most successful competitor increases shareholder wealth, then it is not possible for them to contend that competition is a "race to the bottom": if competition were a race to the bottom, then shareholders should fare the worst, not the best, under the most successful competitor's regime. The confident assertion, without any empirical support, that the value of firms would be higher were substantive corporate law rules the ones espoused by a commentator, rather than the ones produced by competition, is not an answer to the research findings that Delaware law and, hence, competition for charters have provided shareholders with economic benefits. ${ }^{308}$

\section{B. Do U.S. States Compete for Charters?}

Some commentators have contended that because of Delaware's dominant position in the charter market, one cannot view the production of corporate laws in the United States as a competitive market. ${ }^{309}$ Their position is that other states do not even attempt to compete with Delaware for incorporations. This contention has often been made in conjunction with the use of network economics to explain Delaware's success, that there are economies of scale in the choice of a legal regime-for example, the stock of legal precedents—-that cannot be

reduce the discount. See supra notes 76-78 and accompanying text.

${ }^{306}$ See, e.g., Robert E. Chatfield \& R. Charles Moyer, "Putting" Away Bond Risk: An Empirical Examination of the Value of the Put Option on Bonds, 15 Fin. Mgmt. 26, 31-32 (1986); Leland Crabbe, Event Risk: An Analysis of Losses to Bondholders and "Super Poison Put" Bond Covenants, 46 J. Fin. 689, 690 (1991); Richard J.

Kish \& Miles Livingston, Estimating the Value of Call Options on Corporate Bonds, 6 J. Applied Corp. Fin. 95, 97 (1993).

${ }^{307}$ See, e.g., Lucian Bebchuk \& Allen Ferrell, A New Approach to Takeover Law and Regulatory Competition, 87 Va. L. Rev. 111, 138-139 (2001).

${ }^{308}$ There are, in fact, no data indicating that the particular law that Bebchuk and Ferrell prefer to Delaware's regime, the takeover code promulgated by the City of London's Panel on Takeovers and Mergers, see Bebchuk \& Ferrell, supra note 180, has made U.K. firms more valuable than Delaware firms.

${ }^{309}$ E.g., Marcel Kahan \& Ehud Kamar, Price Dis crimination in the Market for Corporate Law 12 (New York Univ. Ctr. for Law \& Bus. Research Paper No. 00-011, 2000), available at SSRN Electronic Paper Collection, http://papers.ssrn.com/paper.taf?abstract_id=217849; Mark J. Loewenstein, Delaware as Demon: Twenty-five Years After Professor Cary's Polemic, 71 U. Colo. L. Rev. 497 (2000). 
successfully duplicated by other states and thereby place Delaware in the position of a monopolist. ${ }^{310}$ This does not contradict the evidence of positive price effects of a Delaware domicile. Rather, it makes those data all the more puzzling, because they would indicate that Delaware is not extracting all the possible monopoly rents from domestic corporations.

Marcel Kahan and Ehud Kamar, who are skeptical that charter competition exists, have maintained that states do not compete for charters because they have not attempted to duplicate what makes Delaware the preeminent incorporation state: a specialized court and its higher franchise fee structure, which leads to its dependence on franchise tax revenues. ${ }^{311}$ Other states cannot, however, duplicate Delaware's higher franchise fee structure in order to compete for a share of local charters. Because Delaware offers a superior product (a substantial stock of legal precedents, expert judiciary and administrative services, and a commitment to continued statutory responsiveness), ${ }^{312}$ for another state to compete, it has to charge a lower, not higher, price for its

${ }^{310}$ E.g., Ehud Kamar, A Regulatory Competition Theory of Indeterminacy in Corporate Law, 98 Colum. L. Rev. 1908 (1998); Michael Klausner, Corporations, Corporate Law and Networks of Contracts, 81 Va. L. Rev. 757 (1993). James Cox does not question whether states compete for charters, but, instead, contends that the states did not compete with the SEC over securities disclosure regulation in their Blue Sky laws and that the experience in the Blue Sky market, which he considers to have been a "race to the bottom," rather than the experience in the corporate charter market, is the appropriate context from which to predict the output of securities regulatory competition. Cox, supra note 3, at 1243-44. In a more recent article, Cox restates the claim: he contends that because the states did not "impose demanding disclosure requirements," but, rather, have deferred to the federal agency over the past several decades while they have operated securities regimes alongside the SEC's mandatory regime, they will not impose stringent disclosure requirements under regulatory competition. James D. Cox, Premises for Reforming the Regulation of Securities Offerings: An Essay, 63 Law \& Contemp. Probs. 11, 34 (2000). Cox's contention is, however, mistaken. The experience under state securities law is not probative for regulatory competition because the jurisdictional rule, securities sale location, prevents states from competing: a state does not exe rcise exclusive authority over an issuer, but, rather, shares regulatory power with all sovereigns in which its shares are sold, and hence the states have no incentive to fashion alternative disclosure regimes that would be of value to investors. Cox further claims that "nearly every decision" of the SEC in the "past two decades" has been related to competition. Id. at 35. This claim is misplaced: the competition and decisions to which he refers have no connection to U.S. issuer disclosure regulation or antifraud liability, but, rather, have to do with trading systems and foreign issuers or securities of U.S. issuers that are not publicly traded, and even here, the reduction in disclosure requirements for foreign issuers is not as substantial as Cox suggests. As I discussed in my prior article, Romano supra note 2, at 2397-98, and consistent with the theory of regulatory competition, the SEC has been responsive where it has encountered competition from foreign regulators or other federal regulators such as the Commodity Futures Trading Commission. Over the last two decades, it has not, however, altered its disclosure regulations for U.S. issuers of public equity, except to increase the mandated items, an excellent example of which is the new derivatives' risk disclosure rules cited in supra note 151. The move to integrated disclosure, which Cox cites in support of his claim about the SEC's behavior, to the contrary did not decrease the disclosure requirements for U.S. issuers -it only shifted the filing focus from the 1933 Act to the 1934 Act. Finally, the SEC has consistently increased, not decreased, liability for violations of the federal securities laws; a good example is its adoption of a rule against insider trading in the context of a takeover, which makes it easier to find non-conventional insiders liable than is possible under the Supreme Court's jurisprudence. Rule 14e-3, 17 C.F.R. § 240.14e-3 (2001).

${ }^{311}$ Kahan \& Kamar, supra note 309.

${ }^{312}$ See, e.g., Romano, supra note 22, at 38-41 
product, to be able to attract a sufficient number of firms to build up the legal capital that Delaware already possesses.

States, in fact, can and do compete with Delaware for incorporations, even though they have mot undertaken the expense of replicating its most valuable assets, which would be a high-risk undertaking because the state might expend considerable resources but still not unseat Delaware. States engage instead in behavior that can be termed "defensive" competition, in that they seek to discourage local firms from reincorporating in Delaware, rather than seeking affirmatively to attract firms away from Delaware. ${ }^{313}$ There is considerable evidence of such competitive behavior.

First, Delaware is not the only state to be continually revising its corporation code: other states invariably follow suit, revising their codes to follow Delaware's innovations, and at least one commentator has characterized recent revisions to the Model Business Corporation Act ("MBCA") ${ }^{314}$ as evidence supporting the view that states tend to compete for charters because the revisions bring the MBCA, which many state codes follow, closer to the law of Delaware. ${ }^{315}$ After revising their codes, the states then publicize their legislative reform efforts as a reason to retain an in-state domicile rather than incorporate in Delaware. ${ }^{316}$ If the states were indifferent to the retention of local corporations as domestic incorporations, then they would have no reason to engage in such activity. Second, although Nevada has never seriously challenged Delaware as the leading reincorporation state, it did expressly set out to be the "Delaware of the West" and was one of the few states to achieve a higher inflow than outflow of migrating firms. ${ }^{317}$ Finally, if competition from other states were not a threat, Delaware would have no reason to update its code as attentively as it does. ${ }^{318}$ Indeed, Delaware's continued responsiveness to changing

${ }^{313}$ Romano, supra note 21, at 236.

${ }^{314}$ Model Bus. Corp. Act Ann. (3d ed. 1996).

${ }^{315}$ Lawrence A. Cunningham, The New Corporate Law-The 1999 Model Business Corporation Act, 71 Corp. (Aspen L. \& Bus.) 1, 5 (2000).

${ }^{316}$ See, e.g., James I. Lotstein \& Christopher Calio, Why Choose Connecticut? Advantages of the Connecticut Business Corporation Act Over the Delaware General Corporation Law, 10 Conn. Law. 10 (2000) (article noting recent code updates in 1997 and 1999 following Model Act and pointing out consequent advantages of Connecticut incorporation over Delaware, such as use of explicit statutory guidance rather than case-law interpretation for indemnification, derivative suits, and conflicting interest transactions and use of more flexible default rules, including treatment of legal capital).

${ }^{317}$ Nevada and Virginia were the only two states besides Delaware that had a net inflow of reincorporating firms in my study of reincorporations, Romano, supra note 21, at 247 (figure 3).

${ }^{318}$ One might contend instead that Delaware's attentive updating of its code is simply innovation undertaken by a monopolist and not by a firm concerned about competition. However, economic theory is ambiguous concerning whether monopolists innovate more than firms in a competitive industry. Monopolists tend to innovate more slowly than competitive firms when there is only one innovator, and thus there is no patent race; but in the context of a patent race, both monopolists and competitive firms innovate more rapidly than they otherwise would, and a monopolist could have stronger incentives to innovate (and preempt a patent race), as it would obtain a higher return from preempting entry than a firm in a competitive market. See Dennis W. Carlton \& Jeffrey M. Perloff, Modern 
business needs through statutory innovation, despite its commanding lead in the incorporation market, rebuts a criticism of regulatory competition in securities law offered by Donald Langevoort, that whichever state wins the "competition early on" will thereafter behave as a monopolist "threatening the benefits that would otherwise flow from true competition." 319

Further suggestive evidence that states compete with Delaware to retain local firms, in accord with the anecdotes concerning states publicizing their corporation code updating, is the finding that the diffusion of corporate law reforms across the states follows an ogive or S-shaped cumulative distribution (the proportion of adopters increases over time). ${ }^{320}$ This pattern is conventionally interpreted in the industrial organization literature on product innovation to be an indication of robust competition. ${ }^{321}$ A recent study examining the pattern of diffusion of new financial products across banks (a pattern in which the adoptions increased over time in a distribution resembling the ogive pattern of corporation code innovations) determines that the diffusion pattern is explained by competitive ("bandwagon") pressure on non-adopters to maintain customer relations and market share, rather than other explanations involving product profitability or information externalities. ${ }^{322}$ Adoption of innovations due to competitive bandwagon effects is, in fact, considered to be more likely when there are significant first-mover advantages and small adoption costs, ${ }^{323}$ factors entirely consistent with the defensive competition that occurs in the corporate law context.

In addition, there is a positive relation between revenues collected from incorporation (franchise) taxes and a state's responsiveness to corporations' legislative demands (a composite variable measuring whether and how rapidly a state adopts corporate law innovations mentioned by a survey of domicile-switching firms as important in their decisions), an effect that persists when Delaware is excluded from the statistical analysis. ${ }^{324}$ This relationship is consistent with what I have termed a "hostage" theory of the charter market and Delaware's

Industrial Organization 534, 541 ( $3 \mathrm{~d}$ ed. 2000). However, as corporate law is not patentable, the patent race analogy is not necessarily apt. The modeling of innovation in a nonpatentable context, such as innovation in financial products rather than industrial (technological) products, is less advanced. Of two models that have sought to bridge this gap, one model with positive externalities (economies of scale that are a function of more consumers of the product and create profit opportunities analogous to patents for the banks) results in inconclusive equilibria regarding whether more, if any, innovation occurs with a monopolist or competition, while the other model shows that a lack of patent protection may in fact increase innovation and not induce free-rider problems in a competitive industry. See Philip Molyneux \& Nidal Shamroukh, Financial Innovation 195-201 (1999). In fact, the latter model would seem to approximate what has occurred in the banking sector: there has been significant financial product innovation despite (if not because of) the competitiveness of the industry. Id. at 47-48.

${ }^{319}$ Donald C. Langevoort, Deconstructing Section 11: Public Offering Liability in a Continuous Disclosure Environment, 63 Law \& Contemp. Probs. 45, 50 (2000).

${ }^{320}$ Romano, supra note 21, at 233-35; Carney, supra note 27, at 731-32.

${ }^{321}$ Romano, supra note 21, at 235.

${ }^{322}$ Molyneux \& Shamroukh, supra note 318, at 11, 262-63.

${ }^{323} \mathrm{Id}$. at 212 . 
success, in which the more heavily a state relies on incorporation revenue, the more responsive it will be to corporate needs and hence the more attractive a domicile for firms. The fact that the positive relation is present even excluding Delaware from the analysis is important additional data suggesting that states are competing for domestic incorporations.

Kahan and Kamar maintain that the continual updating of corporation codes by states other than Delaware is not evidence of states engaging in competition, but their provision of a "service" to citizens. This characterization of the motive for code updating does not demonstrate that states do not compete. This is because states do not have to provide such a service: their citizens can use Delaware's code or that of another state and do business as a foreign corporation. We have to ask why the state would want to provide such a service: the only plausible answer is that it wants domestic corporations. Once this is acknowledged, no matter what euphemism is used to describe the motivation for code updating activity, it is an indication that states are competing for local charters. The dominant interest group behind the desire to revise codes in order to have local charters may well be the local corporate bar, rather than the state treasurer's office, but this is standard operating procedure: in all states, including Delaware, the corporate bar is, in fact, the engine of statutory reform. To be sure, Delaware state officials, and not just the corporate bar, pay close attention to their incorporation business. But other states' officials' attention need not be as focused for a state to engage in successful defensive charter competition; they can rely on the local bar to notify them if legislative action is necessary to maintain that position, just as members of Congress depend on constituents to inform them of problems in an agency's administration rather than actively monitor the agency themselves. 325 There is also still a financial incentive for the state to compete: the income of the local corporate bar and a state's franchise revenues are, in all likelihood, positively correlated. ${ }^{326}$ In sum, to the extent that states are affirmatively providing the service of domestic incorporation, they are doing so to facilitate local incorporation (which aids the local bar) and thereby to discourage foreign incorporation and transfers of domicile affiliation (i.e., they are defensively competing for local charters).

Kahan and Kamar also discount the positive relation between franchise revenue and corporate law responsiveness as evidence of state competition because total franchise tax revenues, rather than the marginal

${ }^{324}$ Romano, supra note 21, at 236-41.

${ }^{325}$ See Mathew McCubbins \& Thomas Schwartz, Congressional Oversight Overlooked: Police Patrols Versus Fire Alarms, 2 Amer. J. Pol. Sci. 165 (1984) (contrasting fire alarm and police patrol forms of congressional oversight of the executive branch).

${ }^{326}$ Moreover, there is a direct fiscal payoff to a state for responding to demands of the bar to update its corporation code and not just an indirect benefit of the local bar's higher income tax revenues from servicing domestic corporations: the positive relation between franchise revenues and corporate law responsiveness holds up for all states and not simply for Delaware. See supra note 324 and accompanying text. 
revenue a state receives from incorporations, is used in the analysis. ${ }^{327}$ They have a point. Total franchise tax revenue is a less precise measure of states' incentives than marginal incorporation revenue under the standard economic principle that marginalism drives behavior. However, marginal incorporation revenue is unfortunately a number that is impossible to calculate accurately given the form in which data on state tax revenues are made available. Hence total franchise revenues will have to suffice, as they are the best data to be had.

But the use of total rather than marginal revenue in relation to corporate law responsiveness as a test for the presence of competition is not the fatal difficulty that Kahan and Kamar's objection might appear to suggest. Because firms have the freedom to choose their incorporation state, it is plausible that there is a positive correlation between marginal and total revenue. Indeed, if there were no correlation between total and marginal revenue, there should not be the positive relation between total franchise revenue and corporate law responsiveness that the data identify. This is because the most plausible explanation for the empirical finding relating responsiveness and total revenue is that marginalism is at work, that is, that states are competing for charters. Kahan and Kamar do not advance an alternative explanation of the finding. Their explanation that states revise corporation codes as a service to citizens, for example, would not predict a systematic positive relation between total franchise revenue and responsiveness, because states that are not competing for charters provide the service regardless of the number of local firms and, hence, regardless of the revenue received from incorporations. If they were correct, there should be no relation between the variables. In addition, although they do not articulate their critique in this fashion, Kahan and Kamar may be concerned that total revenue includes foreign firms' taxes and that firms' presence in a state other than Delaware may be inelastic (that is, the state collects franchise fees from all firms doing business in the state). ${ }^{328}$ But if this is their concern, then again, we should expect to find no statistical relation between total revenue and responsiveness because states do not provide any service to foreign incorporations: they are covered by another state's code. However, the data are otherwise- the relation is significantly positive.

\section{Network Externalities and Corporate and Securities Law}

Some commentators have used network economics to analyze state competition. In this view, Delaware is successful in the corporate charter market because there are network externalities in corporate law, that is, there are economies of scale and scope that depend on a product's (here a state corporation code's) adoption by large numbers of users, such as the production of legal precedent. This phenomenon enables Delaware to maintain a

${ }^{327}$ Kahan \& Kamar, supra note 309, at 26 n.51.

${ }^{328}$ Because virtually all Delaware firms have no physical presence in Delaware, such a concern is not relevant with respect to Delaware and there is a nearly perfect positive correlation between its total and marginal 
monopoly position, as rival states starting from a smaller base of corporations will not be able to achieve the same cost economies.

Proponents of the network approach have advanced two arguments to critique the efficacy of the corporate laws produced by state competition. These consist of the claim that the legal rules produced by state competition are sub-optimal because of a lock-in effect in which it is too costly for firms to shift from an inefficient to a more efficient legal network ${ }^{329}$ and the claim that to maintain its monopoly power, which is derived from network externalities, Delaware purposefully crafts its legal rules to be excessively uncertain and unpredictable. ${ }^{330}$ While theoretically possible, neither of these claims stands up to scrutiny.

\section{Will Corporation Codes or Securities Regulation Exhibit Inefficient Lock-in Effects?}

Proponents of the network approach to corporate law suggest that a potential consequence of a successful chartering business such as Delaware's, in which the more domestically incorporated firms there are, the higher the value to firms of operating under the regime, is that inefficient corporate law provisions will be locked-in (that is, the network effect creates an externality in which new firms are better off joining the existing network with inefficient provisions rather than incorporating in a new network with few firms but a superior code). ${ }^{331}$ However, as an analytical matter, as S.J. Leibowitz and Stephen Margolis have suggested, network effects are not necessarily externalities: they are only a problem such that an inefficient network will not be replaced by a more efficient one when market participants cannot internalize the effects. ${ }^{332}$ Thus, if a dominant network is inefficient compared to a competing one, the owner of the more efficient one will internalize the costs of the network, and with a more efficient product, it will be able to subsidize switchers. ${ }^{333}$

franchise fee revenues.

${ }^{329}$ Klausner, supra note 310, at 850-51.

${ }^{330}$ Kamar, supra note 310; Kahan \& Kamar, supra note 309. Kamar further applies the theory of network externalities to contend that competition is not appropriate for securities regulation. Kamar, supra note 310, at 195051.

${ }^{331}$ Klausner, supra note 310, at 850-51.

${ }^{332}$ See Leibowitz \& Margolis, supra note 24, at 671; Stan J. Leibowitz \& Stephen E. Margolis, Network Externality: An Uncommon Tragedy, 8 J. Econ. Persp. 133, 141-42 (1994).

${ }^{333}$ Michael Klausner has suggested that the lock-in of an inefficient provision in corporate law would not be due to information imperfections (that the first firms adopting charters do not recognize that their choice of provisions is inefficient), but due to an externality between early and later users of a product (the benefits of participating in the larger existing network despite its inefficient rules). Michael Klausner, A Comment on Contract and Jurisdictional Competition, in The Fall and Rise of Freedom of Contract 349, 451 n.15 (Frank H. Buckley ed., 1999). Hence this source of network inefficiencies is the focus of the discussion in the text, although it should be noted that the two effects are closely related. A lock-in of inefficient corporate laws because early adopters lacked information regarding the optimal provision would not be a sustainable charter market equilibrium over time. There are well-informed specialists - lawyers and investment bankers - who are repeat players because they advise numerous firms and who will therefore internalize the cost of becoming informed regarding an inefficient choice, in 
While an individual corporation cannot internalize the cost of a charter regime, corporate law regimes have owners that can do so: the legislating states. If, for example, the Delaware state courts take actions that significantly decrease share values or if the Delaware corporation code is not revised to address a developing corporate law issue that another state code has remedied, Delaware's franchise tax revenues will decrease as the flow of firms into the state will decrease (at some point, the cost of the inefficient regime will outweigh the network benefit of the stock of precedents because the stock will not address the new issue rendering Delaware law inefficient or outdated). The state will therefore bear the cost of the inefficient regime. In addition, Delaware counsel, whose business it is to be informed about corporate law matters and whose human capital will diminish with a decline in Delaware incorporations, are organized in a state bar association that eliminates free-rider problems and thereby ensures that the legislature will ameliorate the problem.

The contention that Delaware internalizes network externalities that would otherwise produce inefficient rules is not mere speculation: after a decision by the Delaware Supreme Court that was considered to be adverse to shareholder welfare because it increased the financial liability of outside directors at a time of an unstable liability insurance market, legislation was enacted to negate the impact of the decision by permitting shareholders to vote to limit outside directors' liability. ${ }^{334}$ Other states had also been moving toward legislative reform of director liability, further spurring Delaware's action. ${ }^{335}$

Additional support for the proposition that a dominant legal network will be supplanted by another set of rules if they are more efficient is a study of Australian corporate law by Michael Whincop. ${ }^{336}$ Whincop examined corporate charter terms regarding fiduciary duty (the mix of indemnification and liability release provisions) prior to the enactment of mandatory government terms in the late 1920s, classifying common clusters of terms into three "networks." 337 He then tracked the use of these clusters or networks (their "market share") over time, taking account of switches by charter amendment. Whincop found that a new mix of indemnification and release

contrast to individual corporations, and as a result, either they will ensure that the incorporation state revises the inefficient provision or have their individual corporate clients switch to the more efficient regime.

${ }^{334}$ See Roberta Romano, Corporate Governance in the Aftermath of the Insurance Crisis, 39 Emory L.J. $1155,1160(1990)$

${ }^{335}$ Id.

${ }^{336}$ Michael J. Whincop, Emp irical Analysis of Corporate Charters and Mandatory Rules: An Australian Study (2000) (unpublished manuscript).

337 The separate networks he identifies are: (1) low-level indemnity provisions with releases of personal liability subject to a dishonesty qualification (the largest network at $46 \%$ of the sample); (2) wide indemnification and narrower releases, both qualified by willful default exceptions; and (3) limited releases and no or restricted indemnities (the statutory default requirement). The remaining firms that did not fit into one of these three groupings ( $30 \%$ of the sample) are classified into a fourth, miscellaneous category. The first group was not initially the most popular group, but emerged as the dominant choice, replacing the other clusters, by the time the government enacted mandatory rules and ended the era of charter experimentation on fiduciary obligations. 
terms emerged and came to predominate, despite the existence of a substantial older network. This finding is consistent with the proposition that network effects of inefficient corporate law provisions (or provisions that lose their efficient properties as business conditions change) will not prevent the emergence of, and switch to, more efficient provisions. Whincop's research parallels what casual empiricism would suggest regarding U.S. corporation codes: Delaware is constantly revising its code as business conditions change, despite its large stock of precedents that should, under a network externality analysis, prevent it from updating to more efficient provisions. These phenomena (the Australian contracting experience and Delaware's attentive code updating) suggest that early charter provision users will not impose significant externalities on subsequent users that result in the persistence of inefficient corporate charter provisions.

A further difficulty with the lock-in argument concerns whether competing corporate law networks offer truly incompatible products (the reason why a larger market share produces a lock-in effect). The MBCA can be understood as a competing network to Delaware law as it enables adopting states to share in the precedents of all users of MBCA boilerplate, as well as the resources of the Model Act's drafting committee. However, many of the MBCA provisions are similar to those of Delaware, and consequently, state courts can, and often do, borrow from Delaware precedents, whether or not they are MBCA adopters. ${ }^{338}$ These factors place a limit on the size advantage of Delaware's network and no doubt explain why it is continually updating its code (it is concerned about competition, which would not be the case if its size advantage were unlimited).

Additional criticisms of the significance of possible network effects involve the key assumption for there to be a network effect of increasing returns to scale. To the extent that production costs exhibit decreasing returns or that the increasing returns to a network eventually diminish, then competing networks are possible (and presumably persistence of inefficient networks unlikely). ${ }^{339}$ It is altogether possible that production of a legal regime manifests diminishing returns: one instance of such an effect is court docket congestion. Furthermore, if different rules are appropriate for different firms, then competing networks can develop to serve niche markets where size (network effects) is not a disadvantage. ${ }^{340}$ Although niche-filling does not seem to be a significant factor in corporate law as there is not a substantial variety in state codes, it may be more important in securities law (if, for instance, different financial accounting standards were appropriate for different sectors or market environments).

It should be noted that in the securities law context, in addition to state actors, there is a further set of

${ }^{338}$ See Cunningham, supra note 315; Lotstein \& Calio, supra note 316. A recent example of a court analyzing a state code by reference to Delaware law is Hilton Hotels Corp. v. ITT Corp., 978 F. Supp. 1342 (D. Nev. 1997) (Nevada law).

${ }^{339}$ See Leibowitz \& Margolis, supra note 24, at 672-73.

${ }^{340} \mathrm{Id}$. at 673. 
private actors-stock exchanges, which could internalize network externalities regarding aspects of the regime, such as disclosure requirements, if such rules were in their jurisdiction, as occurred prior to the creation of the SEC. This could occur with competition if a small jurisdiction were to choose a securities regime that delegates disclosure standards for listed firms to exchanges. ${ }^{341}$ Stock exchanges control which firms list on their exchanges, and thus they can internalize any potential network externalities that would cause the maintenance of inefficient rules. ${ }^{342}$ Because firms pay annual listing fees, an exchange that devises a superior set of rules can subsidize firms to switch from another network.

Of course, for an individual firm, the number of other listed firms is not important; it only cares about the trading location that gives it the lowest cost of capital. But investors may prefer exchanges with numerous listings in order to obtain the benefit of standardization in disclosure when exchanges are the source of such standards, and their preferences will feed back into firms' choice of exchange. However, it must also be noted that standardization is not of itself evidence of network effects. One standard may prevail over another because it is better adapted to investor needs. ${ }^{343}$ Finally, as already noted, if the appropriate disclosure standard varies across firms or investor clienteles, then network effects will not be important, as small specialty networks will flourish alongside larger networks.

A separate issue that might be considered to distinguish securities and corporate law that could be subject to network effects involves enforcement. The issue is whether policing violations in the securities context requires substantial government action, in contrast to corporate law, where violations are policed by private litigation. If this were the case, economies of scale in enforcement operations (that is, network effects) could limit competition, as small states could lack the requisite resources to police securities violations. The enforcement issue is not, however, a clear-cut case of a network externality. There could well be increasing production costs (decreasing returns to scale) in government enforcement activities. The SEC, for example, relies heavily on private litigation for enforcement support. Whether the SEC delegates enforcement activities to private parties because of limited resources or because of increasing production costs, smaller states could also rely on private enforcement to compensate for scale disadvantages, if the revenues produced by their securities business are insufficient to cover enforcement costs. A need for a minimum state size for enforcement purposes is therefore not likely to create a substantial barrier to the effectiveness of regulatory competition in the securities

${ }^{341}$ See Romano, supra note 2 , at 2401.

${ }^{342}$ Some important exchange services that have a network effect are fully priced: the provision of liquidity is borne by market participants in the form of the bid-ask spread (expected asset returns are an increasing function of the bid-ask spread). See, e.g., Yakov Amihud \& Haim Mendelson, Asset Pricing and the Bid-Ask Spread, 17 J. Fin. Econ. 223 (1986).

${ }^{343}$ See Leibowitz \& Margolis, supra note 24, at 673. 
law context.

There could still be a problem with respect to enforcement that unscrupulous promoters will exploit investors by choosing a jurisdiction with inadequate enforcement capacity. Resources for enforcement operations do not constitute a problem for large sovereigns or small sovereigns that, by offering a superior regime, earn a significant financial return from domicile fees (as Delaware does from incorporation fees). As these jurisdictions would also, in all likelihood, be the domicile choice of most publicly-traded firms, whose clientele includes sophisticated investors cognizant of enforcement issues, the enforcement-capacity problem is analogous to the earlier discussed problem of segmented markets regarding substantive regime content and not to a network effects problem. Prodding unsophisticated individuals to invest through financial intermediaries would, again, be the most effective solution to any potential enforcement concern. ${ }^{344}$

\section{Is Delaware Law Excessively Indeterminate?}

The second claim made by commentators using network economics to critique the output of state competition asserts that Delaware's legal regime is "excessively" unpredictable or indeterminate, compared to what it "could be." This claim is associated with Ehud Kamar. ${ }^{345}$ The hypothesized motivation for having indeterminate legal rules is to prevent other states from successfully copying Delaware law and thus decreasing the monopoly position Delaware has achieved because of network externalities regarding legal precedents. ${ }^{346}$ The evidence Kamar adduces for this claim is the "court-centered" culture of Delaware corporate law and Delaware's use of "fact-intensive standard-based tests," which are not always used in other states or SEC regulation. ${ }^{347}$

The initial difficulty with the contention that Delaware law is excessively fact-intensive is one of first principle: that the claim is founded upon a misunderstanding of the common law process. Objecting to the factintensive nature of Delaware law misses the essence of judicial adjudication at common law (or, to put it another way, it is an objection to common law adjudication itself). Common law decision-making is, by definition, factintensive, because it entails an inductive approach to decision-making that creates general rules out of the resolution of specific disputes in incremental fashion. Moreover, the principal reason for judicial intervention in corporate law is to enforce fiduciary obligations that, by their very nature, cannot be well-specified in a contract - otherwise they would be written into the corporate statutes and documents. The judicial inquiry into these issues is, therefore, inherently fact-based. ${ }^{348}$ And, of course, their resolution must be undertaken by courts

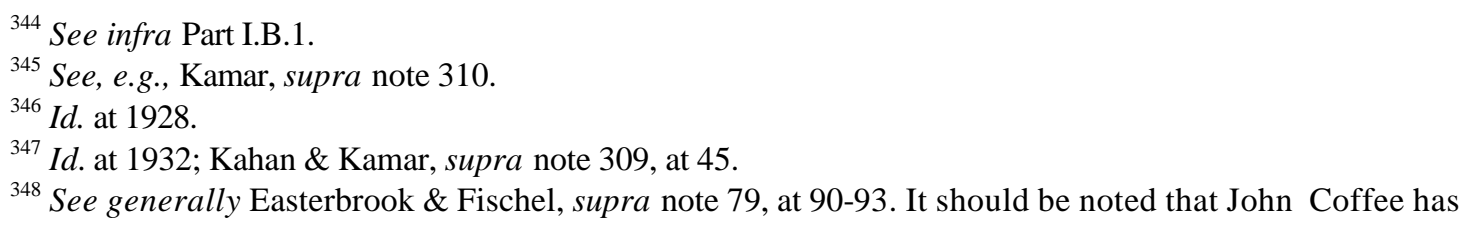


and not legislatures, which are ill-suited to engage in case-by-case decision-making.

The second difficulty with the line of reasoning that Delaware law is excessively indeterminate involves a confusion between the choice of legal rules or standards and the unique position of Delaware compared to other states in the chartering market. In contrast to all other states, Delaware has a specialized judiciary that hears all corporate law cases, the Chancery Court, and corporate law expertise is usually an important selection criterion for state Supreme Court justices. It is, accordingly, a clear-cut benefit to shareholders of Delaware firms to use the judicial process to resolve fiduciary issues, as the parties have access to decision-makers with significant expertise who can tailor a ruling to the specific problems of the claimants.

In other states, recourse to the judiciary does not offer any such benefit to shareholders, because courts of general jurisdiction, with no expertise in corporate law and infrequent exposure to corporate issues, hear corporate cases. Thus, to compensate for their competitive disadvantage, states other than Delaware tend to adopt the defensive strategy of more explicit rules that are intended to reduce the need to resort to the judiciary's judgment in disputes. Indeed, some states attempt to promote this as a marketing advantage for local incorporation, stressing a lower level of reliance on the judiciary with explicit statutes compared to a Delaware domicile. ${ }^{349}$ Consequently, the fact that states other than Delaware substitute bright-line rules for a standard to determine fiduciary issues is not proof that Delaware law is "excessively indeterminate," but, rather, evidence that they are seeking to make the best of what is a competitive disadvantage of their legal systems. This characterization is consonant with the widely shared perception of practitioners that Delaware courts are superior decision-makers than other state courts when it comes to corporate law matters, as well as efforts by the corporate bars in some states to promote legislation to create specialized corporate law courts. ${ }^{350}$

Kamar further attempts to support his claim that Delaware law is excessively indeterminate by asserting that there is greater clarity in U.S. securities law than Delaware law, citing the existence of safe harbor rules for complying with registration requirements. ${ }^{351}$ This comparison is erroneous. The areas of securities law that are related to substantive corporate law issues, such as insider trading regulation and other forms of antifraud liability under Rule $10-b 5^{352}$ are not, in fact, bright-line rules, but imprecise legal standards. Not only is the language of

suggested that Delaware's fact-based judicial process may seem "inherently indeterminate" to Kamar because his "initial legal training was in the civil law" in Israel and not the common law. Coffee, Jr. et al., supra note 270 , at 89 n.16 (remarks of John C. Coffee, Jr.).

${ }^{349}$ See Lotstein \& Calio, supra note 316, at 10 ("[T]he [Connecticut Business Corporation Act] contains more explicit guidance to corporations and their lawyers than the [Delaware General Corporation Law] which relies heavily on case law to interpret the statute.").

${ }^{350}$ See, e.g., Thomas A. Slowey, Pennsylvania Chancery Court Is a Sound Proposal, Pa. L. Weekly, May 2, 1994, at 6.

${ }^{351}$ Kamar, supra note 310, at 1920.

${ }^{352}$ E.g., Securities Exchange Act of 1934, $\S \S 10,16,15$ U.S.C. $\S \S 78 j, 78 p$ (2001); Rule 10b-5, 17 C.F.R. $\S$ 
the antifraud rule more general than any of the Delaware fiduciary standards that Kamar finds wanting, but also, the SEC has opposed enacting a statutory definition of insider trading, a position with which Congress has acquiesced, even though a definition would provide a bright-line rule and eliminate the existing "standards" approach. ${ }^{353}$ Underscoring Kamar's misplaced comparison is one former SEC solicitor's comment that "in sider trading is a classic example of common law in the federal courts."354

A third and, in my judgment, insurmountable difficulty with Kamar's thesis is how one could ever identify where, to use Kamar's language, the "level of indeterminacy of Delaware law may be too high" or where it is "less predictable than it could be." 355 As corporate law practitioners well know, Delaware law is more predictable and certain than that of any other state, and that is one of the principal reasons they prefer to incorporate clients in Delaware. $^{356}$ Indeed, the settlement rate of Delaware cases is not significantly different from that in other states. $^{357}$ This would not be the situation if there were greater uncertainty of outcomes under what Kamar identifies as Delaware's more fact-intensive standard-based law, because risk-averse parties are less likely to litigate and more likely to settle when there is greater uncertainty regarding the legal rule. ${ }^{358}$ To the extent that divergent perceptions of the likelihood of success at trial decrease the likelihood of settlement, a reduction in the uncertainty of predicting the outcome of litigation should increase the settlement rate. ${ }^{359}$ In either scenario, if, as

240.10b-5 (2001).

${ }^{353}$ See, e.g., Larry E. Ribstein \& Peter V. Letsou, Business Associations 994 (3d ed. 1996). Kamar recognizes that elements of antifraud liability under the securities laws are as indeterminate as Delaware law is, Kamar, supra note 310 , at $1952 \mathrm{n} .175$, but misses the implication that the use of a standard is most plausibly integrally connected to the nature of the legal issue to be decided rather than the strategic motivations of adjudicators in relation to chartering revenues.

${ }_{354}^{35}$ Unidentified official quoted in Stephen M. Bainbridge, Securities Law: Insider Trading 29 (1999).

${ }^{355} \mathrm{Kamar}$, supra note 310, at 1913-14 (emphasis added).

${ }^{356}$ See Romano, supra note 21, at 250, 274 (reasons provided by counsel for reincorporating firms). This theme was repeatedly emphasized by corporate counsel attending the University of Pennsylvania Roundtable, referred to in supra note 143, at which the Kahan and Kamar paper was presented.

${ }^{357}$ In my sample of 139 shareholder lawsuits, see Roberta Romano, The Shareholder Suit: Litigation without Foundation?, 7 J.L. Econ. \& Org. 55 (1991), 24 were brought solely in Delaware court and 24 solely in another state court. Of these, 19 of the Delaware cases and 17 of the non-Delaware cases were settled or terminated by the parties' stipulation, and 2 of the Delaware cases and 3 of the non-Delaware cases were dismissed. The remaining cases were inactive or pending at the time of my study. Of the non-Delaware court cases, 5 involved Delaware corporations, of which 4 settled and 1 was dismissed. Of the Delaware court cases, 1 was a double derivative suit - the plaintiff was a shareholder in the parent, an Ohio corporation, while the wholly-owned subsidiary was a Delaware corporation; that case settled. Whether the Delaware cases are classified by the forum (19 settlements of 24 cases) or by the defendant corporation's statutory domicile ( 23 settlements of 29 cases, or 22 settlements of 28 cases, depending on how one classifies the double derivative suit), chi-square tests crosstabulating lawsuit disposition by state (Delaware versus all other states) indicate that there is no statistical difference in the settlement rate across the two groups (the probability values range from .4 to .5 ).

${ }^{358}$ See Bruce L. Hay \& Kathryn E. Spier, Settlement of Litigation, in 3 The New Palgrave Dictionary of Economics and the Law, supra note 24, at 442.

${ }^{359}$ See Richard A. Posner, Economic Analysis of Law 615 (5th ed. 1998). 
Kamar contends, Delaware's law is more uncertain than that of other states because it is more standard-based, then the settlement rate should differ across cases brought in Delaware and those brought in other states.

Moreover, if corporations had found the level of certainty provided by the Delaware courts too low, then when they successfully lobbied Congress to preempt state securities litigation, they would not have supported the "Delaware carve-out" that is contained in the statute, which preserves the right of shareholders to bring fiduciary claims under Delaware law while preempting all other state claims arising in connection with a securities law violation. ${ }^{360}$ There is simply no force to a characterization of Delaware's law as not achieving an "optimal" degree of predictability, when there is no real-world corporate legal system that does a superior job to Delaware in providing a predictable corporate legal regime.

Kamar might seek to assert that his benchmark for indeterminacy is an ideal corporate law and not the examples he provides from other states and federal agencies, but the analytical question whether rules are superior to standards is, in fact, extremely complex. ${ }^{361}$ Although, consistent with Kamar's position, some economists view rules as superior to standards because of lower enforcement costs, ${ }^{362}$ the issue is far from settled. Standards may theoretically be more efficient than rules in the corporate context: Ian Ayres, for example, contends that the use of standards for corporate law is efficient because it is easier for parties to contract for precise rules than standards, and thus a standards approach facilitates the ability of shareholders and managers to contract out of the defaults of judicial decision-making. ${ }^{363}$ Moreover, Kamar does not provide an explanation for why explicit rules would be superior to standards in the fiduciary duty context, beyond those safe harbor rules already present in the Delaware code regarding self-interested transactions.

Casual empiricism would suggest instead that the flexibility of an expert decision-maker's application of a standard (Delaware's approach) is preferable to the "one-size-fits-all" feature of explicit rules in the fiduciary context, ${ }^{364}$ contrary to Kamar's critique. For example, the overwhelming choice of Delaware over other states by large corporations, which have a higher probability of experiencing litigation than small firms, ${ }^{365}$ is consistent with

${ }^{360}$ See, e.g., James D. Cox et al., 2000 Supplement Securities Regulation Cases and Materials 97-98 (2d ed. Supp. 2000) (the "most notable" exemption in the 1998 Securities Litigation Uniform Standards Act preempting state securities actions is the "so-called Delaware carve-out" that preserves state court jurisdiction over certain fiduciary claims).

${ }^{361}$ For a simple introduction to some of the competing considerations, see Posner, supra note 359, at 590-96.

${ }^{362}$ See Louis Kaplow, Rules versus Standards: An Economic Analysis, 42 Duke L. Rev. 557 (1992).

${ }^{363}$ Ian Ayres, Review: Making a Difference: The Contractual Contributions of Easterbrook and Fischel, 59 U. Chi. L. Rev. 1391, 1404 (1992).

${ }^{364}$ As Justice Frankfurter famously remarked, "[T] o say that a man is a fiduciary only begins analysis." SEC v. Chenery Corp., 318 U.S. 80, 85-86 (1943). For an alternative view of the Delaware judiciary that concludes it enhances firm-value rather than produces excessive indeterminacy see Jill E. Fisch, The Peculiar Role of the Delaware Courts in the Competition for Corporate Charters, 68 U. Cin. L. Rev. 1061 (2000).

${ }^{365}$ See, e.g., Kamar \& Kahan, supra note 309 (Table 2) (data from the late 1990s in Towers Perrin 1998 
the claim that fiduciary duty is an area of law for which standards are superior when they will be interpreted by a knowledgeable decision-maker, as compared to the less fact-intensive approach followed by other states that Kamar considers preferable. Moreover, the mix of standards and rules in Delaware case law is consistent with one of the criteria in economic theory for choosing between rules and standards: the frequency of transactions. ${ }^{366}$ The judicial approach to dismissing a derivative action in the absence of a conflict of interest is straightforward and, hence, rule-like in nature, whereas the example Kamar provides of an overly fact-intensive standard is the fairness test applied to breaches of duty in self-interested transactions. ${ }^{367}$ Derivative suit filings are a relatively frequent occurrence, in which the benefit of applying a generalized rule is likely to outweigh the cost of implementing an individualized standard, compared to a court's need to evaluate the substantive content of breaches of the duty of loyalty, claims that typically entail idiosyncratic occurrences in which individualized decisions tend to be the more cost-effective adjudicative approach. ${ }^{368}$ The difficulty of identifying the counterfactua—-how Delaware law could optimally be revised to be less "excessively" fact-intensive—cannot, in the end, be finessed by contending that Delaware could adopt a more determinate fiduciary standard by "limiting or prioritizing the [applicable] criteria." 369 One needs to state exactly what those more refined standards are to assess the validity of the proposition.

Directors and Officers Liability Survey); The Wyatt Co., Wyatt Directors and Officers Liability Insurance Survey (1987) (data from mid-1980s).

${ }^{366}$ See Kaplow, supra note 362.

${ }^{367}$ See, e.g., Kahan \& Kamar, supra note 309.

${ }^{368}$ In my sample of 139 shareholder suits, Romano, supra note 357, of the 139 lawsuits, 55 were derivative suits, with an additional 31 combining derivative and class claims; in contrast, only 22 suits alleged solely a duty of loyalty claim in the complaints, with an additional 48 combining a duty of loyalty claim with another type of claim (such as duty of care or securities law violation). Of course, to avoid a quick dismissal of a derivative suit under the demand requirement, plaintiffs must allege a conflict of interest (a loyalty breach), and thus these figures overstate the presence of genuine fact patterns involving the duty of loyalty. Moreover, the previously noted high settlement rate of these lawsuits reduces the potential pool of cases that judges will have to adjudicate under the fairness standard.

${ }^{369}$ Informing this contention is Louis Kaplow's article advocating the use of rules over standards, or morerule-like standards over less-rule-like standards. See Kahan \& Kamar, supra note 309, at 57 n.101. Kaplow's general analysis does not, however, demonstrate why it is optimal to adopt a more determinate standard than Delaware's standard in the specific context of fiduciary duty law. First, the fiduciary context is not a context in which rules are preferable in Kaplow's model, because corporations have legal counsel on retainer and thus fall into his category of cases where the cost of obtaining advice is low and there is no difference in conforming behavior to rules compared to standards. Kaplow, supra note 362, at 564. Second, it is also not a context in which the ex ante, as opposed to ex post, determination of the legal rule is appropriate. Id. The only criterion of Kaplow's model that could lead to rejecting a standards approach in the fiduciary context is the frequency of the conduct in question: transactions in which a fiduciary issue could arise, such as acquisitions, are fairly common occurrences. But to the extent that the particulars of the complaints in acquisition cases vary significantly and are often idiosyncratic, rules would still be less preferable to standards in this setting. Thus, the reasoning for invoking the frequency criterion for a rule is inapposite in this context as well, and Kamar's objection to the emphasis on standards in Delaware fiduciary law is not theoretically well-grounded. 
The final basis for Kamar's claim that Delaware law is excessively indeterminate is the contention that the Delaware corporate bar benefits from uncertainty because it creates an excessive amount of litigation, thereby increasing attorneys' income. This claim is a variant of earlier work by Jonathan Macey and Geoffrey Miller, who contended that with regard to Delaware law, the key players concerned about Delaware's success in charter competition are the members of the Delaware bar and that they engage in rent-seeking in the legislative process by ensuring that Delaware's code facilitates shareholder suits. ${ }^{370}$

It is true that there are a number of features in Delaware's corporation code, identified by Macey and Miller, that facilitate litigation compared to other state codes, such as the absence of a security-for-expenses provision requiring suing shareholders to post a bond for defense costs. But it is not apparent that all such features harm shareholders, and there are other aspects of Delaware's regime that discourage litigation, such as strict enforcement of the demand requirement in derivative suits, which puts the decision to sue in the hands of the board of directors. ${ }^{371}$ The same is true of Kamar's claim concerning Delaware's court-centered and standard-based jurisprudence: it is not self-evident that shareholders are disadvantaged by this approach, and there are features of Delaware fiduciary law that are quite specific, such as the demand requirement and the approval process for self-interested transactions.

Delaware's commanding position in the charter market no doubt may enable the corporate bar to siphon off a share of Delaware's rents by fashioning a legal regime that increases its income at the expense of share value. But the trade-off will not reach the point at which a firm will be indifferent to staying in Delaware or changing domicile. A competitive market for lawyers reduces the Delaware bar's ability to create a legal regime that increases litigation, and, hence, attorney income, at the expense of shareholder wealth. For example, a study of the legal profession, though not fine-tuned to Delaware corporate practice, finds that lawyers do not earn abnormal returns when income is adjusted for years of education. ${ }^{372}$

Moreover, public corporations, which comprise the bulk of Delaware's chartering business, have in-house counsel who monitor legal costs and often put litigation out to bid and use multiple law firms. Such individuals operate under budget constraints and would not maintain a Delaware domicile if it were imposing undue costs from "excessive" litigation. For Kamar's argument to be sound and for sophisticated in-house counsel to be able to justify expenditure of additional resources on excessive litigation by selecting a Delaware domicile, the costs

${ }^{370}$ See Jonathan R. Macey \& Geoffrey P. Miller, Toward an Interest-Group Theory of Delaware Corporate Law, 65 Tex. L. Rev. 469 (1987). Ian Ayres made a suggestion, analogous to Kamar's, with respect to legislation rather than judicial interpretation, that Delaware might continuously update its code not only to create difficulties for competitors, but also to generate additional litigation. Ian Ayres, Supply-Side Inefficiencies in Corporate Charter Competition: Lessons from Patents, Yachting and Bluebooks, 43 Kan. L. Rev. 541, 558-59 (1995).

${ }^{371}$ See, e.g., Levine v. Smith, 591 A.2d 194 (Del. 1991). 
would have to be offset by a judicial bias in favor of managers, which would reduce the probability of firms' liability to shareholders in Delaware to an insignificant figure compared to the liability level in other states where litigation is not excessive. As previously noted, however, shareholder suits are not dismissed more frequently in Delaware than in other state courts. ${ }^{373}$ Indeed, Kamar does not contend that Delaware law is weighted in that fashion, and it would be difficult to make such a claim. William Cary's argument to that effect has been refuted by subsequent commentators analyzing judicial decisions in Delaware and federal courts; ${ }^{374}$ and indeed, if Cary were correct, the empirical evidence on the shareholder wealth effects of state competition could not have been as favorable as it is.

\section{Is State Takeover Regulation Evidence that a National Regime Would Be Superior to State}

\section{Competition?}

In the 1980s, when hostile takeovers emerged as the mechanism of choice for a control change in which incumbent managers were replaced, the vast majority of states enacted laws that attempted to lower the success of a hostile bid. Because shareholders receive substantial premiums in hostile takeovers, most commentators hypothesized that the objective of such statutes is not to enhance shareholder welfare, but to entrench management. $^{375}$ Indeed, some antitakeover statutes make explicit a non-shareholder-wealth-maximization objective. Such laws, known as "other constituency statutes," permit management to consider interests other than shareholders (that is, factors besides the offered price) in deciding whether to oppose a bid. ${ }^{376}$ Some

${ }^{372}$ See Sherwin Rosen, The Market for Lawyers, 35 J.L. \& Econ. 215 (1992).

${ }^{373}$ See supra note 357.

${ }^{374}$ E.g., Loewenstein, supra note 309.

${ }^{375}$ See, e.g., Easterbrook \& Fischel, supra note 79, at 220-22.

${ }^{376}$ For an analysis of these statutes, see Roberta Romano, What Is the Value of Other Constituency Statutes to Shareholders?, 43 U. Toronto L.J. 533 (1993). I found these statutes had no significant stock price effect on the specific legislative event dates and within two-day event intervals. Id. at 537. John Alexander et al., however, found a significant negative price effect for firms without poison pills or antitakeover charter amendments for two of the statutes that I examined, when a longer event interval of two days before and three days after was used, and for a third statute, enacted by Indiana in 1989, that was improperly included in their sample, because Indiana had an otherconstituency statute in effect since 1986. John C. Alexander et al., Nonshareholder Constituency Statutes and Shareholder Wealth: A Note, 21 J. Banking \& Fin. 417, 427 (1997). I found a negative effect for the earlier Indiana statute, see Romano, supra, at 538, but it is not a "clean" statute in that it was passed in a bill containing another antitakeover law, a control share acquisition provision. I did not find any difference for firms with or without defensive tactics in place, but I did not investigate this effect for each state statute separately as did Alexander et al., and therefore the two studies' results regarding the interaction between defensive tactics and other-constituency statutes are not directly comparable. In addition, my sample consisted of relatively large firms, as it was constructed solely from NYSE listings, while Alexander et al. included firms traded on the American Stock Exchange and NASD's Automated Quotation System (NASDAQ), which are, on average, smaller than NYSE firms given the exchanges' different listing requirements. Because at least one study has found that it is small firms that experience negative price effects from takeover statutes, see M. Andrew Fields \& Janet M. Todd, Firm Size, Antitakeover Charter 
commentators, however, contended that takeover defenses benefit shareholders by solving a coordination problem that limits their bargaining ability to extract the highest price from the bidder. ${ }^{377}$

In a recent article, Lucian Bebchuk and Allen Ferrell focus on the takeover statute phenomenon to challenge the efficacy of state competition. ${ }^{378}$ Taking the side of the proponents of takeovers and opponents of takeover statutes, ${ }^{379}$ they consider the widespread adoption of takeover statutes as evidence that competition is a "race to the bottom" that produces laws favoring managers' interests over those of shareholders. Although I have discussed the significance of takeover statutes for assessing the efficacy of state competition in detail in prior work, ${ }^{380}$ this section responds to Bebchuk and Ferrell's restatement of this objection to competition.

It should, however, be underscored that despite Bebchuk and Ferrell's critique, no advocate of charter competition contends that state competition is perfect. Rather, the position of proponents of competition is that on average it benefits investors and that its legal product is far superior to what a centralized regime would produce. Entering into the positive assessment of the efficacy of competition are three factors: (1) the view that the data on competition's enhancement of shareholder value outweigh any potential negative effect of the behavior of the states on takeovers; (2) the stark differentiation between the product of laws involving takeovers and other corporate code provisions; and (3) the consideration that in contrast to Delaware, the national government would have little incentive or ability to be responsive to changing business conditions. Not only would there be reduced incentives to respond due to the absence of competition, but there also would be little financial incentive to respond, as the revenues from the incorporation business, which averaged $17 \%$ of total taxes collected by Delaware from 1966-1998, ${ }^{381}$ would be an insignificant percentage of the federal budget. ${ }^{382}$ Bebchuk and Ferrell

Amendments, and the Effect of State Antitakeover Legislation, 21 Managerial Fin. 35 (1995), the difference in the two studies' samples may explain the difference in the statistical results.

${ }^{377}$ See, e.g., William J. Carney, Shareholder Coordination Costs, Shark Repellents, and Takeout Mergers: The Case Against Fiduciary Duties, 1983 Am. B. Found. Res. J. 341.

${ }^{378}$ Bebchuk \& Ferrell, supra note 180.

${ }^{379}$ Id. at 1182. As discussed in infra note 394, Bebchuk has advocated enactment of takeover statutes that require shareholder approval for a bid to proceed and his criticism of the output of state competition in this area can thus be understood, at least in part, as an objection that not all states adopted his preferred statute, or solely his preferred statute ( since the adopters often enacted additional takeover statutes as well), rather than as an objection to all takeover regulation.

${ }^{380}$ E.g., Romano, supra note 22, at 52-84.

${ }^{381}$ Roberta Romano, The Advantage of Competitive Federalism for Securities Regulation (forthcoming 2001) (table 4-1).

${ }^{382}$ This is not to say that there would be no financial incentive for the federal government to respond, as members of Congress are responsive, for instance, to campaign contributions, but that is a far more expensive and less reliable incentive device for investors than the incentive mechanisms of state competition. In addition, Congress acts more slowly than state legislatures, as the U.S. political system is founded on extensive checks and balances that impede legislative innovation. For example, congressional reversals of Supreme Court decisions invalidating federal statutes averaged 2.4 years from opinion to reversal, whereas the Delaware legislature took only 1.5 years to 
minimize the import of all three of these factors regarding the relative efficacy of state competition. But for state competition to be preferable to a single national regime, the key issue is not perfection, but the relative performance of institutions.

\section{Delaware and Takeover Regulation}

Most of the controversy among corporate law commentators over the efficacy of takeover defenses is not whether takeovers benefit shareholders-the data on this are unequivocal—but whether the net effect of defenses — increased competition among bidders (that is, takeover auctions)—benefits shareholders. The debate, in essence, is whether the increased premium shareholders would receive in an auction would be more than offset by the reduced probability that a bid would be received in the first place, as bidders would engage in less search for targets if their likelihood of success was reduced because other bidders, free-riding on the first bidder's search, could offer a higher price. Whether bidders would, in fact, reduce their search - that is, whether they would not be adequately compensated in an auction-has also been a subject of debate. ${ }^{383}$

Corresponding to the scholarly debate over the efficacy of auctions, the empirical literature evaluating takeover defenses has produced mixed results. Consistent with the position that restricting hostile takeovers is against shareholder interest, some event studies find that the enactment of antitakeover laws produced negative stock price reactions, although others find the price effect is statistically insignificant. ${ }^{384}$ Similarly, other takeover restrictions undertaken at the firm level, such as antitakeover charter amendments and adoption of golden parachutes, often do not have a significant negative price effect and, on occasion, even have a significant positive effect. ${ }^{385}$ In addition, the evidence on whether there is a tradeoff between higher premia in auctions and fewer

respond with legislation to a controversial decision on director liability, Romano, supra note 22, at 49. In addition, state takeover laws are often enacted within a few weeks or months of proposal. See, e.g., Roberta Romano, The Political Economy of Takeover Statutes, 73 Va. L. Rev. 111, 128, 131-32 (1987) (discussing political process in Connecticut).

${ }^{383}$ See, e.g., Ronald J. Gilson, Seeking Competitive Bids Versus Pure Passivity in Tender Offer Defense, 35

Stan. L. Rev. 51 (1982) (supporting takeover auctions by providing examples of how a first bidder can recoup the risk of lost information costs).

${ }^{384}$ The most comprehensive study, which aggregates the effect of forty statutes, finds a small but significant negative stock price effect, see Jonathan M. Karpoff \& Paul H. Malatesta, The Wealth Effects of SecondGeneration State Takeover Legislation, 25 J. Fin. Econ. 291 (1989), although many studies of individual statutes do not find significant stock price effects, see Romano, supra note 22, at 60-67 (reviewing results of empirical studies on takeover statutes).

${ }^{385}$ E.g., Harry DeAngelo \& Edward M. Rice, Antitakeover Charter Amendments and Shareholder Wealth, 11 J. Fin. Econ. 329 (1983) (insignificant effect); Scott C. Linn \& John J. McConnell, An Empirical Investigation of the Impact of 'Antitakeover' Amendments on Common Stock Prices, 11 J. Fin. Econ. 361 (1983) (positive or insignificant effect); Gregg Jarrell \& Annette Poulsen, Shark Repellents and Stock Prices: The Effects of Antitakeover Amendments Since 1980, 19 J. Fin. Econ. 127 (1987) (insignificant effect for fair price amendments, the majority of sample); James A. Brickley et al., Ownership Structure and Voting on Antitakeover Amendments, 20 J. Fin. Econ. 267 (1988) (insignificant effect); Richard Lambert \& Donald Larckner, Golden Parachutes, Executive Decision-making 
initial bids is inconclusive: while auctions do increase target premiums, the rate of takeover auctions does not appear to differ across states with and without takeover statutes, and there are conflicting findings concerning whether the number of takeovers has been reduced by the presence of a takeover statute or defensive tactics and whether premiums are higher for firms with defenses or incorporated in states with takeover statutes. ${ }^{386}$

Bebchuk and Ferrell's critique of state action on takeovers is supported empirically by the subset of findings that takeover statutes (and some takeover defenses) have negative wealth effects. However, their analysis overlooks key differences between Delaware's takeover statute and those of other states and between the political process in the enactment of a takeover statute compared to other corporate law provisions. Their analysis also neglects the dynamics of the national politics, which must be factored in if one is to consider the alternative to state competition-a national regime. These omissions render implausible their conclusion that the enactment of takeover laws requires a "reassessment" of state competition for corporate charters and, by implication, the suggestion that competition should be scrapped in favor of a national regime, as they expressly identify their position with William Cary, who advocated replacing state competition with a federal regime. ${ }^{387}$

and Shareholder Wealth, 7 J. Acct. \& Econ. 179 (1985) (significant positive effect); but see Sanjai Bhagat \& Richard Jefferis, Voting Power in the Proxy Process: The Case of Antitakeover Charter Amendments, 30 J. Fin. Econ. 193 (1991) (after observing that returns around proxy mailings are higher for firms where no antitakeover amendments are proposed than for firms that make such proposals, they find a significant negative effect from a broad set of antitakeover amendments when adjusting for anticipation of such a proposal in a cross-sectional regression based on firm-specific characteristics).

${ }^{386}$ See, e.g., Jo Watson Hackl \& Rosa Anna Testani, Note, Second Generation State Takeover Statutes and Shareholder Wealth: An Empirical Study, 97 Yale L.J. 1193 (1988) (states with second generation statutes had smaller increase in number of takeovers, controlling for incorporations, than states with no such statutes, but bid premiums did not vary across regulating and non-regulating states, and auctions were not more frequent in states with statutes); Robert Comment \& G. William Schwert, Poison or Placebo? Evidence on the Deterrence and Wealth Effects of Modern Antitakeover Measures, 39 J. Fin. Econ. 3 (1995) (takeover rates not lower for firms covered by takeover statutes or poison pill defenses).

${ }^{387}$ Bebchuk \& Ferrell, supra note 180, at 1170; Cary, supra note 71. In a more recent article, Bebchuk and Ferrell propose permitting firms to choose their takeover regime, with a federal option in addition to their incorporation state, a proposal that parallels my proposal to open securities regulation up to competition. Bebchuk \& Ferrell, supra note 307. This proposal is not an alternative to state competition, but it is an endorsement of competition, as firms would choose their takeover regime from among different sovereigns. It is thus a proposal that cedes the debate over corporate charters to the side in favor of state competition. The specifics of the proposal are, however, puzzling for two reasons. First, as discussed in the text, there is no guarantee that Congress would enact a takeover statute whose substantive content is identical to Bebchuk and Ferrell's proposal, and there is considerable evidence that in all likelihood, it would not do so. Second, under existing Delaware law, firms can voluntarily adopt Bebchuk and Ferrell's preferred takeover regime, but none appears to have done so. Bebchuk and Ferrell presumably believe that this state of affairs is a function of managers' trumping shareholder preferences under state competition; the alternative explanation, and in my judgment the more compelling one, is that their proposal is not as desirable as they claim. Because the optimal takeover regime is uncertain given the unresolved empirical literature on the tradeoff between premiums, auctions, and bid probabilities, had Bebchuk and Ferrell truly wanted to enhance shareholder choice through federal intervention-their stated goal, see id. at 113-rather than to direct the substantive content of federal takeover law to the rule that they hypothesize is optimal, they would have recommended instead a federal 
In particular, the critical factor that Bebchuk and Ferrell do not adequately address in maintaining that state takeover laws should be considered paradigmatic of all corporate code provisions is that Delaware, the state with the largest stake in the chartering business, stands out as an anomaly in the pattern of takeover legislation on which Bebchuk and Ferrell's argument relies. For instance, in contrast to its position as an innovator of corporation code provisions, Delaware has persistently been a laggard behind other states in the takeover statute context. ${ }^{388}$ Its first-generation takeover statute was enacted in 1975, seven years, and seven states, after the first such state law was enacted. ${ }^{389}$ It did not adopt a second-generation statute until after these statutes were upheld by the Supreme Court in CTS Corp. v. Dynamics Corp. of America, ${ }^{390}$ in contrast to twenty other states that had acted prior to the decision. ${ }^{391}$

More important, Delaware's takeover statute is considerably less restrictive of bids compared to those of most, if not all, other states. For example, bidders are exempt from the statute entirely if they obtain $85 \%$ of the shares in their offer, and its restrictions on bidders have a shorter duration, three years, compared to those of other states, such as New York's five years. ${ }^{392}$ Greater flexibility and protection for hostile bidders was also a defining characteristic of Delaware's first-generation takeover statute, which did not have a hearing requirement, the prime method by which those early statutes sought to defeat hostile bids, and in contrast to most states' firstgeneration takeover laws, it was optional. ${ }^{393}$ Correspondingly, in contrast to the second-generation antitakeover statutes of other states, the Delaware statute did not have a negative stock price effect. ${ }^{394}$ While Bebchuk and

procedural requirement that shareholders have initiation rights to create and remove takeover defenses, which would let shareholders select their own takeover regime.

${ }^{388}$ See Romano, supra note 21, at 237-40 (Delaware is either the first or one of the first states to adopt major corporate law innovations apart from takeover statutes).

${ }^{389}$ Romano, supra note 22, at 59.

${ }^{390}$ CTS Corp. v. Dynamics Corp. of Am., 481 U.S. 69 (1987).

${ }^{391}$ See Romano, supra note 299, at 461-64.

${ }^{392}$ See, e.g., id. at 464 n.6.

${ }^{393}$ See, e.g., Romano, supra note 22, at 59. First generation statutes were structured as securities regulations, reviewing and postponing the consummation of hostile bids, similar to the federal takeover law and struck down as burdens on interstate commerce in Edgar v. MITE, 457 U.S. 624 (1982); second generation statutes are structured as corporate governance measures and are typically optional statutes. These statutes were enacted in a few states immediately following the Edgar v. MITE decision and in virtually all states after the Supreme Court upheld Indiana's second-generation statute, a control share acquisition law, in CTS v. Dynamics Corp. of America, 481 U.S. 69 (1987).

${ }^{394}$ See John S. Jahera \& William N. Pugh, State Takeover Legislation: The Case of Delaware, 7 J. L. Econ. \& Org. 410, 416-19 (1991) (finding insignificant or positive returns over eight two-day event intervals); Karpoff \& Malatesta, supra note 384, at 315 (finding an insignificant price effect over two-day event interval). It is at the least curious for Bebchuk and Ferrell to conclude from Delaware's enactment of a takeover statute, which is considerably less restrictive of bidders than other statutes and had no negative stock price effect, that state competition is an abysmal failure and to imply that it ought to be scrapped for national regulation. Bebchuk's own proposal for a takeover statute, a law requiring a majority vote of the target shareholders to approve a takeover before it can proceed, is indistinguishable from the control share acquisition statutes adopted by numerous states, which permit a bidder to acquire shares (or equivalently, to vote the shares it acquires) only upon a vote of the majority of the other 
Ferrell belittle these key features of Delaware's takeover legislation, they provide no evidence, nor do they maintain, that the optimal regime entails no such legislation, which is the conclusion implied by their position that an analysis showing Delaware's statute is more facilitative of bids than other states' laws is evidence that state competition works poorly.

Finally, John Coates has sought to measure the extent to which the default rules of a state corporation code restrict hostile bids by delaying their success. He concludes that Delaware is the least restrictive of any state (it has the lowest score on a scale in which the lower the score, the shorter the time a bid can be delayed, and hence the easier it is for a hostile bidder to succeed). ${ }^{395}$ While firms can and do change the Delaware default rules, shareholders have to approve the changes if the provisions are in the corporation's charter or are able to reverse them if they are in the bylaws.

Consistent with the data on Delaware's takeover statute and corporation code defaults, Robert Daines finds that Delaware firms are more likely to receive a takeover bid than firms of other states. ${ }^{396}$ The gulf between Delaware and other states regarding takeover legislation is considerable, and it has real consequences, notwithstanding Bebchuk and Ferrell's attempt to minimize the difference. This is an important finding, because Delaware is the leading incorporation state and its laws govern the majority of large publicly-traded corporations, entities for which Bebchuk and Ferrell's concern regarding managerial opportunism is highest, as these firms are the least likely to have controlling shareholders (i.e., managers owning a substantial percentage of the firm).

One reason why Delaware's statutory output is different from other states regarding takeover regulation is that its political dynamics differ dramatically from the politics of other states. There are more bidders, as well as more targets, incorporated in Delaware than in other states, and no one target corporation can have significant legislative influence in obtaining a favorable law, as has been true in the passage of takeover laws in almost all other states. ${ }^{397}$ Bidders tend to focus their energies on lobbying in states where the rewards are greater-where

shareholders in approval of the transaction. See Lucian A. Bebchuk, Toward Undistorted Choice and Equal Treatment in Corporate Takeovers, 98 Harv. L. Rev. 1695 (1985); Ohio Rev. Code Ann. §§ 1701.0, 1701.831 (2001); Ind. Code Ann. $\S \S 23-1-42-1$ to 23-1-42-11(2000). Yet in contrast to the Delaware statute that had an insignificant positive price effect, the Indiana control share acquisition statute that tracks Bebchuk's recommended takeover law ironically had a significant negative price effect. See, e.g., Karpoff \& Malatesta, supra note 384, at 315; William N. Pugh \& John S. Jahera, State Antitakeover Legislation and Shareholder Wealth, 13 J. Fin. Res. 221 (1990). The price effect of the Ohio statute was, however, insignificantly negative. Id.

${ }^{395}$ See Coates, supra note 295.

${ }^{396}$ Daines, supra note 143.

${ }^{397}$ For lists of the specific takeover targets that were the source of state takeover laws see Henry N. Butler, Corporation-Specific Antitakeover Statutes and the Market for Corporate Charters, 1988 Wis. L. Rev. 365; Romano, supra note 299, at 461 n.11. This is one of the reasons why states have multiple takeover laws. A law is tailored to help a specific target stop a particular bid, and when the next in-state target faces a bidder that has adapted itself to the existing defenses, including the prior takeover legislation, that target needs a new form of defense to be codified to protect it. Targets turn to legislatures because in the context of a well-priced bid, their 
there is a higher number of prospective targets—and where their efforts are more likely to pay off-where they have local contacts; both of these factors are true of Delaware. In addition, in contrast to other states, in Delaware all changes to the corporation code are broadly vetted by the corporate bar, and the legislature only considers revisions approved by the bar committee. ${ }^{398}$ The diversity in representation in corporate clients across the bar has ensured that all parties have input into the drafting process.

Bebchuk and Ferrell overlook the distinctive features of Delaware politics and maintain instead that corporate managers only lobby for rules favorable for targets when it comes to takeover legislation. ${ }^{399}$ Although this is not an implausible initial hypothesis, as many individuals care more about adverse outcomes than favorable ones, ${ }^{400}$ the members of the corporate bar, and not corporate managers, are the key players in the Delaware legislative process. ${ }^{401}$ If legal counsel were to lobby for laws that benefit managers at the cost of reducing share values, the value of their human capital would be diminished, as Delaware could lose its primacy among incorporation states. Attorneys in other states do not have an equivalently valuable asset to deplete; and since they typically represent solely targets, whereas Delaware lawyers tend to represent both sides of deals, non-Delaware lawyers have an additional reason to support laws favoring target management: after an acquisition, the combined entity most often uses the acquirer's counsel, not the target's. It is simply not in the Delaware bar's self-interest to eliminate the possibility of successful hostile bids.

Furthermore, given contemporary compensation contracts that provide executives with considerable sums of cash upon control changes, the scenario that Bebchuk and Ferrell postulate concerning managers' incentivesavoiding acquisition at all costs-is dated. Managers are far more likely to use defenses to increase the bid price than to thwart bids, because they obtain increased equity compensation upon takeovers as stock options accelerate and often increase in amount upon the bid. ${ }^{402}$

In addition, while the line between target and acquirer is not always sharp, there are firms that have extensive acquisition programs, and the vast majority of firms that have made an acquisition, and, in particular, a

shareholders will not approve the adoption of the defenses they are able to obtain from the legislature.

${ }^{398}$ See Justice Andrew G.T. Moore, II, State Competition, Panel Response, 8 Cardozo L. Rev. 779, 780-81

(1987). Takeover laws in other states often are adopted under unusual circumstances compared to other provisions in corporate codes - in specially called legislative sessions, or without review by the relevant bar committee or public hearings - as legislatures act to assist a local target's effort to thwart a takeover by a foreign (out-of-state) bidder.

See, e.g., Romano, supra note 382.

${ }^{399}$ Bebchuk \& Ferrell, supra note 171, at 1176-77.

${ }^{400}$ See, e.g., Hardin, supra note 148, at 82-83.

${ }^{401}$ See, e.g., Moore, supra note 398; Macey \& Miller, supra note 370.

${ }^{402}$ Executive Compensation Issues in M\&A Panel, University of Miami School of Law Center for the Study of Mergers \& Acquisitions Fourth Annual Institute (Feb. 11, 2000) (comments by Barbara Nims, Esq., Davis Polk \& Wardwell, and members of audience). 
hostile one, are incorporated in Delaware. ${ }^{403}$ The incentive of these firms' managers is to ensure that Delaware's legal regime does not restrict takeovers, as it has the largest pool of targets and not, as Bebchuk and Ferrell assert, to lobby for antitakeover legislation. By focusing exclusively on the domicile of the manager, Bebchuk and Ferrell have lost sight of the fact that acquirer managers recognize that Delaware is the home of the vast majority of potential targets, and for such managers, having a law facilitating bids is more important than concern about their own firm's vulnerability to a bid under such a statute.

Finally, in contrast to other states, no domestic Delaware corporation employs a significant workforce instate that could offset the magnitude of franchise tax collections and provide clout to obtain takeover legislation. Consequently, concerns other than stock-price maximization, such as protecting target firm jobs, which tend to make legislators partial to managers', rather than shareholders', position regarding the success of a bid, do not affect the making of acquisition law in Delaware as much as they do in other states. ${ }^{404}$

Bebchuk and Ferrell suggest that shareholders are easily exploited by managers who select takeover regimes that enable them to expropriate shareholder wealth, but this is simply not so. Not only does the enactment of multiple statutes indicate that such legislation does not stop bids, but the experience in one state that adopted a uniquely restrictive statute is instructive. When Pennsylvania passed a takeover disgorgement statute that was considered to be more Draconian than any other antitakeover law, ${ }^{405}$ institutional investors pressured managers to opt out of the statute, and a majority of firms did so (of 199 publicly traded firms whose choices could be identified, 127 opted out of all or part of the statute, while 72 did not). ${ }^{406}$ Moreover, other states did not

${ }^{403}$ For example, of all tender offers for which at least one firm was traded on a national exchange from 195885 , the database used for predicting the adoption of a takeover statute in Romano, supra note 382, at 143, there were 49 NYSE-listed hostile bidders incorporated in Delaware, compared to a maximum of 6 in any other state, and 95 NYSE-listed acquirers incorporated in Delaware, compared to a maximum of 14 in any other state.

${ }^{404}$ State legislatures often enact takeover statutes because they are concerned with local employment levels, even though little evidence exists that, on average, hostile takeovers result in the loss of production level jobs, see Roberta Romano, A Guide to Takeovers: Theory, Evidence and Regulation 9 Yale J. on Reg. 119, 137-142 (1992). For example, the Connecticut legislature speedily called hearings on legislation designed to protect a local firm from a hostile bid, because it was alleged that the takeover would result in substantial layoffs. Connecticut did not enact the statute, despite earlier predictions that it would, after the state United Auto Workers (UAW) union indicated that it did not support the legislation; it appears that the local firm's managers were less "pro-union" than the bidder, which reached an agreement with the UAW to, among other matters, remain neutral if the UAW sought to unionize the local plant after the takeover. See Dan Haar, House Rejects Takeover Measure; Vote Denies Echlin Protection Against SPX's Hostile Bid, Hartford Courant, Mar. 26, 1998, at D1.

${ }^{405}$ This interpretation is supported by evidence of a significant negative stock price reaction to the legislation. See, e.g., Jonathan Karpoff \& Paul Malatesta, State Takeover Legislation and Share Values: The Wealth Effects of Pennsylvania's Act 36, 1 J. Corp. Fin. 367 (1995); Samuel H. Szewczyk \& George P. Tsetsekos, State Intervention in the Market for Corporate Control: The case of Pennsylvania Senate Bill 1320, 31 J. Fin. Econ. 3 (1992).

${ }^{406}$ See Romano, supra note 22, at 68-69. The percentage opting out is higher for the larger firms (74\% of exchange-listed Pennsylvania corporations opted out compared to $60 \%$ of firms traded on NASDAQ or over-the- 
copy the Pennsylvania statute. Managers do not operate in the environment that Bebchuk and Ferrell imagine, which would permit them to ignore with impunity investors' wishes regarding takeover regulation.

In contrast to the situation in Pennsylvania, investors have not pressured managements to opt-out of other takeover statutes, including Delaware's, whereas they routinely press managers to rescind or subject to shareholder approval firm-level defenses, such as poison pills.407 The most plausible explanation of this behavior is that while they disagree with managers concerning specific defensive tactics, they do not perceive that takeover statutes significantly affect the initiation or outcome of a takeover bid, rather than the characterization of Bebchuk and Ferrell, that they are helpless victims of managers' expropriative regime choice. ${ }^{408}$ This contention is supported by Robert Comment and G. William Schwert's finding that state takeover laws do not reduce the number of bids. ${ }^{409}$ Indeed, notwithstanding Bebchuk and Ferrell's picture of a "fortress" corporate America constructed with the assistance of state legislatures, ${ }^{410}$ as takeover statutes proliferated across states, so did the number of acquisitions. The thesis that Delaware has a relatively mild takeover statute is, accordingly, not an "excuse" for state competition, as Bebchuk and Ferrell assert, ${ }^{411}$ but, rather, compelling evidence that the state most concerned about charter competition is the most responsive to shareholder desires.

\section{Would National Takeover Legislation Be Superior to the Output of State Competition?}

Because there would be no competing regimes, whose takeover rules could differ, the national government might not feel as pressured to revise its takeover law repeatedly to thwart hostile bids, but it also would not be as constrained regarding the level of protection it chose by the presence of alternative opportunities facilitating bids compared to states in a competitive federal system. In fact, the idealized system of national regulation that Bebchuk and Ferrell advocate in place of state competition is a pipe dream. The congressional legislative process regarding takeovers is similar to that of most states, resembling more closely the Pennsylvania than Delaware dynamics, ${ }^{412}$ and therefore the political failure, which is the linchpin of Bebchuk and Ferrell's critique of state

counter).

407 See Gillan \& Starks, supra note 293, at 286 (of 2,042 shareholder proposals offered between 1987 and 1994,249 were directed at repealing poison pills while only 17 were directed at opting out of takeover statutes).

${ }^{408}$ Given the small but statistically significant negative price effect picked up in Karpoff and Malatesta's comprehensive event study of takeover statutes cited in supra note 384, this explanation of investor behavior regarding takeover statutes would mean either that the market has changed its assessment of the significance of the statutes, or the takeover environment itself has changed (either a learning or a real economy effect due to, for instance, the evolution of poison pill defenses into a more prominent strategic position than the older statutory defenses).

${ }^{409}$ Comment \& Schwert, supra note 386.

${ }^{410}$ Bebchuk \& Ferrell, supra note 180, at 1180.

${ }^{411} I d$. at 1198.

${ }^{412}$ Romano, supra note 299, at 475-85. 
competition, that an entrenchment-motivated management controls the legislative process, , will not miraculously disappear when Congress is the object of lobbying. The Williams Act, for example, is widely recognized as favoring incumbent management over bidders by increasing the cost of a bid through delay, ${ }^{413}$ and it is much more effective at delaying a bid and inducing an auction than any of the second-generation state statutes. Hence, it is highly improbable that Congress would adopt the form of takeover regulation that Bebchuk and Ferrell believe is optimal. It is also worth noting that firms in states that have enacted statutes indistinguishable from Bebchuk's proposed regulation experienced significant negative stock price effects from the legislation. ${ }^{414}$

The difference between Congress' Ikely response and Bebchuk and Ferrel's proposal is not simply speculation. Bebchuk and Ferrell praise as preferable to the output of state competition, and, hence, as a standard for federal regulation, the takeover rules in the London Code of Conduct, established by the City's Panel on Takeovers and Mergers, which regulates takeover bids in the United Kingdom. ${ }^{415}$ The London Code requires bidders to buy all target shares and prohibits defensive tactics without shareholder approval once a bid has commenced. Congress, however, expressly did not adopt the takeover rules embodied in the London Code, although it surely could have done so. In fact, the Williams Act expressly permits partial bids (which the London Code bans). Moreover, Congress never even considered restricting defenses when enacting the Williams Act, which instead increased management's defensive arsenal by providing a basis for litigation (bidders' failure to comply with various aspects of the Act). Indeed, while over 200 bills regulating takeovers were introduced in Congress from 1963 through 1987, five years before the enactment of the Williams Act to the Supreme Court's decision upholding state takeover regulation, which turned takeover lobbying efforts to the states and away from federal legislation, of 67 bills directed at contested bids, 30 were directed solely at regulating hostile bids, while 11 were directed solely at regulating defensive tactics or greenmail. ${ }^{416}$ The remaining 26 bills included elements of both forms of regulation, but often had provisions permitting firms to opt out of restrictions on management defensive tactics but not out of restrictions on hostile bidders. In other words, the type of legislation of most interest to members of Congress was decidedly against facilitating hostile bids or allocating greater authority to shareholders than to managers over the bidding process, which is Bebchuk and Ferrell's objective for federal legislation.

${ }^{413}$ See, e.g., Easterbrook \& Fischel, supra note 79, at 224-25.

${ }^{414}$ See supra note 394.

${ }^{415}$ See Bebchuk \& Ferrell, supra note 171, at 1192.

${ }^{416}$ Romano, supra note 299 , at $470-73$. The majority of the bills were directed at regulating tender offers generally ( 86 bills), restricting acquisitions in specific industries ( 49 bills) or by foreign purchasers ( 49 bills), and discouraging takeovers by increasing the tax on such transactions ( 28 bills). Id. at 472 . One would be hard-pressed to characterize these bills as being even remotely related to the type of regulation that Bebchuk and Ferrell seek from the federal government. 
The contrast between the provisions of the London Code and the Williams Act and the content of proposed federal legislation make clear that the congressional political process bears no resemblance to Bebchuk and Ferrell's perception of it, which is the premise for their preference for national legislation over state competition. ${ }^{417}$ It also indicates that their subsequent proposal for a federal takeover law option that would duplicate the London Code and eliminate defenses is utterly unrealistic as to what would be the output of any federal takeover legislation, whether optional or mandatory.

Equally important, the provisions of the London Code that Bebchuk and Ferrell praise are beside the point in the U.S. takeover context. The London Code provision that bans midstream defenses without shareholder approval, absent from state corporation codes, has little practical significance for U.S. corporations. The only defense that U.S. firms can today adopt midstream is a poison pill, which can also be adopted before a bid is in the offing and hence is not effectively prohibited by the London Code provision. This is because institutional investors vigorously oppose midstream charter amendments that erect takeover defenses, and accordingly, since the late 1980s, U.S. corporations have not been able to propose successfully defensive charter amendments such as classified boards or elimination of cumulative voting. ${ }^{418}$ In addition, the use of a poison pill defense to thwart a bid is limited, as a pill can be eliminated by a successful proxy fight, and state courts have not permitted managers to adopt provisions midstream that impede proxy fights. ${ }^{419}$

The other London Code provision, the $100 \%$ offer rule, is of even less significance than the restriction on defensive tactics as evidence of a political failure in state takeover law. Several states have, in fact, enacted takeover statutes with identical effect, the requirement that bidders make $100 \%$ offers. ${ }^{420}$ Many firms have also

${ }^{417}$ It should be noted that the London Code is not, as Bebchuk and Ferrell maintain, a market-based regulatory choice, and hence the optimality of the London Code is as questionable as the state laws that they find wanting. Although the Takeover Panel is not an official state organ or self-regulatory body, the official selfregulatory bodies that have monopoly licensing power over market professionals require their compliance with the Code of Conduct, and it is therefore decidedly not voluntary. More over, the Bank of England was a key force behind the Takeover Panel's creation and appoints many of its members. See Brian R. Cheffins, Company Law: Theory, Structure, and Operation 407 (1997).

${ }^{418}$ See, e.g., John C. Coates IV, Takeover Defenses in the Shadow of the Pill: A Critique of the Scientific Evidence, 79 Tex. L. Rev. 271, 325, 334 (2000) (shareholders did not approve midstream defenses throughout the 1990s).

${ }^{419}$ See, e.g., Quickturn Design Sys. v. Mentor Graphics Corp., 721 A.2d 1281 (Del. 1998) (striking down deadhand pill that impaired proxy fight). While proxy fights are not likely to take much longer than the success of a tender offer itself, depending upon a firm's specific charter and bylaws and state law defaults, John Coates estimates that proxy fights can take from six to eighteen months. Coates, supra note 295.

${ }^{420}$ See, e.g., Me. Rev. Stat. Ann. tit. 13-A, § 910 (redemption rights statute) (West 1981). Other statutes have a similar effect: by restricting what bidders for less than $100 \%$ of the stock (or who obtain less than $100 \%$ ) can do, they are intended to result in the offer of only bids for $100 \%$ of the shares. See, e.g., Md. Code Ann., Corps. \& Ass'ns §§ 3-601-3-604 (2001) (fair price provision); Del. Code Ann. tit. 8, § 203 (2001) (business combination freeze statute); and Cede \& Co. v. Technicolor, Inc., 648 A.2d 289 (Del. 1996) (reading appraisal statute to require payment 
adopted such provisions in their charters, with or without specific state authorization. ${ }^{421}$ In addition, with the development of junk-bond financing in the 1980s, partial takeovers, although permitted, have become a largely irrelevant factor in the U.S. acquisition market. Finally, and most importantly, the research on premiums and success rates of full and partial bids indicates that partial bids do not produce a prisoner's dilemma in which shareholders are forced to tender into a low-ball bid (because they fear a majority will tender and they will receive less in a second-stage freezeout if they do not), which is the rationale for prohibiting such bids: blended premiums in two-tier bids are not significantly different from the premiums in $100 \%$ offers; when there is competition between $100 \%$ and two-tier offers, the one with the highest value calculated by the blended premium wins; and partial bids offering small premiums are rejected at high rates. ${ }^{422}$

Bebchuk and Ferrell focus on takeover statutes as the core of the case against state competition, because much state activity in corporate law is legislative, and, as discussed earlier, the diffusion process of code reforms is considered a sign of robust competition. . But corporate counsel have never considered takeover statutes to provide particularly effective defenses; the statutes serve principally to assist targets that have not adopted adequate defenses prior to the emergence of a hostile bid. Rather, counsel consider the poison pill to be a firm's most effective defense. Cognizant of this fact, Bebchuk and Ferrell do criticize the Delaware judiciary for permitting the use of poison pills, adding this to their list of complaints against state competition. But not all commentators have accepted Bebchuk and Ferrell's negative assessment of defenses such as poison pills; as previously noted, some have viewed defenses as a useful bargaining mechanism to obtain higher prices. ${ }^{423}$ From such a perspective, judicial approval of poison pills is not a failure of state competition. Bebchuk and Ferrell also overstate the latitude that Delaware courts permit managers to exercise with respect to defensive tactics. Not only have Delaware courts required a pill to be redeemed when it has ceased to serve its function-increasing the bid price — and is being used solely to entrench management, ${ }^{424}$ but they also have repeatedly refused to permit

of premium in second-step merger after a takeover bid that is higher than offering bid and thereby imposing huge penalty on partial offers).

${ }^{421}$ See, e.g., Linn \& McConnell, supra note 385; Jarrell \& Poulsen, supra note 385.

${ }^{422}$ See Robert Comment \& Gregg A. Jarrell, Two-Tier and Negotiated Tender Offers: The Imprisonment of the Free-Riding Shareholder, 19 J. Fin. Econ. 283 (1987).

${ }^{423}$ In this regard, it should be noted that Bebchuk and Ferrell mischaracterize positions in the literature. They state that "there is a large body of literature that argues that managers should be completely prohibited from engaging in defensive tactics - a literature which includes contributions by leading advocates of state competition" and cite in support of this statement articles by Ronald Gilson and the author of this paper. Bebchuk \& Ferrell, supra note 180, at 1184, 1184 n.49. Neither Gilson's article nor my article advocates that management should be prohibited from engaging in all defensive tactics.

${ }^{424}$ See City Capital Assoc. v. Interco, 551 A.2d 787 (Del. Ch. 1988). Although the Delaware Supreme Court has indicated that if the Chancery Court in Interco substituted its own judgment for what was a "better deal" over that of the board of directors, then the analysis was improper under the Unocal standard, see Paramount Communications, Inc. v. Time Inc., 571 A.2d 1140, 1153 (Del. 1989), it did not indicate that it would have reversed on 
managers to adopt poison pills that cannot be eliminated by shareholder action (such as deadhand pills that prevent shareholders from electing new directors who will redeem the pill in a hostile bidder's favor) or otherwise impede the proxy process midstream. ${ }^{425}$

In contrast to the Delaware courts, federal district courts making state law rulings have permitted managements to craft poison pills that shareholders cannot eliminate after a successful proxy fight. ${ }^{426}$ It is ironic that district courts, the rulings of which Bebchuk and Ferrell would surely disapprove, as they hinder shareholders' ability to receive bids, are the very same courts that would be interpreting the national takeover law that Bebchuk and Ferrell advocate in place of competition, in contrast to the Delaware courts, whose rulings on the identical issue Bebchuk and Ferrell would presumably approve since they protected shareholders from management exploitation through unredeemable poison pills. Yet the Delaware courts, which are the courts found to be falling short by Bebchuk and Ferrell as having favored managers over shareholders, would lose jurisdiction over management actions were Bebchuk and Ferrell's normative position favoring national takeover regulation adopted.

A closing important point needs to be made regarding state competition, national (noncompetitive)

the substantive result nor would its more recent interpretations of the Unocal standard indicate otherwise. The Court has adopted the standard that a defense cannot be "preclusive" of a bid, see Unitrin, Inc. v. Am. Gen. Corp., 651A.2d 1361 (Del. 1995), and the Chancery Court in Interco found the failure to redeem the pill in that case was preclusive of the bid.

${ }^{425}$ See, e.g., Chesapeake Corp. v. Shore, 2000 Del. Ch. LEXIS 20 (Del. Ch. Feb. 11, 2000) (striking down a bylaw amendment that required supermajority vote of shareholders to amend bylaws); Blasius Indus. v. Atlas Corp., 564 A.2d 651 (Del. Ch. 1988) (striking down bylaw amendments that impaired consent solicitation); Quickturn Design Sys. v. Mentor Graphics Corp., 721 A.2d 1281 (Del. 1998) (striking down deadhand pill that impaired proxy fight); Carmody v. Toll Bros., 723 A.2d 1180 (Del. Ch. 1998) (same). It should further be noted that the Delaware courts, notwithstanding Bebchuk and Ferrell's contention, see Bebchuk \& Ferrell, supra note 180, at 1179, do not unambiguously permit a "Just say no defense." In both of the cases that they cite for this proposition, although the efficacy of management's action can certainly be debated, the target management had proposed an alternative plan to the hostile bid, a merger in one case and a stock repurchase in the other. See Paramount Communications, Inc., 571 A.2d 1140 (merger); Unitrin, 651 A.2d 1631 (stock repurchase plan). Moreover, even if they are correct regarding court approval of a "Just say no" defense, in practice this is not a viable strategy for management. Shareholders who lose out on a substantial premium and receive no cash payment (as in a stock repurchase defense) or follow-up bid are disgruntled investors who can make life difficult for managers, especially as it is understood that they will be receptive to opposition to management proposals, including director nominees. Even Martin Lipton, a prominent takeover lawyer, who interprets the Delaware decisions as permitting a "Just say no" defense, recognizes that such a defense is not likely to be available in practice, Martin Lipton, Takeover Response Checklist, 72 Aspen L. \& Bus. 1, 6 (Jun. 1, 2001); hence it is difficult to view such action by the court as significant evidence for construction of a case against competition. Bebchuk and Ferrell's final criticism of the Delaware courts, as creating undue uncertainty over takeover law, is derived from Ehud Kamar's more general thesis regarding Delaware law, which was critiqued in supra Part IV.C.2.

${ }^{426}$ See, e.g., Invacare Corp. v. Healthdyne Techs. Inc., 968 F. Supp. 1578 (N.D. Ga. 1997) (upholding deadhand pill under Georgia law); Amp Inc. v. Allied Signal Inc., 1998 U.S. Dist. LEXIS 15617 (E.D. Pa. Oct. 8, 1998) (upholding deadhand pill under Pennsylvania law). 
regulation, and Bebchuk and Ferrell's critique. If Bebchuk and Ferrell are correct and takeover statutes are paradigmatic of the output of state competition, that is, that it is a system of corporate law rules that enables management to exploit shareholders, then besides their explanation's inconsistency with the empirical literature on competition (positive findings of event studies of reincorporations and comparative work on Delaware firms' performance), it is difficult to explain the most salient features of comparative corporate governance in which the United States excels over virtually all other regimes. Not only are U.S. capital markets the thickest in the world, but also U.S. corporations have the most dispersed shareholder base, they operate under corporate laws with greater protection of public and minority shareholders, and are subject to more takeovers, compared to corporations in any other country. ${ }^{427}$ In addition, cross-country data further suggest that improved allocation of capital (a real economy effect) is positively related to shareholder protection under corporate law and the extent of capital market development. ${ }^{428}$ State competition for corporate charters is the most distinguishing feature of the U.S. legal regime, which has produced such large benefits for investors, as all other countries except Canada and Australia have national corporate law systems, and those two countries do not have charter competition. ${ }^{429}$ The existence of the SEC cannot explain these facts. The dominance of U.S. capital markets as the largest and most liquid equity markets predated the creation of the SEC. Moreover, the empirical literature finds an absence of value added by what the agency has done. The comparative governance data are undisputed, and they cannot be squared with Bebchuk and Ferrell's gloomy assessment of state competition.

\section{CONCLUSION}

This paper has maintained that international securities regulation should be opened up to jurisdictional competition, in which issuers choose a statutory domicile for securities law purposes whose rules will govern all the issuers' securities relations with investors regardless of where the investors are located or the shares traded. Such a

${ }^{427}$ See, e.g., La Porta et al., supra note 64; La Porta et al., supra note 66. The United Kingdom does as well as the United States in these comparative studies, suggesting that an important source for cross-country discrepancies is the common law tradition. A distinguishing feature of the common law tradition, compared to that of civil law, is its decentralized political tradition of limited government, see, e.g., Paul G. Mahoney, The Common Law and Economic Growth: Hayek Might Be Right, 30 J. Leg. Stud. 503 (2001); the U.S. corporate law regime epitomizes that tradition. It should further be noted that while LaPorta et al. stress the similarities in market depth and ownership structure between the United States and United Kingdom, British scholars have emphasized the differences in legal institutions and the timing of the dispersion of stock ownership across the two nations, see, e.g., Brian Cheffrins, Does Law Matter? The Separation of Ownership and Control in the United Kingdom, 30 J. Leg. Stud. 459 (2001). Cheffrins suggests that private organizations in the United Kingdom fulfilled the role played by the legal system in the United States during the $19^{\text {th }}$ and early $20^{\text {th }}$ centuries, institutions whose decentralized structure, in contrast to the national corporation statute, might have approximated the competitiveness of the U.S. charter market.

${ }^{428}$ See Jeffrey Wurgler, Financial Markets and the Allocation of Capital, 58 J. Fin. Econ. 187 (2000).

${ }^{429}$ See Romano, supra note 22, at 122-28 (discussing why charter competition has not emerged in the 
regime would be superior to the existing territorially-based system, for it would better track investor preferences and provide regulators with increased incentives to revise their regulations when they have fallen out-of-step with investor needs. It would, no doubt, take considerable effort to craft the multilateral accords necessary to achieve full implementation of international regulatory competition, but with the growing use of electronic trading, geographic boundaries are increasingly becoming obsolete as a source of regulatory authority and issuer domicile has become the most feasible alternative jurisdictional basis.

The proposal for regulatory competition advocated in this paper will undoubtedly have the greatest implications for non-U.S. is suers, who would be able to access the U.S. capital market without having to comply with SEC requirements, although some of these firms may, for a variety of reasons, including committing to subscribe to higher disclosure levels than required by the home regulator, still choose to opt into the U.S. regime. This is because in contrast to foreign issuers, U.S. issuers have already incurred the start-up costs of complying with the more elaborate SEC requirements and thus they would experience a more limited savings from experimenting with another jurisdiction offering a more refined set of disclosure requirements. However, if the SEC's disclosure regime is not cost justified, as the data suggest, a competing regulator will emerge, from among the fifty U.S. states or other nations, with a superior regime that will attract not only non-U.S. and new U.S. issuers, who have not yet incurred the start-up costs of SEC compliance, but eventually the mature issuers as well, who are competing for capital with new issues. This is the central lesson to be drawn from the evidence of responsive state behavior in the U.S. charter market.

Critics of regulatory competition in securities law have contended that it will lead to a race to the bottom, with firms rushing to register in states with the lowest disclosure requirements, or that it will result in a socially sub-optimal disclosure level because corporate information of a proprietary nature entails interfirm externalities and will not be disclosed voluntarily. As this paper has contended, the parade of horribles is unsupported and unsupportable. First, evidence from institutional equity and debt markets, as well as cross-country listing practices indicate that the voluntary disclosure choices of firms are frequently higher than mandatory requirements. When competition has been permitted in sectors of the securities markets and in corporate law in the United States, we have not found firms opting for minimum disclosure regimes or for states whose corporation law permits the exploitation of investors, and there is no plausible reason to expect any different behavior under full international securities regulatory competition.

Second, there is no evidence that the focus of SEC disclosure requirements, or their implementation by issuers, entails the revelation of information bearing on interfirm externalities nor could such a mandate be feasible:

Canadian context). 
firms would either find a way not to disclose proprietary information or they would exit from the regime by going private. A prime illustration is the business segment reporting requirements, which are typically considered to be an exemplar of interfirm externalities disclosure. These requirements provide great leeway to firms in the allocation of costs across segments and the definition of business lines, such that the disclosures are not especially informative: there was, for example, no price effect when firms began disclosing the data. Moreover, the formal models of disclosure regulation in the presence of interfirm externalities suggest that it would be difficult, if not impossible, for a regulator to ascertain the appropriate disclosure requirements that would increase, rather than decrease, social welfare. Finally, if investors, rather than issuers, are the selectors of the disclosure regime, as would occur under competition, then the problem of interfirm externalities is mitigated because the majority of shareholders are large institutions who hold portfolios of many firms and would therefore be able to internalize the costs and benefits of such disclosures.

Other critiques of regulatory competition based on a positive interpretation of the empirical literature on the effect of the federal securities laws, and a negative interpretation of state charter competition, upon investor welfare are inapposite. The best available evidence on the U.S. federal securities laws indicates that the SEC's regime has not been particularly effective, as its expansions of disclosure requirements have not had a significant positive impact on investor wealth. In my view, the data decisively trump the presumption conventionally accorded to the status quo (the SEC's exclusive jurisdiction over U.S. securities transactions). In addition, the evidence on the U.S. charter market indicates that state competition has benefited investors. This experience provides a benchmark for projecting what would be the most likely outcome under a competitive system of international securities regulation: investors would reap the benefit of improved incentives for entrepreneurs and regulators to select regimes that maximize share value.

\section{CODA: REPLY TO Fox II}

Merritt Fox has written another paper responding to my position in support of regulatory competition. ${ }^{430}$ Much of Fox's paper is a restatement of the arguments he made in his prior publications, ${ }^{431}$ to which this paper has responded. Accordingly, in this coda, I have chosen to address only the new arguments presented in Fox's

${ }^{430}$ Merritt Fox, The Issuer Choice Debate (unpublished manuscript 2001).

${ }^{431}$ Fox, supra note 3. For example, Part III.A.1. of Fox, $i d$., on the Dye model of disclosure regulation is nearly identical to his earlier article's criticism of the model; this will be evident to any reader who rereads supra Part III.B.1 of this paper after reading Part III.A.1. of Fox, $i d$., and Fox, supra note 3. This is also true of the discussion of segment reporting in Part III.C.3 of Fox, supra note 430, and the contentions in Part IV of Fox, id., regarding the significance of a change in variance of stock returns, the inappropriateness of examining stock prices to determine the impact of the 1933 Act, and the probative content of stock exchange manuals and an article by SEC attorneys on disclosure practices for assessing George Benston's finding that the 1934 Act had no effect on stock prices. 
paper. $^{432}$

It bears noting, however, that in his response, Fox still does not provide a scintilla of data for his claim that the SEC's mandatory disclosure regime has a connection to his rationale for its position as the sole securities regulator-the disclosure of interfirm externalities. There is a straightforward explanation for this omission: no evidence is provided in support of such a regulatory rationale because none exists. As I have detailed in this paper, the SEC does not perceive its regulatory objective to assist firms' competitors nor did Congress so perceive its objective when it assigned the SEC the task of implementing a securities disclosure regime. Congress located the federal regulatory regime for concerns regarding competition in the domain of the Antitrust Division of the Justice Department and the Federal Trade Commission, and not in its national securities disclosure policy.

\section{A. Are the Effects on Competitors of Interfirm Externality Disclosures Only Positive?}

In repeating his claim that information relating to interfirm externalities can only have positive effects on competitor firms, Fox criticizes an example that I provide of a disclosure that is a negative externality for competitors, regarding a patent for a new product: he contends that the example "involves no negative externality" because it "confuses" the "act" and "fact" "of disclosure" and will "lead to a positive externality." 433 I selected this example because it is a disclosure that the SEC currently permits firms to exclude from their filings for protection of proprietary information-information regarding the development of new products and lines of business $^{434}$-and therefore contains information that the SEC believes would involve interfirm externalities. In a footnote, Fox repeats the criticism distinguishing the "act" and "fact" of disclosure for my second example of a negative externality, a firm's disclosure of plans to expand plant capacity, ${ }^{435}$ as well. It should be noted that I

${ }^{432}$ Fox's response also contains several claims that he has not made specific arguments that I attribute to him. See, e.g., Fox, supra note 430, nn.5, 7-9, 11. Conscientious readers who review Fox's prior publications at the pages that I cite in the footnotes in this paper, in conjunction with my discussion in the text accompanying those footnotes, will be able to determine for themselves whether my characterization of his position is accurate. In reviewing Fox's objections to my references to his position, I found one reference that was incorrect, which involved his citation of an article by John Coffee, on institutional investors and portfolio diversification and I have corrected it: my discussion in supra note 141 of his position on portfolio diversification now reflects that Fox was referring to Gilson and Black's textbook, and not Coffee's article.

${ }^{433}$ Fox, supra note 430, at 11.

${ }^{434}$ See supra note 151 and accompanying text.

${ }^{435}$ Fox, supra note 430, at 12 n.29. Fox further attempts to dismiss this example by asserting that a "private" firm would also make the disclosure and hence it is "not relevant." This objection regarding what a nonregulated firm would do is beside the point. Rather, the example is relevant because if the government mandates disclosure of information regarding new business plans and products under Fox's rationale of mandating disclosure to assist competitors, it will not be able to determine a priori whether the information so disclosed will entail positive or negative externalities and, hence, whether its mandate will improve social welfare. Moreover, despite Fox's claim that both private and public firms will disclose the information, because a private firm is not subject to the SEC's antifraud regime, revelation of expansion plans by such a firm will not have the same credibility with competitors as a similar 
specifically selected this additional example because Fox previously identified as a relevant disclosure related to interfirm externalities the disclosure of a firm's "future capital spending plans, ${ }^{, 436}$ and he further asserted that disclosure of such information would "seriously hurt the issuer through the advantages it confers on other firms"- that is, that such disclosures only entail positive externalities. Confronted with the illustration of such a disclosure's possible negative effect, he now suggests that example he cited of a relevant disclosure is not actually what he meant.

The objection Fox directs to both examples of the patent and plant expansion is that the disclosures in question merely affect the timing of the negative externality - that is, he contends that the cash flow declines for competitors that follow these disclosures would inevitably occur were no disclosure made, because the decline is due to the substance of the disclosure (the patent or the expansion) and not the disclosure itself. Hence, in Fox's view, this means that the disclosure itself does not entail a negative externality. This criticism is without merit. First, Fox's contention of the inevitability of the cash-flow decline, independent of the disclosure, is not necessarily the case for the proposed plant expansion example. If the disclosure is made to deter entry that would otherwise be profitable, in the absence of the disclosure, the competitors would enter the market, conduct that might alter the profitability of the firm's expansion plans as well as the competitors' investments, and the cashflow effects might therefore differ from those that occur if the disclosure of the proposed expansion is made before the rival firms' investments. This difference between the examples may explain why Fox directs his text's attention at the patent example and places his criticism of the expansion example in a footnote. He also acknowledges in his footnote that the consequence for social welfare of the disclosure in the proposed plant expansion example "may be" negative. ${ }^{437}$ This recognition undermines his contention regarding the uniform direction of the price effects of disclosed interfirm externalities - that they always increase social welfare —which is the foundation for his critique of regulatory competition.

Second, the timing of a disclosure is typically the entire ball game with respect to competitive effects, which are the crucial effects from the perspective of Fox's interfirm externalities rationale for disclosure mandated by a single regulator. For example, accountants who are sympathetic to Fox's view of the efficacy of a disclosure regime that enhances competition state that:

The key factor in determining whether information ... creates competitive disadvantage is timing. Products in development eventually come to market. Strategies become obvious from actions, and information about them can then no longer lead to competitive disadvantage. At some age disclosure simply loses its capacity to create competitive disadvantage. A given category of disclosure can be competitively disadvantageous or competitively meaningless depending on when the disclosure is

disclosure when made by a publicly-traded firm, see Kahan, supra note 117, and thus may well not be disclosed.

${ }^{436}$ Fox, supra note 3 , at 1354.

${ }^{437}$ Fox, supra note 430 , at 12 n.29. 
made. $^{438}$

This is true of information entailing either a positive or a negative externality. To use the example in Part III.B.1.d. of this paper of disclosure of a proposed plant expansion, if, for instance, the firm does not disclose its plans for a significant expansion of capacity in advance of the undertaking, competitors may make additional plant investments and the profitability of all firms' investment strategies are likely to be different from what they would have been were the expansion plans disclosed in advance. Similarly, firms' research and development activities will be affected by their knowledge of the presence or absence of a rival's patent successes, and hence there will be real cash flow effects from the timing of the disclosure of a patent that do not depend simply on the patent's presence, as Fox presumes.

Consider, moreover, information that Fox would presumably distinguish from a patent, information regarding the extent of a firm's revenues or cost margins (its monopoly profits) revealed by segment reporting, the disclosure of which Fox has previously asserted involves positive interfirm externalities, ${ }^{439}$ and which should thus induce new entrants into the discloser's business. This disclosure is not subject to Fox's distinction between "act" and "fact," because (at least according to Fox) the firm's rivals or potential competitors will never obtain the precise information regarding the firm's rents without the segment reporting disclosure. Notwithstanding the segment revenue disclosure example's avoidance of Fox's "act" and "fact" distinction, this disclosure entails the identical structure for which Fox criticizes the paper's examples: the disclosure's impact on firm cash flows is, at best, only a timing effect. This is because competitors can observe indirectly abnormal profits accruing to firms by means of observing dominant market shares. Assuming no barrier to entry (which must be the case for Fox's rationale regarding the disclosure of interfirm externalities to be able to benefit competitors- they must be able to enter into the business that a firm's disclosure indicates is profitable), rivals will eventually enter the industry until the rate of return is normal; the segment reporting disclosure will only accelerate such entry. From the point of view of any particular firm, however, the timing of entry—and hence the timing of disclosure-may well make the difference between the firm's individual profitability or loss.

The segment revenue example suggests that Fox's distinction between the "act" and "fact" of disclosure,

${ }^{438}$ Robert K. Elliott \& Peter D. Jacobson, Costs and Benefits of Business Information Disclosure, 8 Acct. Horizons 80 (1994) (emphasis added). The three categories of business information that they consider to have potential competitive disadvantages and therefore are identical to Fox's category of interfirm externalities (disclosures that benefit competitors while harming the discloser) are "information about technological and managerial innovation," "strategies, plans and tactics," and "information about operations." The examples that Fox criticizes regarding new products and expansion plans fall into Elliott and Jacobson's first and second categories, and examples that Fox would appear to prefer, which I noted in the paper and discuss more fully in this response, fall into their last category.

${ }^{439}$ Fox, supra note 3, at 1354 ("examples [of disclosures with positive interfirm externalities] include profits 
which is his sole objection to the examples in the paper as illustrations of negative externalities, is neither as clean, nor as critical, as it might appear, for the primary impact on competitors of proprietary disclosures is one of timing. This is inherent in the nature of the disclosure process. Namely, one cannot in many, if not most, cases meaningfully distinguish between the impact on other firms of a firm's "act" of disclosing private information and the substance of the disclosure. For Fox's distinction to have force, capital markets would have to be strongform efficient, such that private information is impounded in stock prices prior to its public disclosure. The best available data indicate that this is not the case: only public information is incorporated into stock prices. ${ }^{440}$

Fox further uses his distinction between the "act" and "fact" of disclosure to assert that the patent disclosure is not a negative externality because the "act" of disclosure, despite its "obviously reduc[ing] the share values of [the firm's] competitors," will likely lead to a "positive externality" (that is, it will have a positive effect on competitors), as it will make them know "sooner what they will be facing in the future." twists the definition of a positive externality to include any conceivable information and price effect, including a negative effect. But the definition of a positive externality is disclosure of information that increases the cash flows of another firm, and not information that decreases those cash flows. The rivals may "get out" of the business "sooner" because of the patent disclosure, so that their losses may be lower than they might have been with no disclosure, but they are still experiencing a decline in cash flow from the disclosure. This is, by definition, a negative externality. Fox's characterization of the example of disclosure of a patent as a positive, and not a negative, externality for rival firms, to put it mildly, renders the concept of a positive externality meaningless. It is also at odds with his criticism that a disclosure whose significance is simply the timing of the information's release is not an externality. If the disclosure has the supposed positive impact of making competitors "get out [of the business] sooner" than they would have in the absence of the disclosure, then the impact of the disclosure is an effect of the timing of the disclosure and not of the disclosed information itself.

But even if one accepts Fox's objection to the patent and plant expansion examples, I could just as easily have provided an example of information generating a negative externality that cannot be characterized as due to the "act," as opposed to the "fact," of disclosure. A good illustration is the disclosure of a firm's operating costs, or profit margins, the impetus behind segment reporting requirements. Fox believes such disclosures will necessarily produce a positive externality that will encourage competitors to enter as they are informed of profitable opportunities, since he claims that all corporate disclosures have "at least some positive externality" that

and sales of each significant individual line of business conducted by the issuer").

${ }^{440}$ See, e.g., Ross et al., supra note 6, at 324, 328-35.

${ }^{441}$ Fox, supra note 430 , at 12. 
“can help competitors" $" 42$ and has specifically identified "profit margins" from segment reporting information as an example of the disclosures of concern to him. ${ }^{443}$ He does not, however, offer any rationale for his contention that the effect of such disclosures is one-sided.

In fact, contrary to Fox's position, disclosure about a firm's cost of operations or profit may very well indicate the strength of the firm's cost advantage, or the weakness of the market in which it operates, information that, in contrast to the examples in Part III.B.1.d. of this paper, is not likely to be disclosed voluntarily in order to preempt competition. Such line of business disclosures, will, however, adversely affect current and potential competitors, because the disclosure will discourage firms from entering and reduce existing rivals' stock prices and their access to capital, as their investors realize their internal rates of return are lower than expected or than their rivals'. In such a circumstance, the information regarding the cost or profitability of the line of business has a negative, not a positive, impact on the rival firms' cash flows, as it pushes them out of, not into, the business line. The disclosures thus constitute a negative, and not a positive, externality. Fox's hypothesis that disclosing information regarding a firm's profit margins can only increase its competitors' cash flows is plainly mistaken.

Fox's intuition is undoubtedly correct that detailed information about costs is not likely to be disclosed voluntarily. This is because investors are interested in predicting a firm's future cash flows, while competitors are not, ${ }^{444}$ and information of relevance to competitors will only be disclosed when there is an overlap between the two groups' information demands, that is, when information that meets investors' needs coincides with information of use to competitors. Competitors have a pretty good idea regarding rivals' revenues from their own revenue information, as well as their access to data on market shares, and hence, in contrast to investors, they would benefit from more precise cost, not revenue, disclosure. But for cash flow estimation, greater precision in revenue information serves as well as more precise cost information, and hence firms can satisfy investors' disclosure needs in this regard without assisting competitors. According to Fox's rationale for a mandatory disclosure regime, then, precise cost, rather than revenue, disclosures should be required. This is, however, emphatically not the current regime, which is what Fox claims to be rationalizing. In 1997, for example, the FASB amended its segment reporting rules, going beyond the SEC's requirements, in order to render the disclosure more informative, but at odds with Fox's rationale and consistent with my critique of it, the mandates were directed at more precise disclosure of revenue, not cost, information. ${ }^{445}$

\footnotetext{
${ }^{442} I d$. at 35.

${ }^{443}$ Fox, supra note 3 , at 1354.

${ }^{444}$ See Elliott \& Jacobson, supra note 438.

${ }^{445}$ Financial Accounting Standards Bd., Statement of Financial Accounting Standards Statement No. 131: Disclosures about Segments of an Enterprise and Related Information (June 1997). In contrast to the SEC's categorical segment reporting requirements, which the prior FASB standard had followed, SFAS No. 131 requires
} 
The FASB's action on the segment reporting rule underscores my criticism of Fox's position: the focus of the regime is not directed at requiring firms to disclose information of relevance to competitors. The issue of what information would be disclosed under regulatory competition entails a different inquiry, however, because, as discussed in Part III.B.2. of this paper and more briefly in this coda, when diversified investors choose the disclosure regime, if Fox is correct and there are net benefits from disclosing proprietary information, then those investors can seek its disclosure, since they will hold shares in numerous firms and will thereby share in the benefits of disclosures that accrue to a firm's competitors, and in contrast to the present state of affairs, firms that choose to continue to operate under a regime in which they do not make such disclosures would face a higher cost of capital.

\section{B. The Impact of Diversified Investors on Fox's Rationale for a Single Regulator}

Fox contends in his latest paper that institutional investors will internalize the costs and benefits of disclosing interfirm externalities (which means that a single regulator is not necessary under his rationale for disclosure regulation) only if "every investor" in the economy is an "index investor" holding the "same percentage of each issuer as every other investor does" in its portfolio. ${ }^{446}$ This contention is mistaken. Under regulatory competition, the disclosure regime will be selected by the marginal, informed investor. Because the majority of investors in equity are diversified institutions, and not the individuals whose portfolios, as Fox contends, are often not indexed, institutional investors have the highest probability of being the marginal investors whose disclosure preferences will dictate the choice of securities regime.

firms to report segment information the way they internally account for it. The change was promoted by financial analysts, who found the prior reporting inadequate because the reported segment data were typically unrelated to management's discussion of business operations, which reflected their internal data. E.g., Michael Ettredge et al., The Effect of SFAS No. 131 on Numbers of Reported Business Segments 5 (2000) (unpublished manuscript). Consistent with Fox's view and his depiction of his clients' concerns while in practice, corporations opposed changing the segment reporting requirements, voicing concern that more disclosure could be "competitively harmful." But what was the actual impact of the rule change on actual disclosure practices? Ettredge et al. examine whether the revision lived up to analysts' expectations, that is, whether it increased the number of segments reported by firms that could previously exploit the vagueness of the segment definition by lumping together dissimilar lines (the expected adaptive strategy, noted by Kitch, discussed in this paper at supra notes 173-74 and accompanying text). They find that the new standard was minimally successful in achieving its goal, as it resulted in a barely detectable increase in the number of reported segments. Ettredge et al., supra, at 22. In addition, firms in more concentrated industries reported a smaller increase (larger decrease) in the number of segments. $I d$. at 20 . To the extent that firms in less competitive industries are more likely to have monopoly profits, one would expect them to experience a greater competitive disadvantage from detailed segment disclosure. These findings bolster the cogency of Kitch's insight, which I emphasized in supra Part III.B.3 of this paper, that Fox's regulatory goal is futile: whatever their complaints to regulators regarding the impact of proposed disclosure requirements, companies will successfully go to great lengths to avoid disclosing proprietary information that adversely impacts them.

${ }^{446}$ Fox, supra note 430 , at 32. 
Just as Fox agrees that not all investors need to be informed for stock prices to be efficient, not all investors must hold shares in all firms for a competitive securities regime to include the disclosure of externalities: for a midstream choice, it depends on the holdings of the investor whose vote is pivotal, and for an initial choice, on the marginal investor in the public offering. Since the majority of shares are held by institutional funds, several of the largest of these funds are indexed, and even active stock pickers among institutions have holdings in numerous firms in the same sector (there are, for instance, numerous sector funds), it is most plausible to assume, without any data to suggest otherwise, that the decisive investor will be interested in the effects of disclosure policy on many firms besides just the issuer, that is, that it will consider the effect of disclosing interfirm externalities in its regime choice. ${ }^{447}$

Moreover, I raised the presence of institutional investors to make a straightforward point that Fox overlooks: even were we to accept Fox's rationale for mandating disclosure, it would still not be a self-evident justification for a single regulator. It is so only if the decisive investor is undiversified, such that its choice is equivalent to that of an issuer, which considers only the private costs and benefits of a disclosure policy. But given the composition of equity investors, the marginal investor in the vast majority of publicly traded firms will be a diversified institution. Fox offers no evidence that the marginal investor will not consider the effect of a disclosure policy on all of its holdings, and thus, if positive interfirm externalities outweigh negative ones, as Fox maintains, the marginal investor will prefer a regime that requires the disclosure of such information. ${ }^{448}$

${ }^{447}$ This point regarding the interests of diversified shareholders holds equally for IPO investments. Fox still misunderstands this point, as he repeats once again, $i d$. at 28-30, the objection in his earlier article that the investors in an IPO will not consider the impact of a disclosure regime on all of their investments and therefore will not require the new issue to submit to the disclosure regime directed at externalities that Fox contemplates. If interfirm externalities are only positive as Fox contends, then diversified institutional investors will insist that all firms in which they invest, including new issues, be registered under regimes that require the disclosure of such information. As the point is rather straightforward, Fox's repeated objection that IPO investors will consider the firm's disclosures in isolation of all other investments may be due to his oversight of the fact that the disclosure regime that the IPO firm chooses will continue to regulate its ongoing disclosures when the shares trade in the secondary market after the offering concludes.

${ }^{448}$ Fox notes in support of his objection that the proxy proposals of activist institutional investors are firmspecific and not directed at policies intended to enhance the value of all firms, $i d$. at 33. This objection is off the mark. Shareholder proposals brought by these public pension funds are expressly directed at improving the value of the targeted firm. See Roberta Romano, Less Is More: Making Institutional Investor Activism a Valuable Mechanism of Corporate Governance, 18 Yale J. Reg. 174 (2001). The decision of investors with regard to what shareholder proposal to make is thus not interchangeable with the decision they would make regarding the optimal disclosure regime for their investments. Moreover, Fox's objection may well be wrong. Some commentators have contended, exactly contrary to Fox's assertion, that the proposals are in fact intended to have, and do have, spillover effects to boost the performance of the stock market overall and not simply specific firms, because the proposal proponents are indexed. See, e.g., Del Guercio \& Hawkins, supra note 141, at 300. They suggest that the publicity of undertaking such proposals is a strategic tool the activist funds exploit precisely for the purpose of obtaining spillover effectsthat is, the threat of publicity "might als o motivate other companies to proactively improve their corporate governance structures without being explicitly targeted"-and provide as evidence of an externality reports that 


\section{The Interfirm Externalities Rationale and Analyst Activity}

In trying to show that the SEC's disclosure polic y is, in fact, directed at disclosing interfirm externalities, Fox states that "analysts pour over SEC issuer disclosure filings as soon as they become available." ${ }^{\circ 49}$ This activity is not, however, evidence that SEC mandates reveal information of relevance to the profitability of competitors. Analysts examine a firm's filings to learn about the filing firm and not with the principal goal of learning about competitors. Fox's reference to analysts' use of filings is in response to my statement that firms' disclosures are generic and boilerplate with respect to information that would benefit competitors. Fox's citation of analysts, rather than rival firms, as the ones who use SEC filings for information proves my point rather than refutes it. Disclosures that do not reveal information to competitors, who have their own proprietary information about a business sector's revenues, may well provide information to outsiders, such as analysts, about the particular firm as well as its industry. ${ }^{450}$

In this regard, Fox's reference to the behavior of analysts bolsters Jonathan Macey's thesis regarding who benefits from the SEC's disclosure regime-market professionals rather than insiders, who would otherwise be well positioned to trade on private information against professionals. ${ }^{451}$ But Fox's rationale for the SEC disclosures in question, as well as his objection to regulatory competition, is not that the disclosures benefit analysts, but that they benefit competitors. ${ }^{452}$

CalPERS is contacted by non-targeted firms' managers in order to stay off their target list. Id. These anecdotes of spillover effects in the shareholder proposal context indicate that institutional investors consider the impact of their actions on more than one firm, which is all that is necessary for my point that the incentives of institutional investors differ from issuers regarding the content of a securities regime to be correct and Fox's criticism of it to be misplaced.

${ }^{449}$ Fox, supra note 430 , at 38.

${ }^{450}$ Fox makes another curious claim concerning analysts' use of data regarding the disclosure of depreciation after the 1934 Act: that despite depreciation's lack of bearing on real cash flows, its disclosure enabled analysts (and investors) to make "meaningful new inferences" about "cash flows" for the small set of firms not disclosing depreciation prior to the Act. Id. at 36. Notwithstanding Fox's assertion, disclosure of depreciation does not provide "meaningful new information" for predictions of cash flows, evidenced by the fact that accounting depreciation methods, as earlier noted, are not related to actual cash flows. See, e.g., Beaver \& Dukes, supra note 167. I know of no study, nor does Fox cite any, showing that stock prices are correlated with accounting depreciation, which would be the other type of empirical evidence that could support Fox's contention.

${ }^{451}$ See, e.g., Jonathan R. Macey, Insider Trading 68 (1991).

${ }^{452}$ As a consequence, Fox's response to my illustrations in supra Part III.B.3 of this paper that indicate the absence of information of significance to competitors in actual filings, that the type of information required to be disclosed in the SEC rules "would appear to be useful to competitors" and "suggest that some of the information ... is in fact useful to these other firms," Fox, supra note 430, at 38, undercuts, rather than bolsters, his position. This is because his position is that the rationale for a single regulator and the current mandatory disclosure regime is to disclose interfirm externalities, that is, to assist competitors, not investors. The possibility that the current regime might sometimes provide "some" information that "appears" to be "useful" to a competitor-Fox's response to my illustrations - contradicts his thesis, for it demonstrates that the mitigation of interfirm externalities is utterly tangential to the SEC's disclosure requirements and has little connection to the SEC's implementation of its 


\section{Fox's Objection to the Admati and Pfleiderer Model of Disclosure Regulation}

As discussed in Part III.B.1.e. of this paper, Admati and Pfleiderer model the mandatory disclosure of interfirm externalities and show that mandatory disclosure is not always a welfare improvement over voluntary disclosure even if the externality is always positive, despite Fox's presumption to the contrary. Fox contends that their model is not relevant because it is directed at disclosure of financial and not real externalities, in modeling the benefit of disclosure as "mak(ing) it possible for investors to make more accurate valuations of one or more other firms." ${ }^{453}$ Fox is incorrect; the model is relevant. Moreover, this objection to the model creates a serious analytical problem for Fox's position on regulatory competition. For much of his critique of regulatory competition is premised on the very features of the Admati and Pfleiderer model to which he is objecting.

In particular, Fox considers the SEC's line-of-business reporting requirement, as well as its adoption of a sales disclosure requirement following the 1934 Act, as examples of mandated interfirm externalities and he characterizes the empirical evidence that such disclosures reduced stock variances as demonstrating that the disclosures created "meaningful information as they made prices more accurate." that this is not evidence of disclosure of meaningful information because there was no stock price effect, which is the conventional definition for information to be considered meaningful for investors. ${ }^{455}$. But setting aside the interpretive disagreement between Fox and myself regarding that data, information that produces a change in the variance of stock returns without affecting the stock price does not involve a real externality-real externalities, by definition, affect firm cash flows and thus affect prices. Thus, such disclosures, at best, pertain to a financial externality. This is the very type of disclosure that Admati and Pfleiderer are modeling. Fox's view of the segment reporting and sales data, that they are exemplars of his concept of an interfirm externality that has been

regulatory function. If this were not the case and the SEC deemed its mission to be that which Fox ascribes to it, information of value to competitors would be the focus of firms' filings and not simply an occasional byproduct. In short, as the discussion in supra Part III.B.3 of this paper makes clear, there is no evidence that the SEC disclosure regime has as its function the rationale that Fox posits for it.

${ }^{453}$ Fox, supra note 430 , at 27.

${ }^{454} \mathrm{Id}$. at 35 .

${ }^{455}$ Fox introduces a further argument in his response regarding the insignificant stock price effects of the 1934 Act, that because the event study methodology cannot pick up an extremely minute price effect, the Act could have increased stock prices by $.05 \%$ without its identification by Benston. $I d$. at 59 . He contends that this speculation "devastates" the conclusion that the legislation did not affirmatively benefit investors, id., after he admits that "[t]he lack of statistical significance means that these results provide no affirmative evidence that the benefits from Exchange Act mandatory disclosure are greater than their costs," $i d$. at 58. Fox's speculation regarding a minuscule positive price effect of the 1934 disclosure mandates is nothing more than that, pure speculation. There is absolutely no basis for claiming that there was such a hypothesized effect, particularly as no study of any SEC disclosure mandate has ever identified a positive price effect. Fox is grasping at straws. It is simply implausible to maintain that every SEC mandate induced a price effect of no more than $.05 \%$, as against the more straightforward 
mandated by the SEC, is therefore identical to the disclosures in the Admati and Pfleiderer model, which he is now dismissing as irrelevant. He cannot have it both ways. Either a model of financial externalities is relevant to his position or the data on SEC disclosures do not support his position. More important, even if Fox were to adopt a consistent position on the relevance of the SEC disclosure data to his normative position regarding the import of real, as opposed to financial, externalities, the Admati and Pfleiderer model is still, in my judgment, highly relevant to the key issue in contention between Fox's position and regulatory competition - that is his claim that mandatory disclosure is always superior to voluntary disclosure-notwithstanding that they model financial rather than real externalities. Their model shows that in the context of financial externalities, Fox's absolutist position is mistaken: welfare can be decreased by a mandatory disclosure regime. There is no reason to believe that the ambiguity regarding the efficacy of government mandates would vanish were their model revised to impose real rather than financial externalities (that is, were a cash flow effect being modeled) and every reason to believe that the case against Fox's view would be increased. This is because the modeling of the impact of a real externality is more complex than a financial externality, and as the paper has discussed, the more complex the model, the more openended the analytical results become. It is instructive, although obviously not determinative, that they obtain the same result as the Dye model, which does depict real externalities (and whose simpler model of financial externalities produces a result of no difference between voluntary and mandatory disclosure, which also offers no support for Fox's position).

The same is true of the third model that I was recently able to locate of disclosure policy in the context of interfirm externalities. Suil Pae models whether mandatory disclosure regulation can improve social efficiency in the context of production decisions, in a market where demand is uncertain, consisting of duopolists who will not voluntarily disclose private demand or cost information. ${ }^{456}$ This is a model involving real externalities. In the absence of mandatory disclosure, the firms play a preemption game in which they decide whether to produce before or after they receive their private demand information (which is not disclosed). This decision is based on a trade-off between preempting the rival (obtaining a larger market share) and making a more informed output choice (conditioning output on demand), and the choice varies depending on two industry characteristics: the size of the market and the degree of uncertainty over demand. Mandatory disclosure alters the trade-off such that waiting for demand information is less attractive, and in equilibrium, the firms produce prior to the arrival of their private demand information, when they would have waited were disclosure not mandatory. As a consequence, expected profits and consumer surplus change, resulting in strictly lower payoffs than in the voluntary disclosure

explanation of the data, that the required disclosures provided no benefit to investors.

${ }^{456}$ Suil Pae, Information Sharing in the Presence of Preemptive Incentives: Economic Consequences of Mandatory Disclosure, 5 Rev. Acct. Stud. 331 (2000). 
equilibrium.

Mandatory disclosure in Pae's model—a Cournot market under demand uncertainty—-therefore may not achieve its intended purpose of improving social welfare; it will do so only under the restrictive condition that firms wait for their information to arrive in both voluntary and mandatory disclosure regimes. Because firms' incentives to wait under both regimes depend on the industry characteristics, Pae concludes, similar to the conclusions of Dye and of Admati and Pfleiderer, that there are very substantial information demands on regulators for the policy to work: "regulators must acquire sufficient information about those [industry] characteristics" if a mandatory disclosure is not to "run the risk of reducing social welfare. ${ }^{457}$ Like those other models, one can argue over the realism of Pae's model's assumptions. Moreover, Pae's model is far more stylized than the Dye and Admati and Pfleiderer models and has a structure less transferable to conventional securities disclosure settings given the duopoly market and type of disclosure that, in my judgment, limits its usefulness for evaluating the efficacy of a mandatory disclosure policy compared to the other two models. But there is a striking uniformity across the three models of disclosure in the context of interfirm externalities: all of the models indicate that mandatory disclosure regulation does not guarantee an increase in social welfare over that attained when disclosure is voluntary and, indeed, may well lower it.

\section{E. Does Fox's Interfirm Externalities Rationale for the Current Disclosure Regime Mesh with His Policy Recommendations for International Securities Regulation?}

Fox emphasizes throughout his latest paper, consistent with his prior work, that the purpose of securities regulation, the disclosure of information regarding interfirm externalities, is not to improve investors' financial decisions, but, rather, to enable competitors to make better decisions on the allocation of real assets. There are significant problems with this position, and I will note two beyond the obvious difficulties with the thesis already discussed in the paper, namely, that the SEC does not perceive its mission as policing issuers' competitors' decisions regarding the allocation of real assets, as opposed to assisting investors' decisions regarding the purchase and sale of financial assets, and thus in practice such disclosures are not required under the SEC's regime.

First, there is a mismatch of regulatory objective and the tools with which to implement it. Namely, if improved product market decisions are the purpose of the U.S. mandatory disclosure regime under the federal securities laws, then the wrong agency is administering the statute. Fox should be directing his advocacy efforts at having the administration of the securities laws transferred to the Federal Trade Commission, for it is surely

\footnotetext{
${ }^{457}$ Id. at 334.
} 
better positioned, given its administrative expertise, than the SEC to determine what will facilitate competition. In fact, during the 1970s, the FTC maintained its own segment reporting requirements, which differed from the SEC rules, to assist its efforts at policing anticompetitive behavior, a policy consistent with Fox's concerns, although the information was revealed solely to the agency and not to the rival firms. ${ }^{458}$

Second, Fox restricts his mandatory disclosure regime to domestic corporations, asserting that the bulk of firms' shareholders are domestic and national regulators can best choose the mandatory disclosure level for their countries. ${ }^{459}$ This regime not only entails regulatory competition of the worst possible sort, ${ }^{460}$ but it is a policy recommendation inconsistent with the logical implication of his analysis, which is the need for a mega-regulator at the global level. For under his analysis, the crucial capital allocation decisions depend on managers' (and possibly investors') being able to interpret accurately the significance of interfirm externality disclosures regarding competitors' disclosures on industry or sector profitability. Because firms' competitors in both product and capital markets include foreign, and not simply domestic, corporations, when disclosure regimes differ by nationality, not all firms obtain the necessary proprietary information about their rivals. In particular, some nationals will be advantaged over others, and the optimal real asset allocations that Fox anticipates will not be undertaken (because there will not be mandatory disclosure of all existing positive externalities). Fox's solution therefore will not achieve his stated objective of the efficient allocation of capital, and if his thesis is correct, his solution may well hinder it, given that it will increase the disclosure discrepancies across firms active in the same equity markets.

\section{F. Conclusion}

Fox concludes his response by stating that: (1) "the case that issuer choice will lead to market failure is overwhelming"; (2) that empirical studies of the securities laws provide "no affirmative empirical evidence in support of either proposition [that those laws increased or decreased social welfare]"; and (3) that I "should stop battling these hard facts."

Fox now apparently concedes that there is no empirical evidence that the federal securities laws increased

\footnotetext{
${ }^{458}$ The agency collected line-of-business data from 1974-1977, eventually publishing the data in aggregate form, keeping all firm-specific information confidential, and had in place strict confidentiality rules regarding the access and use of the data by agency employees. See, e.g., FTC Line of Business Program: Notice of the 1977 Annual Line of Business Report, 50 Fed. Reg. 29,482 (July 19, 1985); FTC Line of Business Reports Program: Revision of Confidentiality Rules and Procedures, 51 Fed. Reg. 12,743 (Apr. 15, 1986).

${ }^{459}$ Fox, supra note 13.

${ }^{460}$ As I mentioned in my prior article, regulatory competition restricted by a firm's geographical location introduces significant friction into interjurisdictional moves and therefore reduces the feedback regulators receive regarding desirable regulation from issuer inflows and outflows. Romano, supra note 2, at 2408-09.

${ }^{461}$ Fox, supra note 430, at 59.
} 
social welfare, while asserting that the data do not show those laws decreased social welfare. ${ }^{462}$ I have not maintained that the empirical literature decisively shows the federal regime decreased social welfare, but, rather, that it demonstrates the point that Fox now acknowledges, that the regime did not increase social welfare, and that a cogent and plausible case can be made that it decreased welfare because it requires disclosures, unrelated to interfirm externalities, which would not be undertaken by the market's cost-benefit calculation. In my view, this is more than sufficient for concluding that the status quo in securities regulation should not be privileged and that we should instead seek to introduce competition into this regulatory field, which is the norm in corporate law, the area most related to securities law because of their shared objective (at least according to nearly all commentators albeit not Fox), protection of the interests of investors. What I advocate regarding securities law reform is the working hypothesis in a capitalist economy - a preference for market solutions where there is no showing of externalities or, to be more precise, no showing of externalities that can be adequately mitigated by regulation.

Indeed, there is no justification, given Fox's interfirm externalities rationale, for Fox's own proposal that the SEC's mandates should apply solely to domestic issuers and not all issuers trading in the United States. It is, in fact, contradictory to have the securities regime vary with a firm's nationality and not territorially, if enhancing competitiveness through the disclosure of interfirm externalities is the goal of the securities regime. That is because foreign firms listing on U.S. exchanges compete in the same product and capital markets as domestic issuers, yet they would not have to disclose information regarding their own costs and profitability, thereby impeding the efficient capital allocation that is to be effectuated by the mandatory disclosure regime under Fox's analysis. ${ }^{463}$ It is similarly inconsistent for Fox to permit foreign issuers to continue to list on U.S.exchanges under the SEC's regulation and not their home regulator's, since according to his rationale, only the home regulator knows what is the appropriate disclosure level for its nationals, yet he would not prohibit such a choice. Fox's concluding assertion that "the much admired U.S. regime of mandatory disclosure should be retained" ${ }^{464}$ reflects a persistent mistake motivating his criticism of regulatory competition, which perhaps explains his implacable hostility to experimentation with a market-oriented approach to securities regulation for U.S. issuers. Namely, the implicit premise of this assertion is that without the SEC as the exclusive regulator of U.S. issuers, firms would engage in perfunctory disclosure, the content of which bears no resemblance to the existing regime. Regulatory competition would not eliminate all of the disclosure now required by the SEC nor, in all probability, many of the items that are the subject of the SEC mandates that Fox considers to be "much admired." The elements of the

${ }^{462} I d$. "The empirical studies on whether the imposition of the U.S. mandatory disclosure in the 1930s in fact led to an increase or decrease in social welfare provide no affirmative support of either proposition." (emphasis added).

${ }^{463}$ Fox, supra note 13.

${ }^{464}$ Fox, supra note 430 , at 59. 
SEC regime that investors deem valuable would continue to be disclosed. This is a core claim of both of my papers on regulatory competition, which have detailed the content of voluntary disclosure practices and the choices made under competition in corporate law, a setting similar, and integrally related, to securities law. What regulatory competition would eliminate is the SEC's regulatory monopoly over U.S. issuers (and non-U.S. issuers choosing to list on U.S. stock exchanges), and by doing so, it will facilitate implementation of the disclosure regime that investors value most highly. This distinction is at the heart of the difference between my policy proposal and that of Fox. 